Florida International University FIU Digital Commons

$10-17-2013$

\title{
Catholic Student Movements in Latin America: Cuba and Brazil, 1920s to 1960s
}

Joseph Holbrook

Florida International University, jholbroo@fiu.edu

DOI: $10.25148 /$ etd.FI13121206

Follow this and additional works at: https://digitalcommons.fiu.edu/etd

Part of the History of Religion Commons, and the Latin American History Commons

\section{Recommended Citation}

Holbrook, Joseph, "Catholic Student Movements in Latin America: Cuba and Brazil, 1920s to 1960s" (2013). FIU Electronic Theses and Dissertations. 1013.

https://digitalcommons.fiu.edu/etd/1013

This work is brought to you for free and open access by the University Graduate School at FIU Digital Commons. It has been accepted for inclusion in FIU Electronic Theses and Dissertations by an authorized administrator of FIU Digital Commons. For more information, please contact dcc@fiu.edu. 


\title{
FLORIDA INTERNATIONAL UNIVERSITY
}

\author{
Miami, Florida
}

\section{CATHOLIC STUDENT MOVEMENTS IN LATIN AMERICA: CUBA AND BRAZIL, 1920s TO 1960s}

\author{
A dissertation submitted in partial fulfillment of the \\ requirements for the degree of \\ DOCTOR OF PHILOSPHY \\ in \\ HISTORY \\ by \\ Joseph Holbrook
}

2013 
To: Dean Kenneth G. Furton

College of Arts and Sciences

This dissertation, written by Joseph Holbrook, and entitled Catholic Student Movements in Latin America: Cuba and Brazil, 1920s to 1960s, having been approved in respect to style and intellectual content, is referred to you for judgment.

We have read this dissertation and recommend that it be approved.

$\begin{array}{r}\hline \text { N. David Cook } \\ \hline \text { Aurora Morcillo } \\ \hline \text { Sha Maria Bidegain } \\ \hline \text { Sherry Johnson, Major Professor }\end{array}$

Date of Defense: October 17, 2013

The dissertation of Joseph Holbrook is approved.

Dean Kenneth G. Furton

College of Arts and Sciences

Dean Lakshmi N. Reddi

University Graduate School

Florida International University, 2013 
C Copyright 2013 by Joseph Holbrook

All rights reserved. 


\section{DEDICATION}

I dedicate this dissertation to the memory of my beloved wife and companion for

the journey, Debbie Holbrook. Without her patience, understanding, support, and most of all her love, the completion of this work would not have been possible. 


\section{ACKNOWLEDGMENTS}

I would like to express my deepest gratitude to my mentor and advisor, Dr. Sherry Johnson, for her constant guidance, encouragement and occasional well deserved rebukes which kept me on target and moving through the maze of writing, graduate studies, writing, bureaucratic negotiation and maneuvering, research, analysis and more writing. I thank her for her incredible patience, constant honesty, and perhaps most of all, her generosity and friendship.

I also want to thank the wonderful and dedicated members of my thesis committee, Dr. N. David Cook who gave me invaluable help in preparing for my qualifying exams and introduced me to the rich literature on Atlantic Civlization. Dr. Ana María Bidegain, who opened access to people and to archives without which this dissertation would never have been possible, and Dr. Aurora Mocillo, who helped me come to grips with theory and inspired my interest in the European background for my topic. I am also grateful to the Latin American and Caribbean Center (LACC) faculty and staff and, in particular, Mrs. María Ferrer-Young, for all of their help and support over the past seven years. I must also recognize the late Dr. Dow Robinson, who encouraged my early academic interest in Latin America. Appreciation must also be expressed to my dear friend Dr. Samuel Lopez de la Victoria, who gave me the initial kick in the pants to start graduate school, and who patiently listened to my complaints, concerns, anxieties, triumphs and defeats and helped encourage me to stay the course through the entire process. Many thanks to Dr. Mark Szchuman, who was most responsible for recruiting me into the department of history. 
The research for this dissertation was made possible by the Tinker Research Travel Grant for travel to Brazil, and a Cuban Research Institute grant that made possible travel to Cuba. Three semester of the Foreign Language Area Studies fellowship made possible my acquisition of Portuguese and for two summer scholarships for foreign language study in Brazil. I also wish to acknowledge the critical role that the Cuban Heritage Collection fellowship played in providing a fellowship which made it possible to study primary materials on Cuban history. My sincere thanks to the History Department, in particular Dr. Gywn Davies, and to the University Graduate School for providing a Documentary Evidence Acquisition (DEA) fellowship for two semesters to allow me to carry out interviews and gather additional documents necessary for this dissertation. An additional two semesters for writing, thanks to the Dissertation Year Fellowship (DYF), made it possible for me to finish the writing portion of this project.

Fellow graduate students, two of who are now professors, Dr. Erika Edwards, Dr. Julio Capo and Adam Silva patiently read through my chapters and gave me invaluable suggestions. Also the friendship of other graduate students (several of whom have since graduated and are now teaching in the academy) such as Dr. Amanda Snyder, Dr. Quinn Dauer, Dr. Loraine de la Fe and Melissa Armitage provided invaluable emotional support through the long and often tedious process, especially in the period around my wife's death. I must thank other friends outside of FIU as well, for their steadfast friendship and encouragement. These include Dan and Patti Crute, Phillip Rincon, Evelyn Borrel and Myriam Zayas. 
Finally, I must thank my wonderful children who became dear friends during my long journey of studying for a PhD while dealing with Debbie's terminal cancer. Sarah, Jessica, Ruth and John: thank you! 


\title{
ABSTRACT OF THE DISSERTATION \\ CATHOLIC STUDENT MOVEMENTS IN LATIN AMERICA: \\ CUBA AND BRAZIL, 1920s TO 1960s
}

\author{
by
}

Joseph Holbrook

Florida International University, 2013

Miami, Florida

\section{Professor Sherry Johnson, Major Professor}

This dissertation examines the ideological development of the Catholic Student movements in Cuba and Brazil from the 1920s to the 1960s. The dissertation will argue that there existed two different ideological currents of lay-led student movements within global Catholicism that were formed in contrasting geo-political contexts in Europe. These differing theological ideologies influenced the development of Catholic student movements in Latin America during a period of intense social and political change.

The dissertation compares and contrasts two case studies of Catholic student movements and their political and social roles in Cuba and Brazil. The experience of the student leaders led them to experience ideological tension and in some cases, rupture, with the conservative ideology of the Catholic hierarchy. The proliferation of student organizations became part of the ideological battlefield of the Cold War. Catholic university students also played key roles in the Cuban Revolution (1957-1959) and in the attempted political and social reforms in Brazil under President João Goulart (19611964). 
The Catholic student movements, under the guidance of the church hierarchy, attempted to avoid aligning with either ideological camp in the Cold War, but rather to chart a "third way" between materialistic capitalism and atheistic socialism. Thousands of students in over seventy nations were intensively trained to think critically about pressing social issues. The dissertation places the Catholic Student movements in Cuba and Brazil in the larger context of transnational Catholic university movements using archival evidence, interviews, newspaper accounts and secondary sources. Despite the hierarchy's attempt to use students in order to increase traditional Catholic influence in society, the actual lived experience of students equipped them to think critically about social issues, and helped lay a foundation for the Second Vatican Council (1962-1965) and the rise of liberation theology in the1970s. 


\section{TABLE OF CONTENTS}

CHAPTER

PAGE

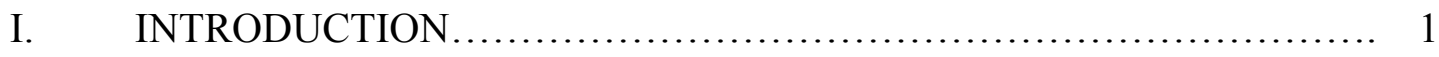

Literature Review.................................................. 6

Theoretical Framework................................................ 19

Research Design.................................................... 33

II. EUROPEAN ROOTS OF CATHOLIC ACTION, 1922-1939_............ 37

Catholic Action, the General Italian Model............................ 41

Catholic Action, the Specialized Franco-Belgian Model................... 58

Catholic Student and University Movements ........................... 66

Catholic Action moves from Europe to Cuba and Brazil.................. 69

III. TRANSNATIONAL STUDENT MOVEMENTS: 1946-1956............ 73

Transnational Catholic Student Movements........................... 76

National Catholic Student Movements: Cuba and Brazil .................. 90

Catholic Student Movements in Cuba: 1946-1953 .......................... 91

Catholic Student Movements in Brazil: 1946-1956....................... 100

IV. THE CATHOLIC STUDENT MOVEMENT IN CUBA: 1953-1962 ........ 117

Ideological formation and International Influences, 1953-1956............ 119

The Cuban Revolution, 1956-59 .......................................135

Crisis and Confrontation between Church and State, 1959-1961 .............145

V. THE CATHOLIC STUDENT MOVEMENT IN BRAZIL: 1956-1966_.....162

Ideological formation and International influences: 1956-1960_.......... 165

Reform or Revolution, 1961-1964_.............................. 186

Crisis and Military Repression, 1964-1966........................... 199

Post-JUC, Persecution and Resistance: 1967-1968....................... 206

VI. THE INFLUENCE OF THE CATHOLIC UNIVERSITY MOVEMENT 213

Closed Catholicism, 1920-1960 .........................................219

Religion and politics ........................................... 230

Brazil and Cuba .................................................... 240

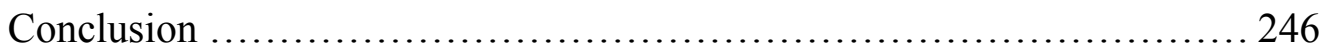

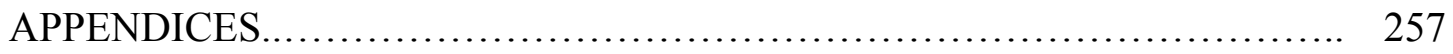

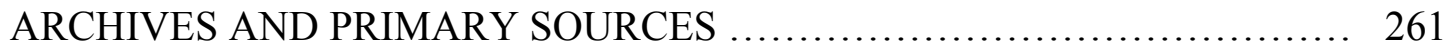

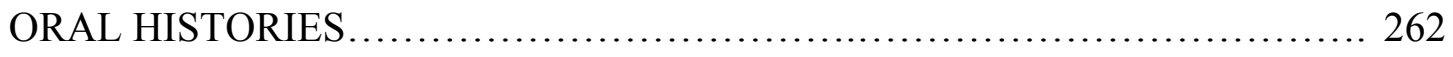

SECONDARY SOURCES................................................ 264 


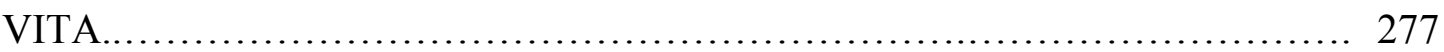




\section{CHAPTER I}

\section{INTRODUCTION}

My dissertation explores the relationship between Catholic university students and political reform in Brazil and Cuba from the 1920s through the 1960s. Brazil and Cuba offer many points of comparison by way of similar religious and cultural backgrounds but with contrasting political outcomes in the twenty years after the Second World War. By examining the role of Catholic students in attempts to bring about political reform or revolution in their respective countries, and by exploring their connections with various theological and ideological trends within international Catholicism this study will illuminate the role of youth in bringing about religious and political change.

The dissertation proposes that the Catholic hierarchy encouraged the development of the Catholic university student movement (Juventud Universitaria Católica or JUC) ${ }^{1}$ as a defensive institutional response to the growing secularization of the university environment and the consequent loss of influence by the church. It was also a strategic response by the hierarchy of the Catholic Church to the rapid expansion in the influence of university students in developing countries such as Brazil and Cuba. One unintended consequence of the relatively successfully integration of members of JUC into the professions and academic disciplines was the gradual politicization of Catholic student leaders as they engaged in intellectual dialogue with secular students and were exposed to

\footnotetext{
${ }^{1}$ In French speaking countries, the Catholic university organizations were called JEC: Jeunesse Catholique Etudiant (Young Catholic Students) whereas in Brazil and most of Latin America, "JEC" was only used to refer to the work among elementary and secondary students and JUC (Juventude Universitaria Catholica) (Catholic University Youth) was used to refer to the university organizations. In this dissertation, "JEC" will always be used to refer to secondary and elementary organizations unless specifically referring to university organizations in France, Belgium or Quebec. The primary focus here is on JUC: the university movements in Cuba and Brazil.
} 
their corresponding social and political theories. The effect of such interchanges was greatly enhanced by the socio-economic problems of Brazil and Cuba. The purposeful integration of religious faith with political action and the intentional insertion of militant Catholic students into secular academic spheres eventually brought the Catholic university youth into direct conflict with the state and the church hierarchy in Brazil and Cuba.

In the postwar period, activist university student movements expanded rapidly in Europe, North and South America and the Caribbean. In the politically polarized context of the Cold War, university student movements became a field of ideological contestation, in which Catholic student groups attempted to represent a "third way" between Marxism and Western capitalism. They simultaneously attempted to bridge the gulf between the church and secular society, and to regain influence in society on behalf of Catholicism through student and professional involvement at the grass roots level.

Two specific examples, Brazil and Cuba, have been selected as case studies to provide comparisons of the development of Catholic university student movements in Latin America. Cuba experienced a social revolution in 1959 in which many Catholic youth and university students actively participated. The Cuban Catholic hierarchy was caught in an ambivalent dilemma between support for the Cuban regime under the control of the corrupt Batista dictatorship on the one hand, and support for the impoverished and illiterate masses of Cuban peasants on the other. There was a growing emphasis among some Catholic theologians and philosophers and in certain currents within Catholic lay associations and religious orders on the importance of the "social teaching of the 
church." ${ }^{2}$ In addition, as the Cuban Revolution was in full swing in 1958, major changes within global Catholicism began with the death of Pope Pius XII (1876-1958) and the accession of John XXIII (1881-1963) to St. Peter's throne.

The Catholic student and university movement in Brazil during roughly the same time period as the Cuban case is a study in contrasts. The Brazilian students faced similar social and political issues as the Cuban students: severe social inequities, unstable national governments, encroaching secularism and rapidly expanding Protestantism posing a direct threat to the traditional Catholic religious monopoly. The Brazilian Catholic student movement rose to national prominence in the late 1950s and exercised significant political influence within the student movement and eventually within the presidential administration of João Goulart (1961-1964). ${ }^{3}$ The Brazilian Catholic university movement also became relatively prominent at the international level among transnational Catholic student movements elsewhere in Latin America and in Europe and left a progressive legacy that eventually influenced Liberation Theology. ${ }^{4}$

\footnotetext{
${ }^{2}$ The social teaching of the church is usually dated back to the encyclical Rerum Novarm (1891) of Leo XIII, in which the Pope attempted to address social issues regarding capital and labor from a Christian point of view. Although the encyclical supports the rights of workers to earn a living wage, it also supports the right to private ownership of property. Leo opposed the idea of class conflict and called for unity between classes. Pius XI (1857-1939) continued to develop the social teaching of the church in his encyclical Quadragesimo Ano in 1931. Pius XI was critical many aspects of modern capitalism while upholding the concept of private property. Nevertheless, property is also subject to the higher good, and the state had a right to pursue redistributive policies. The Pope condemned communism but also condemned the social conditions which gave rise to communism. He was less critical of moderate socialism but demanded that it distance itself from totalitarian communism and that it respect the dignity and freedom of the human person.

${ }^{3}$ José Oscar Beozzo, Cristãos Na Universidade e Na Política (Petrópolis: Editora Vozes, 1984), 46, 97.

${ }^{4}$ Milagros Peña, "Liberation Theology in Peru: An Analysis of the Role of Intellectuals in Social Movements," Journal for the Scientific Study of Religion 33.1 (March 1994): 39; Ana Maria Bidegain, "From Catholic Action to Liberation Theology: The Historical Process of Laity in Latin America in the
} 
The Brazilian and Cuban socio-cultural and religious colonial heritages had many similarities, although there were also some significant differences. In the nineteenth century, both Brazil and Cuba shared similar trajectories regarding slavery, abolition and economic dependence upon sugar monoculture. In the 1950s and early 1960s, both Brazil and Cuba shared the geo-political context of the intensifying Cold War between the United States and the Soviet Union. ${ }^{5}$

There are significant differences as well. Scholars such as Louis A. Pérez, Jr. have shown that Cuban culture and identity became inextricably bound with the United States because of the geographical proximity and cultural exchange. ${ }^{6}$ Brazil, on the other hand, was relatively removed from direct U.S. cultural influence. Cuban Catholicism was heavily influenced by the long tradition of the conservative and militant Spanish Catholicism while Portuguese Catholicism was never as militant in its crusading zeal nor was it as heavily influenced by Tridentine reforms of the sixteenth century. ${ }^{7}$

Twentieth Century," working paper, Kellogg Institute for International Studies, (Notre Dame, IN, 1985), 18.

${ }^{5}$ Another contrast between Brazil and Cuba was the process of gaining independence. Brazil managed to achieve independence from Portugal in 1821 without resorting to military conflict, Cuba's long delayed independence was influenced by the intervention of the United States in 1898.

${ }^{6}$ Louis A. Pérez Jr., On Becoming Cuban: Identity, Nationality, \& Culture (New York: Ecco Press, 1999), 231.

${ }^{7}$ The "Tridentine reforms" refers to the Catholic reforms initiated at the Council of Trent (15451563) also known as the Counter Reformation. Thomas Bruneau pointed out the religion that came from Portugal was not that of the Tridentine reforms but was an earlier form, medieval in character. "This process was abetted by a weak clergy, lack of organization, and a folk Catholicism based on a medieval, unreformed, and highly superstitious model which had evolved largely on its own during most of the colonial and empire periods": Thomas Bruneau, The Church in Brazil: The Politics of Religion (Austin, Texas: The University of Texas Press, 1982) 23-24; Mark Burkholder also observed that the Portuguese Church lacked the wealth and political power of the Spanish Church and that the "end of Muslim rule in Portugal in the thirteenth century gave the Church a history different from that of its Spanish counterpart." Mark A. Burkholder and Lyman L. Johnson, eds., Colonial Latin America, fifth ed. (Oxford and New York: Oxford University Press, 2004), 97. Regarding the poverty of the Portuguese colonial church, see C. 
The efforts of the Catholic university movements to bring reform to Brazil and Cuba resulted in some interesting paradoxes. The Catholic Church in Cuba appeared to be significantly more conservative than the Brazilian church. Although there were some socially progressive elements within Cuban Catholicism, the overall intellectual and ideological influences tended to be closely tied to traditional Spanish and Italian Catholicism. Nevertheless, Cuba experienced a social revolution which eventually pitted the church against the revolutionary regime, while in Brazil a political reaction emerged from military and economic elites that ultimately resulted in intense repression against progressive elements within the church and the student movements. Only after nearly twenty years of military rule did the semblance of political reform and democracy begin to emerge in Brazil. Despite the long delay, the Brazilian church was a significant partner in the process of democratic reforms. ${ }^{8}$

The Catholic university movement had the potential to be a modernizing influence within Brazilian and Cuban Catholicism and to contribute significantly to political and social reforms in their respective nations. However external transnational and ideological influences led the Brazilian and Cuban Catholic students down divergent paths. Serious internal ideological struggles existed within the respective university movements between the idealistic Catholic students and the more entrenched Catholic elites. At the same time, ideological tension existed within the respective national churches, arising

R. Boxer, The Church Militant and Iberian Expansion 1440-1770 (Baltimore, MD: Johns Hopkins University Press, 1978), 81.

${ }^{8}$ Joseph Holbrook, "Church, State and Political Culture in Brazil and Colombia," masters thesis (Green Library: Florida International University, 2006), 102. 
from the differing political and social contexts of each nation. In addition, each country developed along different historical paths. Brazilian Catholic students were strongly influenced by the example of the Cuban Revolution of 1959 and became even further radicalized while Cuban Catholic students almost immediately faced intense repression from the Left-revolutionary regime and consequently moved in a conservative, anti-Marxist direction. A few years later, the Brazilian church faced similar repression from a conservative military dictatorship causing the student movement to move even further to the left. $^{9}$

\section{Literature Review}

Scholarly analysis of the relationship between church and politics is multifaceted and complex. Nevertheless, as many scholars have shown, there is an intimate relationship between the historical legacy of the church and its institutions, and the political cultures and institutions of a given society. ${ }^{10}$ Daniel Levine, a noted scholar of church and politics in Andean region of South America, observed: "Their mutual centrality is not surprising. Politics, after all, deals at the most general level with the organizing principles and symbols of the entire society. Religion, in turn, provides values which give meaning to human life, placing any given set of social or political events in a broader framework of significance. $" 11$

\footnotetext{
${ }^{9}$ Kenneth P. Serbin, Secret Dialogues: Church-State Relations, Torture, and Social Justice in Authoritarian Brazil (Pittsburgh, PA: University of Pittsburgh Press, 2000), 221.

${ }^{10}$ For more on political cultures see Gabriel Almond and Sidney Verba, The Civic Culture: Political Attitudes and Democracy in Five Nations. London, UK: Sage Publications, 1989; Daniel J. Elazar, American Federalism; a View from the States. (New York: Crowell, 1972) and Joseph Holbrook, "Church, State and Political Culture in Brazil and Colombia." Masters thesis. Green Library: Florida International University, 2006.

${ }^{11}$ Daniel H. Levine, Churches and Politics in Latin America (Beverly Hills, CA: Sage, 1980), 35.
} 
Religion and politics have been closely intertwined in Latin America since the conquest of the Americas and even earlier in the eight-hundred-year Reconquista of the Iberian Peninsula. Religion was a central aspect of the development of Spanish institutions and social processes. Nevertheless, as Levine observed, the historical relationship between the political and the religious spheres underwent a "profound transformation" in the second half of the twentieth century. ${ }^{12}$

In contrast to North America, where religious pluralism and separation of church and state were the norm from the early constitutional period of national development, traditional Catholicism in Latin America was hegemonic and monopolistic. ${ }^{13}$ Latin American elites who desired to initiate political changes in the nineteenth century found religion to be an obstacle to liberal reforms. By way of contrast, Latin American conservatives looked to the Iberian Catholic heritage as a unifying and stabilizing force for society. Attempts to modernize Latin America oscillated between liberal reforms and authoritarian repression throughout the tumultuous nineteenth century. There were frequent attempts to bring about reform of traditional structures, occasionally resulting in the violent overthrow of existing regimes and more often resulting in conservative reaction or military repression. ${ }^{14}$ Beginning as early as the eighteenth-century Bourbon Reforms and the

\footnotetext{
${ }^{12}$ Daniel H Levine, Religion and Politics in Latin America: The Catholic Church in Venezuela and Colombia (Princeton, NJ: Princeton UP, 1981), 3.

${ }^{13}$ David Martin, A General Theory of Secularization (New York: Harper \& Row, 1978), 5-6.

14 "Reform versus revolution" is a prominent theme in Latin America. See Marshall C. Eakin, The History Of Latin America: Collision of Cultures (New York: Palgrave Macmillan Publishing Co., Inc., 2007), 149, 351-376. Eakin devotes several chapters to examples of political reform, and yet other chapters to pre- and post-1959 revolutions.
} 
early nineteenth-century wars of independence and continuing through the twentieth century and into the post-WWII period of the Cold War, attempts at political reform have been constant among Latin American republics, sometimes escalating into full-scale revolutions in the twentieth century. ${ }^{15}$ In nineteenth-century Latin America, conflicts between anti-clerical Liberals and pro-Catholic Conservatives were at the heart of churchstate conflicts over education, church property, legal exemptions and constitutional guarantees of freedom of worship, or, on the other hand, concordats between the state and the church. $^{16}$

In the twentieth century, religious and political conflicts, often resulting from attempts to bring about political reform, have been just as frequent and often just as violent as in the nineteenth century. From the Cristero revolt in Mexico (1927-29) through the Spanish civil war (1936-39), La Violencia in Colombia (1948-56), and the Nicaraguan Revolution (1979), the church has often been at the center of attempts to resist or promote reform or revolution. ${ }^{17}$ Even estimating conservatively, hundreds of thousands of people

\footnotetext{
${ }^{15}$ See Timothy Wickham-Crowley, Guerrillas and Revolution in Latin America; A Comparative Study of Insurgents and Regimes since 1956 (Princeton, New Jersey: Princeton University Press, 1992), 300 . Wickham-Crowley analyzes a number of attempted revolutions in the latter half of the twentieth century such as the Bolivian Revolution (1952), Guatemalan reforms (1953), the Cuban Revolution (1959), and the Nicaraguan Revolution (1979). Also see Hannah Arendt, On Revolution (New York,: Viking Press, 1965).

${ }^{16}$ Eakin, Collision: 204-5.

${ }^{17}$ Matthew Butler, Popular Piety and Political Identity in Mexico's Cristero Rebellion : Michoacán, 1927-29 (Oxford: Oxford University Press, 2004). For an extreme case of Catholic involvement in Conservative politics, see Safford: Frank Safford and Marco Palacios, Colombia: Fragmented Land, Divided Society (Oxford, UK: Oxford UP, 2002), 164-8, and 188. For a discussion of the Catholic Church and the Spanish Civil War see Stanley G. Payne, Spanish Catholicism: An Historical Overview (Madison, Wisconsin: University of Wisconsin Press, 1984), 157-170. For information on religious factors in La Violencia in Colombia in 1948, see Safford, Colombia: 321, and Alexander Wilde, Conversaciones de Caballeros : La Quiebra de la Democracia en Colombia (Bogotá, Colombia: Ediciones Tercer Mundo, 1982).
} 
have died in bloody conflicts that had some element of religious conflict. In many cases, religion played a legitimizing role as an ally of political elites; in others, religion provided an ethical justification and moral inspiration for reformers or revolutionaries attempting to bring about social and political change. In Cuba from 1953 to 1961, the church vacillated and failed to take a clear position on the current political and social issues and eventually was marginalized in the Cuban Revolution (1959). In Brazil, after the military crushed attempts at political reform and imposed repressive measures on Brazilian society (1964), the Catholic Church moved into a stance of critical opposition to the military regime and became the primary defender of human rights while providing social space for resistance and eventual political reforms.

Youth and students have often been central to these reformist and revolutionary conflicts. Student movements in Latin America have a long tradition of involvement in national politics.Youth movements of various kinds began to appear in the nineteenth century. The World Student Christian Federation (WSCF) and the international Young Men's Christian Association (YMCA) organization had their origins in the midnineteenth century. Christian student movements held international conferences that brought together students both from advanced and developing nations and this interaction stimulated early student nationalism. Specifically political youth organizations followed in the twentieth century. The Socialist Youth International began in 1907 and claimed several thousand members, primarily from the German-speaking countries. Students actively opposed the growing militarism before the First World War. Most of the early in- 
ternational student activity ended with the war and only began again after $1918 .{ }^{18}$ Student movements in Spanish America rose to prominence with the university reform movement that dates its origins to the early twentieth century in the Southern Cone of South America. ${ }^{19}$ The Latin American university reform movement has been traditionally traced to the University of Córdoba in 1918. Nevertheless, Mark van Akin traces university reform to international university congresses that were held in Peru and Uruguay in 1908 and 1912 as the true origins of the movement. Despite the impression given in the historical literature regarding the beginnings of university reform, sentiments for university reform were percolating in various parts of Latin America at the turn of the century.

Since the growth and expansion of the university reform movement from Argentina to numerous other countries in South America and the Caribbean, Latin American university student movements have had a larger political significance in their respective countries compared with similar movements in North America. This was in part because of their frequent opposition to national governments and even occasional participation in the overthrow of governments. ${ }^{20}$

Why have Latin American students appeared to be more politically active and socially influential than their North American counter-parts, at least until the 1960s? Some possible factors include the lack of a full-time faculty and the presence of student participation in university government in most Latin American universities. Beginning in

\footnotetext{
${ }^{18}$ Philip G. Altbach, “The International Student Movement," Journal of Contemporary History 5.1, Generations in Conflict (1970): 159.

${ }^{19}$ Mark J. van Akin, "University Reform Before Cordóba," The Hispanic American Historical Review 51.3 (Aug 1971), 448.

${ }^{20}$ Kenneth N. Walker, “A Comparison of University Reform Movements in Argentina and Colombia," Comparative Education Review 10.2, Special Issue on Student Politics (June 1966): 256.
} 
1919 and continuing into the twenties, the reform movement spread to other Latin American countries, with varying success in the institution of reforms. ${ }^{21}$ It spread to Colombia in the early 1920s and Cuba in $1930 .^{22}$

The interwar years of the twenties and thirties were a period of ideological radicalization of students and youth. Nazi, Fascist, Communist, Socialist and Anarchist parties were intensively recruiting student participation in their various ideologies. The Catholic Church also entered wholeheartedly into the ideological competition with various youth organizations under the general umbrella of Catholic Action. Each of these competing ideologies, including conservative 'ultramontanist' Catholicism, had within them diverse and competing groups. ${ }^{23}$

The bitter experience of the Spanish Civil War and World War II facilitated diverging ideological orientations within Catholic student movements. The largely conservative Spanish and Italian Catholic youth organizations were influenced by their need to survive under the Falangist and Fascist regimes. Catholic students in France, Belgium, Canada and the United States identified with the allied western democracies and the fight against fascism and were influenced by democratic pluralism. ${ }^{24}$

\footnotetext{
${ }^{21}$ Walker, University Reform: 256, 263.

${ }^{22}$ Jaime Suchlicki, University Students and Revolution in Cuba, 1920-1968 (Coral Gables, FL.: U of Miami P, 1969) .

${ }^{23}$ Ultramontane means "over the mountain" and is used to describe the tendency toward a heavy focus on obedience to the Pope rather than church councils or a national church.

${ }^{24}$ Ana Maria Bidegain, personal conversation (Department of Religion, Florida International University, January 27, 2009).
} 
Students are often idealistic, tending to hold to a purist and Weberian "ethic of conviction" that bars political compromise and that leads student movements to confront national political institutions for their moral inconsistencies. ${ }^{25}$ The need of a younger generation to establish its independence from the preceding generation may often correspond to the dynamics of revolutionary political groups. ${ }^{26}$ Timothy Wickham-Crowley documented the average ages of revolutionary guerilla leaders in Latin America to be from the late twenties (Guatemala, Cuba) to the early thirties (Venezuela, Peru and Bolivia) ${ }^{27}$ It seems that at least one significant factor in reform and revolutionary movements is generational tension.

Although there are a number of other valuable studies on the political and religious roles of Catholic Action in other countries of Latin America, relatively less has been written on the political role of the Church in Cuba. ${ }^{28}$ Louis Perez, Jr.'s On Becoming Cuban contains a section specifically dealing with Catholic Action) as well as the North American connection to the Protestant Missions in $\mathrm{Cuba}^{29}{ }^{2}$ For background reading on

${ }^{25}$ Max Weber, "Politics as a Vocation," in The Vocation Lectures, ed. David Owen and Tracy B. Strong, trans. Rodney Livingston (Indianapolis, Ind.: Hackett Publishing Co., 2004), 83.

${ }^{26}$ Seymour Martin Lipset, "University Students and Politics in Underdeveloped Countries," in Students and Politics, ed. Seymour Martin Lipset (New York: Basic Books, 1967), 17-18; Philip G. Altbach, "Student Politics in the Third World," Higher Education 13, no. 6 (December 1984): 649.

${ }^{27}$ Wickham-Crowley, Guerrillas, 20.

${ }^{28}$ Luiz Alberto Gómez de Souza, A JUC: Os Estudantes Católicos e a Política (Petrópolis: Vozes, 1984); Ana María Bidegain, "La Organización de Movimientos de Juventud de Acción Católica en América Latina: Los Casos de los Obreros y Universitarios en Brasil y en Colombia Entre 1930 y 1956 " (Ph.D. diss., Brussels, Belgium: Universite Catholique de Louvain, 1979); Ana Maria Bidegain, "From Catholic Action to Liberation Theology: The Historical Process of Laity in Latin America in the Twentieth Century" (Working paper, Notre Dame, IN: Kellogg Institute for International Studies, 1985).

${ }^{29}$ Fernando Ortiz, Cuban Counterpoint: Tobacco and Sugar (London: Duke University Press, 1995); Louis A. Pérez, Jr., On Becoming Cuban: Identity, Nationality, \& Culture (New York: Ecco Press, 
the revolution, The Cuban Insurrection by Ramon Bonachea and Marta San Martin is helpful, giving specific information about Frank País, a Baptist pastor's son and leader of the July 26th Movement and Catholic student leader José Antonio Echeverría of the Directorio Revolucionario (Revolucionary Directory). A similar but more concise work is provided by Gladys Marcel García-Pérez, a Cuban historian. Although she avoids direct criticism of Fidel Castro's role in the revolution, García-Pérez's book provides a valuable overview of the development of the Cuban insurrection against Batista with a primary focus on Matanzas. ${ }^{30}$

In some respects, more has been written (at least in English) from a scholarly perspective on Protestantism in Cuba than Catholicism. A comprehensive study was carried out by Marcos Antonio Ramos. Rafael Cepeda edited a report on an ecumenical Protestant gathering in Matanzas in 1984 with interesting material on Protestantism and social concerns. Samuel Guy Inman documented a similar gathering in Havana in 1929. Luis Martínez-Fernández studied the early beginnings of Protestantism in Cuba and Puerto Rico in the nineteenth century. Jason Yaremko carries forward historical study of the growth of Protestantism after Cuban independence and convincingly demonstrates the strong connection between Protestantism and North American imperialism and docu-

1999), 230-242, 478, 487; Louis A. Pérez, Jr., Cuba: Between Reform \& Revolution (Oxford: Oxford University Press, 1995), 230-331.

${ }^{30}$ Although Bonachea and San Martin provide a good account of the Cuban insurrection, they demonstrate a notable disinterest in the political role of the Church and in particular the Catholic student lay organizations. Ramón L. Bonachea and Marta San Martín, The Cuban Insurrection 1952-1959 (New Brunswick, NJ: Transactions Books, 1995), 39, 44; Gladys Marel García-Pérez, Insurrection and Revolution: Armed Struggle in Cuba, 1952-1959, trans. Juan Ortega (Boulder, CO: Lynne Rienner Publishers, 1998). 
ments the eventual rupture between Cuban Protestants and U.S. missionary overseers. ${ }^{31}$

Studies of progressive Catholicism and Catholic Action youth movements in Cuba in the 1950s are even scarcer. Manuel Fernández Santalices was the former editor of Juventud, the official magazine of Catholic Action and was the co-founder of the progressive Franciscan journal La Quincena. Fernández has written several books on the role of the Church in pre-Revolutionary Cuba. ${ }^{32}$ Another helpful resource is La Voz de La Iglesia. This book consists of one hundred pastoral letters written by the Cuban bishops written from the mid-1950s through the 1980 s. $^{33}$

The only book that specifically focuses on Catholic Action in Cuba is Con la Estrella y la Cruz by Teresa Fernández Soneira, ${ }^{34}$ who provides a history of Catholic Action drawn primarily from personal interviews, magazines (Bohemia), newspapers (Diario de la Marina) and from the archives of the magazine, Juventud Católica Cubana, in Havana. The book quotes at length from abundant primary text material in a series of stories with

\footnotetext{
${ }^{31}$ Marcos Antonio Ramos, Panorama del Protestantismo en Cuba (San Jose, Costa Rica: Editorial Caribe, 1986); Rafael Cepeda, ed., La Herencia Misionera en Cuba (San José, Costa Rica: Editorial DEI, 1986); Samuel Guy Inman, Evangelicals at Havana: Being an Account of the Hispanic American Evangelical Congress, at Havana, Cuba, June 20-30, 1929 (New York: Committee on Cooperation in Latin America, n.d.); Luis Martínez-Fernández, Protestantism and Political Conflict in the NineteenthCentury Hispanic Caribbean (New Brunswick, NJ: Rutgers University Press, 2002); Jason Yaremko, U.S. Protestant Missions in Cuba From Independence to Castro (Gainesville, FL: University Press of Florida, 2000).

${ }^{32}$ La Quincena (Havana), 1956-1961, Special Collections, Florida International University; Manuel Fernández Santalices, Cuba: Catolicismo y Sociedad en un Siglo de Independencia (Caracas: Honrad Adenauer Stiftung, 1996); Manuel Fernández Santalices, Religión y Revolución en Cuba: Veinticinco Años de Lucha Ateista (Miami, FL: Saeta Ediciones, 1984).

${ }^{33}$ Joaquín Estrada Montalbán, comp. and ed., Iglesia Católica y Nacionalidad Cubana: Encuentros Nacionales de Historia (Miami, FL: Ediciones Universal, 2005); "Secretariado General Conferencia de Obispos Católicos de Cuba," La Voz de la Iglesia en Cuba, 100 Documentos Episcopales (México, D.F.: Conferencia de Obispos Católicos de Cuba, 1995).

${ }^{34}$ Teresa Fernández Soneira, Con la Estrella y la Cruz: Historia de la Federación de la Juventudes de Acción Católica Cubana (Miami, FL: Ediciones Universal, 2002).
} 
minimal editorial comment. The book provides footnotes but no bibliography. There is a need for a comprehensive historical work on the history of the Catholic Church in twentieth-century Cuba that considers its complex relationship with the Cuban state, the growing Protestant presence, and its contribution and failures in the period leading up to the Cuban Revolution.

There is an abundant literature on religion and politics in Brazil. One of the earlist studies was carried out by Ivan Vallier who did a comparative study of Catholicism in several Latin American countries including Brazil, Colombia and Chile using a Weberian theoretical framework. ${ }^{35} \mathrm{~A}$ more comprehensive and ground-breaking works was carried out in the early 1970s by Thomas Bruneau on the political role of the Catholic Church in Brazil. ${ }^{36}$ Even more helpful to my dissertation were the works of Scott Mainwaring detailing the historical background to the Brazilian young Catholic workers movement which overlaps with this dissertations focus on the Catholic university movement which drew its inspiration from the workers movement. Mainwaring is one of the foremost experts on the political role of the Brazilian Catholic Church in the 1960s. His study covered the origins of the Brazilian branch of the JOC, Juventude Obrera Católica, in the 1950s and early 60s leading up to and influencing the development of liberation theolo-

\footnotetext{
${ }^{35}$ Ivan Vallier, Catholicism, Social Control, and Modernization in Latin America (Englewood Cliffs, NJ: Prentice, 1970), 131.

${ }^{36}$ Thomas Bruneau, The Political Transformation of the Brazilian Catholic Church (Cambridge, UK: Cambridge University Press, 1972) and The Church in Brazil: The Politics of Religion (Austin, TX: The University of Texas Press, 1982).
} 
gy. ${ }^{37}$ There are several studies that focus specifically on the Brazilian university and student movrments including Leonard D. Therry who focused on the precise period leading up to the military coup that dispensed with the democratic process and a dissertation by Laura Da Veiga that gave more historical background to the process of reform of the Brazilian University. ${ }^{38}$

Andrew Chesnut has carried out several studies of evangelical Pentecostalism in Brazil using microeconomic theory. ${ }^{39}$ Other studies of religion and politics in Brazil include John Burdick's comparative study of progressive (liberationist) Catholicism with Pentecostalism and Afro-Brazilian spiritism. ${ }^{40}$ José Casanova, in his Public Religions in the Modern World, studied what he described as the twentieth-century Catholic Reformation in five predominantly Catholic countries including Brazil. He examed the role of separation of church and state, religious pluralism and secularization and found that those countries that have become overwhelmingly secular are most often countries where the church had a state sanctioned monopoly. Countries where there was separation of church and state, religious pluralism, or where the Catholicism was an oppressed majority, have

${ }^{37}$ Scott Mainwaring, The Catholic Church and Politics in Brazil, 1916-1985 (Stanford, CA: Stanford University Press, 1986), 118; Mainwaring, Scott. "A JOC e o Surgimento Da Igreja Na Base (1958-1970).” Revista Eclesiástica Brasileira 43, no. 169 (March 1983): 29-92.

38 Leonard D. Therry, "Dominant Power Components in the Brazilian University Student Movement Prior to April, 1964," Journal of Inter-American Studies, Vol. 7, No. 1 (Jan 1965); Laura Da Veiga, "Reform Of The Brazilian University: The University And The Question Of Hegemony (19541968)," diss. (Palo Alto, California: Stanford University, 1981).

${ }^{39}$ R. Andrew Chesnut, Born Again in Brazil: The Pentecostal Boom and the Pathogens of Poverty (New Brunswick, NJ: Rutgers University Press, 1997) and Chesnut, Competitive Spirits: Latin America's New Religious Economy (Oxford, UK: Oxford University Press, 2003).

40 John Burdick, Looking for God in Brazil: The Progressive Catholic Church in Urban Brazil's Religious Arena (Berkeley, CA: U of California P, 1993). 
continued to be highly religious even with the advent of modernism. Casanova included Brazil in the latter category because of its religious pluralism. He noted that Catholic Action and Christian Democracy began as part of a voluntary Catholic disestablishment and as part of a Catholic response to secularist, laicist and mass parties at the turn of the century. $^{41}$

Other works that deal specifically with the various branches of Catholic Action in Brazil have been written by Ana Maria Bidegain, José Oscar Beozzo and Luís Alberto Gómez de Sousa. ${ }^{42}$ The historical narratives and time lines established in the works by Beozzo and Souza were particularly helpful in interpretation of primary source material for the Catholic university movement in Brazil. Since the mid-1980s, few studies have been conducted on the postwar Catholic university movements; more recent works such as that by Kenneth Serbin have concentrated on other aspects of the priesthood or the relationship with of the hierarchy with the state security apparatus during the military regime. $^{43}$

Two books have a direct bearing on the theme of revolution and repression. Carlos Alberto Libanio Christo, better known as "Frei Betto" was a Catholic student leader in Rio de Janeiro during the military takeover in Brazil of April 1964, and was later im-

\footnotetext{
${ }^{41}$ José Casanova, Public Religions in the Modern World (Chicago, IL: The University of Chicago Press, 1994), 62.

${ }^{42}$ Bidegain, "La Organización"; Bidegain, "From Catholic Action"; Luiz Alberto Gómez de Souza, A JUC: Os Estudantes Católicos e a Política (Petrópolis: Vozes, 1984); Souza, A JUC; José Oscar Beozzo, Cristãos Na Universidade e Na Política (Petrópolis: Editora Vozes, 1984).

${ }^{43}$ Kenneth P. Serbin, "Church-State Reciprocity in Contemporary Brazil: The Convening of the International Eucharistic Congress of 1955 in Rio de Janeiro," The Hispanic American Historical Review 76.4 (Nov 1996); Secret Dialogues: 2000; Needs of the Heart: A Social and Cultural History of Brazil's Clergy and Seminaries (Notre Dame: U of Notre Dame P, 2006).
} 
prisoned and tortured. His best known book consists of a series of interviews with Fidel Castro on the subject of religion. ${ }^{44} \mathrm{He}$ also wrote his memoir of the period of clandestine resistance to the military and his eventual capture and imprisonment. ${ }^{45} \mathrm{~A}$ similar book, written by a former Marxist converted to Catholicism through the witness of Catholic university students was written by Marcio Moreira Avles, a liberal journalist from Rio. Alves analyzes the military regime in great detail, arguing that the so-called "economic miracle" has benefited North American capitalists more than the Brazilian people. He gave evidence that the torture of prisoners continued in spite of international protest. ${ }^{46}$

The primary focus in this dissertation involves the relationship among Catholic university movements, the Catholic clerical hierarchies and the interplay of national politics and transnational ideological and geo-political influences. A secondary emphasis focuses on the influence of the Catholic university student movements on changes within Catholicism prior to the Second Vatican Council (1962-1965) and the subsequent rise of liberation theology in Latin America. ${ }^{47} \mathrm{~A}$ third emphasis is the significant social role of university students in the rapidly modernizing Latin American societies in the 1950s. Therefore, it is important to explore the contribution of Catholic university student

\footnotetext{
${ }^{44}$ Frei Betto, Fidel Y La Religion: Conversaciones Con Frei Betto Sobre El Marxismo Y La Teologia De La Liberacion (Bogotá, Colombia:: Editorial La Oveja Negra, 1986).

${ }^{45}$ Frie Betto, Batismo de Sangue a Luta Clandestina Contra a Ditadura Militar, Dossies Carlos Marighella e Frei Tito (Rio de Janeiro, RJ: Civilização Brasileira, 1982, 1982).

${ }^{46}$ Marcio Moreora Alves, A Grain of Mustard Seed: The Awakening of the Brazilian Revolution (New York City: Anchor Books., 1973).

${ }^{47}$ Bidegain, "Catholic Action to Liberation Theology," 18.
} 
movements to the subsequent development of trends within Catholicism in Latin America. In many countries the difficulties of the nation-building process have led to a formulation of a high prestige and elite student status that is seen as socially and politically central to the national project. Consequently, in many developing countries students are among the most politically active social groups and bear a relatively high degree of social influence within their societies. ${ }^{48}$

Theories of Religion and Social Change

The present study analyzes the expansion and political influence of the Catholic student movements in Cuba and Brazil from 1946 to the mid-1960s through textual analysis of the changing religious and social discourse. The study will utilize concepts from the work of Max Weber, Antonio Gramsci, José Ortega y Gasset and Karl Mannheim on generational change and ideology and more recent work by Daniel Levine on religion and politics, as well as works on Catholic Action by Ana Maria Bidegain, José Oscar Beozzo and Luís Alberto Gómez de Sousa. Aurora G. Morcillo’s study of Catholicism under Franco in Spain adds depth to the analysis with regard to the role of gender ideology among Catholic students. In regard to student activism, K. H. Silvert, Seymour Martin Lipset, E. Wight Bakke, John W. Myer and Richard Rubinson, Philip G. Altbach and Louise Bienvenue provide valuable theoretical approaches to the political activism of university students. $^{49}$

\footnotetext{
${ }^{48}$ John W. Meyer and Richard Rubinson, "Structural Determinants of Student Political Activity: A Comparative Interpretation,” Sociology of Education 45.1 (Winter 1972): 25.

${ }^{49}$ Lipset, Students and Politics. 1967; Philip G. Altbach, Student Political Activism: An International Reference Handbook (New York: Greenwood Press, 1989) and Student Politics in America:
} 
Luis Alberto Gomez de Souza, citing the Italian Marxist theorist, Antonio Gramsci, has pointed out that the church is an organized expression of religious activity inserted into society, and the church members necessarily belong to a structure of social classes within the society. These church members, therefore, carry the conflicts and class alliances of the surrounding society into the interior of the church. The dominant religious expression in society is likely to be an expression of the ideology of the dominant social class. Religion is present in all sectors and social dimensions including ideological and class conflict and these social conflicts will also affect the church. ${ }^{50}$

German historical sociologist Max Weber (1864-1920) pioneered the study of the influence of religion and religious beliefs in the public and economic spheres through his analysis of institutions, leadership dynamics and the sociology of religions. He attempted to demonstrate how certain pervasive religious beliefs might encourage the development of dominant social values with an 'elective affinity' to certain economic developments thus influencing the gradual transformation of social and economic structures. Weber made this argument in the Protestant Work Ethic and the Spirit of Capitalism" written in $1905 .{ }^{51}$ Weber's conclusions have been contested and attempts to utilize Weberian analysis in developing regions such as Latin America have been criticized for over-

\footnotetext{
A Historical Analysis; Philip G. Altbach, Student Politics in America: A Historical Analysis (New York: McGraw-Hill, 1989). See also K. H. Silvert, "The University Student." Continuity and Change in Latin America, ed. John J. Johnson (Stanford, Calif.: Stand; Stanford University Press, 1964), 206-27; Louise Bienvenue, Quand la Jeunesse Entre en Scene: L'Action Catholique Avant la Revolution Tranquille (Montreal: Les Editions du Boreal, 2003).

${ }^{50}$ Souza, $A J U C, 25$.

${ }^{51}$ Max Weber, The Protestant Ethic and the Spirit of Capitalism, trans. Talcott Parsons (New York: Charles Scribner's Sons, 1958), 80, 153.
} 
simplification and for overlooking important geo-political and path-dependent historical factors that were necessary for the rise of international capitalism and the Industrial Revolution in Western Europe and the Atlantic periphery. ${ }^{52}$

Weber does not accord to religion a unilinear causal influence on economics but he does provide a framework which allows for consideration of the intervening influence of such 'superstructural' variables. ${ }^{53}$ Weber distinguishes between two different types of religion that serve distinct social functions according to social class. In Weber's view, religious demands tend to organize themselves around two kinds of social class situations: those who are socially dominant and those who are subordinate. The existence of distinct social classes may result in two kinds of religious orientation: religions of salvation and religions of adaptation to the world. The elite and governing classes tend to adhere to religion as adaptation to the world and tend to use it in order to legitimate the established order. Religions of salvation tend to incorporate the idea of compensation to the lower classes for their suffering during their lives. ${ }^{54}$ According to Brazilian political scientist, Gomez de Souza, the second kind of religious signification, the religion of salvation, is more favorable to social revolution. ${ }^{55}$

${ }^{52}$ Brian H. Smith, Religious Politics in Latin America, Pentecostal vs. Catholic (Notre Dame, IN: University of Notre Dame Press, 1998), 31.

${ }^{53}$ Marx considered social reality to be divided between the economic base and the resulting cultural and social super-structure. Material and economic factors belong to the base. Cultural factors such as religion, beliefs, and values are relegated to the superstructure; See Robert C. Tucker, The Marx-Engles Reader (New York: W. W. Norton \& Company, 1978), 149-150.

${ }^{54}$ Max Weber, The Sociology of Religion (Boston: Beacon Press, 4th ed. 1991), 89, 97.

${ }^{55}$ Souza, A JUC, 21-22. 
The underdeveloped nations of Latin America, including Brazil and Cuba, have a century's long tradition of hegemonic Catholicism. Catholicism has not been homogenous, however. An elite Catholicism, oriented around the dominant classes, provided a form of social legitimation for the established order. Traditional elite Catholicism would conform to Weber's type of religion as an adaptation. In addition, a type of popular Catholicism, conforming to Weber's salvation model, brought comfort and meaning to the poor and suffering classes of Brazil, particularly in the rural areas. Occasionally in Brazil there have been millenarian movements that have instigated social upheaval and rebellion against the established order. Some of these types of Catholicism, along with various kinds of Pentecostalism and Afro-Spiritist religions are also classified as religions of salvation.

Antonio Gramsci has had a significant influence on theorists of religion and politics in Latin America. Although Gramsci was a Marxist and an admirer of Lenin, he was also familiar with Weber's work. He was critical of the "mechanical determinism" among pre-World War I Marxists who, in Gramsci's view, were passively waiting for the correct economic conditions to bring about a social revolution. ${ }^{56}$ Gramsci became one of the founders and leaders of the Italian Communist Party, which eventually led to his arrest and imprisonment under Mussolini. His most significant writings were written in prison in the 1930s and published in the 1950s as the Prison Notebooks. ${ }^{57}$

\footnotetext{
${ }^{56}$ Roger Simon, Gramsci’s Political Thought, An Introduction (London: Lawrence \& Wishart, 1982), 14.

${ }^{57}$ Antonio Gramsci, Selections from the Prison Notebooks (New York: International Publishers, 1971), 331-332.
} 
Gramsci was fascinated by the intellectual and normative influence that Italian Catholicism exercised over the popular and peasant classes. He carefully studied the role and function of Italian Catholic Action to better understand the Catholic success in the formation of hegemonic religious values in Italian society. Gramsci's theoretical views included an extensive discussion about the relationship between religion and ideology. Gramsci sought to understand how the Italian workers and peasants might effectively be mobilized to act on behalf of a social revolution that would take control of the state and change economic structures in order to benefit all of society and not just the capitalist class. Gramsci was, thus, one of the first thinkers to investigate popular social movements and has provided the theoretical and conceptual foundation for much of the contemporary literature on social movements. ${ }^{58}$ In particular, Gramsci analyzed sodalities,${ }^{59}$ within the Catholic Church such as the Jesuits, Franciscans and Catholic Action ${ }^{60}$ and their role in developing and to main-

${ }^{58}$ Gramsci, Prison Notebooks, 337.

59 "Sodality" is a church structure expressed in specialized, task-oriented form as opposed to the Christian church in its local, diocesan form. Sometimes the word confraternity is also used interchangeably. Sodalities often are highly mobile, and may have a quasi-military structure. Among Protestants, sodalities are expressed through mission organizations, societies, and specialized ministries.

${ }^{60}$ The term, "Catholic Action" (Italian: Azione Cattolica) was applied loosely to the whole range of lay initiatives within Catholicism. The roots of Catholic Action can be traced to a network of layoriented, self-help institutions, centered on the parishes, and organized by the Opera dei Congressi (founded in 1874). Pope Pius X dissolved Opera dei Congressi in 1904. Pope Pius XI issued new statutes for Catholic Action in 1923. He intended to use Catholic Action as a mass-mobilizing force rivaling the Fascist movement and attempting to mobilize Italian society under Catholic influence. Italian Catholic Action was divided into four lay associations: men, male youth (including university students), women, and young women. This was known as the "Roman" or "generalized" model of Catholic Action and remained in force until 1946. Pius XI eventually became known as the "Pope of Catholic Action." Pius XI defined Catholic Action as the "participation of the laity in the apostolate of the hierarchy," which implied that it could not be a political party or labor union. The lay participants were to prepare for the "conquest" or reChristianization of society. See Paul Misner, "Catholic Labor and Catholic Action: The Italian Context of Quadragesimo Anno," The Catholic Historical Review 90, no. 4 (October 2004): 13-18. 
taining a religious and ethical worldview among the Italian masses. Rather than dismis any constructive role for religion as Marx appeared to do, Gramsci looked for lessons that could be drawn from the practical functioning of Catholicism, both as an elite hierarchy as well as a form of popular religious belief among common people. ${ }^{61}$

Gramsci was pessimistic about the prospects for a violent overthrow of the ruling order. Classic Marxist-Leninism presupposed the existence of a vanguard party mobilizing and leading workers and peasants in order to seize the monopoly on the legitimate use of force of the state and to impose new economic structures upon society. Gramsci called this type of revolution, the "war of maneuver," which, in his view, did not have a high probability for success in the context of Italian fascism. He proposed an alternative "war of position" which required a gradual process of education of the popular masses in order to inculcate a revolutionary consciousness into them, thus enabling them to develop a type of counter-hegemony. ${ }^{62}$ According to Gramsci, the ideological war of position must first be won in the minds of the people before the war of maneuver could lead to a 'cathartic' situation (revolution) in which genuine socialism could be installed through the state. $^{63}$

${ }^{61}$ Gramsci, Prison Notebooks, 338.

${ }^{62}$ Hegemony is "the political, economic, ideological or cultural power exerted by a dominant group over other groups, regardless of the consent of the latter." Gramsci developed the concept of cultural hegemony and showed how a social class exerts cultural "leadership" or dominance of other classes in maintaining the socio-political status quo. Cultural hegemony identifies and explains domination and the maintenance of the status quo and persuades the subordinated social classes to accept and adopt the rulingclass values. "Counter-hegemony" was the process of challenging and changing the hegemony through education and the raising of consciousness. See Gramsci, Prison Notebooks: 12-13, 182.

${ }^{63}$ Gramsci, Prison Notebooks: 88, 120, 229, 366-7. 
Gramsci's concept of the "war of position" bears a resemblance to the concept of revision of life, or the development of a critical consciousness used by the Catholic student movements. The Catholic student movements focused on a type of character formation among new students in order to form a critical awareness in the student. In Brazil, Gramsci's idea of conscientização was very similar to other initiatives such as the mass literacy movement sponsored in partnership by the Brazilian government and the Catholic Church and supported by heavy participation of Catholic students. Nevertheless, despite the attempt by Catholic activists in Brazil to work for reforms through a gradual educational process, there existed an increasingly chaotic social fervor along with growing political instability. Eventually, Brazilian elites in conjunction with military leaders brought about a general repression against the reformist elements among students and Catholics. In Cuba, a "cathartic" situation also existed but it existed under a corrupt government and a demoralized military, and the result was a dramatic and popular social revolution.

In order to win the war of position, in Gramsci's view, it was necessary to understand the "common sense" of the people and to help them to learn to think critically and to develop "good sense" or a coherent philosophy that was in their own class interest. ${ }^{64}$ The process of developing a counter-hegemonic worldview among the masses required the recognition and encouragement of "organic intellectuals" who arise from the popular classes, but who learn to think critically, coherently and who stay vitally linked to their

\footnotetext{
${ }^{64}$ Gramsci, Prison Notebooks: 419; Simon, Gramsci: 65. Gramsci uses "common sense" in a pejorative way, as sense that is the uncritical conception of the world of the popular classes which is fragmentary, incoherent and inconsequential.
} 
ordinary class background. Gramsci drew numerous parallels between the work of the organic intellectuals and the Catholic clergy and religious orders. In Gramscian theory, as more and more organic intellectuals were developed, and as they, in turn, helped their fellows develop their uncritical common sense philosophy into a good-sense ideology, the counter-hegemonic war of position gradually advances in the realm of the cultural superstructure ${ }^{65}$ Gramsci's concept of ideological hegemony has been criticized by others such as James Scott on the basis of his empirical ethnographic studies poor workers in Malaysia. ${ }^{66}$ Scott found that the poor were very aware of their real interests. His research revealed that the poor found ingenious ways to utilize prevailing ideologies as strategies of resistance similar to the "moral economy" of eighteenth-century English peasants. ${ }^{67}$

It might be asserted that the Catholic student movement focused on producing "organic intellectuals" out of the student population who were focused on the needs of the underprivileged classes in Brazil and who could articulate their needs with critical consciousness and modern social science tools. Left-leaning Catholic students reformulated religious vocabulary with biblical references to develop a language of reform that Catholic peasants and workers could easily understand. The Catholic discourse of reform provided an ideological bridge for these same peasants and workers from traditional Catholicism (religion of adaptation) to progressive liberationist (religion of salvation). The

${ }^{65}$ Gramsci, Prison Notebooks: 14-16; 330-331.

${ }^{66}$ James C. Scott, Weapons of the Weak: Everyday Forms of Peasant Resistance (New Haven and London: Yale University Press, 1987), 286.

${ }^{67}$ Scott, Weapons of the Weak, 307, 311, 336; E. P. Thompson. "The Moral Economy of the English Crowd in the Eighteenth Century." Past and Present, 50 (February 1971): 136. 
common people in Latin America would not have been comfortable with secular revolutionary ideas drawn from Marx without a public discourse that included Catholic concepts of social justice and liberation and the apparent endorsement of the social teachings of the Popes.

The main difference between religion and ideology, in the context of the present study, is the orientation of ideology toward public policy and the political community. In Gramsci's and Scott's studies, both were dealing with communities that espoused universalistic religions offering a comprehensive worldview that included ethical and normative rules for the politics and economics. In Gramsci's context, it was Italian Roman Catholicism which not only shaped the worldview of the vast majority of Italians, but also laid claim to universally applicable moral authority with implications for public policy through its social teachings and through Catholic political parties. In Scott's study, Islam fulfilled a similar role with peasants. Thus, ideology is comingled with religion in both Gramsci and Scott's work. ${ }^{68}$

Ideology provides people with rules of practical conduct and moral behavior, and is equivalent to "a religion understood in the secular sense of a unity of faith between a

${ }^{68}$ Both Gramsci and Scott gave substantial attention to the role of religion and ideology in their writings. In fact, one might make the argument that religious beliefs and ideology are nearly interchangeable in their studies. Although there are a myriad of definitions for religion and ideology it might be helpful to establish a destinction. In Fabio Petito and Pavlos Hatzopoulous, Religion in International Relations: The Return from Exile (New York: Palgrave MacMillan, 2003), 93, Vendulka Kubálková defines Religion as "a system of rules and related practices which act to explain the meaning of existence, including identity, ideas about self, and one's position in the world, thus motivating and guiding the behavior of those who accept the validity of these rules on faith and who internalize them fully." A definition of ideology offered by Michael Freeden shows how closely these two cultural elements are related: "A political ideology is a set of ideas, beliefs, opinions, and values that exhibit a recurring pattern, are held by significant groups, compete over providing and controlling plans for public policy, do so with the aim of justifying, contesting, or changing the social and political arrangements and processes of a political community." Michael Freeden. Ideology, A Very Short Introduction (Oxford: Oxford University Press, 2003), 32. 
conception of the world and a corresponding norm of conduct. ${ }^{.69}$ Gramsci was aware that a fundamental problem facing any worldview which has taken root in popular culture in the form of a religion or an ideology was how to preserve the ideological unity of the entire social bloc which that ideology serves to unify. ${ }^{70} \mathrm{He}$ understood that the strength of Catholicism was found in the clergy's careful attention to maintaining the doctrinal unity of the faithful. Gramsci saw religion as part of the common sense of the popular class and believed that critical awareness or 'good sense' philosophy superseded religion and common sense. $^{71}$

Because Gramsci had a less dismissive view of religion than Marx, it is no accident that many Latin American theologians found the Gramscian perspective useful for theoretical analysis. Gramsci's idea of developing the skills of critical thinking in the common person had striking parallels to some of the approaches to consciousness raising utilized in Catholic communities and the development of social awareness within the Catholic student movements.

University students play a particularly significant role in underdeveloped nations such as those of Latin America. In many Latin American nations, students, as members of the elite society, are expected to take a large share of responsibility for developing a vision for national identity. University students are generally idealistic and often play a prophetic or catalytic social role in confronting institutional incongruities between rhetoric and reality in the political, social and religious spheres.

\footnotetext{
${ }^{69}$ Simon, Gramsci: 59; Gramsci, Prison Notebooks: 326.

${ }^{70}$ Gramsci, Prison Notebooks: 328.
} 
The life of a university student, especially in Latin America, provides an interesting analogy to Scott's "hidden transcript" situation. ${ }^{72}$ University students occupy unique liminal space between youth and adulthood in which they are no longer under direct parental control, but neither have they begun to shoulder the adult responsibilities of marriage, parenthood and career. In Spanish-speaking countries of Latin America, there is also a long tradition of university autonomy which intensifies this relative period of academic freedom. Students often relocate from local and provincial locales (thus, reducing the influence of traditions) to an urban university community where they are encouraged to think critically and to question traditional sources of authority. ${ }^{73}$ In other words, students are encouraged to speak from their hidden transcripts with only minimal restraint from the hierarchies of power. Students become aware of the gap between rhetoric and performance of adult political and religious institutions and often adopt a radically critical stance built on a youthful idealism or in Weberian terms, an "ethic of conviction.",74

The transition between generational cohorts may be a key element in the process that moves advances social change. Karl Mannheim defined a chronological generation as a group of youths who rise to adulthood facing the same concrete historical problems; basically, a span of time lasting roughly twenty to thirty years. According to Mannheim,

\footnotetext{
${ }^{71}$ Ibid., 325-326.

${ }^{72}$ Scott uses the term "hidden transcript" to describe what people have to say about their social or political situation when they are safe from possible reprisals from dominant elites or those who have power over them. The hidden transcript is what people really think, when they are being honest. Scott, Weapons of the Weak: 287.

${ }^{73}$ Kurt H. Wolff, From Karl Mannheim, (New Brunwick, New Jersey: Transaction Publishers, 1993), 368 .

${ }^{74}$ Max Weber, "Politics as a Vocation." The Vocation Lectures, Ed. David Owen and Tracy B. Strong, trans. Rodney Livingston (Indianapolis, Ind.: Hackett Publishing Co., 2004), 80.
} 
friction and conflict between generations tend to intensify in periods of rapid social change. ${ }^{75}$ José Ortega y Gasset believed that generational change was the key mechanism in history for understanding the process of social change and believed that every generation was given a historical mission. ${ }^{76}$ Ortega had the insight to examine not only the generation as a free-standing social grouping, but emphasized the role of intergenerational conflict and transmission of values and worldview as an important factor in social dynamics. According to Ortega, at any one time the ruling social order or vigencia, included two adult generations struggling for dominance. One generation, from forty-five to sixty years of age, controls the dominant resources of society while the other generation, from thirty to forty-five years of age, is in the struggle of achievement and attempting to take social control. At the same time, the generation of rising young adults or youth, from roughly fifteen to thirty years of age, are in an impressionable stage of preparation for adult responsibilities and are observers to the struggle for dominance of the two elder generations.

In Ortega's theory, productive social change depends largely on the interplay between relationships between these two adult generations and the rising youth generation. If the dominant adult generation failed to prepare the younger generation, or if the younger generation failed to embrace its historical mission, the result may be social stag-

\footnotetext{
${ }^{75}$ Wolff, Mannheim, 377.

${ }^{76}$ Ortega Y Gasset, The Modern Theme (New York: Harper, 1961), 26.
} 
nation and failure, as Ortega believed was the case with his generation of Spaniards between the World Wars. ${ }^{77}$

Some generations felt a profound break with the past; these generations lived in eliminatory or polemical epochs; and such periods produced combat generations that attacked their predecessors and delineated themselves in terms of what they opposed. $\mathrm{Cu}$ mulative epochs were dominated by old men; eliminatory epochs were times of youth. The rhythm of elder-dominated periods followed by epochs of youth seemed to Ortega to be an obvious phenomenon. Ortega proposed the creation of a new scientific discipline of metahistory, which would have the same relationship to history as human physiology had to the medical clinic. One of the most important historical investigations, he suggested, would be to discover the rhythms of alternation between epochs of youth cohorts and generational change. Ortega also asserted that each generation had its vocation or its historical mission. $^{78}$

In Mannheim's conception, in order to belong to a generation, it was not enough enough to be of a certain age; one also had to have some "vital contact" with the other members of the same cohort. The space within which generations lived varied in size according historical events with the time period. Community of time and space and a shared sense of crisis were the primary attributes of a generation. Together they signified "the sharing of an essential destiny." ${ }^{79}$ Th essential destiny in turn, produced in generational

${ }^{77}$ In Ortega's view, Generation, was conceived as a "dynamic compromise between the individual and the mass, was the most important concept in history and the hinge upon which history executed its movements," Wolff, Mannheim, 139.

\footnotetext{
${ }^{78}$ Wolff, Mannheim, 140.

${ }^{79}$ Ibid., 152.
} 
coevals secondary characteristics that resulted in a unity of style of life. By the late 1950s, the leading edge of the postwar generation began to come of age during a time of accelerated social transition. ${ }^{80}$

Catholic student movements in Latin America had a hegemonic religion as their point of departure in the development of student ideologies. In both of the case studies examined in the dissertation, there was a national heritage of Luso-Iberian Catholicism stretching back to the pre-colonial (medieval) era. Catholicism in Latin America may have been monopolistic but it has never been monolithic. Latin American Catholicism has always been complex, varied and nuanced. ${ }^{81}$ Nevertheless, in the early twentieth century, Latin American Catholicism has often functioned as a religion of adaptation, providing governing elites with religious and ideological legitimation for their rule.

My dissertation argues that the Catholic university movements created the opportunity for students to critically re-examine elite Catholicism. These Catholic students questioned the traditional legitimating role of Catholicism and began to use the social teaching of the church in a gradual process of growing critical awareness regarding social inequities and economic dependency. Catholic students were encouraged by the episcopacy to engage their secular academic and scholarly environments as apostolic missionaries on behalf of the church. The transculturation process was dialectical and bilinear causing a gradual change in Catholic student ideology that moved inexorably from the elite

\footnotetext{
${ }^{80}$ Wolff, Mannheim, 378-9.

${ }^{81}$ Thomas C. Bruneau, The Church in Brazil: The Politics of Religion (Austin, TX: The University of Texas Press, 1982), 47.
} 
oriented "religion as adaptation" to revolutionary religion as "salvation". The Catholic student leaders became types of "organic" intellectuals (in the Gramscian sense), at least within their own middle-class student ranks and quickly gravitated from a reforming vision to a revolutionary consciousness. These students provided key leadership and support for the Cuban Revolution and attempted to bring about political reforms in Brazil under João Goulart.

Research Design

My study examines five primary variables: (1) institutional influence, (2) transnational ideological resources, (3) social inequity, (4) the geo-political context and (5) political ideology. The four independent variables are: Institutional influence which includes the formation of the Brazilian Bishops conference in 1952, the encouragement of the lay apostolate by Popes Pius XI, Pius XII and John XXIII, and the key role of clerical advisors and progressive priests such as Hermano Victorino and Ignacio Biaín in Cuba, and Frei Romeu Dale and Dom Cândido Padim in Brazil; Transnational ideological resources includes the influence of the methodology of the Young Catholic Workers and Specialized Catholic Action in Europe, ideological differences among competing international Catholic organizations, progressive philosophical and theological developments within French Catholicism; and the social teaching of the church combined with the growing popularity of dependency theory in Latin America. Social inequity includes the severe poverty and social inequalities in Brazil and Cuba, rapid urbanization, the growth of higher education associated with modernity, the emergence of new popular social classes and the appearance of the postwar youth culture. The geo-political variable includes the influence of post-colonial nationalism, the Cuban Revolution, the Cold War 
and chronic instability in both the Brazilian and Cuban states. The dependent variable is political ideology which became increasingly radicalized in Brazilian JUC from 1959 through its dissolution in 1966 and increasingly conservative among many Cuban Catholic students after the triumph of the Cuban Revolution.

Research was carried out using primary source materials such as personal letters, newsletters, organizational bulletins, official correspondence, newspaper articles, unpublished conference reports, doctrinal statements and papal encyclicals and recorded interviews. Ana Maria Bidegain's papers, housed in the religion department of Florida International University provided primary sources for a variety of organizations and nationalities. The Cuban Heritage Collection was an invaluable source of journals, such as the Franciscan La Quincena, newspapers such as the Diario de la Marina and rare biographies. The Latin American Collection at the Smather's library of the University of Florida in Gainesville houses an excellent collection of Brazilian newspapers on microfilm. Hundreds of primary documents including bulletins and letters were reviewed and analyzed at the library of the arcebispado (archbishop's library) in Havana, Cuba. Finally, forty recorded interviews with former student activists were available for analysis at the Center for Scientific Information and Documentation (CEDIC) at the Pontifical Catholic University in Sao Paulo, Brazil.

Chapter two gives the historical context of the development of Catholic Action and Catholic student movements in the interwar period of the 1920s and 1930s, along with a review of the literature on Catholic Action and student activism. During this period a divergence between two types of Catholic Action will examined: Italo-Hispanic general Catholic Action and Franco-Belgian specialized Catholic Action. 
Chapter three examines the reorganization and expansion of several Catholic student movements in the postwar period and the transnational ties formed between the coordinating centers in Paris and Switzerland with Catholic youth organizations that had already spread throughout much of what has been traditionally regarded as Atlantic civilization; North and South America, the Caribbean, West Africa and Europe. Then, the specific cases of Catholic university movements in Cuba (1953-1962) and Brazil (19561966) are examined in Chapters four and five, an eventful time period that encompasses the Cuban Revolution (1959), the Cuban missile crisis (1962), the Brazilian military coup (1964) and the Second Vatican Council in Rome (1962-1965). Chapter six analyzes the Brazilian and Cuban Catholic Student movements and their demise and will provide contrasts and comparisons in the context of the transnational factors. 



\section{CHAPTER II}

CATHOLIC ACTION: EUROPEAN ROOTS, 1922-1939

In the 1920s, two men took steps to revitalize Catholicism in Europe and succeeded in permanently influencing its direction, although in significantly diverging ways: Pope Pius XI (1857-1939), born to Italian peasants as Achille Ratti, and Joseph Cardijn (1882-1967), the humble son of Belgian working-class parents. Chapter two demonstrates that Ratti and Cardijn each exercised decisive but profoundly different influences in transnational Catholic lay movements that came to be known collectively as Catholic Action. Each man responded to a complex set of national, ideological, social and geopolitical challenges that required different solutions. By the same token, each one was passionately motivated by very different concerns. ${ }^{1}$

Ratti and Cardijn lived in almost the same time period in interwar Europe of the 1920s through the 1930s but in very different social contexts, and each faced different challenges. For Cardijn, the challenge was to recover the urban proletariat for the Catholic faith in urban areas of heavily industrialized Belgium. His primary competitor for their allegiance was socialism. ${ }^{2}$ For Achille Ratti, of peasant background, the challenge was to reestablish the institutional influence of the Catholic Church in Catholic Europe, especially in semi-industrialized and rural Italy. His primary competitor eventually became the

\footnotetext{
${ }^{1}$ Robin Anderson, Between Two Wars: The Story of Pope Pius XI (Achille Ratti, 1922-1939) (Chicago: Franciscan Herald Press, 1977), 38-44; Michael De La Bedoyere, The Cardijn Story (Milwaukee, Wisconsin: The Bruce Publishing Co., 1958), 26.

${ }^{2}$ Susan B. Whitney, Mobilizing Youth : Communists and Catholics in Interwar France (Durham: Duke UP, 2009), 81.
} 
Italian fascist party. ${ }^{3}$ Both men were heavily focused on reaching the youth of Europe, although in significantly different ways.

Ratti's tenure as the world leader of international Catholicism (1922-39) coincided with the rise of totalitarian ideologies on the left and the right and a major world depression. His primary concern was to protect the influence of the Catholic Church, particularly in Italy, and his favorite organization for Catholic lay people, Catholic Action. The 1920s and 1930s marked the rise of a generational consciousness of youth, and the partisans of authoritarian ideologies rushed to enlist the new generation of young workers, students, peasants, young men and women to their cause. ${ }^{4}$ Pius XI made every possible effort to ensure that the Catholic Church would have the competitive edge in the moral contest with Liberalism, Marxism, and Fascism for the allegiance of the young. In the crusade to rechristianize Europe, the Catholic Action youth and the Catholic student movements were in the front ranks. ${ }^{5}$

Achille Ratti, Vatican librarian, scholar, and Alpine mountain climber, was elevated to the papacy as Pius XI in 1922. Some speculate that Ratti was chosen to be pope because of his experience as the Papal Nuncio to Poland in 1920 where he had first-hand experience in dealing with Russian Bolshevism. Archbishop Ratti remained in Warsaw in order to encourage Polish Catholics as they faced a Soviet invasion. ${ }^{6}$ The period of Rat-

${ }^{3}$ Anthony Rhodes, The Vatican in the Age of the Dictators, 1922-1945 (London: Hodder and Stoughton, 1973), 50.

${ }^{4}$ Robert Wohl, The Generation of 1914 (Cambridge: Harvard University Press, 1979) 73; Whitney, Mobilizing Youth, 81.

\footnotetext{
${ }^{5}$ Rhodes, Age of the Dictators, 15.

${ }^{6}$ Anderson, Pope Pius XI, 40.
} 
ti's tenure as pope, 1922 to 1939 would overlap with the rise of totalitarian ideologies in Italy and Germany and despite his aversion to socialism; his greatest struggles were eventually with fascism. After his elevation to the papacy, Pius XI took immediate steps to restructure and centralize the loose-knit web of Catholic lay organizations and made the streamlined Catholic Action the centerpiece of his strategy for a re-Christianization of Europe. $^{7}$

During the same early years, Joseph Cardijn was attempting to work out a method to influence industrial proletarian youth in Belgium with the Christian faith. Cardijn also worked tirelessly on their behalf to improve their working conditions. While Pius XI understood the need to involve lay people in the apostolate of the hierarchy, Cardijn went a small but significant step further in recognizing the need to evangelize the working class with missionaries recruited from the working class themselves. "The working class must save the working class. Like must save like." In his famous phrase, "with them, by them and for them" (par eux, en eux et pour eux). ${ }^{8}$ Cardijn's genius was to hit upon the idea of developing these young workers into leaders and then deploy them as missionaries targeting their own social class and age cohort. ${ }^{9}$ Cardijn's approach bore a striking resemblance to Gramsci's call for a process of formation aimed at raising the consciousness of work-

${ }^{7}$ Ibid., 68 .

${ }^{8}$ Bedoyere, The Cardijn Story, 26.

${ }^{9}$ Oscar Cole-Arnal, "Shaping Young Proletarians Into Militant Christians: The Pioneer Phase of the JOC in France and Quebec,” Journal of Contemporary History 32.4 (Oct 1997): 510. 
ers and developing them into "organic" intellectuals (self taught intellectuals from the working class). ${ }^{10}$

The Pope and the working class priest met for the first time early in 1925 after Cardijn's movement had been condemned by the Belgian prelate in $1924 .{ }^{11}$ Cardijn went to Rome to appeal directly to Pope Pius XI. It was the Lenten season, and Cardijn was informed that it would be impossible to meet with the pope privately. Somehow he managed to maneuver himself into the pontiff's study. Michael de la Bedoyer describes their brief but meaningful conversation: "'What do you want?' [the pope] asked, wondering how this man had managed to evade those responsible for the privacy of the Holy Father," a terrified Cardijn just managed to blurt out, 'Most Holy Father, I want to kill myself in order to save the working masses."' "At last!" Pius XI is reported to have said. "Here's someone who talks to me of the masses, of saving the masses. Everyone else talks to me of the elite. What is needed is an elite in the masses, a leaven in the paste ... Not only do we bless your movement, we want it. We make it ours." ${ }^{12}$ Despite some of the radical innovations that Cardijn was bringing into working class youth ministry, his fledgling movement received the blessing and the protection of the Pope. ${ }^{13}$

10 Antonio Gramsci, Selections from the Prison Notebooks, reprinted in 2005 (New York: International Publishers, 1971), 7-9.

${ }^{11}$ Gerd-Rainer Horn, Western European Liberation Theology: The First Wave (1924-1959) (Oxford, New York: Oxford UP, 2008), 51.

${ }^{12}$ Bedoyere, The Cardijn Story, 66-67.

${ }^{13}$ Ana Maria Bidegain, "From Catholic Action to Liberation Theology: The Historical Process of Laity in Latin America in the Twentieth Century," working paper, Kellogg Institute for International Studies, (Notre Dame, IN, 1985), 6-7. 
Both Cardijn and Pope Paul XI became prime movers of the Catholic Action movement that began to expand rapidly from the mid-1920s through the Second World War, although Catholic Action had already been in existence since the late nineteenth century. Extensive scholarly studies have examined the role of Catholic Action in Italy, Spain, France, Canada, and several countries in Latin America. The early beginnings of Catholic lay organizations which eventually came to be described as the lower-case "catholic action" or "catholic social action" in the second half of the nineteenth century represented a defensive reaction to the loss of the coercive-instrumental power of the papacy over society. As the Vatican lost the strategic assistance of the state for enforcing its social influence, the Church developed a plan to mobilize a popular base and make more use of the press and lay organizations as a foundation for the restoration of Catholic Christian society." 14

Catholic Action: The General Italian Model.

In 1868, the Society of Italian Catholic Youth (Società della Gioventù Cattolica Italiana) was organized in Bologna, Italy, closely following the founding of the Vatican newspaper, Osservatore Romano (1860) and coinciding with plans for the first Vatican Council (1869). ${ }^{15}$ The new youth organization represented the first time lay people were the initiators of an effort to build up a national association for the defense of the Church.

\footnotetext{
${ }^{14}$ Hubert Jedin, Roger Aubert, and John Dolan, The Church Between Revolution \& Restoration, trans. Peter Becker (New York: Crossroad, 1981), 92; Horn, Western European, 38-39.

${ }^{15}$ (Translation: Federation of Italian Catholic University students) Luigi Civardi, Compendio di Storia Dell'azione Cattolica Italiana (Rome: Coletti Editore Roma, 1956), 65; Joe Holland, Modern Catholic Social Thinking: The Popes Confront the Industrial Age 1740-1958 (New York: Paulist Press, 2003), 50, 54. Note: Several student leaders of the FUCI went on to later become Prime Ministers of Italy such as Aldo Moro, president of the student movement from 1939 to 1942 and Giulio Andreotti, national leader of the FUCI from 1942 to 1944.
} 
The Society quickly gained the support of the ecclesiastical authorities and was soon sanctioned by a papal decree.

The emerging Catholic lay movement focused primarily on religious and doctrinal issues. Its activity was meant to be mainly educational and nonpolitical. Nevertheless, it was intended to have an indirect function of influence in the public sector and on the political sphere. The early congresses resulted in the organization of a loose federation of parochial societies of committed laypeople called the Opera dei Congressi e dei Comitati Cattolici. The annual meetings were organized by a committee, whose leaders were appointed by the pope. At the grass-roots there were parochial societies controlled by priests but made up of laypeople. Regional and diocesan committees were formed at the intermediate level. As noted earlier, the phrase "catholic action" was commonly used (without capital letters) to describe the variety of groups working under the Opera's parish and diocesan committees, and participating in the annual congresses. The first Catholic "university circles" (Circoli Universitari Cattolici) were formed in Milan in 1884 by Bishop Agostino Riboldi with the express purpose of countering atheism and anticlericalism in the universities. At the Fourteenth Italian Catholic Congress in 1896, the university circles were re-orgnaized and officially named the Federazione Universitaria Cattolica Italiana (FUCI, Italian Catholic University Federation). ${ }^{16}$

\footnotetext{
${ }^{16}$ Civardi, Dell'azione Cattolica Italiana, 79. Italian Catholic University Federation (author's translation) was the university branch of Catholic Action in Italy and focused on recruting university students to became Catholics.
} 
Since the nineteenth century, the Catholic hierarchy had considered liberalism and democratic pluralism to be ideological threats. ${ }^{17}$ A new perceived threat to the church now arose in the form of socialism among industrial and rural workers. The Catholic Church viewed socialism as a byproduct of anticlerical liberalism, and both liberalism and socialism to be the evil step-children of the Protestant Reformation. For the Italian Catholic movement, the question was which of the twin evils might be the greater threat—bourgeois liberalism or atheist socialism. Internal tensions soon arose within the Opera dei Congressi when a democratically-oriented Catholic left-wing came into conflict with the conservative traditionalists within the Catholic lay movement. ${ }^{18}$

Pope Pius X dissolved the Opera dei Congressi in 1904, when the conflict between pluralist democrats and traditional conservatives broke out into the open. $\mathrm{He}$ appointed trusted leaders to oversee its reorganized parts and established firm hierarchical control over its activities. ${ }^{19}$ In addition to propagating the Catholic social vision and labor organizations, Pius X set up an "Electoral Union" to guide Catholic participation in Italian parliamentary elections. Other national Catholic lay organizations recognized as part of Catholic Action were the Italian Catholic University movement

${ }^{17}$ Christopher Clark and Wolfram Kaiser, eds., Culture Wars: Secular-Catholic Conflict in Nineteenth-Century Europe (Cambridge: Cambridge Univresity Press, 2003), 40; Ana María Bidegain, Participacio'n y Protagonismo de las Mujeres en la Historia del Catolicismo Latinoamericano (Ciudad Autonoma de Buenos Aires: San Benito, 2009), 26.

${ }^{18}$ Gianfranco Poggi, Catholic Action in Italy (Stanford, CA: Stanford University Press, 1967), 18.

${ }^{19}$ Paul Misner, "Catholic Labor and Catholic Action: The Italian Context of Quadragesimo Anno," The Catholic Historical Review 90, no. 4 (October 2004): 11. 
(FUCI), the Catholic youth organization and the "Union among Catholic Women." ${ }^{20}$

Shortly before Italy entered World War I, Pius X's successor, Benedict XV (1914-22), further reorganized what was coming to be called "Catholic Action" (now with capitals). The general direction of the movement was entrusted to a committee elected by the council of the Unione Popolare (popular union). The first national youth organization for women known as the Gioventú Femminile Cattolica Italiana was founded in 1918 and focused on single women under thirty years of age. ${ }^{21}$

When Cardijn had explained his passion for helping working class youth, the pope gave his full blessing to the new young workers movement. ${ }^{22}$ Cardijn and Pius XI became permanent friends, and Cardijn was called upon to advise the pope on workers issues and occasionally helped draft papal statements on the lay apostolate. The movement rapidly grew in Belgium and soon began to expand internationally in France and Quebec. By 1935, the first International Congress drew together 100,000 participants from a number of different countries. ${ }^{23}$

The specialized Franco-Belgian Catholic Action, inspired by the example of Joseph Cardijn and his young Christian workers, developed a number of progressive innovations as it responded to competition from socialists and communists in its mission to reach young workers. The young communists tended to avoid recruiting students because

${ }^{20}$ Civardi, Dell'azione Cattolica Italiana, 120-121.

${ }^{21}$ Poggi, Catholic Action, 20; Bedoyere, The Cardijn Story, 123.

${ }^{22}$ Bidegain, "From Catholic Action to Liberation Theology," 7.

${ }^{23}$ Louise Bienvenue, Quand la Jeunesse Entre en Scene: L'Action Catholique Avant la Revolution Tranquille (Montreal: Les Editions du Boreal, 2003), 207; Aline Coutrot, "Youth Movements in France in the1930s," Journal of Contemporary History 5, no. 1, Generations in Conflict (1970): 29. 
of their elite class background and focused heavily instead on recruiting work-class youths thus putting them in direct competition with Cardijn. ${ }^{24}$ The mission of Cardijn's Juventud Obrera Chrétien (JOC), or Young Christian Worker's movement, was to reach proletarian youth in order to bring them into the Catholic faith. To accomplish this task, it was necessary for the JOC to discern the legitimate needs of working class youth and to find ways to respond to these needs more effectively than the socialist or communist youth movements. The unintended consequence of this competitive pressure was that the JOC occasionally moved slightly to the political left, developed greater autonomy for young lay leaders from hierarchical control and focused on social class as the prime organizational principle. ${ }^{25}$ Such was the working class orientation of the JOC, that the young Catholic workers were often accused of being communists by the more traditional sectors of Catholicism. ${ }^{26}$

In contrast, during these same years the Italian Catholic Action under Pope Pius XI faced growing political pressure and even violence from the Italian fascists. Mussolini demanded that Italian Catholic Action restrict its activities to the private devotional and liturgical sphere. ${ }^{27}$ In order to ensure the survival of Italian Catholic Action, the pope was forced to restructure Catholic Action several times in such a way as to limit lay autonomy

\footnotetext{
${ }^{24}$ Philip G. Altbach and Norman T Uphoff, The Student Internationals (Metuchen, New Jersey: The Scarecrow Books, 1973), 14.

${ }^{25}$ Oscar Cole-Arnal, "Shaping Young Proletarians into Militant Christians: The Pioneer Phase of the JOC in France and Quebec," Journal of Contemporary History 32.4 (Oct 1997): 510.

${ }^{26}$ Bidegain, "From Catholic Action to Liberation Theology," 94.

${ }^{27}$ Rhodes, Age of the Dictators, 50.
} 
and to strengthen the authoritive control of the Catholic hierarchy. Both the Pope's general Italian Catholic Action and Cardijn's specialized Franco-Belgian Catholic Action were exported to the Americas through transnational Catholic networks, and both exercised varying degrees of influence in other countries such as Brazil, Canada and Cuba. ${ }^{28}$

The specialized Catholic Action was also extended to include specialized movements focused on students, university youth, rural youth and young professionals. Although Italian Catholic Action also focused on youth, only two of several branches were youth oriented. Italian general Catholic Action also focused on adult men and adult women. ${ }^{29}$ Specialized Catholic Action, by way of contrast, arose with an almost exclusive concern to reach out to various demographic categories of youth, congruent with the development of a whole emphasis in advanced industrial countries on youth culture and generational change. ${ }^{30}$

The Catholic Church perceived itself to be threatened by multiple modern ideologies in the period leading up to and in between the two World Wars. Liberalism, nationalism, and anticlerical secularism had been the traditional enemies of Catholicism throughout the nineteenth century. ${ }^{31}$ In 1868 , Pope Pius IX convened the First Vatican Council

\footnotetext{
${ }^{28}$ Catholic Action youth began in 1928 in Cuba and 1931 in Canada. For Cuba, See J. Diaz, comp., Victorino: Hermano de la Salle: Fundador de la Juventud Catolica (Hermanos de la Salle) 5; for Canada see Bienvenue, Quand la Jeunesse, 58. Brazilian Catholic Action began in 1934 and the Catholic university movement (JUC) began soon after in 1937. Dom Cândido Padim, interview. Programa de Historia Oral, Centro de Documentação e Informação Científica (São Paulo, Brazil: Pontíficia Universidade Católica de São Paulo, 1990).

${ }^{29}$ Poggi, Catholic Action, 29; Emmet John Hughes, Report from Spain (Port Washington, N.Y.: Kennikat Press, 1947), 56.

${ }^{30}$ Edward L. Cleary, Crisis and Change: The Church in Latin American Today (Maryknoll, NY: Orbis Books, 1985), 4.
} 
and attempted to erect defensive barriers to the erosion of Catholic faith. Anticlericalism in France reached a fever pitch during the Dreyfus Affair at the turn of the century (18991906) and contributed to the eventual separation of Church and State in France. ${ }^{32}$ The growing loss of religious participation of the urban working masses in industrialized Europe created a new threat to the traditional social hegemony of the Catholic worldview. Various Popes, beginning with Leo XIII and his landmark encyclical, Rerum Novarum (1891), attempted to respond to the flight of the new urban proletarian class from Catholicism to socialist ideologies by addressing the "social question." Then, by the mid-1930s, the Church found itself engulfed in the "Terrible Triangle" of political conflict and persecution in Soviet Russia, revolutionary Mexico and the Spanish Civil War. ${ }^{33}$ One instrumental response to the multiple threats surrounding the church was the formation of multiple associations of Catholic lay people focused on influencing their respective social classes and social, demographic and professional milieus.

The plethora of diverse Catholic organizations for lay people was almost immediately reorganized and centralized under the new Pope and given much greater visibility. Pope XI became known as "the Pope of Catholic Action" because of the high priority he gave to the creation and establishment of Catholic Action organizations not

\footnotetext{
${ }^{31}$ Paul Lakeland, The Liberation of the Laity: In Search of an Accountable Church (New York: Continuum, 2003), 17-18.

32 The Dreyfus Affair was scandal that divided France. The French Catholic Church indentified itself with the anti-Drefusards and lost considerable credibility with French liberals as a result. The French law separating the church from the state was passed in 1905, in part influenced by the church's role during the Dreyfus Affair. Eric O. Hanson, The Catholic Church in World Politics (Princeton University Press, 1987), 42; Gordon Wright, France in Modern Times, 4th ed. (New York \& London: Norton, 1981), 246, 247.
} 
only in Italy but throughout the world. ${ }^{34}$ The Pope viewed the revived Catholic Action as the central element for a strategy aimed at a religious "Reconquista" or reChristianization of European society through the influence of mobilized Catholic laypeople.

\section{Pius XI: The "Pope of Catholic Action"}

The Italian model of Catholic Action that emerged from Pius XI's restructuring in the 1920s would largely remain in force in Italy with some minor adjustments until 1946. It was organized in four lay associations focused on adult men, adult women, young men, and young women. The actual four associations were those of Catholic men, of (male) youth, of university students (male: FUCI), and of women. The women's association was divided into university women, adult women, and the female youth organization. They were joined at the top, by a central committee (Giunta Centrale) that brought their presidents together with a few "assistants" from the clergy, all appointed by the Pope. Pius XI's "top-down" approach to Catholic Action was clearly authoritarian and became more so over time under pressure from Mussolini.

Catholic Action was to be primarily religious, but not necessarily private. Pius XI defined Catholic Action as the "participation of the laity in the apostolate of the hierarchy," meaning that it could not function like a political party or a labor union, since nei-

${ }^{33}$ Indre Cuplinskas, "Guns and Rosaries: The Use of Military Imagery in the French-Canadian Catholic Student Newspaper JEC.” Historical Studies 71 (2005): 5-6.

${ }^{34}$ Poggi, Catholic Action, 22. 
ther politics nor economic activities were the apostolic responsibility of the hierarchy. ${ }^{35}$

Nevertheless, rather than withdraw into private spirituality, the lay activists in the hierarchically-directed movement were to prepare the moral foundations for the re-

Christianization of society at the grassroots. Pius XI's vision for Catholic Action was intended to reestablish the moral hegemony of the Catholic Church rather than make room for social pluralism. The interwar intellectual climate in Europe viewed the "bourgeois" liberalism of western civilization as being in a severe crisis of moral decay. During the period between the two World Wars concepts of re-evangelizing Europe and establishing neo-Christendom become popularized by Catholic thinkers such as Jacques Maritain. ${ }^{36}$ There was little interest in Vatican circles for introducing liberal democratic concepts, lay autonomy or social pluralism into Catholic Action.

\section{Catholic Action versus Fascism}

As early as 1923 there was growing tension between Italian Catholic Action and Fascist youth organizations. ${ }^{37}$ The rise of Mussolini's Italian Fascism coincided with the tenure of Pius XI and his promotion of Catholic Action as a Catholic force for mobilizing

\footnotetext{
${ }^{35}$ Pius XI, "Ubi Arcano Dei Consilio," Encyclical letter on the peace of Christ in the kingdom of Christ (Vatican: December 23, 1922), Http://www.papalencyclicals.net/.; "Pio XI e Azione Cattolica," L'Osservatore Romano (January 3, 1923); Aurora G. Morcillo, True Catholic Womanhood, Gender Ideology in Franco's Spain (DeKalb, Illinois: Northern Illinois University Press, 2000), 140.

${ }^{36}$ Jacques Maritain (1882-1973) was a French Catholic philosopher and author of more than 60 books. He converted to Catholicism in 1906. Maritain was a prominent drafter of the Universal Declaration of Human Rights. He engaged in philosophy using Aristotle and Thomas Aquinas, as well as in aesthetics, political theory, and metaphysics. Maritain advocated what he called "Integral Humanism" in which he explored the idea of a new Christendom, rooted in philosophical pluralism, in order to find ways that Christianity could inform political discourse and policy in a pluralistic age. Maritain's political theory was an influential source of inspiration for the Christian Democratic movement. Jacques Maritain, Integral Humanism; Temporal and Spiritual Problems of a New Christendom, Translated by Joseph W. Evans. (Notre Dame, Ind.: University of Notre Dame Press, 1975).
} 
Italian youth and using them to influence Italian society. There was a brief attempt to organize members of Catholic Action by occupation or social class (along the lines of Cardijin and the Franco-Belgian specialized Catholic Action) which immediately elicited a fiercely hostile reaction from the Fascist regime. ${ }^{38}$ The Fascist party and Italian Catholic Action were ideological competitors for the allegiance of Italian youth. To use business terminology, they were competing for the same ideological "market share." Mussolini viewed the popularity of Catholic Action groups with suspicion. The presence of an autonomous nation-wide and transnational organization outside the control of state and party posed a threat to his intention to control all public activities and mass organizations. ${ }^{39}$ Pius XI used the opportunity to bring about centralizing reforms in Catholic Action in 1923, and to strengthen clerical control of the lay associations at the Diocesan level. $^{40}$

Fascism consciously encouraged the use of symbols, myth, and ritual to cultivate the appearance of a type of "fascist" secular religion. As in any other religion, ritual and symbol served to bind believers to the cult. Fascism communicated its myths through its own type of secular liturgy that was intended to bring the popular masses into the worship of the nation. Ritual expressed the national will and transformed politics into a

37 “Conflitto Nazional-Fascista,” L'Osservatore Romano, January 3, 1923.

38 “Pope Condemns Idea of Fascist State; Lauds Mussolini," New York Times, December 21, 1926.

39 Tracy H. Koon, Believe, Obey, Fight: Political Socialization of Youth in Fascist Italy (Chapel Hill, North Carolina: University of North Carolina Press, 1985), 122-123.

40 “Azione Cattolica: La Prima Aduanza Plenaria Della Nuova Giunta Diocesana di Milano." L'Osservatore Romano (January 11, 1923). 
drama. The role of the regime was to build upon traditions familiar to the masses by using ritual to create new traditions that would inspire and hold the people. ${ }^{41}$

One example of the role of symbolic and quasi-religious myth-building was the changing of the calendar from Christian dating, counting from the birth of Christ, to a Fascist calendar, counting the dates from the Fascist March on Rome. The Fascist youth magazine, the Gioventù Fascista (Fascist Youth), directed by the fanatical Mussolini loyalist Achille Starace, dated each issue in 1935 with the Anno XIII, or in other words, year 13 of the Fascist era. ${ }^{42}$ After the successful invasion and victory over Ethiopia in 1935, another dating system was added to the fascist calendar. The new fascist Empire dated its existence from 1935 in Roman numerals. For example, the front cover of the October 30, 1935 issue of Givoentù Fascista, displayed an image of a young bare-chested Italian commemorating the March on Rome on October 28, 1922, the conquest of Ethiopia and the commencement of the new Impero in May of Anno XIV (1936). ${ }^{43}$ Another indication of the semi religious nature of Italian fascism is found in the regular section called Credere nelle parole del Duce in each issue of Givoentù Fascista, The title, translated into English, was "Believe in the Word of the Duce." This was a collection of quotes from Mussolini and was presented in such a way as to remind one of the 'Word' of God or of Jesus. ${ }^{44}$ This brought to mind similarities with the Christian

\footnotetext{
${ }^{41}$ Koon, Youth in Fascist Italy, 27.

42 "Credere, Obedecere, Comattere!" Gioventù Fascista, September 1935; Koon, Youth in Fascist Italy, 28.

43 “Continuaremo a Tirare Diritto!” Gioventù Fascista, October 1937.

44 “Credere Nelle Parole del Duce." Gioventù Fascista, September 1935.
} 
scriptures such as in the Gospel of John "Many more believed because of His word"45 and from the Psalms: "Then believed they his words; they sang his praise."46

The use of mystical and religious discourse by the Fascists was part of Mussolini's strategic use of a mythical element to move the masses. His linguistic style made frequent use of rhythmic and tonal variations, hyperbole, imagery and metaphor. Myths were conveyed in phrases, sayings and slogans on the walls of offices, factories, barracks, party headquarters, and railroad stations; on the radio; and in textbooks, cartoon strips, and newspaper headlines. The official propaganda used a vocabulary taken from both the military and the church that emphasized politics as a religious crusade in a heroic national quest. Martial words such as "struggle," "courage," "heroism," "discipline," and "war," were commonly used to conjure up images of strength and implacable force. Fascism was not only like an army but also a religious cult. A religious lexicon hammered home this message repeatedly, using words like "martyr," "sacrifice," "rite," "altar," "redemption," "communion," "mission," "commandment," and "hierarchy." Fascism was a "sacred" or "holy" struggle; war the "supreme sacrifice." ${ }^{47}$

Of course the church used many of the same words listed above as part of its sacred discourse, but a word frequency study of Pius XI's discourse in his Encyclicals from 1922 to 1939 also reveals many military words such as struggle (27), soldier/s (27), strong-strength-strengthened (102), virtue (105), duties (83), exercises (66), obedience

\footnotetext{
${ }^{45}$ John 4:41 from the New American Standard Bible (NASB).

${ }^{46}$ Psalm 106:12 12 from the American Standard Version (ASV).

${ }^{47}$ Koon, Youth in Fascist Italy, 11.
} 
(63), order (60), devotion (51) enemies (49), strive (44), discipline (39) service (33), command (29). Although it cannot be said that military imagery dominated the Pope's discourse in the Encyclicals, military metaphors do appear on a regular basis. Clearly, among myth, religious discourse, ideology, militancy and education, Fascism and the Italian Catholic Church had many points of overlap and potential conflict. ${ }^{48}$

Italian Fascism and the Italian Catholic Church clashed severely over education. The fascist party viewed the church as a competitive threat in the fascist effort to win the absolute loyalty of Italian youth. The church had always placed a high priority on educating the youth as a way of instilling religious values and reinforcing their loyalty to the teachings of the church. In the last quarter of the nineteenth and early years of the twentieth century, there was growing conflict between the Catholic Church and secular states over the control of educational system. ${ }^{49}$ In response to the education crisis, the Vatican encouraged the development of Catholic Action and its youth oriented subsidiaries as an alternative approach to influencing society. Catholic Action formed parish-focused social clubs for young males and females and established social circles for young Catholic students in both secondary schools and universities, thus maintaining an avenue for influencing youth in secular society. ${ }^{50}$ Mussolini's government intended to do

48 Thirty two of Pope Pius XI's Encyclicals are available for viewing or downloading on the Vatican web site. These were loaded into NVivo software in order to run word frequency analysis reports. Pius XI, Encyclicals (Rome: Vatican, 1922-39), Http://www.papalencyclicals.net/.

${ }^{49}$ Paul Misner, "Catholic Labor and Catholic Action: The Italian Context of Quadragesimo Anno," The Catholic Historical Review 90.4 (Oct 2004): 660.

${ }^{50}$ Misner, "Catholic Action,” 660. 
much the same thing in order to train a generation of youth in the totalitarian fascist mentality. ${ }^{51}$

The formation of Catholic Action lay-led groups was an approach to social influence from the ground up as opposed to the more traditional, state-centered, top-down approach. The New York Times reported in June of 1931 that the "whole basis of conflict between the Holy See and Fascism revolves around the question of education of youthwhose voice should be sovereign in this realm, that of the Church or the Fascist State?",52 The writer went on to observe that fascism entailed the subordination of the individual to the state in contrast to the liberal-democratic belief that "society is for the individual." The Pope, speaking on behalf of the church, emphasized that the basic unit of society was not the state but rather the family and the person. ${ }^{53}$

The pope published a letter at the height of the controversy between the Fascist regime and the Vatican in December of 1929. In no uncertain terms, Pius XI made it clear that the family held the first rank of responsibility for the education of its youth, followed closely by the church. ${ }^{54}$ According to Pius XI, it was the exclusive right as well as the indispensable duty of the church, to watch over the education of children, in all

${ }^{51}$ Koon, Youth in Fascist Italy, 8.

${ }^{52}$ Elizabeth Camille Brink, "Clashing Aims of Fascism and the Vatican: Education of Youth the Basic Factor Now Going on in Rome,” New York Times, June 7, 1931.

${ }^{53}$ Ibid.

${ }^{54}$ Pius XI, Divini Illius Magistri, Encyclical Letter on Christian Education Vatican Web site, December 21, 1929, http://www.papalencyclicals.net/. 
institutions, public or private, not only in religious instruction, but also in regard to every other branch of learning. ${ }^{55}$

The Fascist party could not tolerate an ideological rival with the broad popular base of support that Catholic Action enjoyed in the public sphere. Mussolini began to bring violent pressure to bear on Catholic Action groups throughout Italy to restrict themselves to devotional and religious activities. The pressure included stoning, anti-Catholic riots and acts of vandalism on Catholic Action offices throughout Italy. ${ }^{56}$

The Fascist party leaders were suspicious of the activities of Catholic Action and its youth, student and university wings. They accused the organization of harboring former members of the Catholic Popular party and of carrying out social programs that competed with the fascist welfare programs. ${ }^{57}$ They directed their violent harassment especially against the Gioventù Cattolica (Catholic Youth) and against the Federazione Universitana Cattolica Italiana (FUCI, Italian Catholic University Federation) ${ }^{58}$ and the specialized university sections established in 1926. "The so-called war against the 'politi-

${ }^{55}$ Pius XI, Divini Illius Magistri, 23.

56 “Fascists Trample Portrait of Pope; Vatican is Guarded.” New York Times, May 28, 1931.

${ }^{57}$ The PPI, Partido Populari Italiano was founded in 1919 by a Catholic priest, Luigi Sturzo. It was the second largest party in the early 1920s and was one of the few political actors capable of resisting Italian fascism. The PPI was banned by the fascists in 1924-25 and Sturzo went into hiding and exile. In exchange for an agreement with Mussolini to the Lateran Treaty (which recognized the Vatican as a sovereign state within Italy), the Pope eventually dropped his support for the PPI. The PPI was influential in the eventual rise of the Christian Democratic parties.

${ }^{58}$ The Gioventù Cattolica was the general Catholic Youth branch of Italian Catholic Action while the Federazione Universitana Cattolica Italiana (FUCI) specially focused on university youth. 
cal activities' of the Catholic Action was but another round in the struggle for custody of the child." ${ }^{59}$

The conflict over the FUCI was especially intense in 1931 because control of the intellectual elite was essential for both the church and the fascist regime. Violence erupted, and the offices of the FUCI and the Gioventù Cattolica were broken into and sacked by Gioventù Universitaria Fascista (GUF, Fascist University Youth) members. ${ }^{60}$ The FUCI headquarters in Rome was put under constant surveillance and its files searched for incriminating evidence. Members of the Catholic youth groups were beaten, books burned, statues broken, religious ceremonies disturbed even in churches, and parodies of Catholic rites staged. In the streets processions of young fascists chalked offending slogans on walls and publically ridiculed and mocked the Pope and the various youth and university organizations of Catholic Action. ${ }^{61}$

The vicious attack on Catholic Action groups by Fascists squads and Fascist university youth set the stage for another of Pope Pius XI's Encyclicals. ${ }^{62}$ The Pope published Non abbiamo bisogno (On Catholic Action in Italy) in July of 1931, an unusually direct letter written in Italian, rather than Latin, and divided into two parts. The first part was a severe indictment of the Fascist regime's "false accusations" against Catholic Action and a condemnation of the persecution against the church. The Pope declared that the

\footnotetext{
${ }^{59}$ Koon, Youth in Fascist Italy, 130-31.

${ }^{60}$ The Gioventù Universitaria Fascista (GUF) was the Fascist university organization that directly competed with the Catholic FUCI for the loyalty and allegiance of university youth.

${ }^{61}$ Koon, Youth in Fascist Italy, 134.
} 
regime's real intention was to "tear away from Catholic Action and so from the church, the young — all the young." In the second part Pius reaffirmed the church's divine mandate to educate children and rebuked the regime's efforts "to monopolize the young ... for the sole and exclusive benefit of a party and of a regime based on an ideology that clearly resolves itself into a veritable pagan worship of the state." ${ }^{63}$

Inflammatory rhetoric continued in the press for several more weeks, but eventually both sides realized that continued provocation of the conflict would benefit no one. Negotiations to resolve the conflict began at the end of July. The negotiators reached an agreement in September 1931. Catholic Action was again recognized by the government, but only in a "diocesan" form. The lay leaders of Catholic Action and their clerical advisors were to be chosen by bishops rather than elected by members. Catholic Action was restricted from any kind of involvement with politics; its specialized professional groups remained dissolved. The youth organizations of Catholic Action were not allowed to display any banners or flags other than the national tricolor at meetings. These groups were also forbidden to organize any kinds of sports events. Simply put, they were to become nothing more than religious discussion groups. ${ }^{64}$

In order to avoid further conflict with state authorities, the Pope initiated a reorganization of Italian Catholic Action in 1932. Rather than being structured around a focused organizational concept, as was the case with the specialized Franco-Belgian

\footnotetext{
${ }^{62}$ Pius XI, Non Abbiamo Bisogno, Encyclical letter on Catholic Action in Italy, Vatican Web site, June 29, 1931, http://www.papalencyclicals.net/.

63 "Pope in Encyclical Denounces Fascisti and Defends Clubs." New York Times, July 4, 1931.

${ }^{64}$ Koon, Youth in Fascist Italy, 136.
} 
branch, Italian Catholic Action became even further structured around the diocese and the local parish. ${ }^{65}$ Italian Catholic Action fell directly under the control of the bishops of each diocese and placed authority with the clerics who were formerly called 'assistants.' The restructuring further curtailed the autonomy of lay leaders and became the 'general' Catholic Action or the Italian model that would be emulated and exported through mission work in Catholic countries around the world.

The 'Specialized' Franco-Belgian Model of Catholic Action

The situation that Catholic priests such as Joseph Cardijn faced in northern France and Belgium was very different than the issues facing Catholicism in Italy. Catholic Action in France and Belgium emerged in a different socio-political and cultural context than Catholic Action in the Mediterranean countries of Italy and Spain. According to scholar Gerd-Rainer Horn, specialized Catholic Action found fertile soil in the more advanced industrial nations because these were the regions suffering from the consequences of industrial capitalism earlier than other portions of Catholic Europe. Cardijn's native country, Belgium, was the first continental European country to experience heavy industrialization. ${ }^{66}$ As mentioned previously, rapid industrialization and urban growth led to a rapidly growing proletarian class that was almost entirely de-Christianized and alienated from the influence of the Catholic Church. The great challenge for the Franco-Belgian Catholic lay associations in the interwar period was to find a legitimate and effective response to the needs and concerns of young urban workers. Whereas the main ideological

\footnotetext{
${ }^{65}$ Poggi, Catholic Action, 25.

${ }^{66}$ Horn, European Liberation Theology, 33.
} 
competitor for Italian youth was fascism, the Franco-Belgian Catholics found themselves competing with socialists and communists for the hearts and minds of young proletarians in the context of democratic-pluralist societies. French Fascism, in the form of the rightwing nationalist movement, Action Française, had been condemned by the Pope in $1926 .^{67}$

Although the majority of French Catholics were anticommunist in the 1930s, there was an important minority group of Catholic intellectuals who were open to critical engagement and dialogue with Marxists. The French Communist Party attempted to reach out to Catholics in the main tendue (extended hand) of the Popular Front in 1936. Although only a small minority responded, the flood of anticommunist publications of the Church was reduced to a trickle as the geopolitical threat of Soviet Communism appeared to recede and was replaced by the looming threat of the German Nazis. The perspective of this group of French Catholic intellectuals was represented in the Catholic journal Esprit, which first appeared in Paris in October 1932. These French Catholic thinkers were influenced by the revisionist Marxism of Georges Sorel, the libertarian socialism of Pierre-Joseph Proudhon, and the philosophy of Henri Bergson. The writers of Esprit identified themselves with a theoretical Catholic "Third Way" which was pluralist and personalist and claimed to go neither Left nor Right but straight ahead. ${ }^{68}$

${ }^{67}$ Hannah Arendt, The Origins of Totalitarianism (San Diego, CA: Harcourt, 1979), 92, 120; Michael Kelly, "Catholicism and the Left in Twentieth-Century France," in Kay Chadwick, ed., Catholicism, Politics, and Society in Twentieth-Century France (Liverpool, U.K.: Liverpool University Press, 2000), 146.

${ }^{68}$ David Curtis, "True and False Modernity: Catholicism and Communist Marxism in 1930s France," in Catholicism, Politics, and Society in Twentieth-Century France, ed. Kay Chadwick (Liverpool, U.K.: Liverpool University Press, 2000), 75, 81; Bidegain, Participación y Protagonismo, 13. 
While general Catholic Action in Italy remained focused primarily on piety and liturgy at the parish and diocesan levels, in the mid-1920s Franco-Belgian specialized Catholic Action began to restructure itself around an aggressive mission to recruit young proletarians on the basis of social class. ${ }^{69}$ A favorite saying of the early "militants" of specialized Catholic Action was that they were to carry out their apostolic mission through "l'évangélisation du milieu par le milieu," which translated meant, "evangelism of the milieu, by the milieu." ${ }^{70}$ The idea was that in order to reach young proletarians, highly committed young Catholic workers must go into the working class milieu and work alongside the unchristianized working youth, in order to recruit or evangelize these secularized urban working youth for Catholic Action. ${ }^{71}$

Specialized Catholic Action was composed of a variety of different types of lay organizations, often with differing goals and methods, and focused on targeting different social groups for apostolic influence. The most innovative form of specialized Catholic Action, and the one that served as the model for all of the others, was Cardijn's own group called the Young Christian Workers (Jeunesse Ouvrière Chrétienne - JOC). The JOC movement continued its development, principally in France alongside the prêtres ouvrières (worker priests) in the 1930s and 1940s, under the intellectual influence of the

${ }^{69}$ Bidegain, "From Catholic Action to Liberation Theology," 6-7.

${ }^{70}$ Pierre Pierrard, Michel Launay, and Rolande Trempé, La JOC. Regards d'Historiens (Paris: Editions Ouvrières, 1984), 21.

${ }^{71}$ Oscar Cole-Arnal, "Shaping Young Proletarians into Militant Christians: The Pioneer Phase of the JOC in France and Quebec," Journal of Contemporary History 32.4 (Oct 1997): 510; Aline Coutrot, "Youth Movements in France in the1930s," Journal of Contemporary History 5.1, Generations in Conflict (1970): 28. 
French Catholic philosopher Jacques Maritain, and the Catholic theologians of the nouvelle théologie, Yves Congar, Henri de Lubac and Marie Chenu. ${ }^{72}$ Nouvelle theologie emphasized a renewal of traditional Catholicism by an opening to the real world and was at many points congruent with the specialized Catholic Action movements.

The JOC was given official recognition by Pope Pius XI in 1925 and grew rapidly in Belgium, France and the French-Canadian province of Quebec. ${ }^{73}$ Designed to reach the young industrial proletarians, the JOC was one of Catholicism's most innovative efforts to reach people at society's margins. The JOC attempted to influence workers through its militant young missionaries, themselves recruited from among the working class and mobilized into the industrial milieu itself. The JOC focused on intensive character formation of its militants in order to maintain their vital spiritual connection with the church in order to maintain their effectiveness as militant urban missionaries and to prevent them from being recruited by socialist or communist youth movements. ${ }^{74}$

The Jeunesse Ouvrière Chrétienne (JOC) grew rapidly in France in an increasingly tense ideological environment where the new interwar ideological movements competed fiercely for the hearts and minds of working-class youth. After 1926, the JOC was especially successful in its Christianizing and pedagogical mission to

\footnotetext{
${ }^{72}$ Luiz Alberto Gómez de Souza, Do Vaticano II a um novo concílio?: o olhar de um cristão leigo sobre a Igreja (São Paulo, Edições Loyola, 2004), 63; Scott Mainwaring, The Catholic Church and Politics in Brazil, 1916-1985 (Stanford, CA: Stanford UP, 1986), 118. Nouvelle Theologie (New Theology) refers to a school of theology among Belgian, French and German Catholics in the middle of the twentieth century that advocated a 'return to the sources' of the Christian faith: namely, scripture and the writings of the church fathers as a means of reforming the Catholic Church. The movement was characterized by openness to dialogue with modernity.

${ }^{73}$ Whitney, Mobilizing Youth, 81.
} 
the "Red Belt" of working class and communist neighborhoods encircling Paris. ${ }^{75}$ In 1928, the French Communist youth identified the Catholic Jocists as their "most dangerous adversaries." ${ }^{, 76}$ By the mid- to late-1930s, the Jocistes of France numbered in excess of 65,000 young women and men, and their chief newspaper, Jeunesse Ouvrière, had a circulation of approximately 270,000 readers. ${ }^{77}$ When the Second World War erupted, the French Jeunesse Ouvrière Chrétienne was the most important working-class youth group in the nation. The JOC was the pioneer among the loose-knit collection of lay-led organizations that formed specialized Catholic Action (SCA) and developed several innovative practices that eventually distinguished the specialized Catholic Action from the older Italian model of general Catholic Action that continued to be predominant in Italy and Spain in the 1930s.

Specialized Catholic Action (SCA) soon spread from Belgium to France and Quebec and quickly influenced the development of student and university movements, variously called Jeunesse Etudiant Catholique (JEC) and/or Jeunesse Universitaire Catholique (JUC). ${ }^{78}$ The SCA (worker or student) was organized as a sodality with a tendency toward more militancy, stronger and more independent lay leadership, and a more

\footnotetext{
${ }^{74}$ Feliciano Monteiro Garcia, La Acción Católica y el Franquismo. Auge y Crisis de la Acción Católica Especializada (Madrid: UNED Ediciones, 2000), 30.

${ }^{75}$ Whitney, Mobilizing Youth, 83.

${ }^{76}$ Ibid., 71.

77 Aline Coutrot, "Youth Movements in France in the 1930s," Journal of Contemporary History 5.1, Generations in Conflict (1970): 25. See also Laura Lee Downs, Childhood in the Promised Land: Working-Class Movements and the Colonies de Vacances in France, 1880-1960 (Durham and London: Duke University Press, 2002), 68.
} 
centralized organizational focus than the older Italian model of general Catholic Action. Thus, specialized Catholic Action tended to function with greater autonomy from the clerical hierarchy at the diocesan and parochial levels. Michael Gauvreau, discussing specialized Catholic Action in Quebec, astutely observes that "The idea of grouping young people in associations established according to social function, rather than geographic residence, constituted a decisive break with older Catholic patterns of religious endeavor that had historically been centered on the local parish." ${ }^{, 79}$ The break with tradition also coincided with a rising youth consciousness that demanded greater autonomy from elders and authority figures. ${ }^{80}$

The specialized groups of Catholic youth were focused more on missionary outreach on the basis of social class or profession than on providing liturgical or devotional support for the local parish or diocese. Specialized Catholic Action was characterized by a quasi-military type structure -- members were often referred to as militants -- and would eventually adopt an approach toward modernity anticipating the perspective of the Second Vatican Council (1962-1965), ${ }^{81}$ representing the most significant attempt at reform

${ }^{78}$ Indre Marija Cuplinskas, "From Soldier to Citizen to Prophet: A Study of the Spirituality of the Jeunesse Etudiante Catholique's Newspaper 'JEC/Vie Etudiante' (1935--1964),” (PhD diss., University of St. Michael's College, 2006), 23.

${ }^{79}$ Michael Gauvreau, The Catholic Origins of Quebec's Quiet Revolution, 1931-1970 (Quebec: McGill-Queens University Press, 2005), 17.

${ }^{80}$ Coutrot, "Youth Movements," 26.

${ }^{81}$ The Second Vatican Council (1962-1965) was called at the initiative of Pope John XXIII in order to address the Roman Catholic response to the modern world. Vatican II advocated openness to modernity and stood in contrast to the First Vatican Council (1868-1870) which was highly critical of modernity. It was held in St. Peter's Basilica in the Vatican. Pope John XXIII first suggested the idea of convening the Council in January of 1959, shortly after assuming office. He said that it was time to open the windows of the Church to let in some fresh air. 
and renewal of the Church since the sixteenth century. ${ }^{82}$ Several scholars have ranked the specialized Catholic Action movement and related Catholic lay movements of the twentieth century with historico-religious movements such as Ernst Troeltsch's two massive case studies - medieval Christendom and Anglo-Saxon Puritanism in England and the United States - as unique moments of potentially genuine world-transforming Christian movements. ${ }^{83}$

Formation Method: See-Judge-Act

A significant innovation developed by Cardijn and the JOC was a formative training method often referred to as the revision of life--or the See-Judge-Act method--which differed from the general Italian Catholic Action's traditional use of "study circles" to train their members. One of the primary differences was that study circles took the liturgy and church doctrine as their point of departure, whereas the revision of life often tended to focus first on the liberationist application of scripture to social and economic realities in search for pragmatic solutions to real life problems.

Specialized Catholic Action utilized the See-Judge-Act method as a means of forming a critical social awareness or consciousness in young student members. Although there was some similarity between the SCA methods to Marxist analysis, Edward Cleary traces the See-Judge-Act method back to St. Thomas Aquinas. ${ }^{84}$ The See-Judge-Act

\footnotetext{
${ }^{82}$ Monteiro Garcia, La Acción Católica, 10. The Council of Trent was called in 1545 and lasted until 1563 in response to the Protestant Reformation. Trent represented the Catholic Counter-Reformation.

${ }^{83}$ John A. Coleman, An American Strategic Theology (New York: Paulist Press, 1982), 42.

${ }^{84}$ Cleary, Crisis and Change, 4.
} 
approach to leadership formation involved a simple three step process of analysis. The first step, "see" involved a fresh reading of the scriptures while observing the social milieu around the student; such things as poverty and oppression were to be interpreted in the light of the scriptures and the social teaching of the church. The second step, "judge" could also be translated as discernment or evaluation. The students were trained to critically apply the scriptures (and as time went on, social science methods) to the social problems. JEC was very careful not to fall into simply theorizing about social problems; all seeing and judging was intended to result in the third step, act.

The three-step method focused first on careful observation of concrete reality (including social and economic factors) and then moved to the application of analysis of these realities, and finally resulted in concrete action based on the observation and analysis. From the beginning, the specialized movements emphasized the importance of concrete action rather than abstract theorizing. ${ }^{85}$ The young workers and young students groups of specialized Catholic Action also emphasized the importance of accompanying religious and devotional activities with proactive social action on behalf of workers and the rural poor. The "See, Judge, Act" process was an enduring strategy of the university organizations for the formation of the world views of the JEC and JUC student leaders even through all of the changes of the 1960s.

The change in methodology of the young Catholic workers and students had a long term influence over the concept of the secular apostolate as well as the specific role

\footnotetext{
${ }^{85}$ Mainwaring, “A JOC,” 38.
} 
of the Catholic Action militants. ${ }^{86}$ The See-Judge-Act method was adapted from the Catholic worker movement and implemented as the favored way of training new militants in many Catholic university movements in Latin America. The inspiration of the specialized Catholic Action movements was characterized above all by missionary zeal combined with a pragmatic, real-world action perspective. Young Catholics sought to take the Christian message into the most de-Christianized secular public spaces such as factories and universities. The SCA mobilized young adults to a militant struggle for a transformation of society along the lines of the social teaching of the Catholic Church. ${ }^{87}$

\section{Catholic University Student Movements}

Within specialized Catholic Action, students and universities were given the highest priority by the Catholic hierarchy. The university, especially in the earlier part of the twentieth century, was the front line of ideological contestation between traditional religious authority and encroaching secular modernism, especially in Mediterranean Europe and Latin America. Specialized Catholic Action targeted young men and women for recruitment and indoctrination, most often by their peers. Following the example of Cardijn's Young Christian Workers, Catholic student groups were formed in Belgium and France in the early 1930s and soon spread to Quebec and several countries in Latin America. In France, Belgium and Quebec these movements were called the Jeunesse Etudiant Catholique or JEC (Young Catholic Students). In Spanish or Portugueselanguage countries such as Cuba and Brazil, they were more frequently referred to as the

\footnotetext{
${ }^{86}$ Monteiro Garcia, Acción Católica, 30.

${ }^{87}$ Coutrot, "Youth Movements," 27. The "secular apostolate" was a phrase denoting the calling to missionary work to reach people in secular society.
} 
JUC or the Juventude Universitario Catolica (Catholic University Youth) and the "JEC" was reserved specifically for secondary education groups. ${ }^{88}$

The decade from 1925 to 1935 saw rapid growth of youth-oriented organizations in French-speaking Europe such as the Jeunesses Patriotes (Patriotic youth), Jeunesses Communistes (Communist youth), Fédération Nationale des Jeunesses Démocrates Populaires (National Federation of Democratic Youth). There were also scouting groups, social action groups (equipes sociales), Peace Volunteers, the Companions of St. Francis, the French youth hostels association and many other types of youth organizations. ${ }^{89}$ Because of the rapid appearance and numbers it seems unlikely that the emergence the new youth associations may be attributed to mere chance.

The growth of diverse kinds of youth movements reflected a generational transition as young people were becoming self-aware as a distinct and separate segment of society. These young people were experiencing the need for autonomy and free expression, and were at the same time, seeking to break loose from a restrictive generational framework in order to determine their own future. One scholar, commenting on the Catholic student movement in French-speaking Canada, goes so far as to describe the sudden emergence of vibrant Catholic youth movements as a "generational divorce. ${ }^{~} 90$ The generation of youth emerging under the looming shadow of World War II

${ }^{88}$ Luiz Alberto Gómez de Souza, "Aventuras Pelas Americas," (Rio de Janeiro: Boletim Nacional, 1957): 24, in Miami: Department of Religion, Florida International University, Bidegain Papers; Emanuel De Kadt, "Religion, the Church, and Social Change in Brazil," The Politics of Conformity in Latin America, Ed. Claudio Veliz (London and Oxford: Oxford UP, 1970), 210.

\footnotetext{
${ }^{89}$ Coutrot, "Youth Movements," 25.

${ }^{90}$ Bienvenue. Quand la Jeunesse, 76.
} 
sought to define itself in sharp contrast to the previous "failed" generation of the First World War, which had precipitated the Great Depression. ${ }^{91}$ In the general atmosphere of foreboding regarding 'liberal' Western civilization, there was intense ideological competition among groups such as Soviet communists, German national socialists, Italian fascists, Spanish anarchists and Catholics everywhere to recruit the younger generation and to indoctrinate them with their corresponding ideological values. ${ }^{92}$

From 1935 until the start of the war, the specialized Catholic Action youth movements experienced a surge in membership. In France alone the number of youth participating in the Young Christian Workers (JOC), Catholic students (JEC) and Catholic farmers groups (JAC) grew to at least 200,000 members by one estimate. ${ }^{93}$ There was also rapid growth in most all youth-oriented organizations including Protestant, socialist and fascist youth organizations. The common factor in most of these youth groups, including the Catholics, was the fact that they were aimed at all social classes and all regions, thus helping to break down regional and class barriers and to permit a youth consciousness to begin to form at national and international levels. The social mixing was carried beyond France and Europe because of international bodies such as the Communist Youth International, World Scouts, the International JOC, YMCA, and Pax Romana, which encouraged transnational contacts with young foreigners and the strengthening of links between the youth of different nationalities.

${ }^{91}$ Robert Wohl, The Generation of 1914 (Cambridge, Mass.: Harvard University Press, 1979), 80.

${ }^{92}$ Downs, Childhood, 68. Philip Altbach noted that students are particularly open to ideological appeals due to student idealism. Altbach, "Student Politics," 649.

${ }^{93}$ Coutrot, "Youth Movements," 29-30. 


\section{Catholic Action moves out of Europe to other countries.}

One response of the church to the anticlerical and liberal-nationalist attacks against Catholicism at the end of the nineteenth century was a vigorous burst of missionary energy directed toward the developing world. In the view of some scholars, Catholicism compensated for its decline in Western Europe through vast missionary outreach, particularly to peripheral areas that were part of the Western European colonial empires ${ }^{94}$ During the pontificate of Pius XI, the Vatican made the growth and spread of Catholic Action a high priority throughout the western civilization, especially in traditionally Catholic countries situated around the Spanish and Portuguese Atlantic rim. Numerous European priests moved to North and South America as missionaries. Depending upon their country of origin, these missionary-priests tended to reproduce their previous experience with Catholic Action. Italian and Spanish priests were predominant in Cuba, bringing with them their familiarity with the rather authoritarian Roman-style Catholic Action. Belgian and French priests moved to Canada where the relatively more autonomous specialized Catholic Action took root. Soon French-Canadian priests joined the French and Belgian missionaries moving south to Latin America, where they encouraged the development of specialized Catholic Action. Brazil, in particular, became the host to numerous Belgian, French and French Canadians who were eager to organize young students and workers into specialized Catholic Action associations. The founder of the $\mathrm{Cu}-$

\footnotetext{
${ }^{94}$ Holland, Modern Catholic, 204.
} 
ban Catholic youth was himself a French priest who moved to Quebec in 1904, after the expulsion of his religious order from France, before arriving in Cuba as a missionary. ${ }^{95}$

Quebec often acted as an intermediate stepping stone between Franco-Belgian Catholicism and the churches in Latin America. One of the key influencers of the Brazilian Catholic Action student movement, Father Romeu Dale, was influenced in the early stages of the formation of specialized Catholic Action by the arrival in São Paulo during the early 1940s of two French-Canadian Dominicans who had previous experience with the JOC in Quebec. ${ }^{96}$ The form of Catholic Action implanted in Quebec was the primarily specialized Catholic Action, after 1930, heavily influenced by Joseph Cardijn's Young Christian Workers and the Young Catholic Students in France. One of the key leaders of the Brazilian JUC, Luis Alberto Gomez de Souza, traveled to Montreal after a Pax Romana Congress in El Salvador and wrote in the Brazilian JUC national bulletin about the close similarities he noted between the student movements in Quebec with the Brazilian Catholic university movement. ${ }^{97}$

${ }^{95}$ Agustín Arnaud, known as "Hermano Victorino," left France twenty year before Father Cardijn developed specialized Catholic Action and started the young Christian Workers movement. Although he was French, his formative years were influenced by traditional, anti-modern Catholicism that was predominant at that time in France. Alfredo A. Morales, Hermano Victorino: Itinerario Evangélico (Santo Domingo, República Dominicana: Amigo del Hogar, 1994), 25; Gordon Wright, France in Modern Times, 4th ed. (New York \& London: W. W. Norton \& Company, 1981), 257.

${ }^{96}$ Souza, $A$ JUC, 87 and 96.

${ }^{97}$ Souza, “Aventuras Pelas Americas,” 24, Note: Pax Romana was an international organization of Catholic intellectuals and students that was started between the World Wars in the hope of promoting peace. Its headquarters was located in Fribourg, Switzerland. It predated specialized Catholic Action and the rival international Catholic student organization called Jeunesse Catholique Etudiant International (JECI) head-quartered in Paris. Rather than focus on intensive training and mobilization of militant student or working class youth, Pax Romana promoted international conferences and congresses for youth. The student wing of Pax Roman was called the International Movement of Catholic Students (MIEC in French). Pax Romana sponsored regional student conferences in Latin America in the interwar period in Mexico in 1931, and the first Inter-American Congress of Catholic students in Peru in 1931. "La Convención Ibero- 
In conclusion, before the Second World War the Italian Catholic Action, under pressure from the Italian fascist party, was forced to become less political and more authoritarian, thus pushing Italian Catholic Action to the right and out of the political sphere. On the other hand, the Franco-Belgian forms of specialized Catholic Action found themselves intensely competing with the socialist and communist parties, thus giving the specialized Catholic Action groups such as the JOC and the JUC incentives to occasionally move various degrees to the left in order to appeal to urban youth. ${ }^{98}$

After the war the movement experienced the explosive growth of transnational university movements in the postwar era and the transmission of both forms of Catholic Action from Europe to Brazil and Cuba. Key to this phenomenon was the influence of the two different types of Catholic Action upon the university student movements in each country with varying results. Both Brazil and Cuba faced the social problems of development, and both countries underwent some degree of revolutionary ferment. Cardijn's SCA methods, when applied in Brazil, eventually produced capable and independent young leaders who became very involved in social criticism and political action. The Italian model of Catholic Action which maintained a dominant influence in Cuba was inherently more corporatist in nature. The Cuban bishops attempted to restrain the incorpora-

\footnotetext{
Americano de Estudiantes Católicos Que Se Celebra en Mexico," Convocatoria, Confederación Nacional de Estudiantes Católicos de Mexico (Mexico City: Editorial CVLTVRA, 1931); and César Arróspide de la Flor, letter to Amoroso Lima, Director of Centro Dom Vital in Rio de Janeiro, Primer Congresso Americano de Estudiante Catolicos (Lima, Peru: Editorial CVLTVRA, 1932) in Bidegain Papers.

${ }^{98}$ Gerd-Rainer Horn considers Franco-Belgian specialized Catholic Action to have been a type of "Western European Liberation Theology." Horn, European Liberation Theology: 51; Curtis, "Modernity": 88.
} 
tion of specialized Catholic Action in Cuba in order to maintain the unity of the student movement and preserve the control of the hierarchy. 


\section{CHAPTER III}

TRANSNATIONAL STUDENT MOVEMENTS: 1946-1956

World War II interrupted the work of Catholic Action at the international level. In Europe, many members of the French and Belgian Catholic youth organizations joined the underground resistance to Germany. In Latin America, Catholic Action continued its work nation-by-nation as autonomous organizations under the control of the national hierarchies of each respective country.

Sociologists and historians of childhood generally agree that there was a unique emergence of youth culture in Western Civilization after World War II with the convergence of the lengthening of the period of youth (defined by dependence on parents) and the increasing affluence of youth and their new role as consumers in capitalist society. The word "teenager" first appeared in the postwar period that elaborated distinct teenage language, style, and music. Unlike the term 'adolescence', 'teenager' implied a distinct culture rather than a state of hormonal transition. Steven Mintz points out some of the significant cultural factors contributing to the emergence of youth culture: "nearly universal high school attendance ... early entrance into adulthood, and a high degree of affluence."1 Although Mintz focused on youth culture in the United States, the U.S. baby boom was the harbinger of a global phenomenon.

Since the post-war 'baby boom' of the 1950s and the student upheavals and the counter-cultural movement of the late 1960s, university students, their political views and

\footnotetext{
${ }^{1}$ Steven Mintz, Huck's Raft: A History of American Childhood (London and Cambridge: Harvard University Press, 2004), 285.
} 
their social roles became popular subjects of scholarly analysis. ${ }^{2}$ After the conclusion of the Second World War, several major international student movements came into existence, paralleling the emergence of a significant international youth culture. As Phillip Altbach noted in immediate aftermath of student activism of the 1960s, students became a factor which disrupted universities and provoked political crises and revolutions. The global student phenomenon became apparent more or less simultaneously in numerous developed and semi-developed countries indicating its transnational character. ${ }^{3}$ It appears that the rise of these international student organizations and attendant university upheavals were closely connected to the political and ideological conflicts of the Cold War. ${ }^{4}$

Immediately after the Second World War, efforts were made to create an international student organization, in part, to guard against the re-emergence of fascism. ${ }^{5}$ It was not long before the initial student organization fragmented into ideological polarized organizations. These competing international student movements became sites of ideological contestation in the early stages of the Cold War. ${ }^{6}$ The two most significant

${ }^{2}$ For example see Philip G. Altbach, Student Political Activism: An International Reference Handbook. New York: Greenwood Press, 1989; Student Politics in America: A Historical Analysis. New York: McGraw-Hill [1973, c1974], 1989; "Students and Politics.” In Students and Politics, edited by Seymour Martin Lipset. New York: Basic Books, 1967; Richard Cornell, Youth and Communism: An Historical Analysis of International Communist Youth Movements (1965); S. N. Eisenstadt, "Contemporary Student Rebellions: Intellectual Rebellion and Generational Conflict," Acta Sociologica 14, no. 3 (1971). Donald K. Emmerson, Students and Politics in Developing Nations (London: Pall Mall Press, 1968).

${ }^{3}$ Phillip G. Altbach “The International Student Movement.” Journal of Contemporary History 5 , no. 1 , Generations in Conflict (1970): 156.

${ }^{4}$ Philip G. Altbach and Norman T Uphoff, The Student Internationals (Metuchen, New Jersey: The Scarecrow Books, 1973), 4.

5 Ibid. 17.

${ }^{6}$ Altbach, "International Student Movement," 156. 
international student organizations were the International Union of Students (IUS), which was heavily influenced by the Marxist Eastern bloc, and the Western-oriented International Student Conference (ISC) which soon split off from the IUS. ${ }^{7}$

Conferences were held in London and Prague in 1945 to lay the groundwork for the formation of the International Union of Students (IUS). At the meeting in Prague, the International Union of Students was founded by representatives of student organizations from sixty-two countries. A driving motivation was the desire to avoid a resurgence of fascism in Europe. The IUS was initially composed of highly divergent groups, combining the communist student organizations from Eastern Europe with student unions from Western Europe. The Catholic student movements were anxious to participate and to attempt to bring to bear Catholic influence in the international student organization. ${ }^{8}$

The tendency of the Communist and leftist student groups to create a politicized movement was opposed by many of the western student organizations. By 1948 it was clear that the Cold War had become an integral part of the international student scene. The growing ideological tension between these two groups was a major factor in causing a split in the movement that occurred in 1950. After 1950, the IUS was largely left with student unions from the Soviet Union and its eastern European allies and a few from the developing areas. Twenty-one unions, mainly from Western Europe and North America, dissatisfied with the partisan attitude of the IUS, met in Stockholm in 1950 to plan a new movement. The new organization came to be called the International Student Conference (ISC). Both the IUS and the ISC were largely dependent on outside financial sponsorship.

\footnotetext{
${ }^{7}$ Ibid., 163.
} 
Almost all organizations, from the World Student Christian Federation to the Young Communist International of the 1920s, had been financially supported from sources outside their organizations. The cost of international meetings, large-scale publications, and the other activities were beyond the financial resources of university students. In the 1960s, there were innuendos that a portion of the ISC's budget originated with the CIA, although the ISC denied it. The growing international student movement was irretrievably polarized by the ideological divisions of the Cold War. ${ }^{9}$

\section{Transnational Catholic Student Movements Post-WWII}

The Catholic Church was not to be left behind in the effort to influence the emerging postwar generation of students. Catholic student movements already existed in many different countries of Latin America and Southern Europe as well as in many Francophone nations. In the new internationalism of the postwar Atlantic, efforts to initiate greater transnational coordination among the various national organizations quickly emerged. The Young Christian Workers movement (JOC), headquartered in Belgium, picked up where it left off before the war and continued developing its work among the Catholic working class youth internationally. ${ }^{10}$ The other branches of specialized Catholic Action, such as the Young Catholic Students (JEC) in France, Belgium and Quebec, followed the example of the Young Christian Workers in the See-

\footnotetext{
8 “Le Union Des Étudiants International," JECI International Bulletin (1948) 10, Bidegain Papers.

${ }^{9}$ Altbach, "International Student Movement," 167.

${ }^{10}$ Horn, European Liberation Theology, 51.
} 
Judge-Act method, flexible and semi-autonomous, lay leadership and apostolic mission focused on a distinct social class or milieu. ${ }^{11}$

As discussed in the previous chapter, Catholic student organizations were formed in the 1920s and 30s during the interwar period as part of a larger trend toward emerging youth organizations and youth mobilization by a variety of ideologies. The Catholic student organizations were commonly formed at the national level under the direction of the national and local diocesan bishops with very little transnational coordination. The names of these organizations varied from nation to nation. The student organization in Italy was the FUCI (Federation of Catholic University Youth). In France, Belgium and Quebec the student movement was known by the acronym JEC (Young Catholic Students).${ }^{12}$ In Brazil, there were two student organizations that worked side-by-side, the JUC (Catholic University Youth) and the university level and the JEC at the Secondary level. In Cuba, in addition to the JUC and the JEC, there was also the older and Jesuit led AUC (The Association of Catholic University students). ${ }^{13}$

The French JEC (young Catholic students) was modeled after the specialized Catholic Action of the young workers (JOC) movement in Belgium and represented a new paradigm for mobilizing university youth. The ideas of specialized Catholic Action initially spread among Francophone nations such as Canada, Belgium and France, but

${ }^{11}$ Coutrot, "Youth Movements," 27.

${ }^{12}$ Bulletin, "Rapport de la Commssion de Paris," in International Bulletin Des JEC et YCS (Paris: November, 1954), Bidegain Papers.

13 Report. "A la Opinon Publica, al Estudiantado en General," (Havana, 1949), Bidegain Papers; Jaime Suchlicki, University Students and Revolution in Cuba, 1920-1968 (Coral Gables, FL.: University of Miami Press, 1969). 
quickly took root in some countries of Latin America and Catholic countries of Africa and the Middle East. The initiative for organizational efforts was primarily at the local and national levels with occasional influence from traveling missionary priests or students who traveled to international conferences. Gradually many countries adopted the young Catholic "JEC/JUC" nomenclature (including Brazil and Cuba) which translated easily from French into Spanish and Portuguese. ${ }^{14}$

After the war, many leaders of various national chapters of the JEC felt the need to begin to coordinate their activities on a transnational level. The initiative for the formation of an international coordinating center came in 1948 through the members of the French-Canadian JEC, Gerard Pelletier in particular. Pelletier was a friend of Pierre Trudeaux, the future Premiere of Canada, and would himself eventually become the Canadian ambassador to the United Nations. Pelletier and his French Canadian 'jecista' colleagues are credited with being the prime movers behind the "Quiet Revolution" in Quebec in the postwar period. ${ }^{15}$

Parallel to the development of the secular international university organizations-the IUS and ISC--Catholic student leaders from Canada, the United States and France took the initiative to meet in the postwar period to organize a transnational coordinating

\footnotetext{
${ }^{14}$ In French speaking nations, "JEC" referred to both university and high school levels. In Latin America, "JEC" usually only referred to high school students; for university organizations "JUC" was the perferred name.

${ }^{15}$ The Quiet Revolution was a period of rapid social and cultural change in Quebec, Canada in the 1960s. French-Canadian society was transformed from traditional Catholic to a secular society with a welfare state. The provincial government took over health care and education which formerly were in the domain of the Catholic Church. It was also a period of economic and social development in Quebec. Many scholars attribute a key catalytic role to Catholic Action and the Catholic University Youth in fomenting the transition. See Gerard Pelletier, Years of Impatience: 1950-1960, Alan Brown (Toronto: Methuen \&
} 
agency for Catholic students. The first organizational meeting took place in November 1946 in Fribourg, Switzerland with the participation of representatives from nine countries in Europe and North America. ${ }^{16}$ Gerard Pelletier, the director of the Canadian JEC, played a key role as a founding member of the first JEC "International Session."17 The International bulletin published a series of discussions from the meetings in which the participants debated the meaning and significance of the JEC and its place within the overall scheme of Catholic Action. Even at this early stage, some of the text reflects leftleaning terminology that would later predominate in Brazil and prepare the ground work for liberation theology in Latin America. ${ }^{18}$

The Cold War was not yet in full swing in 1946, and there was still relatively greater tolerance in the West for the use of Marxist terminology in discussion of social problems. Nevertheless, it is still surprising to find a Catholic organization using terms such as "bourgeois" and "proletarian", and even "revolution" considering the Vatican's normal defensive hostility towards communism. The International Bulletin pointed out that the bourgeois class had greater access to material goods and culture. The report observed that material conditions were difficult and that the conditions were ripe for the emergence of a type of student proletariat. ${ }^{19}$ The second international gathering of the

Co., Ltd, 1984), and Michael Gauvreau, The Catholic Origins of Quebec's Quiet Revolution, 1931-1970 (Quebec: McGill-Queens University Press, 2005).

${ }^{16}$ Jean-Louis Janot to Pax Romana, July 10, 1956 (Miami: Florida International University, Department of Religion, Bidegain Papers).

${ }^{17}$ JEC Bulletin International (Paris: December, 1946), 1. Bidegain Papers.

${ }^{18}$ Ibid., 5; Bidegain, "Catholic Action to Liberation Theology," 18. 
JEC took place in September of 1947 just outside Paris, and for the first time included student representatives from Latin America and Asia. Nearly sixty student delegates gathered to share their common problems and to search for reciprocal solutions. They also set about developing a plan for an international coordinating commission for the various national chapters of the student and university movements. ${ }^{20}$

The JEC International coordinating committee began to work strategically to develop leaders in each country and to network them together through conferences and retreats. The Bulletin of May 1948 reviewed the progress made in Pointoise (Paris) and noted that the next World Session was scheduled to be held in August, 1948 in Chicago. The World Session was followed by a week-long retreat for relaxation and relationshipbuilding among the national directors and leaders for the national chapters of JEC. ${ }^{21}$ There was also substantive discussion of the future direction and political orientation of the secular IUS (International Union of Students) and its increasingly Marxist orientation. In the postwar context, Marxism was viewed as a competitive threat by the Catholic hierarchy and was considered to be the number one enemy of Catholicism. ${ }^{22}$ Also because of the Catholic goal of rechristianization and global expansion of Catholicism,

${ }^{19}$ Ibid.

${ }^{20}$ Pointoise, 1947, Jeunesse Estudiante Chrétienne: Seconde Session Internationale de la J.E.C. (Paris: 1947), 2-3, Bidegain Papers.

${ }^{21}$ JEC International Bulletin (Paris: December, 1948): 1, Bidegain Papers; JEC International Bulletin (Paris: July-August, 1956): 2, Bidegain Papers.

${ }^{22}$ Louise Bienvenue, Quand la Jeunesse Entre en Scene: L'Action Catholique Avant la Revolution Tranquille (Montreal: Les Editions du Boreal, 2003), 116; Kenneth P. Serbin, "Church-State Reciprocity in Contemporary Brazil: The Convening of the International Eucharistic Congress of 1955 in Rio de Janeiro," The Hispanic American Historical Review 76.4 (Nov 1996): 735; Michael Löwey, The War of Gods: Religion and Politics in Latin America (London, UK: Verso, 1996) 66. 
the bishops desired to bring Catholic influence to bear on the secular international student organization. The bulletin observed that the student delegates from Denmark, Sweden, France and Great Britain had attended the most recent meeting of the IUS with instructions from their national unions to condemn the actions of the Secretary of the IUS. The author of the article raised two questions to be considered by the Young Catholic Students leaders: 1) would the IUS continue in its current political direction? 2) What kind of political presence could be sustained within the IUS in light of its intensifying orientation? ${ }^{23}$ By 1949, the International Bulletin left no doubt that the Cold War was underway in full force. One of the main articles alluded to the Iron Curtain. ${ }^{24}$ In the face of the communist threat, Catholics were working to build up a defensive transnational bulwark of Catholic youth.

\section{International Coordination}

As the number and variety of Catholic student and university movements, as well as the multitude of other lay-led Catholic Action groups, multiplied throughout Europe and the Americas it became apparent that there was a need for greater international coordination. The need was especially acute in order to effectively represent a Catholic perspective to the secular transnational student unions such as IUS and ISM and the various agencies of the United Nations such as UNESCO (United Nations Educational, Scientific and Cultural Organization). ${ }^{25}$

\footnotetext{
${ }^{23}$ Ibid., 11.

${ }^{24}$ JEC International Bulletin (Paris: March 1949): 3, Bidegain Papers.

${ }^{25}$ JEC International Bulletin (Paris: December, 1948): 10, Bidegain Papers.
} 
The JEC functioned along the lines of specialized Catholic Action and the international leaders tended to be from the Anglo-French countries of Western Europe that fought against the Nazi's and Fascists in The Second World War. The other major international coordinating agency for Catholic student movements was Pax Romana, already mentioned above. Pax Romana focused on organizing large international congresses and worked primarily with students and intellectuals along the lines of general Catholic Action. A large number of the leaders of Pax Romana were German or Spanish in origin and thus had a different set of sympathies regarding the type of corporatist regimes that were in power in Spain and Portugal, for example. The overriding concern of Pax Romana was how to respond to the international threat of communism. The Franco-Belgian JEC's overriding priority it these same years was how to bring the Catholic faith to bear on the pressing social and economic problems of developing countries, particularly in Latin America. These divergent priorities would cause the two international centers of Catholic student activity to find themselves in tension with one another in Latin America during the course of the $1950 \mathrm{~s}^{26}$

By the mid-1950s, the International Commission of the JEC located in Paris became more intentional in its efforts to coordinate student movements in multiple nations. In 1954, the Centre International pour la Information et Documentation (CIDI) officially adopted a new name, Jeunesse Étudiant Catholique Internationale (JECI). ${ }^{27}$ The head-

\footnotetext{
${ }^{26}$ Ana Maria Bidegain, "Influencia De La Guerra Fría En El Movimiento De Universitarios De Acción Católica," unpublished paper (Bogota: Universidad Nacional de Colombia), 10.

${ }^{27}$ JECI stands for Young Catholic Students International in English. CIDI, translated in English, was International Center for Documentation and Information. The original name reflects the somewhat decentralized and "federated" nature of the specialized Catholic Action youth movements.
} 
quarters were located in Paris and represented the Franco-Belgian and Canadian specialized Catholic Action directed toward university students. ${ }^{28}$ The Catholic Student Youth International had adopted many of the features of Cardijn's Young Christian Workers (JOC) and focused on forming highly committed Catholic 'militants' through the SeeJudge-Act, revision of life, method.

The Catholic Student Youth International (JECI) was also working on developing internal regulations and infrastructure for the international student movement. New articles and statutes were discussed and approved to form the governing basis for the organization. The various national movements of JEC (male and female) voted to empower the JECI to develop a coordinating plan to hold the national chapters accountable in their social and theological orientations; to develop new openings in countries where JEC did not yet exist; and to coordinate their actions at the transnational level. The January 1954 edition of the JECI bulletin discussed plans for upcoming meetings with the leaders of German, French, Belgian and British student organizations. ${ }^{29}$

Nevertheless, JECI was primarily an umbrella organization; it was not intended to represent a superior hierarchical authority over the national organizations. The internal regulations that were agreed upon upheld the autonomy of each national movement. The national secretaries accepted the need of the JECI Commission to encourage common positions about the international problems of youth. These common positions could only

\footnotetext{
${ }^{28}$ Souza, A JUC: 87.

${ }^{29}$ JEC International Bulletin (Paris: January 8, 1954): 2, Bidegain Papers.
} 
be taken with the unanimous support of all the voting member organizations. ${ }^{30}$ The signatories of the foundational internal regulations for JECI included male and female members from the national student groups of the JEC/JUC from Brazil, Belgium, Canada, England, France, U.S., Lebanon, and Switzerland. ${ }^{31}$

The Catholic student movement offered an early acknowledgement of the value of women's participation in leadership by including a young French-Canadian woman in the JECI leadership team for the year 1953-1954, along with three young men from Brazil, France and Lebanon. ${ }^{32}$ Of the twenty-four students representing seven countries, one third of the participants were women. The inclusion of students from Brazil and Lebanon on the international executive committee also indicated a commitment to decentering the organization and including students from the developing world in leadership. At the beginning, the Catholic university movements made extraordinary efforts to make room for female leadership at the national and international levels, and to decentralize its international leadership by including and promoting students leaders from developing nations. ${ }^{33}$

The April Bulletin contained an article defining and discussing the roles of "militants" in the female wing of the student movement. Female militants were expected to gain more awareness of their responsibility with regard to their sphere of influence and to

${ }^{30}$ Ibid.: 4.

${ }^{31}$ Ibid.: 5 .

${ }^{32}$ The four students were Marie-Paule Saint Marie of Canada, Celio Garcia from Brazil, JeanLouis Monzat of France and Marcel Abaoussouan of Lebanon. JEC International Bulletin (Paris: April, 1954): 5, Bidegain Papers.

${ }^{33}$ JEC International Bulletin (Paris: January 8, 1954): 10, Bidegain Papers. 
effectively engage others in order to promote Christianity. Such militants ideally should have some degree of influence within the student "milieu" because of their involvement in student organizations at the leadership level. ${ }^{34}$ The author observed that the female militant should progressively discover the truth of the gospel and must learn to develop with the life of Christ within a team dynamic. The militant was also to be a person of initiative and practical action. Such action necessarily must always be carried out through team work and the militant was never to act alone. ${ }^{35}$

The role of the clerical chaplain or "assistant" (normally a priest) was to encourage the spiritual life of the team, and help each militant grow deeper in her knowledge of doctrine and to be a spiritual support to each. Although the chaplains were normally ordained priests, the national JEC (or JUC) organizations were very careful to guard their own autonomy and to define a role in which the priest functioned as an advisor but not a director. The International Bulletin of April, 1954 defined the role of the advisor as one who would give advice and spiritual encouragement but would respect the "apostolic responsibility of the militants" (student leaders). ${ }^{36}$ The relative autonomy from clerical supervision was a significant difference which distinguished the specialized Catholic Action from the Roman model which developed under pressure from the Italian fascists in

\footnotetext{
34 "Milieu" was a frequently used word in specialized Catholic Action for which it is difficult to give an exact translation in English. Basically it means the person's social and relational environment or network, including social class and profession. For a student, that would mean their university environment and perhaps their particular area of study. For a young worker, it would include their workplace and neighborhood friends and family. French).

${ }^{35}$ JEC International Bulletin (Paris: April, 1954): 4, Bidegain Papers (author's translation from 30.

${ }^{36}$ JEC International Bulletin (Paris: April, 1954): 5, Bidegain Papers; Coutrot, Youth Movements:
} 
the 1930s in which the student leaders were under the direct supervision of priests and exercised considerably less autonomy. ${ }^{37}$

The JEC/JUC student organizations perpetuated a training strategy that had been created in the 1920s by Fr. Cardijn, the Belgian founder of the Young Christian Workers (JOC) organization which pioneered the initial development of specialized Catholic Action. The International Bulletin in May 1948 emphasized the importance of action. According the article, action was the key element that made students aware of the movement of history. The author believed that not only economic, social or political action was important, but also spiritual movement in history. ${ }^{38}$ The process of the revision of life (also called the See-Judge-Act method) was born within this integral movement and represented much more than a simple method; it was an integrated way of life. The revision of life was also an essential pedagogical tool for the JEC: a daily discipline for the formation of student militants radically committed to social transformation. This was a "reflective engagement of a team of militants." 39

The discourse of JEC not only emphasized concrete action as a form of spirituality, but also the necessity of community. In addition, there was a strong discursive resistance to western individualism. The general trend in the emerging 'babyboom' in the West was rampant individualism. The student leaders of the JEC movement sought to be a counter-cultural influence in true Catholic fashion. The importance of

\footnotetext{
${ }^{37}$ Rhodes, The Age of Dictators, 51.

${ }^{38}$ JEC International Bulletin (Paris: May, 1948): 5, Bidegain Papers.

39 "Fundamental Orientations and Organization of JEC International," in World Council Report (Broummana: 1964): 350-351, Bidegain Papers.
} 
belonging to a spiritual community was clear, "We find our salvation together - one does not save oneself alone. Humanity is seeking community." ${ }^{40}$ According to the authors of the article, living in community should not imply inward-focused passivity, but rather acting in a transformative community. Establishing a true spiritual community depended less upon words than acts. One must struggle against one's own spiritual individualism, from which springs other forms of individualism, and in particular those that deform charity. $^{41}$

In the December 1948 Bulletin, one finds surprisingly radical language. Perhaps the Cold War had not yet fully cast a chill upon progressive political views. In an article titled "The purpose of JEC," there was a discussion of the need to participate in a "social revolution" and to "liberate" the church and to present to students a type of Christianity fully committed to human liberation. The specific challenge was for the church to mobilize students to pursue transformative action in the world. The language of "liberation" that would later animate liberation theology was already circulating in Catholic student circles in $1948^{42}$

The editors of the JECI bulletin in Paris were intensely interested in developments within the world-wide secular university organization. The bulletin included a report on the political orientation of the International Union of Students (IUS) which had not yet split into competing Western-democratic and Eastern-bloc Marxist organizations. The author observed that the IUS appeared to be stronger than ever despite internal conflict

\footnotetext{
40 "Seeking a Spiritual Community," JEC International Bulletin (Paris: May 1948): 5, Bidegain Papers ${ }^{41}$ Ibid.
} 
over student demonstrations and the imprisonment of students from Czechoslovakia by Marxist authorities. The analysis asked: Would the IUS continue in its drift to the left? And, if yes, how would that affect the unity of its members? A related question for the JEC was what kind of Catholic presence could be sustained within the IUS as it became increasingly aligned with the communist Eastern bloc? ${ }^{43}$ The author affirmed the role of the IUS in denouncing European colonialism, but pointed out the hypocrisy in not equally criticizing the communist coup of February 1948 in Czechoslovakia. ${ }^{44}$ The January 1954 edition of the JEC bulletin discussed plans for upcoming meetings with the leaders of German, French, Belgian and British student organizations. ${ }^{45}$ The leaders of the international Catholic university movement were clearly interested in exerting as much influence as possible in the future direction of the IUS. ${ }^{46}$

In addition to the JEC International (JECI), there was another transnational Catholic organization focused on working with universities and students as mentioned above. The older student organization was called Pax Romana, as an allusion to the international peace that reigned during the Roman Empire. Pax Romans did not utilize the See-Judge-Act method of training militants and was not primarily concerned with character formation on a personal or one-to-one basis but focused on gathering students and intellectuals together in large congresses or international and regional conferences.

${ }^{42}$ JEC International Bulletin (Paris: December 1948): 1, Bidegain Papers.

${ }^{43}$ Bob Rambusch, "L’Union Internationale Des Étudiants," JEC International Bulletin, (Paris: December 1948): 10, Bidegain Papers (author's translation from French).

${ }^{44}$ Rambusch, "L’Union Internationale,” December 1948: 12.

45 JEC International Bulletin (Paris: January 8, 1954): 2, Bidgain Papers. 
The student wing of Pax Roman was called the International Movement of Catholic Students (MIEC in French). ${ }^{47}$

At the conclusion of the Second World War, the student wing of Pax Romana reinitiated its activity in Latin America in Lima Peru, with the II Inter-American Assembly of Catholic University Students in March of 1946. Themes that were discussed at the Inter-American Assembly included the responsibility of Catholic students for the university, the need for university reform and the task of re-Christianizing the university. ${ }^{48} \mathrm{~A}$ list of the names of the various national and international agencies and their delegates appeared in the Assembly report (Documentos). Among the national delegations participating in the Inter-American assembly were Argentina, Bolivia, Canada, Colombia, Chile, Ecuador, France, Guatemala, Mexico, Paraguay, Peru, Spain, Uruguay, the United States. $^{49}$

During the mid-1950s, Pax Romana helped organize eight regional conferences in Latin America, including three in the Southern Cone region, three in the Mexico-Central America and Caribbean area, and two in the Andean region. The largest gathering was the previously mentioned conference in Havana which brought together 93 student lead-

${ }^{46}$ Rambusch, JEC International Bulletin, (Paris: December 1948): 10, Bidegain Papers ; Memorandum. Folder Juventud Femenina y Masculina, Catholic Action (Havana: 1950): Arcebispado.

${ }^{47}$ Pax Romana was an international organization of Catholic intellectuals and students that was started between the World Wars in the hope of promoting peace. Its headquarters was located in Fribourg, Switzerland. It preceded the International JEC organization located in Paris and was more connected to the corporatist Roman or Italian model of general Catholic Action than to the Franco-Belgian specialized model.

48 “Documentos," II Asamblea Interamericana de Universitarios Católicos, (Lima, Peru: 1946): 27-32, Bidegain Papers.

49 “Documentos” (1946): 55-65. 
ers and advisors from the Mexico-Caribbean region. Regional meetings in December of 1956 in San Salvador were also well attended. The InterAmerican Bulletin reported that from 1953 through 1956, Pax Romana had been actively involved in twenty countries with thirty-four Federations involving 378 student leaders. Future regional meetings were planned for 1958 in Buenos Aires, Quito and Panama. ${ }^{50}$

As stated above, Pax Romana operated on an entirely different paradigm than the specialized Catholic Action student movements, JEC and JUC. Whereas the specialized student and university movements focused on intensive personal formation through the See-Judge-Act method developed by Cardijn, Pax Romana emphasized bringing together large numbers of students for multi-national gatherings at conferences, congresses and study retreats. Although Pax Romana was an intellectual movement, it was not designed to recruit, train and mobilize militant evangelists from distinct social milieu. Nevertheless, Pax Romana had a looming and influencial presence in Southern Europe and Latin America. The Italian model of Catholic Action was accustomed to working congenially with Pax Romana, but the newer specialized Catholic student movements, represented in Paris by the JEC International (JECI) would eventually find areas of uneasy overlap and competition with Pax Romana. 51

National Catholic Student Movements: Cuba and Brazil

At the same time that secular and Catholic transnational university movements were emerging in Europe after the end of the Second World War, there was a postwar

50 "Reuniones Nacionales," Boletín Interamericano de Información (Havana, Cuba: Editorial Echevarria, 1957): 2, Bidegain Papers. 
resurgence of Catholic university movements in numerous countries of the Atlantic world. In general, the rapid growth of university student populations in the developing world was caused by urbanization and the accelerated modernization that required increasing levels of higher education to produce modern middle-class professionals. Although the student population in all of Latin America was only a percentage of the university population in the United States, university students in Latin America exercised a level of social influence as intellectuals and future professionals much greater than their counterparts at U.S. universities. ${ }^{52}$ The majority of Latin American countries, as well as many of the Spanish speaking islands of the Caribbean and French Canada, had a predominantly Catholic heritage. Also, many African nations that had come under the colonial control of Portugal, Belgium or France also had significant numbers of Catholics. Of the many potential examples, two national case studies are useful to examine the development and transnational connections of the Catholic Student movements: Brazil and Cuba.

\section{Catholic Student Movements in Cuba: 1946-1956}

Catholic efforts to reach Cuban youth began through the efforts of a French priest who emigrated to Cuba via Montreal. Hermano Victorino founded the Catholic youth outreach in Cuba, the Juventud Católica Cubana, in 1928. He was born in rural France on September 7, 1885. Victorino entered into the orders with the Hermanos de la Salle in 1901, and departed France for Canada in 1904, along with seventy other members of the

51 Jean-Louis Janot to Pax Romana, "En Response au Memorandum de Pax Romana-MIEC,” July 12, 1956. Bidegain Papers. 
brotherhood. In 1905 at 20 years of age, Victorino volunteered to leave Quebec to go to Cuba to found schools in the company of fourteen other brothers. ${ }^{53}$

In February of 1928, after serving over twenty years in Cuba and at forty years of age, Victorino launched the Juventud Católica Cubana with a constitution signed by student delegates from fourteen Catholic High Schools in Havana and with the approval of the Archbishop of Havana, Manuel Rúiz, and Manuel Arteaga Betancourt, then VicarGeneral of the archdiocese.$^{54}$ Victorino's efforts to reach young people were tireless. The first annual celebration of the Dia de la Juventud Católica (Day of the Catholic Youth) was held in the Cathedral of Havana on the last Sunday of September in 1936 with 1,500 young people attending. Victorino also became involved in launching "grupos" for young Catholics in other parts of Cuba in the early 1930s. ${ }^{55}$

By 1938, the Cuban bishops were calling for the formal unification of all the Catholic lay movements, both youth and adult, within one international umbrella organization, known as Catholic Action. Cuban Catholic Action was officially established in 1940, coinciding with the creation of the Cuban political constitution of 1940. Victorino's Juventud Católica Cubana (JCC) was the most dynamic and expansive group within the national Cuban Catholic Action. The JCC grew rapidly during the war years. In 1939, representatives from 75 groups from around the entire island participated in a national conference held in the central region of Cuba in the village of Placetas. By 1941, the

\footnotetext{
${ }^{52}$ Altbach, "Student Politics," 650.

${ }^{53}$ J Diaz, comp., Victorino: Hermano de la Salle: Fundador de la Juventud Católica (Hermanos de la Salle) 6.

${ }^{54}$ J. Diaz, Victorino, 12.
} 
number of youth groups had doubled; many attended national conference held in Cárdenas with the participation of 150 groups. By 1943, there were over 300 groups with 7,000 young men and women participating. By this time the Cuban hierarchy had acknowledged the significance of the Catholic youth movement by officially constituting two separate youth branches of Catholic Action: The Juventud Católica Cubana Feminina (young Cuban Catholic women) and the Juventud Católica Cubana Masculina (young Cuban Catholic men), each with their own constitution and officers. ${ }^{56}$

In the postwar period, a new generation of church leaders was promoted into a place of national influence in the Cuban Catholic Church. In December of 1945, Manuel Arteaga was appointed to be the first Catholic cardinal of Cuba by Pope Pius XII. ${ }^{57}$ Monseñor Arteaga would eventually play a key role in the 1950 s in the attempt to maintain the delicate balance between the government and the political turmoil in Cuban civil society. In 1948, Enrique Pérez Serantes, of Spanish origin, was appointed to be the Archbishop of Santiago de Cuba. Pérez Serantes was also destined to play a key role in the future of Cuban Catholicism. ${ }^{58}$

\footnotetext{
${ }^{55}$ Ibid.

${ }^{56}$ The Spanish Juventud Católica Cubana Feminina can be translated "young Cuban Catholic women" and Juventud Católica Cubana Masculina, "young Cuban Catholic men." Catholic Action youth movements in most countries were normally divided into seperate branches on the basis of gender. This often inadvertantly provided greater space for female autonomy and leadership. Although the focus was on youth, it was not yet specifically focused on university students. This type of organizational structure represented the more traditional and conservative Italian model of Catholic Action which was normally divided into four branches (adult men and women and male and female youth) and focused on piety and liturgical participation at the parish or diocesan level.

${ }^{57}$ Fernández Soneira, Estrella y la Cruz, 38-39, 221; Falcon, Social Role, 72; Revista Bohemia, December 30, 1945, 35.
} 
By the end of the 1940s, the Catholic youth movement began to achieve greater visibility in Cuban society. Victorino's Catholic students (male and female) began an annual practice of celebrating the Day of Catholic Action Youth with a meeting in the Central Park of Havana and with youth speakers addressing moral issues in Cuba and points of Catholic doctrine. ${ }^{59}$ In February, the Inter-American Week of Catholic Action was celebrated in Havana. A group of student leaders of the JCC (Catholic Action Youth) initiated a "Humanist Movement" inspired in part, by the ideas put forth by Jacques Maritain in his book "Integral Humanism," and in part, by the Social Democratic Party of Chile. ${ }^{60}$ Catholic student leaders were beginning to see an enlarged role of leadership in Cuban society.

From 1928 through the war years, the mobilization of Catholic Action youth spearheaded by Hermano Victorino strictly operated along the lines of general Catholic Action following the Italian model of Pope Pius XI. Although Victorino himself was French, he had departed from France in 1904, long before specialized Catholic Action existed and at a time when the French Catholic Church was quite conservative and on the defensive against the twin 'heresies' of modernism and anti-clericalism. When specialized Catholic Action began to emerge in the 1930s in France, Victorino was already in Cuba and hard at work developing an outreach to youth following the older, more tradi-

${ }^{58}$ The Hierarchy of the Catholic Church, Current and historical information about its bishops and dioceses: http://www.catholic-hierarchy.org/; Yolanda Portuondo, Guillermo Sardiñas, Sacerdote Commandante - Testimonio (La Habana, Cuba: Editorial Cultura Popular, 1988), 51.

59 “El Dia de la Juventud Católica: Aconsejan la Práctica de una Democracia Cristiana,” Diario de la Marina (no date): Acebispado.

${ }^{60}$ Manuel Fernández Santalices, Cuba: Catolicismo y Sociedad en un Siglo de Independencia (Caracas: Honrad Adenauer Stiftung, 1996), 49. 
tional parish-focused form of Catholic Action. It was not until after the Second World War that the innovative form of specialized Catholic Action began to filter into Cuba through the agency of Joseph Cardijn's young Christian worker movement (JOC). ${ }^{61}$

The Juventud Obrera Católica (JOC) or Young Catholic Worker's movement became active in Cuba in the postwar period. ${ }^{62}$ In January of 1947, the JOC, the specialized branch of Catholic Action that focused exclusively on working class youth, was officially established in Cuba by Cardinal Manuel Arteaga. In February 1952, the first Regional Congress of JOC for the Caribbean and Central America was celebrated in Havana with Father Joseph Cardjin as the keynote speaker. His visit nearly coincided with the seizure of power by Fulgencio Batista a few weeks later. Batista was promptly congratulated by Cardinal Arteaga and who offered his respects to the new dictator. ${ }^{63}$ Despite the cordial support given to the Batista government by the upper echelons of the Catholic hierarchy, the young working class militants of the JOC opposed the illegality and corruption of the Batista regime. ${ }^{64}$

In 1950, a Catholic University center, the Hogar Católico Universitaria (Cathoilc University Home), opened in Havana under the initiative and direction of Hermano Vic-

${ }^{61}$ Juventud Obrera, March 1948; Blanca Hernandez, “A Las Presidentas Diocesanas,” Circular Num. 10, (1948): Arcebispado.

${ }^{62}$ Notice the change of name from Cardijn's ecumenical "Chrétien" to the more conservative name in Spanish: Juventud Obrera Católica. See Luiz Alberto Gómez de Souza, Do Vaticano II a um novo concílio?: o olhar de um cristão leigo sobre a Igreja (São Paulo, Brazil: Edições Loyola, 2004), 63; Mainwaring, Church and Politics, 118; Paiva, Católico, Protestante, Cidadão, 168-169.

63،"Envía Su Eminencia, el Cardinal Arteaga un mensaje al Gra. Batista," Diario de la Marina, March 20, 1952; Fernández Soneira, Estrella y la Cruz, 303; Fernández Santalices, Cuba, 51.

${ }^{64}$ Inacio Bain, ed., "La JOC y la Unidad,” La Quincena (Havana: May 17, 1959): 27, Cuban Heritage Collection. 
torino. On May 15 1950, Cardinal Arteaga wrote a letter suggesting that collections be taken up in the local parishes to help support. ${ }^{65}$ In the letter, he quoted the Holy Father as saying that the university students merited the special attention of Catholic Action because these young people would make up the future leaders of the nation. He also pointed out that many of the students from rural provinces were not prepared to live in Havana and to deal with the urban culture. They therefore, needed a place to reside where there was a Christian environment such as the Hogar Católico. In order to develop and maintain the Hogar and to help develop the Catholic university movement, Arteaga authorized that half of the collection in the churches in Havana and in Marianao on the first Sunday of October be directed toward that purpose. ${ }^{66}$

Hermano Victorino spoke to the National Assembly of the Federation of Catholic Action Youth in February of 1953. The occasion marked the twenty-fifth anniversary of the founding of Juventud Católica Cubana in 1928. He compared the growth of the Cuban Catholic youth to a small seed in 1928 which has grown into a large and fruitful tree by 1953 . After discussing the rapid growth of the work of the Catholic Action youth in Cuba from 1935 through the postwar period, Hermano Victorino raised the issue of the new form of specialized Catholic Action and urged caution. "One must admit that specialization had many advantages but in our case, it must be implemented with caution. We should not, and cannot imitate other countries in this respect, because our conditions

\footnotetext{
${ }^{65}$ Manuel Arteaga, "Hogar Católico Universitaria,” (Havana: May 15, 1950), Arcebispado.

${ }^{66}$ Arteaga, “Hogar Católico,” May 15, 1950.
} 
and circumstances are very different. ${ }^{967} \mathrm{He}$ continued the discussion about the problems of specialized Catholic Action by pointing out the transitory nature of student and university ministry. In Victorino's view, it was important that the university leaders be formed to think beyond their university experience so that as professional and future leaders of Catholic Action, they could continue their apostolic involvement as adults. Victorino was concerned that by transforming the JCC youth movement from a general parochial entity into diverse specialized movements organized around social class and profession, their ongoing participation in Catholic Action and in the life of the church would be undermined. He qualified the experience of Cardijn's worker's movement by noting that, although the JOC was a specialized movement and was born outside of Catholic Action, it was very stable and "fijo" (fixed), implying that a specialized student or university movement would be potentially destabilizing for the Catholic youth movement. ${ }^{68}$

In Victorino's view, the key structure of the growth of the Cuban Catholic youth from before the Second World War was the parochial and diocesan small groups (which he himself was largely responsible for creating). These groups were the most likely to suffer from the development of specialized sections as students and young workers refocused their attention on their respective academic and social milieu. He also warned that the specialized movements tended toward a certain degree of autonomy in the expansion

\footnotetext{
${ }^{67}$ Hermano Victorino, "Message to the National Assembly of the Federation of Catholic Action Youth," (Havana: Febuary 1953) 2: Arcebispado.

${ }^{68}$ Ibid.
} 
of their action. Victorino urged that specialization should be implemented cautiously and selectively for the greater good. ${ }^{69}$

Victorino's expression of caution about adopting innovative approaches to Catholic youth ministry coincided with increasing political instability in Cuban society and stagnation in the Cuban economy. As mentioned previously Batista carried out a military coup in March of 1952, when he found himself losing in a three-way race for President. Despite Batista's assumption of power and the suspension of the 1940 constitution, he was quickly extended recognition by the United States government and received warm congratulations from the Catholic hierarchy. Victornino's expressions of caution in the midst of a turbulent social situation may have reflected a larger caution on the part of the church to address the social and political instability of the nation. ${ }^{70}$ Despite the initial caution of Hermano Victorino and the Cuban ecclesiastical hierarchy regarding the danger of specialized Catholic Action, some elements of the Franco-Belgian form of Catholic youth movements began to be incorporated into the Cuban youth movement in a modified form in the $1950 \mathrm{~s}^{71}$

Despite the Catholic hierarchy's attempt to maintain cordial relations with Batista, tensions began to grow between the Church and the Batista Regime as he tightened his grip on power. Revista Bohemia describes in detail the disruption of a gathering of the Juventud de Acción Católica Cubana (JAC) on May 20 1953, in Guanajay when the

\footnotetext{
${ }^{69}$ Victorino, “Message,” Febuary 1953, 3.

${ }^{70}$ Joseph W. Holbrook, "The Church in Cuba, 1952 - 1959: Ambivalence Between Regime And Revolution," (Miami: Florida International University, 2007) 20.

${ }^{71}$ Victorino, “Message,” Febuary 1953, 3.
} 
meeting was interrupted by Batista's police. ${ }^{72}$ Just two short months after the Guanajay incident, political tensions in Cuba rose again with Fidel Castro's attack on the Moncada army barracks. Fidel and a handful of men survived the attack and fled into hiding. Monseñor Eduardo Pérez Serantes, archbishop of Santiago, sought out Castro and persuaded him to surrender, thus possibly saving his life. ${ }^{73}$

In response to the continuing anti-democratic oppression and corruption of the Batista government, a group of Young Catholic Action (JAC) leaders formed the MLR, the Movement of Radical Liberation (Movimiento de Liberación Radical) with the intent of opposing the authoritarian regime. Catholic student leader, José Antonio Echevarría, was elected as President of the Federación Estudiantil Universitaria (FEU, Student University Federation) in 1954, the same year as Fulgencio Bastista was elected as President in what was likely a rigged election. ${ }^{74}$ Castro went into exile in Mexico in April of 1955. ${ }^{75}$ Several revolutionary groups were formed including the MLR mentioned earlier and the Revolutionary Directory, composed largely of students, was formed with the goal of armed insurrection against Batista. ${ }^{76}$

\footnotetext{
${ }^{72}$ Revista Bohemia, May 1953 (Miami: Florida International University: Government Documents); Fernández Soneira, Estrella y la Cruz, 373.

${ }^{73}$ Manuel Fernández Santalices, Cuba: Catolicismo y Sociedad en un Siglo de Independencia (Caracas, Venezuela: ODCA, 1996), 51.

${ }^{74}$ Fernández Santalices, Cuba, 54.

75 “Grave Crisis Nacional,” Revista Bohemia, (Havana: November 27, 1956): 73; Editorial, “Alto el Fuego!" Revista Bohemia, December 15, 1956, 53; “Que cese esa violencia suicidia!!” Revista Bohemia, December 30, 1956, 51.

76 “Une Manifesto de la F.E.U. al Pueblo Cubano” Revista Bohemia, November 27, 1956, 78.
} 
The Catholic student movement in Brazil arose within the context of Catholic Action in the late 1920s and early 1930s. Christine de Hemptine of Belgium, the international head of Women's Catholic Action since 1926, traveled to Rio de Janeiro in 1932 on her way to Buenos Aires and Montevideo to encourage the development of Catholic Action with the blessing of Pope Pius XI. ${ }^{77}$ She returned again in 1934 and served as an important catalyst to launch Brazilian Catholic Action in the same year and the Catholic university movement (JUC) began soon after in $1937 .^{78}$ The early form of the Catholic university student movement was initially cast in the mold of the Italian model of general Catholic Action with its focus on the parishes and diocesan structure and the organization into four branches of lay people by gender and age: adult women and men, young women and young men. ${ }^{79}$ The university outreach was organized as a subunit of the Catholic Action youth branch. ${ }^{80}$

Catholic students began to organize, readying themselves to participate in student politics at both the local and national levels within a context of increasingly vocal and active university student involvement in transnational and geo-political issues. Although

${ }^{77}$ Ana María Bidegain, Participación y Protagonismo de las Mujeres en la Historia del Catolicismo Latinoamericano (Ciudad Autonoma de Buenos Aires: San Benito, 2009), 44.

${ }^{78}$ Padim, interview, May 28, 1990; Bidgain, Participación y Protagonismo: 45.

${ }^{79}$ The Specialized Franco-Belgian model of Catholic Action, which became more predominant after WWII, divided 'militants' by class of origin and profession, and occasionally by gender into the following groups: JIC (Young Independent Catholics), JEC (Young Catholic Students), JOC (Young Catholic Workers), JAC (Young Catholic Agriculturalists), and JUC (Young Catholic University students) and was less controlled by the bishops and more of a sodality in its organizational model.

${ }^{80}$ Padim, interview, May 28, 1990 (Juventude Accão Católica masculine: Translated by author from Portuguese). 
there was some student activism against the dictatorship of Getúlio Vargas, the Catholic student movement focused primarily on liturgical and devotional piety during the interwar years (1930s). ${ }^{81}$ Nevertheless, the Brazilian Church was able to gain significant strength during the populist rule of Vargas as it was able to deliver critical support from the masses of Catholic faithful. During these years (1930s), the first contacts were made with the Young Christian Workers form of specialized Catholic Action in Belgium through young Brazilian women such as Betty Ramos who traveled to Belgium for study and education. ${ }^{82}$

The Catholic hierarchy sought to compensate for its gradual loss of political and social influence by taking advantage of student involvement in society, especially after the Second World War. In the 1940s, the Catholic Church was threatened by the same crisis that was creating strains in Brazilian society: the transition to an industrial order, urbanization and the rapid proliferation of higher education and the formation of modern political parties. ${ }^{83}$ These economic and developmental changes emerged unevenly, creating wide-spread social instability. The Catholic students were encouraged by the bishops to attempt to engage these social issues within Academic spheres from a Catholic perspectective. $^{84}$

${ }^{81}$ Padim, interview: May 28, 1990; Frei Carlos Josaphat, interview, March 12, 1997.

${ }^{82}$ Bidegain, Participación y Protagonismo: 47.

${ }^{83}$ Ralph Della Cava, "Catholicism and Society in Twentieth-Century Brazil," Latin American Research Review, Vol. 11, No. 211.2 (1976): 18.

${ }^{84}$ W. E. Hewitt, Base Christian Communities and Social Change in Brazil (Lincoln, Nebraska: University of Nebraska Press, 1991), 17. 
The postwar social and economic problems in Brazil included crushing poverty, illiteracy and chronic unemployment in the Brazilian northeast, massive internal migration caused by rapid urban growth in Rio de Janeiro and São Paulo. As poor and rural Brazilians migrated to the large urban centers, illegal shantytowns called favelas--lacking basic services such as water, sewage and electricity--multiplied on the hillsides surrounding middle- and upper-class neighborhoods. Brazil faced similar problems of social inequity, economic dependence and chronic technical and industrial underdevelopment that challenged the other countries of Latin America in the second half of the twentieth century. Economic opportunity could not keep pace with massive population growth. ${ }^{85}$

As Catholic students sought to become more involved in their academic departments in order to project Catholic influence, they were forced to engage with these social problems and to understand the use of modern economic and social theories and methods to address such problems. The student movement was encouraged by their chaplains and clerical advisors to integrate their Catholic values into comprehensive solutions for the pressing social and economic problems of Brazil. ${ }^{86}$

Some of the key individuals who helped to guide the development of the JUC in the postwar period were themselves students in the late 1930s. The future Archbishop, Dom Cândido Padim, became a student militant of the Catholic student movement in 1937 while studying law. In a later interview, he recalled joining with other students to

\footnotetext{
${ }^{85}$ Fernando Henrique Cardoso and Enzo Faletto, Dependency and Development in Latin America, Marjory Mattingly Urquidi (Berkeley: U of California P, 1979) 27; Rosemary Thorpe, Progress, Poverty and Exclusion : An Economic History of Latin America in the 20th Century (Washington: Johns Hopkins UP, 1998) 275.
} 
oppose the dictatorship of Getúlio Vargas. It was during his involvement as a student militant that Padim embraced a call to the priesthood. He would eventually be appointed to be the national advisor for the JUC in 1961 and served as a sympathetic supporter and advocate for the university movement. ${ }^{87}$

Another future leader of the Brazilian JUC was to become even more influential in the long term development of the Catholic student movement in Brazil. Father Romeu Dale began working with JEC (the secondary school student movement) in 1945 after coming under the dual influence of the French Dominican economist Padre Lebret, ${ }^{88}$ and Joseph Cardijn's Young Christian Workers group in 1942. After studying for the priesthood, he became a Dominican priest, was appointed to be the national advisor to the JUC in Rio de Janeiro in 1949, and continued in the role of national advisor to the organization until his resignation in $1961 .{ }^{89}$ From the beginning Dale was in favor of mentoring students through active personal engagement with real social issues which he called "formation in action" (a Brazilian term for the See-Judge-Act method) His style of leadership was nuanced and affirming of young people, giving them much room to undertake their own initiatives. Those that worked with him remember his attempts to always arrive

\footnotetext{
${ }^{86}$ Luis Edwardo Waldemarin Wanderly, Interview, Programa de Documentação Oral (Säo Paulo, Brazil: C.I.D.E.C., September 27 1988).

${ }^{87}$ Padim, Interview: May 28, 1990.

${ }^{88}$ Louis Joseph Lebret (1897-1966) was a French Dominican priest who founded the research center, "Economy and Humanism" in 1942 to encourage socially responsable economic development in the third world. He combined Catholic social teaching with modern economic analysis in order to develop ideas for ethical economic development. His publications and ideas were very influential in Brazil, Colombia, Venezuela, Lebanon, and Senegal. See L. J. Lebret, Homenaje a L. J. Lebret (Lima: Editorial Universo, 1969).

${ }^{89}$ Romeu Dale, Interview with Olga Brites and Yara Aun Khoury, Progama de Documentação Oral (São Paulo, Brazil: C.I.D.E.C., April, 13, 1993).
} 
at incisive positions, frequently provoking strong reactions among young leaders in order to stimulate discussion and fresh ideas. ${ }^{90}$

Other student leaders who were involved with JUC from an early date included Frei Carlos Josaphat, the future editor of Brasil Urgente, who joined in 1946, and Darcy Passos, who joined JUC in 1945 through the invitation of a friend of one of his sisters when he was studying in a public high school. ${ }^{91}$ Paulo de Aroucha Cotrin became involved with the JUC in 1946 when he entered the Faculty of Law in São Paulo. When he graduated, he opened the first Student's House connected with Catholic Action. He also led the JEC until 1957, when he left Catholic Action because of his disenchantment with its politicization. ${ }^{92}$

During the early years of the JUC there were a variety of ideological influences, both conservative and progressive. The most conservative influence was the Brazilian Integralist movement which was traditionalist, corporatist and enamored with Mussolini's fascism. Before the war, many bishops were sympathetic with the Integralists. One scholar estimates that as many as thirty percent of the bishops supported this expression of Brazilian proto-fascism which promised "order, stability, and patriotic integration." 93 After 1945 fascist themes fell out of favor and many of the bishops refocused themselves

\footnotetext{
${ }^{90}$ Dale, interview, 1993; Souza, $A J U C: 89$ and 94.

${ }^{91}$ Frei Carlos Josaphat, interview, March 12, 1997; Darcy Passos, interview, October 18, 1988.

92 Paulo de Aroucha Cotrin, interview, January 24, 1990.

${ }^{93}$ De Kadt, "Religion,” 207.
} 
increasingly on the urgent need for social and economic reforms. The Integralists began to lose influence and eventually departed from Catholic Action. ${ }^{94}$

In the postwar period, the sources of Catholic intellectual influence in Brazil were people such as the French philosopher, Jacques Maritain, who strongly influenced Alceu Amoroso Lima, Brazil's leading Catholic thinker, and the original leader of Catholic Action. ${ }^{95}$ Other influences besides Maritain and the aforementioned Padre Lebret, included Emmanuel Mounier, founder of the French journal Esprit, and the evolutionary thought of Teilhard de Chardin. Mounier's book, Personnalisme became required reading for many students in Catholic Action's youth movements. ${ }^{96}$

After the Second World War, the Brazilian Catholic university movement began to restructure itsef. New organizational statutes were formulated in 1947 in São Paulo at the National Week of JUC (Semana Nacional da JUC). Although these new statutes were still derived from the generalized Italian model, they specifically permitted the introduction of new approaches from France, Belgium, Canada, precisely the Francophone countries where Cardijin's specialized Catholic Action was pioneering the "See-Judge-Act" method. ${ }^{, 97}$ The Brazilian form of the Catholic university movement would soon be deeply influenced by the specialized branch of Catholic Action.

${ }^{94}$ Padim, interview, May 28, 1990; Souza, A JUC: 96.

${ }^{95}$ Bidegain, Participación y Protagonismo: 88.

${ }^{96}$ De Kadt, "Religion," 205. According to De Kadt, Henrique C. de Lima Vaz, SJ should be included as a key intellectual influence from within Brazil itself. He wrote on the secular philosophies of history (Hegel, Marx) as well as on the encyclical letters of Pope John.

${ }^{97}$ Souza, A JUC: 87 and 96; Della Cava, "Catholicism," 40. 
There were many examples of transnational intellectual exchange early in the development of the JUC. Several French Canadian priests arrived in Brazil with previous experience in specialized Catholic Action's work with students. ${ }^{98}$ There were also Brazilian priests who had participated in the pre-war student movements and went to France to study for the priesthood. Father Romeu Dale, the national advisor to the JUC, went to France for nine years to prepare himself for ordination as a Dominican priest. Another Brazilian priest was Carlos Josaphat who studied in Toulouse, France in 1953 for his ordination as a Dominican. He spent an additional two years in France working and assisting homeless Portuguese immigrant workers. He also provided theological assistance to an agrarian movement in France. ${ }^{99}$ Josaphat also later launched a radical left Catholic journal in São Paulo called Jornal Brasil Urgente. ${ }^{100}$

In 1947, Dom Hélder Câmera was named the national assistant (clerical advisor or chaplain) to Brazilian Catholic Action. Hélder Câmera was also the organizer of the CNBB, the National Council of Brazilian Bishops and was the most noted advocate of the Brazilian poor in the postwar period. He favored and supported the evolution of the Catholic Action movement from the parish-based Italian model in the direction of the missional sodalities of specialized Catholic Action. ${ }^{101}$ The institutional support given to the Catholic students by Hélder Câmera and Romeu Dale was crucial in its development

\footnotetext{
${ }^{98}$ Dale, interview: April, 13, 1993.

${ }^{99}$ Frei Carlos Josaphat, interview, March 12, 1997.

${ }^{100}$ Josaphat, interview, March 12, 1997.

${ }^{101}$ Souza, $A$ JUC, 63.
} 
into a significant influence on the national scene. Nevertheless, the implementation of the Franco-Belgian specialized methods did not come easy in Brazil. Not all of the Bishops were enthusiastic about it and in some cases they forbade their priests from participating or lending their support. Some religious orders, such as the Jesuits, were leery and saw in specialized Catholic Action potential competition for other initiatives such as the Jesuitled Marian Congregations. ${ }^{102}$ Institutional competition and jealousy was as much a Catholic as well as a Protestant phenomenon.

It was not only those studying for the priesthood who were exposed to transnational influences. Three lay leaders attended a conference in Montreal where they met Joseph Cardign and they invited him to visit Brazil. ${ }^{103}$ In 1948, three Brazilian students, two young women and one young man, attended the first meeting in Chicago of the JECI, the international wing of the specialized form of Catholic Action for students. The following year, two students from Brazil were sent to the Congress of Pax Romana in Mexico. ${ }^{104}$ Joseph Cardign visited Brazil twice in the late 1940s. In 1950, a large group of Brazilian working youth traveled to Belgium to attend an International conference of the Young Christian Workers. ${ }^{105}$ Throughout the early 1950s, numerous Brazilian students were provided with opportunities to travel to attend congresses, conferences and seminars

${ }^{102}$ Bidegain, Participación y Protagonismo: 87.

${ }^{103}$ Ibid., 91 .

${ }^{104}$ See the note on Pax Romana on page 59, footnote 91. JECI was influenced by Emmanuel Mounier's personalist philosophy of action. The two organizations were merged into one international coordinating agency in the late 1960s.

${ }^{105}$ Bidegain, Participación y Protagonismo, 92. 
in Europe, Africa and other parts of Central and South America. The experience of the Brazilian JUC was not isolated but emerged in a transnational context. ${ }^{106}$

One of the two young women sent to Chicago in 1948 was named Fernanda Moraes Sarmento. ${ }^{107}$ Fernanda was credited to have brought the emphasis on specialized Catholic Action back to Brazil after the meeting in 1948 and to have assisted with its implementation which led to profound changes of the Brazilian JUC. A Canadian student leader, Fernand Cadieux (JEC) was also instrumental in helping the Brazilian JUC discover intellectual tools of analysis and action that characterized specialized Catholic Action. $^{108}$

As noted earlier, specialized Catholic Action was characterized by a simple method of consciousness formation using the See-Judge-Act method. ${ }^{109}$ The See-Judge-Act method focused first on careful observation of "concrete reality", including social and economic facts and then moved to the application of spiritual and biblical discernment of these realities, and finally resulted in concrete action based on the observation and analysis. From the beginning, the specialized Catholic youth movements such as JOC and JUC emphasized the importance of concrete action rather than abstract theory, but this emphasis on praxis became even more notable in Brazil in the mid-1950s. ${ }^{110}$ A former member

\footnotetext{
${ }^{106}$ José Oscar Beozzo, Cristãos Na Universidade e Na Politica (Petrópolis: Editora Vozes, 1984), 36, 54-55.

${ }^{107}$ Bidegain, Participación y Protagonismo, 95.

${ }^{108}$ Luiz Alberto Gómez de Souza, “JUC, Movimento Pedagógico,” working document: 2, Bidegain Papers.

${ }^{109}$ See page 53 .

${ }^{110}$ Mainwaring, “A JOC,” 38.
} 
of the JUC, Arselina Ribeiro de Araújo, recalled in an interview that she already had a religious background, but it was only after she went through the See-Judge-Act training in the JUC that she began to develop an activist perspective. She later applied what she had learned from the JUC consciousness-raising in working with Brazilian educator Paulo Freire in the base education movement (MEB). ${ }^{111}$

The Brazilian JUC was composed of teams of 'militants,' organized by faculty (academic department or specialization) and sometimes by cohort in the university. In the beginning, JUC (masculine) and JUCF (feminine) were separate movements but later were among the first movements to be consolidated and become gender integrated. Each team of militants had a leader (dirigente) and the dirigente herself was part of a team of leaders. There was also a national team which met annually in a national counsel, as well as sometimes regional teams. There were also "pilot teams" in different faculties. The national team began in 1952 in Rio de Janeiro. ${ }^{112}$

The Brazilian Catholic university movement grew in influence throughout the 1950s. As previously mentioned, Dom Hélder Câmera formed the CNBB (Nation Brazilian Bishops Conference) in October of 1952. That same year, a national coordinating

\footnotetext{
${ }^{111}$ Ribeiro de Araújo, interview, Programa de Documentação Oral (Säo Paulo, Brazil: C.I.D.E.C., July 26, 1990). Paulo Freire (1921 - 1997) was an influential Brazilian educator and an advocate of critical pedagogy. He studied the psychology of language at the University of Recife and was appointed Director of the Department of Education for the State of Pernambuco. In 1961, he was the head of the Department of Cultural Extension of the University of Recife and successfully oversaw a project in which 300 illiterate sugar cane workers learned to read in 45 days. The Brazilian government in partnership with Catholic Church used Freire's methods to form the base education movement (MEB) in an attempt to bring literacy on a large scale to Brazilian peasants. When the military overthrew the government in 1964, Freire was jailed for nearly two months and exiled. The MEB experiment was ended. Freire published his best known book in 1968: Paulo Freire, Pedagogy of the Oppressed (New York: Continuum, 2000).

${ }^{112}$ Souza, A JUC, 87.
} 
group was formed for the Brazilian Catholic university movement in Brazil. ${ }^{113}$ A continental coordinating center was also formed for all of Latin America, in Lima, Peru but was later moved to Rio de Janeiro. ${ }^{114}$ By the later part of the 1950s, a Brazilian student leader, Gómez de Souza, eventually rose to the position of General Secretary of the JECI, the Paris-based International Secretariat for the JEC movement. ${ }^{115}$ The Brazilian university movement began to exercise considerable influence, not only within Brazil but also regionally and internationally.

The Brazilian JUC developed rapidly in the 1950s. There were sixty "base" teams of the JUC working in over one hundred faculties in sixteen universities in Brazil in 1953. Soon, meetings of the JUC began to include discussion of the social problems in Brazil although only in a cursory way in the beginning. There was also a move toward regional decentralization. By the following year, the student leaders of the JUC were asking the clerical advisors for guidance on the issue of political engagement. ${ }^{116}$

According to Gómez de Souza, in some cities, the JUC and the JUCF (The female student organization before the two were merged) were primarily centers of religious and spiritual formation in the mid-1950s; in others, such as in São Paulo, they were in the early stages of transformation into activist movements which sought to address social

${ }^{113}$ Padim, interview: May 19, 1990; Souza, A JUC: 63

${ }^{114}$ JEC stands for Juventude Estudiante Catolica in Portuguese or Jeunesse Etudient Catolique in French and was the secondary school version of the JUC. Secondary students in JEC often moved on to JUC when they entered university studies. In some countries, such as Canada, the acronym "JEC" was used generically for both university and high school students. Thus, occasionally JUC and JEC are used interchangeably, one meaning Catholic University students, and the other meaning Young Catholic Students.

${ }^{115}$ Padim, interview: May 18, 1990. 
problemes in Brazilian society (meios da vida). Luis Edwardo Waldemarin Wanderly, a former student leader of JUC who was interviewed in 1988, recalled that in the early 1950s the majority of JUC members focused on the internal workings of the church and, even as late as 1955 , there were only a few student members that were becoming politically radical. Nevertheless, by the late 1950 s, the pressure to become politically engaged had greatly intensified. ${ }^{117}$

The first Regional Encounter of the specialized student organizations in the Southern Cone countries took place in 1954 in Asunción, Paraguay. The JEC International Council (JECI) in Paris was re-structured and published a document called "Common Foundations" (Bases Comuns) detailing the common values and practices of the various national Catholic university student organizations within its sphere of influence. ${ }^{118}$ From this point on, the Brazilian JUC began to work less with the intellectual and anticommunist Pax Romana and more closely with the activist JECI in Paris. ${ }^{119}$

Clerical or ecclesiastical 'assistants' (chaplains) were appointed by the bishops to advise the students at the national, regional and city levels. The assistants were frequently regular clergy from among the Dominicans, Franciscans or occasionally the Jesuits. Because the chaplains often remained closely involved for several years, they brought a formative theological and ideological influence in the university chapters. Throughout the

\footnotetext{
${ }^{116}$ Beozzo, Cristãos, 38-40.

${ }^{117}$ Luis Edwardo Waldemarin Wanderly, interview, Programa de Documentação Oral, (São Paulo, Brazil: C.E.D.I.C., September 27, 1988).

${ }^{118}$ Jean-Louis Janot, memorandum of the General Secretary of JECI to the Director of Pax Romana, (1956) 1, Bidegain Papers.; JECI, "Bulletin International," (1956): 3, Bidegain Papers.

${ }^{119}$ Beozzo, Cristãos, 55.
} 
1950s, the national advisor was Father Dale, himself a former student militant and a Dominican priest. ${ }^{120}$

From the mid-1940s through 1956, coinciding with the postwar period and through the early part of the Cold War, Catholic university student movements sprang up in multiple countries in North and South America. The national university movements in Brazil and Cuba were loosely associated with one of two forms of Catholic Action. The Cuban university movement was mostly closely connected to the general Italian model of Catholic Action which originated under Pope Pius XI in Italy. The Brazilian university movement after 1946 became more involved with the specialized form of Catholic Action inspired by the young Christian workers movement in Belgium and the university student movements in France and Quebec. Both the Brazilian and the Cuban university movements were autochthonous, in the sense that they were originally organized at the national level. Nevertheless, most university student movements eventually formed transnational affiliations with one of two international coordinating agencies located in Europe: Pax Romana located in Switzerland, and the Young Catholic Students International (JECI) in Paris. Each organization worked with a different set of priorities and organizational guidelines. As mentioned earlier, Pax Romana's overriding priority was to stem the growth of communism among students. JECI, on the other hand, was motivated to mobilize Catholic students to pragmatically address social problems in the developing world. ${ }^{121}$

${ }^{120}$ Souza, A JUC, 88.

${ }^{121}$ Bidegain unpublished paper. 
The oldest Cuban university movement (ACU) came into existence before World War II and was primarily influenced by the generalized Catholic Action model and Pax Romana, and functioned under the oversight of the Marian Congregations with Jesuit chaplains. ${ }^{122}$ The young Christian workers movement only arrived in Cuba near the end of the Second World War, and the Cuban clergy took steps to modify and restrict the influence of specialized Catholic Action in the student and university movements. Cuban Catholic university students traveled to international conferences in the 1950s and interacted with Catholic students from Europe and other countries in Latin America, the U.S. and French Canada. ${ }^{123}$ Although there were some minor steps toward implementing specialized Catholic action methods in Cuba, the Cuban university movement continued to be largely influenced by Italian-style general Catholic Action and Pax Romana. ${ }^{124}$

The Brazilian Catholic student movement began in the 1930s under the general aegis of Catholic Action. Many of the significant leaders of the university movement in the postwar period were themselves student university leaders in the 1930s and 1940s. ${ }^{125}$ The postwar Brazilian Catholic university and student movements (JUC and JEC) began incorporating elements of specialized Catholic Action, by way of French Canadian Catholicism, as early as 1948 and gradually reoriented their methods and philosophy around the specialized Catholic Action philosophy of the JECI in Paris. This organizational tran-

${ }^{122}$ La Quincena, March 30, 1955: 6, 40.

${ }^{123}$ Letters: March 28, Abril 13, and May 12, 1956. Bidegain Papers.

124 Hermano Victorino, "Message to the National Assembly of the Federation of Catholic Action Youth,” (1953), 2: Arcebispado.

${ }^{125}$ Dale, interview, April, 13, 1993; Padim, interview, May 28, 1990. 
sition coincided with a period of developmental crises in Brazilian society. The Brazilian JUC was encouraged to by their national leaders and international influences to overcome the sacred/secular divide and to engage the secular Brazilian academic sphere with Catholic influence. Faith, in the context of the Brazilian JUC, was no longer solely parish-based, nor was it solely a matter of pius liturgical reflection. Faith was to be dynamically lived out through practical social action in the secular sphere. Thousands of young Brazilian Catholic university students were trained through the See-Judge-Act process to become political activists on behalf of their Catholic faith

At the conclusion of the Second World War there was a surge of generational consciousness in most Western societies. As the Cold War was beginning, university student movments became politically and socially active in numerous nations. Transnational student unions were formed in Europe, ostensibly to prevent a reoccurance of fascism, but were quickly drawn into the polarized environment of the Cold War and fragmented into competing Eastern-bloc Marxist and Western pluralist-democratic student organizations. The Catholic Church, not to be outdone, quickly inserted itself into the university milieu on the international stage. With fascism largely eliminated (but not Spanish falangism), the church's primary ideological competitor was authoritarian and integrist Marxism, although the church continued to express some degree of discomfort with, and critique of, liberal capitalism. Catholicism continued to hold forth the social teaching of the church as an alternative third way for Western civilization, but the question was which third way? Apart from the church's ideological struggle with its external competitors, ideological and theological differentiation was notable within the various streams of Catholic Action lay movements such as between Italo-hispanic and Franco-Belgian vari- 
ants. As the tide of university student activism rose in Ibero-America, these distinct ideological and theological influences within Catholicism had differing levels of influence in nations such as Brazil and Cuba. In a set of social and economic problems common to developing nations in the third world, Catholicism offered several different versions of the Catholic third way through the activism of its students. When these varying forms of Catholic Action interacted with very different geo-political situations, widely divergent ideologies resulted. 



\section{CHAPTER IV}

\section{THE CATHOLIC STUDENT MOVEMENT IN CUBA: 1953 TO 1962}

The Church in Cuba faced unique historical challenges in the pre-revolutionary years of the Batista dictatorship. Like the Catholic Church in other countries of Latin America, the church in Cuba found itself challenged by the macro-historical process of expansive modernity and growing religious pluralism in the first part of the twentieth century. By mid-century the Church found itself caught on the horns of a dilemma: to support the authoritarian regime of Fulgencio Batista in order to maintain some level of influence with the state, or to consciously assume a role of moral and political opposition, and possibly even support Fidel Castro’s 26 of July movement.

A key element of the Church's response to both modern pluralism and state authoritarianism was to create lay organizations of men, women, workers and students. ${ }^{1}$ Chapter IV examines the social and political roles of the Catholic clerical hierarchy and Catholic lay organizations (called Catholic Action), during the Batista regime and the Cuban Revolution. The Catholic hierarchies in other Latin American nations of this same period attempted to utilize Catholic lay organizations to respond to varying structural relationships with the state as a strategy to counter their loss of influence at the state level and to maintain Catholic influence in the social and public spheres in what has been called neo-Christendom. ${ }^{2}$

\footnotetext{
${ }^{1}$ Lay organizations within the Catholic Church were started in the 1920s and 1930s as an attempt to mobilize lay people (non-clerical) to act as faithful Catholics within secular and civil society. From the Greek laos (people).

${ }^{2}$ Angela Randolpho Paiva, Católico, Protestante, Cidadão: Uma Comparação Entre Brasil e Estados Unidos (Belo Horizonte, Brazil: Editora UFMG, 2003), 221. For a definition and discussion of neo-Christendom, see Daniel H. Levine, Religion and Politics in Latin America: The Catholic Church in
} 
Chapter IV will address the reasons why the Catholic Church in Cuba vacillated between support for the Cuban Revolution and tacit acceptance for Batista's dictatorship, and to what extent this vacillation represented a state of flux in the ideology of traditional Catholicism itself? A related question is to what extent did student members of Catholic lay organizations contribute to the development of the Cuban Revolution? And to what degree did the Church hierarchy make room for the political pluralism of the Catholic lay organizations?

Catholicism in Cuba was traditionally weak, particularly in the eastern part of the island. Catholicism also suffered during the wars of independence because of its identification with Spain, while Protestantism came to be seen by some as authentically Cuban and patriotic. After Independence from Spain, Protestant missions grew rapidly under U.S. cultural hegemony, thus placing Cuban Catholicism in a defensive role. ${ }^{3}$ It was in this context that the Cuban bishops encouraged the development of Catholic lay organizations in the 1930s and 1940s. In the early 1950s, the Cuban Catholic Church found itself faced with the challenge of how to respond to General Batista's illegal seizure of power and dictatorship. The Cuban hierarchy faced a particularly delicate task of navigating between opposition to Batista while at the same time attempting to maintain influence with the Cuban state. During this same period, Church representatives wrestled with the need to interpret the Church's social teaching and to find a 'third way' between the materialis-

Venezuela and Colombia (Princeton, NJ: Princeton University Press, 1981), 33, 304, and Alexander Wilde, Creating Neo-Christendom in Colombia (Notre Dame, IN: University of Notre Dame Press, 1987), 3.

${ }^{3}$ Yaremko, Missions in Cuba (2000); Louis A. Pérez, Jr., On Becoming Cuban: Identity, Nationality, \& Culture (New York: Ecco Press, 1999); Louis A. Pérez, Jr., Cuba: Between Reform \& Revolution (Oxford University Press, 1995); Luis Martínez-Fernández, Protestantism and Political Conflict in the Nineteenth-Century Hispanic Caribbean (New Brunswick, NJ: Rutgers University Press, 2002). 
tic individualism of capitalism, and 'atheistic' communism. ${ }^{4}$ Many of the articles in progressive Catholic magazines, in addition to the letters and circulars of the bishops of this period, reflect this vacillation between capitalism and communism, between the Batista regime and the revolutionary impulse. ${ }^{5}$

Ideological formation and International Influences

The mid-1950s was a period of rapid change and deteriorating social conditions in Cuba. Fulgencio Batista, who had seized power in 1952, was elected president with no opposition in a rigged election, and was inaugurated in 1955 with the apparent blessing of the Eisenhower administration. In April, he declared political amnesty and released Fidel Castro from prison. Castro went into exile in Mexico. Shortly after Castro's exile to Mexico, a group of university of Havana students organized the Revolutionary Directory with the goal the overthrow of Batista and a return to the Constitution of 1940. There were significant developments within Catholicism as well. The Franciscan order in Cuba changed the name of their bi-weekly magazine from "Semanario Católico" to "La Quincena" and adopted a more contemporary format with the motif: "A Christian answer for today's problems."

The director for the new progressive journal was Father Ignacio Biaín, a Basque priest from Spain. The Basques had fought for the Spanish republic on the losing side of the Spanish Civil War and tended to be more liberal than the typical Spanish priest. Father Biaín was socially liberal as were a score of Basque Franciscans who were refugees

\footnotetext{
${ }^{4}$ Manuel A. Vásquez, The Brazilian Popular Church and the Crisis of Modernity (Cambridge, UK: Cambridge University Press, 1998), 21.

${ }^{5}$ La Quincena, August 1956, 32-35.
} 
from Franco's Spain. ${ }^{7}$ As a clandestine insurrection against Batista began to mount, Father Biaín maintained contact with the insurgents and supported the Cuban Revolution through the closing of the La Quincena in 1960 by his Franciscan superiors. He died in Havana in $1963 .^{8}$

From the very first issue in February of 1955, La Quincena included articles and editorials reflecting catholic criticism of the social inequities of laissez-faire capitalism. On page five, there was an article quoting the Cardinal Primate of Spain, Enrique Plá y Daniel (1876-1968), about the need for the church to be sensitized to the plight of the working classes, despite the cardinal's conservatism and support for Franco during the Spanish Civil War. On page seventeen, there was an article quoting Pope Pius XII in his criticism of both capitalism and socialism as well as information on the "hogar Católico Universitario" (Catholic University home) which had been started by Hermano Victorino, the missionary priest who was the head of the Catholic Action youth in Cuba. On page 32, there was an article about General Batista's new administration, and urging people to withhold judgment and give the new government time. ${ }^{9}$

The following issue opened with a much more critical tone of Batista's administration and pointed out that the Constitution of 1940 could have been a point of stability to help calm the nation. The author said that Cuba was becoming an unstable country of

\footnotetext{
${ }^{6}$ Fernández Santalices, Cuba, 54.

${ }^{7}$ Raúl Gomez Treto, La Iglesia Católica Durante la Construcción de Socialismo en Cuba (San José, Costa Rica:: DEI: Departamento Ecuménico de Investigaciones, 1987), 30.

8 “CUBA: The Awakening Church,” TIME Magazine, November 281960.

${ }^{9}$ La Quincena, February 15, 1955; Manuel Arteaga, "Hogar Catolico Universitaria,” Cuban Catholic Action (Havana: 1950), Arcebispado.
} 
gangsters. He criticized the weakness of the government and predicted the rise of an armed insurrection. Despite the apparently friendly relations between Batista and the top officials of the church, La Quincena revealed a more critical attitude among church progressives about the disregard of constitutional government. ${ }^{10}$

In March, La Quincena reported on a Catholic Congress in Mexico that was once again critical of both capitalism and communism (a repeated theme of twentieth-century Catholicism, which acquired even greater significance during the Cold War). A subsequent article discussed the work of Pax Romana in Cuba with Catholic university students, naming four different Catholic university organizations active in Cuba: the ACU (Agrupación Católica Universitaria) under the chaplaincy of the Jesuits, the Union of University Catholics (UUC) and two branches (male and female) of the specialized JUC (Juventud Universitaria Católica) under the guidance of the Franciscan order. The first two organizations were under the umbrella of the Marian Congregations and the JUC was affiliated with Cuban Catholic Action. ${ }^{11}$ In April, the political situation of the country appeared to deteriorate. La Quincena reviewed the various political groups and reported that the aforementioned insurrectionist movement, el "Movimiento de Liberación Radical' (MLR) had been started by a group of young Catholic Action members. ${ }^{12}$

Articles in La Quincena hinted at the possibility of political conflict within Catholicism itself that may have reflected the tensions between conservatives and social

\footnotetext{
${ }^{10}$ La Quincena, February 28, 1955.

${ }^{11}$ La Quincena, March 30, 1955: 6, 40.

${ }^{12}$ La Quincena, April 15, 1955: 6, 40.
} 
progressives within the church. The author of an article in May pointed out that there was occasionally a lack of harmony even within the realm of the apostolate on both the national and the international levels. Most likely this was a veiled reference to tensions between Italian-style, general Catholic Action (represented by Pax Romana among students on the international level) and the newer Franco-Belgian specialized Catholic Action, represented by the JUC and the JEC in Cuba. On the international level, there were overlapping jurisdictions between Pax Romana and the specialized JECI, as well as differing social and political priorities. ${ }^{13}$ The article called for an end of prideful vanity, gossip, criticism, boycotts of initiatives and the "foisting of ignorance upon others." 14

There appeared to have been some tension in Cuba as well over the implementation of the newly arrived specialized method of Catholic Action. The national spokesperson for specialization, Dr. Josefina Pérez Montez, wrote an article in the young women's bulletin in 1948, explaining the advantages of specialization and urging its adoption in Cuban Catholic Action. ${ }^{15}$ In February of 1953, Hermano Victorino spoke to the National Assembly of the Federation of Catholic Action Youth. The occasion for the Assembly was the twenty-fifth anniversary of the founding of Catholic Action in 1928. In his remarks to the Assembly, Victorino urged caution about the implementation of specialization in Catholic Action. ${ }^{16}$

\footnotetext{
${ }^{13}$ See Chapter 3, pages 76, 83-84.

14 “La Unidad que Nos Falta," La Quincena, May 30, 1955: 31.

${ }^{15}$ Josefina Pérez Montez, "Necesidad de la Especialización,” AFAN 4, no. 40 (July 1948): 5, Arcebispado.
} 
In June of 1955, La Quincena carried an article by a French poet and intellectual, Pierre-Henri Simon (1903-1972), defining progressive Catholicism. He began his essay with St. Thomas Aquinas and quickly moved to Jacques Maritain's Integral Humanism and the French philosophy of personalism. ${ }^{17}$ He believed that the various personalistic philosophies derived from Maritain had a theology of incarnation as their common basis. The author contrasts personalism, influenced by the theology of incarnation, with the nationalist and proto-fascist philosophy of Charles Murras, which he criticized as "traditional, hierarchical and aristocratic.",18

In contrast to integralist philosophies like that of Murras, Simon described the perspective of Christian progressivism as concerned about social justice, the liberation of the oppressed proletariat and the eventual establishment of a classless society. Such a form of Catholicism would be founded on intellectual collaboration with the elevation of working class values above those of the bourgeoisie and the "exaltation of the modern world rather than its condemnation." ${ }^{19}$ Simon noted that progressive Christianity was

\footnotetext{
${ }^{16}$ Hermano Victorino, "Message to the National Assembly of the Federation of Catholic Action Youth,” (1953), 2: Arcebispado.
}

${ }^{17}$ Personalism was a French philosophy that tried to combine balance Western individualism with a social concern for collective society by placing a high view on the uniqueness of the human person. Although Jacque Maritain is often considered a father of Catholic Personalism, the philosophy may be best personified with Catholic acitivist and philosopher Emmanuel Mounier, editor of the journal, L'Espirit and his book, Personalism, trans. Philip Mairet (Notre Dame, IN: University of Notre Dame Press, 2005). Mounier's writings were very influential with specialized Catholic university movements.

${ }^{18}$ Pierre-Henri Simon, “QQué son y que quieren los cristianos progresistas?” La Quincena, June 30, 1955: 10. Charles Murras was a French critic and poet and leader of the conservative and nationalist Action Française, a political movement that was Monarchist anti-parliamentarian and counterrevolutionary and to some extent a 'proto-fascist' movement. Although his movement was very influential among French Catholics, Murras himself was an agnostic and his movement was condemned by Pope Pius $\mathrm{XI}$ in 1926.

\footnotetext{
${ }^{19}$ Simon, La Quincena, June 30, 1955: 12.
} 
born in the climate of Marxism and he affirmed the need for a social revolution. He suggested that Christian doctrine should incorporate Hegelian philosophy as the basis for a Christian worker's revolution rather than a communist revolution. He noted that it is not surprising that Christian progressives, such as the aforementioned Christian Hegelians, should make the church hierarchy uncomfortable. ${ }^{20}$ Simon's pronouncements may seem very radical for their context in 1955, especially in a Catholic journal in Cuba at the beginning of the Cuban Revolution. Nevertheless, some of his suggestions, such as the need to come to terms with the modern world, would be affirmed by the Second Vatican Council just ten years later. ${ }^{21}$ The significance of his article in La Quincena is that this may reflect what many Franciscans, and other Catholic progressives, were reading and thinking in Cuba in 1955. One must keep in mind that the specialized Catholic university movement in Cuba, the JUC (Juventud Universitaria Católica) was influenced, not only by the progressive intellectual heritage of Franco-Belgian Catholic Action, but also by the chaplaincy of the Franciscan order in Cuba.

In 1955, Pax Romana sponsored a regional meeting held in Havana for Central America, Mexico and the Antilles. In the Conference report published after the meeting, Mateo Jover, a JUC student leader from Cuba, described the profile of a Catholic student leader. According to Jover, a Catholic student leader displays "appropriate personal qualities to assume the responsibility and leadership for the organization, carrying forth

${ }^{20}$ Ibid., 47.

${ }^{21}$ Kenneth P. Serbin, "The Catholic Church, Religious Pluralism, and Democracy in Brazil," in Democratic Brazil: Actors, Institutions and Processes, ed. Peter R. and Timothy J. Power Kingstone (Pittsburgh, PA: The University of Pittsburgh Press, 2000), 147. 
to the highest possible standard the ideals of the movement." ${ }^{22}$ Another Cuban student activist, Angela Esparraguerra wrote an article discussing Pax Romana's "Plan of Havana" student activities and outreach programmed for Central America, Mexico and the Antilles. Catholic lay organizations participating in the event in Havana were listed from eleven countries from Latin America and the Caribbean. The Cuban delegation included four different university organizations. ${ }^{23}$ Thirty-three members of the university movement from Cuba participated in the congress. ${ }^{24}$

Cuban Catholics were very interested in trends in Catholicism in other parts of Latin America. For example, La Quincena followed with interest the International Eucharistic Congress which was held in July, 1955 in Rio de Janeiro. There were several articles on the social problems of Brazil along with the role of Brazilian religions. ${ }^{25}$ Joseph Cardijn, the Belgian priest who founded the JOC, was in attendance in Rio de Janeiro for the Congress along with two thousand young Christian workers along with eight Cardinals, 43 archbishops and 59 bishops representing twenty-three Latin American countries. In an early anticipation of Latin American Liberation Theology, the Paraguayan Archbishop proclaimed that the mission of the Church in Latin America is to make the poor

\footnotetext{
22 "Memoria de la II Reunion," Regional Meeting for Mexico, Central America and the Antilles, (Havana, Cuba: Editorial Echevarria, 1955): 40, Bidegain Papers,

23 "Memoria de la II Reunión," (1955) 54-56. The participating student organizations were listed as the ACU (Acción Católica Universitaria), JUCF (Juventud Universitaria Católica Feminina), JUCM (Juventud Universitaria Católica Masculina), and UUC, (Unión Universitaria Católica).

24 “Memoria de la II Reunión,” (1955) 65.

${ }^{25}$ La Quincena, August 15, 1955: 30.
} 
less miserable and the rich less opulent. ${ }^{26}$ Catholic progressivism in Cuba did not arise in a vacuum but was influenced by trends in the rest of Latin America as well as Europe.

Tensions and conflict within Cuban Catholicism between conservatives and progressives continued to grow in the fall of 1955. In an editorial at the end of September, Father Biaín lamented the lack of integration of efforts among Catholics for a restoration of a constitutional political order. ${ }^{27}$ He compared the contemporary situation of 1955 as parallel with the revolutionary period of $1933 .^{28}$ In no other period of Cuban history since 1933, according to Biaín, were there such firm political commitments among Christians as a consequence of their spiritual faith. He asserted that it was absolutely necessary for Christians to unite their efforts. Nevertheless, he decried the division of Christians over secondary issues. He called for the creation of a political party of Christian inspiration and for Christians to lay aside their own personal criteria for the good of the country. ${ }^{29}$ Another conflict brewing in the fall of 1955 was between the specialized young Catholic workers (JOC) and the older Catholic labor organization, the National Association of Catholic Employees (ANEC: Asociación nacional de Empleados Católicos), both of which were advised by Jesuits. ${ }^{30}$ Apparently the young people of the JOC were rocking the boat by supporting employee demands and threatening a strike against their em-

\footnotetext{
${ }^{26}$ Ibid., 64.
}

${ }^{27}$ La Quincena, September 30, 1955: 33.

${ }^{28}$ Gerardo Machado (1871-1939) became Cuban dictator in the early 1930s, provoking a revolution in 1933, in which many university students were involved as well as Sargent Fulgencio Batista. The dictatorship of Machado and the uprising against him is sometimes referred to as the "Machadato."

29 “Hacia la Integración de Fuerzas,” La Quincena, September 30, 1955: 31. 
ployers in opposition to the other Catholic workers group, which according to traditional Catholic social teaching, sought to improve their lot in harmony with their employers in accordance with a corporatist vision of society. The ANEC affirmed the value of modern capitalism (in the sense of Roosevelt and Eisenhower) as the best solution for Cuba. Throughout the period of the insurrection against Batista, the young workers of the JOC were firmly opposed to Batista and in support of the Cuban Revolution. ${ }^{31}$

On Sunday, December 4, 1955, there was a brutal attack by Batistianos against student members of the FEU (the student union of the University of Havana) in front of 20,000 people in the Havana stadium. The attack was recorded and played on television. ${ }^{32}$ The editorial of La Quincena in the last issue of the year carried the Christmas message of Pope Pius XII in which he condemned both "progressive Catholics" who supported Marxism as a necessary evolutionary social stage and at the same time condemned anticommunism if it was no more than a simple a defense of liberty empty of any social content. ${ }^{33}$ Although he refrained from any direct criticis of the Holy Father, Father Biaín observed in his editorial that it was no longer possible to retreat into a "Catholic ghetto." It was necessary for Catholics to act collaboratively on behalf of the benefit of the world. ${ }^{34}$

\footnotetext{
${ }^{30}$ Joseph Gremillion, "The Catholic Movement of Employers and Managers," (Thesis: Pontificia Universita` Gregoriana, 1961), 209.

${ }^{31}$ La Quincena, February 1959, 47.

${ }^{32}$ La Quincena, December 15, 1955, 46.

33 “Diagnosis de la Hora," La Quincena, December 30, 1955: 33.

${ }^{34}$ Ibid.
} 
The following year, the editor of the conservative Diario de la Marina, Jose I. Rivero, began to involve himself in the public disputation among Catholics by attacking Freemasons on the one hand and Cuban Catholic Action on the other. ${ }^{35}$ The Diario de la Marina was perhaps the oldest Cuban newspaper, founded in 1832 and represented several generations of economic interests of the dominant and sectors of the country. Diario served as the official voice of Cuban Catholicism and was systematically critical of the popular measures of the Revolution. In the 1930s, the Diario had supported the Falangist government of Spain. Cardenal Manuel Arteaga y Betancourt, the Archbishop of Havana had recently been named symbolic president of the consulting group for the newspaper. Diario de la Marina was considered by some of the most conservative prelates of the continent as the "greatest newspaper of the world." ${ }^{" 36}$ Although both periodicals were Catholic, Diario de la Marina and La Quincena frequently supported opposing views during the course of the Cuba Revolution.

During the increasing social instability of the mid 1950s, Cuban Catholic Action remained closely affiliated with the international Catholic organization Pax Romana. As noted earlier, Pax Romana was concerned with providing an intellectual defense of Catholicism for students and intellectuals against the appeal of Marxism. Pax Romana organized large scale events on the international and continental levels which gave young Latin American and European students the opportunity to travel and to make international

${ }^{35}$ La Quincena, January 31, 1956: 36.

${ }^{36}$ Raúl Gomez Treto, La Iglesia Católica Durante la Construcción de Socialismo en Cuba (San José, Costa Rica:: DEI: Departamento Ecuménico de Investigaciones, 1987), 30. 
contacts. By way of contrast, specialized Catholic Action, represented on the international stage by the coordinating committee, JECI in Paris, was more concerned with economic and social justice issues and focused on grassroots organizing country-by-country through the use of the See-Judge-Act method.

There was abundant correspondence between Cuban Catholic Action and Pax Romana in the mid-1950s. Most of the correspondence was initiated by the young Catholic Action women's group regarding plans for a Caribbean conference to be held in Havana in 1957, and at the same time reflecting some of the deteriorating social conditions in Cuba during the revolution. Hilda López Rodriguez and Angelita Esparraguera, of the female youth of Catholic Action in Cuba, exchanged a lengthy correspondence with top leaders of Pax Romana from 1956 through 1958. Tom Kerstiëns, Secretary General of Pax Romana, wrote to Hilda López in March of 1956 about plans for a seminar of formation in Austria in July, and offered scholarships to make it possible for three female students to attend the July meeting. ${ }^{37}$ A follow-up letter from Kerstiëns to López in April inquired about the possibility of the Cuban chapter hosting and helping organize an International Assembly in Havana scheduled for August 1957. The 1957 Assembly was to include delegates from Asia, Africa and Europe as well as from the Americas. ${ }^{38}$

Kerstiëns also wrote a less formal letter to Angelita Esparraguera, Director of the Secretariat of Foreign Relations for the National Board of Cuban Catholic Action, also asking for her thoughts about hosting the International Assembly in Havana the following year and encouraging her to attend the seminar in Austria. Kerstiëns and Esparraguera

\footnotetext{
${ }^{37}$ Tom Kerstiëns to Hilda López, March 28, 1956. Bidegain Papers.
} 
had met previously at a conference in 1955 in Fribourg, Switzerland. ${ }^{39}$ Esparraguera replied in July, writing a warm and enthusiastic two page letter to Kerstiëns, informing him of a variety of news items from the Cuban university and student organizations. ${ }^{40}$ Kerstiëns thanked her and informed her that the Pax Romana had officially determined that the International Assembly for 1957 would be held in Havana. ${ }^{41}$ Because of the rapid descent of Cuba into a civil war and a social revolution, the International Assembly was not held in Havana, and was eventually moved to San Salvador.

During this same period, La Quincena frequently contained articles focused on the various branches of the specialized Catholic Action organizations. In a Quincena interview in August 1956 with the young secretary general of the JEC (founded in 1947 as the specialized outreach to Secondary School students), Raúl González Simón, affirmed that: "The JEC has entered its most important period." 42 The same interview introduced Padre Solá, who was the spiritual advisor to the JEC and who affirmed that the JEC had grown to include over twenty groups of anywhere from ten to fifty students from all over the island by 1956. In this same issue, the editorial, "The Battle for Housing," presented a socially progressive call by the progressive Catholics for state assistance in providing adequate housing for poor Cubans. ${ }^{43}$ In the news section (15 Dias

\footnotetext{
${ }^{38}$ Kerstiëns to López, Abril 13, 1956. Bidegain Papers.

${ }^{39}$ Kerstiëns to Angelita Esparraguera, May 12, 1956. Bidegain Papers.

${ }^{40}$ Esparraguera to Kerstiëns, July 10, 1956. Bidegain Papers.

${ }^{41}$ Kerstiëns to Esparraguera, August 3, 1956. Bidegain Papers.

${ }^{42}$ La Quincena, August 1956: 32-35.

${ }^{43}$ Ibid., 37.
} 
en la nación), there was an explanation of three possible political positions in response to Batista: insurrection, new elections or abstention. Fidel Castro was identified with the insurgents. Castro was quoted as saying that the 26 of July movement had decided to unite in one single front, and would act decisively this same year: "In 1956 we will be martyrs or we will be free." ${ }^{, 44}$ The overall tone of the news articles, the interview and the editorial demonstrate that the Franciscan journal was clearly supportive of Castro's attempt to overthrow the Batista government and supported basic agrarian reform.

The following month, the student president of the FEU, José Echevarría and Castro signed an agreement, called the Carta de México, combining the efforts of the Revolutionary Directory and the 26 of July movement in a united effort to overthrow Batista. In the waning months of 1956, the political situation of the country deteriorated further as violence dramatically increased. By November, the National Assembly of Catholic Action convened in the midst of "shootings, bombs, kidnappings, assaults, rumors and a collective sense of crisis." ${ }^{45}$ The November Assembly was first time a national General Assembly of Catholic Action was held in Havana, and it incorporated all the different branches of Cuban Catholic Action, including the female JECF and the male and female chapters of the JUC. ${ }^{46}$ Diario de la Marina reported that there were five hundred women in attendance and the theme was "The Mission of the Young Student in

\footnotetext{
${ }^{44}$ Ibid., 38.

${ }^{45}$ La Quincena, December 30, 1956, 69.

46 "Celebró con entusiasmo la Juventud Femenina de la Acción Católica su Asamblea Nacional," Diario de la Marina, November 27, 1956.
} 
Catholic Action. ${ }^{\$ 47}$ An overview of the See-Judge-Act method was presented by Ada Esther Garcia, President of JEC in Havana. There were representatives from all of the universities of the Island. ${ }^{48}$ Father Biain was given an award for his editorial efforts at the Catholic Action Assembly. Shortly after the close of the General Assembly, on November 30, a revolution broke out in Santiago de Cuba and rebels took temporary control of the city. A few days later under the cover of the general confusion Castro and eighty followers landed in Cuba. ${ }^{49}$

Despite Hermano Victorino's reticence about incorporating the class-based methods of specialized Catholic Action in 1953, by 1957 the specialized university and secondary school organizations were growing and active. One of the best descriptions of the See-Judge-Act method is found in the July-August JUC bulletin, Bulletin de la Dirigente. The Young women's Catholic Action had started using the See-Judge-Act method in 1954. Why was it a good method? Among several other reasons given in the bulletin, the author observed that it awakened concern for social, student and family problems that might develop in one's life, it developed a desire to serve one's neighbor and it often awakened a desire for apostolic work. In addition, it sensitized the young person to the immense needs in their sphere of life. The Spanish word used for the French milieu was "ambiente" (sphere of life or social sphere): "it is the sphere of life where the person develops or carries out his activities. ${ }^{, 50}$ In many cases, such as the young Catholic workers,

\footnotetext{
${ }^{47}$ Diario de la Marina, November 27, 1956.

${ }^{48}$ Ibid.

${ }^{49}$ La Quincena, December 30, 1956, 56-74.
} 
the ambiente was equivalent to their social class. There was an ensuing discussion about how to proceed through the three steps of personal inventory. The first step was always to analyze one's social medium or "ambiente." Three things were necessary to arrive at accurate judgements: (a) to be very careful in observation; (b) to have a point of comparison (using Christian doctrine) and; (c) to make a decision about what "should be." ${ }^{, 51}$ This was necessary in order to develop the tactics or action items one will pursue. Once a purpose or conclusion is reached within the study circle, it is vitally important that it be put into practice immediately in an organized fashion. It would appear that despite the pervasive influence of Pax Romana in Cuba, specialized Catholic Action was growing and quietly making progress by 1957.

With a full blown revolution going on, Pax Romana quietly made the decision to relocate the proposed International Assembly from Havana to San Salvador for the summer of $1957 .{ }^{52}$ Angelita Esparraguerra attended the Assembly in El Salvador along with Javier Calvo of ACU, Angelita Lavernia, Teresita Pulido, Maria del Carmen Elu, and Ada Esther García and Raúl González Simón (JEC) and Martha Díaz and Manolo Fernández (JUC). ${ }^{53}$ Apparently, on the basis of later correspondence, Esparraguerra had the opportunity to talk in person with the Secretary General Kerstiëns while there. The next letter from Angelita Esparraguera was just a few weeks after the International Assembly in El Salvador in August of 1957. Esparraguera wrote to Kerstiëns vividly

\footnotetext{
50 “Movimiento Especializado JUC," Bulletin de la Dirigente, July-August 1957: 14.

51 “Movimiento Especializado JUC," 14.

${ }^{52}$ Esparraguera to Kerstiëns, February 1, 1957. Bidegain Papers.

${ }^{53}$ Fernández Soneira, Estrella y la Cruz, 399.
} 
expressing her distress about Batista's government creating complications for the conference that forced it to be moved to another location. She described the situation in Cuba as grave and being much worse than before her trip to El Salvador. The shops were closed and the streets were empty, due to the Molotov cocktails and incendiary bombs. She herself had ceased to go out of her home other than to attend Catholic Action meetings. ${ }^{54}$

Involvement in the Catholic student movements in Cuba provided young women with opportunities for development into organizational and leadership roles, public speaking and opportunities for travel to Europe and other countries in Latin America. These young women participated in organizing conferences, giving lectures, and planning and administration for their organization at the national as well as local levels. Javier Calvo, the former young student leader from the ACU who attended the International Assembly of Pax Romana the previous summer, was brutally killed in December 1957..$^{55}$ In the early months of 1958 there were more deaths among militant Catholic students opposing the Batista regime. During the course of 1958, both female and male students were swept into the revolutionary fervor against Batista and in favor of revolutionary change in Cuba. Catholic women students became involved in organizing and sending supplies to Catholic priests serving with the rebel troops.

\footnotetext{
${ }^{54}$ Esparraguera to Kerstiëns, August 21, 1957. Bidegain Papers.

${ }^{55}$ Fernández Soneira, Estrella y la Cruz, 399.
} 
The Cuban Revolution, 1956-59

Castro, along with the men who accompanied him, nearly did become martyrs at the close of 1956, during a delayed landing at the wrong location on the south Cuban coast after a series of mishaps. Of the 80 -some men on board the "Granma," only twelve (with eleven weapons) evaded death or capture in the first days in Cuba. Early in the campaign in the Sierra Maestra, a number of priests accompanied Castro and his guerrilla band, including Father Guillermo Sardiñas who eventually became a commander and a member of the revolutionary government. Sardiñas was one of the first of at least eleven priests to join the insurrection and notably continued to support the revolution after other priests had gone into exile. ${ }^{56}$

In 1957, more Catholics activists began joining Castro's insurrection, especially after the failure of the DR (Revolutionary Directive) attack on the Presidential Palace in March. In this same student uprising, former Catholic student leader and activist, José Antonio Echevarría was tragically killed, thus depriving the Cuban Revolution of a Catholic and democratic alternative to Fidel Castro. ${ }^{57}$ Enrique Canto, President of Catholic Action in Santiago de Cuba, was appointed to be the national treasurer for the 26th of July Movement. Father Sardiñas went to the Sierra Maestra with permission from his bishop to join the guerrilla troops and to serve as a chaplain. He was soon followed by other priests. It was in this context that Archbishop Pérez Serantes issued an open letter, "To the People of the Eastern Cuba" in which he called upon all Catholics to pray for a peace-

\footnotetext{
${ }^{56}$ Meier et al. 1995, 340; Fernández Santalices, Cuba, 66-71; Fernández, 2000, 72, cited in Falcon, 2002, 80 .
} 
ful resolution of the Revolutionary violence. ${ }^{58}$ At the end of July, Frank País was killed in Santiago de Cuba. With the death of País and Echeverría, two out of three prominent leaders of the insurrection were eliminated, leaving Fidel Castro to dominate the postRevolutionary scene. ${ }^{59}$

In February of 1958, the Juventud de Acción Católica published a manifesto about the crisis of the country and called for a return to a state of law (Régimen de Derecho). Concurrently, three militants of the JAC and four from the ACU (Agrupación Católica Universitaria) were found dead with signs that they were brutally tortured. Cardinal Arteaga, and six of the leading bishops of Cuba, including Archbishop Pérez Serantes, issued a circular letter calling for an end to hostilities and the formation of a government of national union, as an alternative to the continuation of revolutionary violence, but their appeal was quickly rejected by Fidel Castro. ${ }^{60}$

In repeated circulars and letters in March and August, Archbishop Pérez Serantes continued to appeal for a cessation of hostilities. On October 7 in his circular "Macabre Passage" (Paseo macabre), he condemned the desecration of the body of a young rebel and appealed that such dehumanizing acts be repudiated in order to take steps "in the path that leads to the deeply desired peace...in a genuinely Christian spirit." ${ }^{\text {61 }}$ His final written

${ }^{57}$ Fernández Santalices, Cuba, 56; Bonachea and San Martín, The Cuban Insurrection, 119.

${ }^{58}$ Obispos Católicos de Cuba," La Voz de la Iglesia”: 38. Translated by the author from the Spanish "Al Pueblo de Oriente."

${ }^{59}$ Bonachea and San Martin, The Cuban Insurrection, 146; Yaremko, Missions in Cuba, 145.

${ }^{60}$ Fernández Santalices, Cuba, 57-58; “Obispos Católicos de Cuba,” La Voz de la Iglesia”: 39.

${ }^{61}$ Author's translation: "en el camino que conduce a la paz tan anhelada...del espiritu genuinamente cristiano." Obispos Católicos de Cuba, La Voz de la Iglesia”: 48. 
appeal to end the war on December 24,1958, was called "No More War" (Basta de Guer$r a$ ) in which he expressed his concern about hunger and the damage being done to Cuba, and ended with a desperate call for an end to the violence: "In the name of piety, in the name of humanity, for the love of God, for the good name of the Christian family, please don't continue ripping the guts out of the mother, but on the contrary, try to end this extremely painful and prolonged suffering of our people." Approximately a week later the revolution was over with the departure of Batista from Cuba. ${ }^{62}$

The new revolutionary regime came to power on a groundswell of popular support combining nationalist and revolutionary sentiment. The surge of support for the revolution created a "vast constituency for radical change...pressure for immediate, deep, sweeping change was building from below and the invocation of revolution encouraged it to rise to the top." ${ }^{, 63}$ The Catholic Church was no exception to this initial wave of revolutionary enthusiasm. Although the church hierarchy had vacillated between support for Batista and support for the insurrection in the period preceding the revolution, numerous priests and lay workers had fought in the Sierra with the July 26th movement, and saw the Cuban Revolution as an opportunity to bring about social justice for the poor and fundamental agrarian reform. ${ }^{64}$

62 " por piedad, por humanidad, por amor de Dios, por el buen nombre de la familia cristiana, procuren que no se siga desgarrando las entrañas de la madre, y que, por el contrario, traten de poner fin a esta dolorísima y muy prolongada pasión de nuestro pueblo." Obispos Católicos de Cuba, La Voz de la Iglesia": 50-52; Fernández Santalices, Cuba, 58-60.

${ }^{63}$ Pérez, Cuba: 317.

${ }^{64}$ There are affirmative references to both Castro and Guevara in the February issue of the Franciscan journal despite a somber article on the executions being carried out by firing squad. There was also 
Pérez Serantes, a personal friend of Fidel Castro, praised the revolutionary leader in his circular "Vida Nueva" (new life) as an "exceptionally gifted man" and generally welcomed Castro and the Revolution. ${ }^{65}$ The January 1959 issue of the Franciscan magazine, La Quincena, celebrated and praised the triumph of the Revolution as a "decisive and transcendental stage for Cuba. ${ }^{, 66}$ The view of progressive Catholicism as expressed in La Quincena, was clearly anti-capitalist and sympathetic to the Cuban Revolution. The journal praised revolution and "Dr. Fidel Castro" was always referred to respectfully. ${ }^{67}$ Nevertheless, there was also frequent criticism of atheistic Soviet communism, juxtaposed alongside papal criticism of the individualistic materialism of capitalism. Catholic social doctrine was positioned as a third way between the other two ideologies that divided the world into two opposing camps. Over twenty open letters and circulars were written by the Cuban bishops from January 1959 through February 1961, attempting to encourage the revolutionary leaders to adopt an autochthonous Cuban and Catholic form of humanistic socialism rather than a fully communist affiliation with the Soviet bloc. The progressive Catholic magazine La Quincena, gave unwavering support for Castro. ${ }^{68}$

Despite expressions of concern when executions of Batista officers began in January 1959, the initial enthusiasm of Catholic support for Castro and the revolution was not dimmed. In early February, Archbishop Pérez Serantes urged Castro to "temper

an enthusiastic statement about the possibility of agrarian reform, "according to Catholic social doctrine." La Quincena, Feburary 1959, 20, 30 and 46.

${ }^{65}$ Obispos Católicos de Cuba, La Voz de la Iglesia," 53.

${ }^{66}$ Ibid., 53; Fernández Santalices, Cuba, 61-62; La Quincena, January, 1959, 3.

${ }^{67}$ La Quincena, February, 1959, 20. 
revolutionary justice with mercy" although the Archbishop hastened to affirm that the executions "have not exceeded, nor yet equaled, in harshness those issued in other places. ${ }^{\prime 69}$ Despite the reprisals against suspected Batista supporters, the church remained hopeful.

The February 1959 issue of La Quincena carried an article focusing favorably on the "pensamiento social" (social thinking) of Fidel. The article was critical of the Cuban Communist Party, but referred favorably to the leaders of the 26th of July Movement and Castro. On the same page, there was a note discussing the "artimañas" (manipulations) of the Cuban Communist Party to infiltrate and take over workers syndicates, specifically the CTC, Confederación de Trabajadores de Cuba (Confederation of Cuban Workers). The article spoke in glowing terms of "Revolución Triunfante" (Triumphant Revolution) while at the same time being severely critical of communism. The author expressed mild caution about the danger that the public would cast Castro in the role of caudillo (strong man or political boss). ${ }^{70}$

An article in La Quincena about the Cuban JOC affirmed that the Juventud Obrera Católica had maintained opposition to Batista and had demonstrated beyond any doubt their firm commitment to the revolution. The article added that nearly eight thousand young Catholic workers had gathered in the Plaza de la Catedral in a rally to greet their leaders who had returned home from exile. ${ }^{71}$ The May issue of La Quincena included a

\footnotetext{
${ }^{68}$ Obispos Católicos de Cuba, La Voz de la Iglesia, 53; La Quincena, January, 1959.

${ }^{69}$ New York Times, February 2, 1959.

${ }^{70}$ La Quincena, February, 1959, 17-20.

${ }^{71}$ La Quincena, February 1959: 47.
} 
call from the Young Catholic Workers (JOC) for unity in support of the revolutionary measures and firm opposition to all counterrevolutionary activity, along with an historical essay reviewing Christian 'communitarian' movements in history. ${ }^{72}$

In a speech in Havana just prior to visiting the United States in April, Castro called for rapid implementation of education and health care reforms before elections were held. In a meeting with U.S. Vice President Richard Nixon, Castro claimed that he was not a communist and was not in agreement with communism. ${ }^{73}$ Nevertheless, despite Castro's assurances of moderation, the Agrarian Reform Law was implemented in May and represented the strongest social reform measure to date. Land ownership was limited to 1,000 acres, with a few exceptions. Larger holdings were nationalized, and reorganized into state cooperatives, or broken up and given to small farmers. The Agrarian Reform Institute (INRA) was established. ${ }^{74}$ Auxiliary bishop of Havana, Evelio Diaz, issued a circular letter, "The Catholic Church and the New Cuba" on May 31 that endorsed the Agrarian Reform Law as "fundamentally aligned with the Church's thinking on the principles of social justice." 75

In the summer of 1959, the first cracks in the apparent Catholic-revolutionary unity began to surface publicly around the issue of the agrarian reform. ${ }^{76}$ The magazine Bo-

${ }^{72}$ La Quincena, May 1959, 27, 36.

${ }^{73}$ Tad Szulc, Fidel: A Critical Portrait (William Morrow \& Company 1986), 488-489.

${ }^{74}$ Pérez, Cuba, 322.

${ }^{75}$ Obispos Católicos de Cuba, La Voz de la Iglesia, 79. Authors Translation from the Spanish, "La Iglesia Catolica y la Nueva Cuba: 'La Reforma Agraria ... se ajusta fundamentalmente al pensamiento de la Iglesia en cuanto a su principio de Justicia Social." 
hemia published one of the last supportive letters from a member of the Catholic hierarchy on July 5, regarding the Agrarian Reform. Using language that prefigured postVatican II Catholicism's liberationist discourse of a decade later, Bishop Alberto Martín Villaverde of Matanzas, wrote of the need for the Cuban government to exercise a special "preference" on behalf of the rural peasants in its implementation of agrarian reform. Appealing to Pope Leo XIII's (1878-1903) teaching on social justice, Monseñor Villaverde called for reform that gave special attention to remedying the plight of the neediest $\mathrm{Cu}$ bans, while qualifying his disagreement with collectivization of land by the State. The bishop did not hesitate to call the unequal distribution of property and wealth in Cuba to be a "grave evil" and called for energetic remedies for social justice. ${ }^{77}$ Pérez Serantes, after issuing an endorsement of the agrarian reform the previous week, clarified his earlier support by expressing concern that the authors of the agrarian law and the communists "drank from the same fountain" and warned Castro that such orientation would not help the revolution. Serantes further called on Castro to carry out the agrarian reform in harmony with interested parties. ${ }^{78}$

In August 1959, the tension gradually increased in both the domestic and the international spheres after the resignation of President Manuel Urrutia Lleó $(1901$ - 1981) and his replacement with Castro loyalist, Oswaldo Dorticós. Nevertheless, an uneasy

${ }^{76}$ On June 29, 1959, Pope John XXIII issued the first of eight papal encyclical letters, Ad Petri Cathedram in which he addressed the issue of class conflict and, speaking in particular to young people, also affirmed the strategic role of Catholic Action as "a peaceful militia" that was needed to augment the labors of priests and religious in the apostolate of the hierarchy (115). He called upon the militants of Catholic Action to "marshal their ranks and shirk no hardship, shun no inconvenience that the cause of the Church may be triumphant.” (121) Osservatore Romano, July 3, 1959.

${ }^{77}$ Obispos Católicos de Cuba, La Voz de la Iglesia, 87. 
truce continued between the Cuban Catholic Church and the revolutionary government. The Apostolic Nuncio, Monseñor Luis Cenni, and the Cuban minister of education, Dr. Armando Hart participated cordially together in the XV National Congress of Cuban Catholic Schools which represented 259 Catholic schools in Cuba. ${ }^{79}$ Meanwhile, there was mounting concern in the Caribbean and among members of the Organization of American States regarding the ideological direction that the Cuban Revolution was taking. Chile still had not heard from Cuba regarding Cuba's participation in the OAS meeting scheduled for the same month. There was insurrectionary conflict in Nicaragua, disturbances in Venezuela between President Betancourt and the communist party in addition to rising tensions among Venezuela, Cuba and the Dominican Republic. ${ }^{80}$ Meanwhile acts of sabotage and guerilla resistance began. On August 9, shots were fired at Castro's home in Cojimar, although he was not at home. ${ }^{81}$ Rather than attending the OAS meeting in Chile, Castro unexpectedly appeared in Cienfuegos to deal personally with a counterrevolutionary incursion backed by Rafael Trujillo from the Dominican Republic. ${ }^{82}$ Fidel and his personal body guards were waiting when an airplane from the Dominican Republic landed and he personally arrested the ten Cubans on board. ${ }^{83}$ Meanwhile, at the

\footnotetext{
${ }^{78}$ New York Times, July 17, 1959.

79 “Varios países piden a Cuba que asista a la reunión de Chile,” Diario de la Marina, August 2, 1959.

${ }^{80}$ Diario de la Marina, August 6, 1959.

81 “Tiroteada anoche la casa del Dr. Castro situada en Cojimar,” Diario de la Marina, August 9 , 1959.

82 "Inesperadamente Fidel Castro llegó a Cienfuegos, de donde partió con rumbo desconocido" Diario de la Marina, August 13, 1959; "La situazione a Cuba” Osservatore romano, August 12, 1959.

${ }^{83}$ Tad Szulc, Fidel, 551.
} 
meeting of the OAS there was a violent altercation between representatives of Cuba and those of the Dominican Republic. As the U.S. Secretary of State, Christian Herter (18951966) was denouncing the threat of communism, the Cuban Minister of State, Raul Roa, was physically threatened. ${ }^{84}$ During this time ambiguity over the Cuban revolutionary government's position on communism continued. The Brazilian ambassador to Cuba has defended the revolutionary government maintaining that Castro was not communist. In early September, on a return trip from Spain, even Che Guevara asserted that revolutionary regime not communist. ${ }^{85}$

On September 1959, the front page of the conservative Catholic newspaper, Diario de la Marina, assured the world that Fidel, although radical, was neither a communist nor a capitalist, and that the Cuban Revolution was not a turn to the right or the left, nor was it remaining in the center. Rather it represented a step forward and represented a third way - a humanist revolution. The author affirmed that the Cuban Revolution was more radical than many expected, but that it remained as "Cuban as the palm trees" quoting a phrase from Castro. The author believed that the Cuban people would not tolerate totalitarianism, nor would they embrace a form of revolution contrary to "Christian values." ${ }^{86}$ There was nothing to fear from the Cuban Revolution as long as it stayed within the boundaries of the Constitution of 1940. Two days later, another editorial in the same

84 “La situazione a Cuba" Osservatore romano, August 12, 1959.

85 “'Ni Castro, ni el Gobierno de Cuba son comunistas' Declaró el Embajador del Brasil L. de Cunha", Diario de la Marina, September 1, 1959; "Ernesto Guevara 'no somos comunistas,"” Diario de la Marina, September 7, 1959.

86 “Revolucion, Religion, Economia”, Diario de la Marina, September 6, 1959. 
newspaper said that "In the case of the Cuban Revolution, the Catholic Church supports without vacillation the struggle for the improvement of the life-style of the people, the Agrarian Reform, honest administration, and healthy and appropriate nationalism. ${ }^{87}$ Further editorials carried selections from the Vatican newspaper on the fundamental incompatibility between Marxism and democracy. ${ }^{88}$ As the Cuban Church responded to the growing threat of Soviet-style Marxism, traditional Catholic reservations toward democracy, individualism and free enterprise were conveniently subordinated and appeals to democracy and free enterprise were now incorporated into Catholic ideological discourse and counterpoised against Marxism as a political philosophy.

On September 27, the International executive committee of the Young Christian Workers (JOC) branch of Catholic Action met privately in Havana. The decision to meet in Havana sought to recognize the historic nature of the Cuban Revolution. As a Catholic lay organization representing young workers, JOC often tended to be a more progressive wing of international Catholicism. Among the countries represented by the committee members were Canada, Chile, France, Belgium, Germany, Spain, the Philippines, and Brazil. Monsignor Joseph Cardijn, founder of the JOC, attended the meeting in Havana and later met with President Dórticos. The conference ended with a special event on Saturday night, October 3, with Cardijn as the speaker. ${ }^{89}$

\footnotetext{
${ }^{87}$ Diario de la Marina, September 8, 1959.

${ }^{88}$ Diario de la Marina, September 11, 1959.

${ }^{89}$ Diario de la Marina, September 13, 1959; Diario de la Marina, October 1, and October 4,
} 1959. 
Crisis and Confrontation between Church and State, 1959-1962

In October of 1959, the façade of goodwill and harmony between the Catholic Church and the revolutionary regime under Castro began to rapidly dissolve. The revolutionary government was successfully taking control of most mass organizations in Cuba including the student organizations in the University of Havana such as university student organization, the FEU (Federación Estudiantil Universitaria). In the fall of 1959 a civilian militia was created which grew from one hundred thousand volunteer members to over three hundred thousand members by $1961 .{ }^{90}$ September through October of 1959 there was a significant turning point for the revolutionary process. Castro began to be aware of stiffening resistance to the revolution among middle class liberals and members of the clergy, especially to the ongoing agrarian reform program. Che Guevara observed that what had been intended as a bourgeois agrarian reform became a violent struggle. In order to advance any further, a decisive break with both the Cuban Catholic Church and the United States was apparently unavoidable. ${ }^{91}$ In October, Castro began to criticize the elite conservative Catholic-oriented newspaper, Diario de la Marina. The editor, José Rivero, responded with a front page insert cautiously affirming the newspaper's commitment to "freedom of expression.","92

The following Saturday, Diario de la Marina published the call of the Cuban bishops to hold a National Catholic Congress for the end of November. The article said

\footnotetext{
${ }^{90}$ Pérez, Cuba, 330.

${ }^{91}$ Ibid., 323.

${ }^{92}$ Diario de la Marina, October 1 and 2, 1959.
} 
that the primary theme would be social justice. Perhaps as a sign of the general feeling of threat within Latin American Catholicism, the Canadian Catholic Conference voted to form an organization for the defense of Catholicism in Latin America. ${ }^{93}$ Monsignor Eduardo Boza Masvidal, assistant bishop of Havana and director of the University of Villanueva, declared that Roman Catholics in Cuba cannot "support the tendencies toward a materialistic communism and totalitarianism in the Cuban Revolution." ${ }^{.94}$

In a circular letter published in November, Monsignor Pérez Serantes spoke about a large mobilization of Catholic faithful in the Civic Plaza at the Catholic National Congress, scheduled for the end of the month. Pérez Serantes, anticipated the participation of "hundreds of thousands" of Cubans in public worship. ${ }^{95}$ A similar circular letter, written by Bishop Martín Villaverde of Matanzas who in July had been supportive of the Agrarian Reform and had spoken in liberationist language, now warned of those who attempt to uproot the idea of God among men through stirring class and racial tensions and through removing God from education. Villaverde presented a starkly Manichean scenario of conflict between the philosophy of materialism and the philosophy of the kingdom of God. In his view, the philosophy of materialism would result in hatred but the philosophy of the kingdom of God would result in love. He called upon the Cuban people to choose between these two philosophies, and warned them that it would be suicide for the people to choose to deny God. He declared that the purpose for the Congress was to announce to

${ }^{93}$ Diario de la Marina, October 3, 9 and 15, 1959.

${ }^{94}$ New York Times, October 31, 1959.

${ }^{95}$ Obispos Católicos de Cuba, La Voz de la Iglesia, 88. 
the world that Cubans had made their choice between the two options. According to Villaverde, the Cuban people, as represented by the Congress, "wanted love and a homeland, they did not want God to be uprooted and disunity and hatred to be sown in his place." ${ }^{96}$

The National Catholic Congress represented the climax of an ideological battle between Castro and the Catholic Church. The bishops were utilizing the congress as a form of symbolic mass communication to try to make the case that Cuba was a homogeneously "Catholic" nation, and that Catholicism ought to provide the guiding ethical and moral values for the implementation of the reforms of the revolution. The battle for control of public symbols was particularly focused on the Virgin of Charity, long a symbol of Cuban nationalism. Castro spoke to a rally of students gathered at Havana University where placards saying "down with the Catholic Congress" were abundantly evident. He accused the Congress of being a facade for attacks on the Cuban Revolution. ${ }^{97}$

Some reports estimated that nearly a million Catholics participated in the processions and activities of the Congress. Castro himself attended the Congress, arriving just before the beginning of the mass and kissing his mother and two sisters before sitting down behind them. He was accompanied by President Dorticós and several Cabinet members. Eighty-year-old Cardinal Manuel Arteaga arrived shortly before the statue of the Virgin was brought into the plaza. Following the mass, Pope John XXIII administered a papal blessing in Spanish via radio from the Vatican. The Pope appealed for an atmos-

\footnotetext{
${ }^{96}$ Obispos Católicos de Cuba, La Voz de la Iglesia, 92. Translated from the Spanish by the author: "Y por eso se ha reunido en este grandioso Congreso para decirle al mundo que ya hemos escogido: que tenemos Padre, que tenemos Madre; que queremos amor, que queremos patria; que no queremos a los que arrancan a Dios siembran la desunión y el odio."

${ }^{97}$ New York Times, November 28, 1959.
} 
phere of peace and charity. The final session erupted in shouts of "Down with Communism" by thousands who crowded the Stadium. Dr. Jose Ignacio Lazaga, a leader of the Catholic Youth Movement, told the throng: "we believe that Catholic thinking on this subject can be summed up in this phrase: 'totalitarian states, no: social justice, yes.",98

The Cuban Catholic hierarchy may have drawn the mistaken conclusion from the large turn-out that the Catholic Church enjoyed more popular support than was actually the case. Archbishop Pérez Serantes issued another pastoral letter on December 24 in which he summarized lessons drawn from the massive mobilization of Catholic faithful at the National Congress at the end of November. On the basis of the high level of participation in the Congress, Pérez Serantes concluded that Cuban people were a "Catholic people in the immense majority" and that it would be a grave error for the government to treat the Catholic Church as just another religious denomination in Cuba. ${ }^{99}$ Pérez Serantes unequivocally demanded: "We want a Catholic Cuba (Queremos Cuba católica). ${ }^{100}$ Nevertheless, it is likely that the attendance at the National Congress reflected underlying political anxiety of the middle class about the direction of the revolution rather than a true measure of popular support of Cuban Catholicism. Coinciding with Pérez Serantes' letter, a statement by Pope John XXIII acknowledged that the church was ideologically opposed to communism despite its desire for peace. ${ }^{101}$

${ }^{98}$ R. Hart Phillips, “Cuban Catholics Counter Red Aim,” New York Times, November 29, 1959.

99 “Después Del Congreso Católico Nacional: Lecciones del Congreso," Obispos Católicos de Cuba, La Voz de la Iglesia," 98.

${ }^{100}$ Ibid.

101 "Pide S.S. Papa no confunden la paz que quiere la Iglesia con una concesión a ideologías opuestas." Diario de la Marina, December 23, 1959. 
In early 1960, the conflict between Revolutionary leaders and the Church hierarchy intensified as Castro and his revolutionary supporters reacted to the momentum generated in the National Catholic Congress of late November and the hierarchy's attempts to mobilize Catholics to resist the government's revolutionary agenda. On January 20, Castro severely criticized religious orders such as the Sacred Heart, the Dominicans and upper-class clergy and distinguished them from working-class clergy. In his view, the clerical elite were ambitious, egotistical, retrograde and predatory; the lower class clergy were humble, charitable, hardworking and the victims of the exploitation of the elite. ${ }^{102}$

The ideological clash between Cuban Catholicism and the Revolution was most intense among the young. The Catholic Church had been working for years to mobilize and indoctrinate young workers and university students through lay orders such as the Young Catholic Workers (JOC), the Young Catholic Students (JEC), the Young Catholic University Students (JUC) and the Agrupación Católica Universitaria (ACU). The Revolutionary junta countered by organizing the IV Congress of Socialist Youth in Havana in April 1960. In the closing ceremonies, Juan Marinello, president of the communist party and Rector of the University of Havana, declared that Catholics had nothing to fear from the Cuban communist party as long as they stayed inside their temples adorning their images, but if they come out of their temples to make counterrevolution, the communists would face them in struggle. Diario de la Marina ran a front page article criticizing rep-

\footnotetext{
${ }^{102}$ Directorio Revolucionario Estudiantil de Cuba, La Persecución de la Iglesia Católica en Cuba, Quito, Ecuador [no date] 6.
} 
resentatives of the July 26 Movement for their participation in the Congress and lamenting the communist efforts to influence the youth of Cuba. ${ }^{103}$

Another editorial in the Diario de la Marina on April 1, 1960, firmly asserted that Catholicism was the only force of universal influence able to resist the forces of evil that wanted to destroy Christian culture. The editorial concluded with a call to Catholics to join the priestly legions under the Pope to utilize the superior arms of the church to defeat Soviet totalitarianism. ${ }^{104}$ There was a notable increase in the shrill discourse of violent confrontation by the conservative elites using symbolic martial imagery. Despite the intensifying ideological clash, the Castro regime attempted to maintain correct diplomatic relations with the Vatican. The new Cuban ambassador to the Vatican, Dr. José Luis Velasco, presented his credentials to the Pope in early April. ${ }^{105}$

In May 1960, Pérez Serantes issued a tense pastoral letter in which he urgently warned that the "Enemy is within" (El enemigo está dentro) and asserted that the battlelines were now clearly drawn between the Church and her enemies. ${ }^{106}$ Pérez Serantes went on in the same pastoral letter to firmly attack communism and to call Cuban Catholics to adopt an attitude of total resistance to the revolutionary government's Marxist program: "With Communism, nothing, absolutely nothing. Given the repeated condemnations, from the highest authority of Catholicism, we feel the urgent need to recommend and even admonish our diocesan (and if possible to all Cubans) do not want in any way

${ }^{103}$ Ibid., 7; Diario de la Marina, April 1, 1960. The Cuban Communist party was called the Partido Socialista Popular (PSP), founded in 1925, and renamed in 1944.

104 “Roma y la lucha contra el totalitarismo," Diario de la Marina, April 1, 1960, 4.

${ }^{105}$ Diario de la Marina, April 5, 1960, 11. 
cooperate with communism, or go along arm-in-arm with the same." ${ }^{107}$ Pérez Serantes made an ideological statement, typical of traditional Catholicism and in clear contrast to John XXIII, who early in his papacy mildly observed that the church did not have enemies. ${ }^{108}$ In the eyes of the revolutionary government, it was also counterrevolution.

Serious divisions began to appear between progressive and conservative Catholics. Diario de la Marina attacked La Quincena for its apparent sympathy with the Cuban Revolution. La Quincena responded by dismissing Diario de la Marina for being a typically conservative, classist newspaper, which, in the editorial's words, "says it all" (y con eso ya está dicho casi todo). According to the progressive Catholics represented in $L a$ Quincena, the task of Christians in Cuba should be to strengthen those Christian elements latent within the revolution. The authors affirmed that Cubans should recognize that the Cuban Revolution was the first revolution that was inspired by Christian motives. Within a few weeks, the government finally acted to silence the conservative "counterrevolutionary" voice of the Diario de la Marina by occupying its offices and closing it down along with another conservative newspaper, La Prensa Libre. ${ }^{109}$

The first physically violent conflict between supporters of the 26th of July Movement and representatives of the Catholic Church took place on July 17, at a mass in

106 “El enemigo está dentro,” Obispos Católicos de Cuba, La Voz de la Iglesia, 105.

107 “Por Dios y Por Cuba,” La Voz de la Iglesia, 107, 109. Translation from Spanish by author: "Con el Comunismo, nada, absolutamente nada. Ante las repetidas condenaciones, procedentes de la autoridad suma del Catolicismo, nos vemos en la imperiosa necesidad de recomendar y aun de conminar a nuestros diocesanos (y si cabe a todos los cubanos) no quieran en manera alguna cooperar con el comunismo, o ir del brazo con el mismo."

${ }^{108}$ Christian Feldman, Pope John XXIII, A Spiritual Biography, (New York: The Crossroad Publishing Company, 2000), 122. 
front of the Cathedral of Havana in which Auxiliary Bishop Eduardo Boza Masvidal criticized communist persecution against Catholics. The following day there was another incident resulting in the wounding of several people including a priest. Monsignor Boza was publically attacked for his anti-communist sermon by Radio Mambí and Castro went on television and drew attention to the high number of clergy of Spanish origin serving in Cuba and called them "Falangists" referring to Spanish Francoist fascism. ${ }^{110}$

In August 1960, the Church hierarchy threatened to suspend services in the churches, unless there was a guarantee of freedom of worship from Castro's Regime. Monsignor Evelio Dias, Coadjutor Archbishop of Havana and the second highest church official in Cuba, visited the Presidential Palace and spoke with Dr. Luis Buch, Secretary to the Presidency. It was reported that he discussed the failure of the authorities to Cuba to protect worshippers from communist elements and asked for guarantees for the holding of Catholic Youth Congress scheduled here August 23 and $24 .{ }^{111}$ Immediately following, Cardinal Arteaga and eight archbishops of the Church of Cuba signed a collective pastoral letter roundly condemning the advance of communism and growing ties between $\mathrm{Cu}-$ ba and the Soviet Union. For the first time, the Catholic Church of Cuba issued an officeal condemnation against the increasing communistic tendencies of the Castro regime. The letter indicated a clash of competing ideologies by stating the impossibility of any form of collaboration between Catholics and communists, "Catholicism and Communism

\footnotetext{
109 “El Caso Del "Diario De La Marina” La Quincena, May/June 1960, 32; "Los Cristianos y la Revolución,” La Quincena, May/June 1960, 57; Pérez, Cuba, 324.

110 "Spain says Castro lied about priests," New York Times, August 8, 1960; Directorio Revolutionario, Persecución de la Iglesia: 7-8.

111 “Cuban Archbishop Threatens To End Church Services,” New York Times, August 9, 1960.
} 
respond to two totally opposed conceptions of man and the world and will never be reconciled."112 The lines of ideological opposition were clearly drawn in the sand between the Castro Regime and the hierarchy of the Cuban Catholic Church.

In the days following the release of the collective pastoral letter, a number of violent and semi-violent clashes took place between supporters of the Revolution and the Catholic hierarchy. August 9 1960, a mob surrounded the Cathedral of Havana and prevented Monsignor Boza and several assistants from leaving. When the police arrived, two priests were arrested but no members of the mob were detained. The following day, in an address to the Workers Central Union of Cuba, the CTC (Confederacion de Trabajadores de $C u b a$ ), Castro accused Catholic priests of being Francoists, Fascists, Falangists, reactionaries, foreigners, and criminal and exploitive associations. ${ }^{113}$ On August 13, a collective letter signed by all the Catholic organizations proclaimed their support for the Catholic hierarchy. Although many priests were roughed up, intimidated or interrogated and generally mistreated, the Castro regime was very careful not to create martyrs. Within the month, the Castro regime began to create the Committees for the Defense of the Revolution (CDRs). ${ }^{114}$

On August 12, Castro denounced the hierarchy of the Roman Catholic Church in Cuba for what he called "systematic provocations" against his government. He charged

\footnotetext{
${ }^{112}$. R. Hart Phillips. "Catholic Church In Cuba Criticizes Communist Gains," New York Times, August 8, 1960; “Circular Colectiva del Espiscopado Cubano," La Voz de la Iglesia, 116-117. Author's translation from Spanish: "porque el Catolicismo y el Comunismo responde a dos concepciones del hombre y del mundo totalmente opuestas que jamás será posible conciliar."

113 The CTC was the main Trade Union in Cuba.

${ }^{114}$ Directorio Revolutionario, Persecución de la Iglesia, 10, 11; Pérez, Cuba, 330.
} 
that the provocations had been instigated by the U.S. Embassy and Francisco Franco. Addressing a workers rally, Castro declared: "Those who condemn it (the Cuban revolution) condemn Christ, and they would be capable of crucifying Christ because He did what we are doing." Castro charged that the church's "provocations" were the work of "scribes and Pharisees who are serving U.S. imperialism and its partner, Franco. ${ }^{115}$ The Premier made a distinction between the church hierarchy and the "revolutionary priests" in Cuba. Castro was obviously highly irritated by the pastoral letter read Sunday in which the Church expressed its concern with the rise of communism in Cuba and the close relations between Cuba and the Soviet Union. There were said to be 500 Spanish priests among the 800 clergy serving in Cuba. Castro declared that he would like to see archbishops condemning the "crimes and murders of Franco" in addition to the "crimes and horrors of United States imperialism." ${ }^{, 16}$ By September 18, all Catholic radio and television programs had been closed down.

In November the ideological conflict intensified in the academy. A ceremony of swearing loyalty by professionals to the principles of the Revolution occurred at the University of Havana. Rolando Cubela, the head of the FEU (Federación de Estudiantes Universitarios), accused Monsignor Eduardo Boza Masvidal of being a counterrevolutionary. ${ }^{117}$ Pérez Serantes responded in early December with a pastoral letter titled "Rome or Moscow" in which he attacked communism as a "moral virus" that infected a

\footnotetext{
gust $12,1960$.

${ }^{115}$ R. Hart Phillips, "Castro Accuses the Catholic Church of 'Provocation," New York Times, Au${ }^{116}$ Ibid.

${ }^{117}$ Directorio Revolutionario, Persecución de la Iglesia, 12.
} 
society and led it to the extreme danger of ruin. The letter attacked the concept of lay education and divorce in which the family was damaged and children were misled from religion. Pérez Serantes praised the humanist-Christian ideology of the United States which he attributed to the religious orientation (especially Catholic) which had been allowed to flourish. He went on to assert that if the United States were to neglect its Christian orientation, it would not be able to resist Soviet Communism and said that the real battle is not between Moscow and Washington, but rather Moscow and Rome. The Archbishop waxed eloquent, almost poetic, as he closed his pastoral letter calling upon the "soldiers of Christ" and "members of the invincible hosts" to take their place alongside their great Captain (Christ) who outshines Alexander the Great, Hannibal, Julius Caesar, and Napoleon, in clearly imperial language. The teachings of Christ regarding meekness, peacemaking, forgiveness, and loving one's enemies was passed over without mention. ${ }^{118}$

Castro countered on December 16 in an address to the CTC by affirming that to be anti-communist was indeed to be a counterrevolutionary. ${ }^{119}$ The hierarchy quickly responded with an open letter to the "Prime Minister, Dr. Fidel Castro" protesting the closing of Catholic newspapers and radio and television programs, and defending themselves from Castro's accusations that the clergy were counterrevolutionaries. ${ }^{120}$ The letter was signed by nine members of the Cuban hierarchy including Cardinal Arteaga, two

\footnotetext{
118 “Roma o Moscu," La Voz de la Iglesia, 135-140.

${ }^{119}$ Directorio Revolutionario, Persecución de la Iglesia, 14.

120 “Carta Abierta del Episcopado al Primer Ministro Dr. Fidel Castro," La Voz de la Iglesia”: 146.
} 
archbishops and the other bishops. ${ }^{121}$ The Archbishop of Santiago, the most prolific of the writers of the clerical letters, published yet two more pastoral letters to close out December: one in which he responded to Castro's criticism in September of the failure of the Church to condemn the crimes of Franco or the United States, and the other in which he implied the opposing loyalties and ideologies of the Church and the revolutionary government: "The Church takes its stand under the banner of Christ; the communists, under that of Marx. It is not the Church that has sought out an enemy.",122

As 1961 opened and a new Catholic president took office in the United States, the revolutionary regime was aware through its security services that plans were afoot for a possible invasion organized by the CIA. The Cuban government had been in the process of seeking military assistance from the Soviet Union as protection from an attack from the United States. ${ }^{123}$ One must interpret Castro's conflicts with the Catholic hierarchy in the larger context of deteriorating relations with the United States and contingency plans being developed in Washington as early as March 1960 under President Dwight Eisenhower for an invasion of Cuba or an assassination of Castro. These plans accelerated with Castro's legalization of the Communist party and expulsion of most of the personnel in the American embassy in January 1961. In the early days of the Kennedy administration

${ }^{121}$ Ibid., 150.

122 "With Christ or Against Christ," La Voz de la Iglesia, 151 and 160. Author's translation from the Spanish: "La Iglesia enarbola la bandera de Cristo; los communistas, la de Marx. Como se puede ver, no es la Iglesia la que ha ido a buscar a su enemigo."

123 “Guevara a Moscu," Diario las Americas. October 6, 1960. 
at least one CIA attempt, and possibly two, was made on Castro's life. The CIA plan involved the recruitment of Sam Giancana, the head of the Chicago Mafia. ${ }^{124}$

It was in a tense and uncertain situation, with the pretext of a possible invasion, in which revolutionary militants took over Catholic seminaries, several churches, and Catholic educational centers in all of Cuba in early $1961 .{ }^{125}$ Even leaders of the JOC were arrested at their headquarters. ${ }^{126}$ Pérez Serrantes published yet another pastoral letter titled "Respect and Justice" protesting the arrests and the actions of the government. ${ }^{127}$ On January 23, Fidel Castro called the pastoral leaders, "thugs wearing clerical collars" and complained that they were handing over an ideological weapon to the "assassin hands of counterrevolutionaries." ${ }^{128}$ The final pastoral letter was written on February 11 in which the Archbishop defended himself against charges that he was a counterrevolutionary and the pastor of conspirators. There would be no more pastoral letters issued by the clergy in Cuba until 1969. ${ }^{129}$

Harassment of the Church by revolutionary militias and mobs continued in April with disruptions during Holy Week celebrations as the revolutionary government and Catholics fought over symbolic public space. With the Bay of Pigs invasion of April 17,

\footnotetext{
${ }^{124}$ Mark J. White, Missiles in Cuba, Kennedy, Khrushchev, Castro and the 1962 Crisis, (Chicago: Ivan R. Dee, 1997), 5, 16, 27.

${ }^{125}$ Directorio Revolutionario, Persecución de la Iglesia: 14.

${ }^{126}$ Ibid.

127 “Respeto y Justicia," La Voz de la Iglesia”: 167.

${ }^{128}$ The ACU (ACU was the oldest university movement in Cuba under the direction of the Jesuits). Directorio Revolutionario, Persecución de la Iglesia: 15.

129 “To our faithful priests," La Voz de la Iglesia," 171.
} 
1961, the government finally launched a direct frontal assault against the Church hierarchy. Churches were closed, priests and bishops were detained. By some estimates across the whole island there were nearly a hundred thousand detentions, hundreds of executions by firing squad and several thousand people taken as political prisoners. Among those arrested in Havana were Boza Masvidal and Evelio Diaz. Several students who belonged to the ACU were summarily shot. ${ }^{130}$ On May 1, 1961, Castro announced the nationalization of all of the private schools and the expulsion of all foreign priests. Expulsions of religious orders and foreign priests began in May with expulsion of North American Augustinian priests and continued in June in Matanzas and soon included Jesuits, Carmelites and other orders. ${ }^{131}$

This was a period of great agitation and conflict between the Catholic Church and several Caribbean and Central American governments including Haiti, Panama and Nicaragua as well as the Dominican Republic and Cuba. ${ }^{132}$ Rafael Trujillo, the dictator of the Dominican Republic was assassinated in June. In Cuba, the assault against any vestiges of Catholic resistance continued in July with the detention of Castro's former friend, Archbishop Pérez Serantes for over a week along with over one hundred other priests. ${ }^{133}$

\footnotetext{
${ }^{130}$ Directorio Revolutionario, Persecución de la Iglesia, 20-21; Pérez, Cuba, 331-32.

131 "Expulsión en Masa de Sacerdotes y la Confiscación de Las Escuelas Privadas Anunció Fidel Castro Ruz," Diario las Américas, May 3, 1961; “Diez y Ocho Agustinos Expulsados de Cuba," Diario las Américas, May 5, 1961; “Trescientos Sacerdotes y Monjas Saldrán en un Barco de La Habana. Posible Ruptura de Brasil Con Cuba,” Diario las Américas, May 9, 1961.

132 "Partidos Demócratas-Cristianos Condenan a Cuba, Nicaragua, S. Domingo, Haiti y Paraguay," Diario las Américas, May 25, 1961; "Matan A Trujillo," Diario las Américas, June 3, 1961; "Golpean a Monjas Hasta Hacerlas Sangrar en República Dominicana," Diario las Américas, June 3, 1961; "Llegan 45 Monjas de Puerto Rico a Miami," Diario las Américas. June 7, 1961.
} 
The conflict between the Revolutionary government and the Catholic hierarchy came to a final climax in September as the festival of la Virgen de la Caridad del Cobre approached. The government prohibited all of the traditional religious ceremonies. Nevertheless, auxiliary bishop Eduardo Boza Masvidal sought permission for a procession several days later, on September 10. As the four thousand Catholics who had gathered for the procession were about to begin, word came that the permission had been rescinded. In the confusion, government soldiers opened fire on the crowd and a member of the Young Catholic Workers (JOC) was killed. Within this tense and violent atmosphere that 135 priests, including bishop Boza were rounded up and summarily deported on September 13. Although the majority was foreign priests, 46 were Cubans. ${ }^{134}$ Fidel Castro proclaimed himself a Marxist-Leninist in November and on December 1, 1961, Castro declared that the political ideology of the revolution would be Marxist-Leninist and would no longer be a secret. ${ }^{135}$

The ideological clash between Cuban Catholicism and Castro was over. The majority of the Church hierarchy was expelled, the Castro regime was in full control and millions of Cubans had been mobilized in support of the revolution. Thereafter, Cuban Revolution would fully embrace Soviet communist ideology. The public symbols of the church and of the nation had been expropriated and re-worked on behalf of a secular

133 “Obispo y 116 Sacerdotes Estuvieron Presos Una Semana en Una Iglesia de Camagüey, Pérez Serantes," Diario las Americas, July 15, 1961, 6.

134 "Castro vs. the Virgin," Time (on-line), September 22, 1961; "Tropas de Castro Ametrallan al Pueblo Católico en la Habana: Gobierno Prohibió la Procesión de la Virgen de la Caridad del Cobre," Diario las Américas, September 12, 1961; "Castro Expulsa a un Obispo y a 135 Sacerdotes," Diario las Américas, September 19, 1961. 
Marxist-Leninist ideology and would remain so until the visit of Pope John Paul II to Cuba thirty-seven years later, in $1998 .^{136}$

Traditional Catholicism prior to the Second Vatican Council maintained an integrated ideology of social and political hegemony that rested on the foundations of Iberian Christendom. While espousing concern for the poor through its social teaching, Catholicism continued to depend on an alliance with elites to maintain its place in society. Unlike countries with institutionally strong Catholic Churches, such as Colombia or Spain, the Cuban Catholic Church was institutionally weak and only had limited influence with the Cuban poor and popular classes, both urban and rural. Nevertheless, threatened by a competing ideology that effectively mobilized the popular classes, the church overestimated its own strength and attempted to oppose Castro's consolidation of power by contesting the symbolic public space and the use of mass communications. ${ }^{137}$ The Catholic Church's endemic involvement in the ideological political strife in the twentieth century culminated in the defeat of conservative Catholic ideology in Cuba in the early 1960s. ${ }^{138}$

\footnotetext{
${ }^{135}$ Pérez, Cuba, 332; Tad Szulc, Fidel: A Critical Portrait (William Morrow \& Company 1986), 568.

136 “A Populist Pope, crowds break out into Papal Fiestas.” Miami Herald, January 24, 1998.

${ }^{137}$ John Thompson focuses on the key role of symbolic transmissions of mass communications as part of the dissemination of ideology. Ideology for Thompson thus involves the mobilization of meaning in symbolic forms to sustain domination and to serve the interest of ruling elites. John Thompson, Studies in the Theory of Ideology (Berkeley: University of California Press, 1984).

${ }^{138}$ Catholicism has been made to serve as an elite ideology in Brazil, where it was called "neoChristendom" (Serbin) and in nineteenth century Mexico, where it legitimated Mexican conservatism (Knight), in nineteenth-century Spain, where it manifested as mobilizing ideology for conservative Spanish nationalism (Junco); and in twentieth-century Spain under Franco, where it served as a gender-oriented Catholic nationalism (Morcillo). See Kenneth P. Serbin, "Church-State Reciprocity in Contemporary Brazil: The Convening of the International Eucharistic Congress of 1955 in Rio de Janeiro," The Hispanic American Historical Review 76.4 (Nov 1996): 726; Alan Knight, "The Peculiarities of Mexican History: Mexico Compared to Latin America, 1821-1992," Quincentenary Supplement: The Colonial and Post Colonial Experience. Five Centuries of Spanish and Portuguese America, Journal of Latin American
} 
Less than a year after Castro's ideological triumph over the Cuban Catholic Church, in the midst of the superpower confrontation precipitated by the Cuban Missile Crisis, the Second Vatican Council opened its deliberations in Rome on the initiative of Pope John XXIII, the one Catholic prelate who had said that the church had no enemies. Under the Pope's leadership, another ideological revolution took place in the world's oldest and most traditional global institution. Vatican II was a renewal that would open the way for a new kind of Catholic ideology: the theology of liberation. The division within the Cuban Catholic Church reflected a larger ambivalence within global and Latin American Catholicism. Catholicism, having lost its privileged political and social position, found itself grappling with modernity, and reluctant to endorse liberal, free-market capitalism, or Soviet communism. In the unfortunate context of the Cold War, the Catholic Church desired a "third way"; a form of humanistic and Christian socialism and at the same time strove to maintain as much influence with the state as possible. It was in Cuba in the 1950s that this crisis came to a dramatic climax. The Cuban hierarchy vacillated between the regime and the Revolution and eventually lost both.

Studies 24 (1992): 136; Jose Alvarez Junco, "The Formation of Spanish Identity and Its Adaptation to the Age of Nations," History \& Memory 13.1/2 (Fall 2002): Jose Alvarez Junco, "The Formation of Spanish Identity and Its Adaptation to the Age of Nations," History \& Memory 13.1/2 (Fall 2002): 29; and Aurora G. Morcillo, True Catholic Womanhood, Gender Ideology in Franco's Spain (DeKalb, IL: Northern Illinois UP, 2000), 4. 



\section{CHAPTER V}

THE CATHOLIC UNIVERSITY STUDENT MOVEMENT IN BRAZIL: 1956 TO 1966

"There was an opportunity for an exchange of ideas ... I was not exactly trying to start anything, simply to place on the table certain questions that seemed to me to be important." Frei Romeu Dale (1957). ${ }^{1}$

"The various movements of Catholic Action can help each other find common paths... We must work together with Spanish-speaking countries. Together we can accomplish economic independence." Luis Alberto Gomez de Souza (1957). ${ }^{2}$

The Catholic university student movement in Brazil, called Juventude Universidade Católica (JUC), sought to resolve the tension between church and state and to recover lost ground for traditional Catholic hegemony in the secular social sphere. This was an especially profound challenge in Brazil as a traditionally Catholic society was rapidly transforming itself into a secularized modernity. ${ }^{3}$ This chapter argues that the JUC was successful in its endeavor to influence the secular academic sphere with Catholic values (faith, compassion for the poor, social justice), but it ultimately was a victim of its own success. As the student members of the JUC transcended the dualistic "sacred-secular" division between religion and politics in the period from 1956 to 1966, they became perceived as a political threat to the military and the elites. The church hierarchy was concerned that the JUC was no longer under the control of the church and was too politi-

1 “JUC e a Política Universitária,” Boletim Nacional (1957), 11, Bidegain Papers.

${ }^{2}$ Boletim Nacional (1957) Bidegain Papers.

${ }^{3}$ Emile Poulat, "Catholicism and Modernity: A Process of Mutual Exclusion," in The Debate on Modernity, ed. Claude Geffré and Jean-Pierre Jossua (London: SCM Press, 1992), 11. Tom Buchanan and Martin Conway, in Political Catholicism in Europe, 1918-1965 (Oxford: Clarendon Press, 1996), believe that Catholicism reached the peak of its political influence in the early twentieth century in the Catholic countries of Europe (France, Italy, Portugal, Spain and Belgium) through conservative Catholic integralism and subsequently resisted Liberal, Socialist and Communist parties as well as Protestantism until the growing advent of pluralism and consumerism and Vatican II in the 1960s. 
cized. The Brazilian military dictatorship began to suppress the JUC in 1964, and the church hierarchy ultimately dissolved it in $1966 .^{4}$

Brazil entered a period of political crisis in the 1930s which was only resolved by a change from the traditional oligarchic pact euphemistically called café e leite (coffee and milk), referring to the alternating access to power between the powerful elites of the two dominant states of Rio Grande do Sul (leite) and Rio de Janeiro (coffee) to a new regime under authoritarian populist Getúlio Vargas (1882-1954) and his successors. ${ }^{5}$ Under the populist pact with Vargas, the Catholic Church gained a new level of social influence with state and society which has been called neo-Christendom. ${ }^{6}$ Brazilian neoChristendom reached its zenith in the $1950 \mathrm{~s}^{7}$ In the early $1960 \mathrm{~s}$, this model itself entered into crisis and began to give way when faced with multiple problems of national development, rapid urbanization, extreme poverty, economic underdevelopment and a working class that was increasingly more receptive to secular social ideologies (or Protestant Pen-

\footnotetext{
${ }^{4}$ Beozzo, Cristãos: 52.
}

${ }^{5}$ Souza, A JUC, 45, 62; Laura Da Veiga, "Reform Of The Brazilian University: The University And The Question Of Hegemony (1954-1968)," (PhD diss.: Stanford University, 1981), 1. Note: "The term "populist" is an imprecise term, which has come to be used to describe a style of politician produced in a situation where a mass urban electorate is receptive to a colorful leader who relies on a direct, emotional appeal, based on economic issues of varying ideological sophistication. The populist politician would have been unthinkable before 1930, since his success presupposes a relatively free vote. He is a personalistic leader whose political organization centers upon his own ambitions and career"; see Thomas E. Skidmore, Politics in Brazil 1930-1964: An Experiment in Democracy (Oxford: Oxford UP, 1967), 67.

${ }^{6}$ For descriptions and further discussion of neo-Christendom in Brazil, see Thomas C. Bruneau, The Church in Brazil: The Politics of Religion (Austin, TX: The University of Texas Press, 1982), 149; Andrew Chesnut, Competitive Spirits, 31 and 34; Souza, A JUC, 157; Levine, Religion and Politics, 33, 304-305; Serbin, "Church-State Reciprocity," 726, 730 and 735.

${ }^{7}$ Kenneth P. Serbin, Secret Dialogues: Church-State Relations, Torture, and Social Justice in Authoritarian Brazil (Pittsburgh, PA: University of Pittsburgh Press, 2000), 26. 
tecostalism) than to traditional Catholicism. ${ }^{8}$ This presented growing problems for the Catholic Church hierarchy in Brazil, ${ }^{9}$ who sought a means to be politically and morally engaged with society while avoiding becoming overly politicized. ${ }^{10}$ Ideological formation and International influences: 1956-1960.

The year 1956 was a key turning point for the Brazilian university movement. Although the Brazilian JUC had been affected by numerous transnational influences in the previous years, after 1956 the Brazilian Catholic student movement began to rise to prominant continental and international influence. Also after 1956, the Brazilian JUC began a period of rapid growth and increasingly radical politicization. It was also a year for Internationalism for Rio de Janeiro. The Brazilian JUC hosted the "World Session" of the International Catholic student movement in the summer of 1956. This session followed on the heels of the International Eucharistic Congress held in Rio de Janeiro the previous year. ${ }^{11}$

The World Session in Rio, sponsored by Pax Romana coincided with the tenth anniversary of the first international meeting in Fribourg, Switzerland in 1946. Sixty student leaders participated in the World Session, representing twenty-three student and university movements from ten different countries in Latin and Anglo America, Africa and

\footnotetext{
${ }^{8}$ Laura Da Veiga, "Reform of the Brazilian University: The University and the Question of Hegemony (1954-1968)," diss. (Palo Alto, California: Stanford University, 1981) 1.

${ }^{9}$ For an overview of the struggle between Catholicism and modernity in nineteenth century Europe see Clark and Kaiser, Culture Wars, 21, 28.

${ }^{10}$ To see how Protestantism and Catholicism responded differently to the challenge of modernity, see Christoph Theobald. "Attempts at Reconciling Modernity and Religion in Catholic and Protestant Theology." In The Debate on Modernity, edited by Claude Geffré and Jean-Pierre Jossua (London: SCM Press, 1992), 27, 31.
} 
Europe. The International bulletin described the meetings as being characterized by intense religious devotion with daily meditations. The principal theme was the role of Catholic students in the rapidly evolving forms of education. ${ }^{12}$ Father Romeu Dale, the national advisor to the Brazilian JUC, led discussions about the "Common Foundations" of the transnational Catholic university movement. ${ }^{13}$ Brazilian students had been involved in the development of the international Catholic university movement since a meeting of student movements in Chicago in 1948 sponsored by Jeunesse Catholique Etudiant International (JECI). ${ }^{14}$ The World Session in Rio marked the rising international influence of the Brazilian JUC movement as a representative of Catholic students from Latin America.

The secular Brazilian National Student Union (UNE) also met in 1956 for its nineteenth annual Congress. ${ }^{15}$ UNE had been predominately under the leadership of moderate to conservative students groups since 1950. The progressive-left sectors of the student union regained permanent control of UNE in 1956. As student members of the JUC also moved toward the political left, they gained influence within the spectrum of student groups represented in the student union, and by the early 1960s, Catholic students leaders and former members of the JUC were winning the presidency of the UNE. The

${ }^{11}$ Serbin, "Church-State Reciprocity," 721.

${ }^{12}$ JEC International Bulletin, July-August 1946: 3, Bidegain Papers.

${ }^{13}$ Beozzo, Cristãos: 55.

${ }^{14}$ The Jeunesse Catholique Etudiant International (JECI) was a younger organization than Pax Romana, and represented French style specialized Catholic Action which tended to be more militant, more class oriented and more independent of clerical control.

${ }^{15}$ União Nacional de Estudantes. 
National Student Union assumed increasingly radical nationalist (and anti-American) positions against the presence of foreign corporations. ${ }^{16}$

1956 was also a period of transition for the Brazilian Catholic university organization. The membership of the JUC grew rapidly resulting in organizational growing pains. The JUC was partially decentralized in order to allow important regional centers such as São Paulo and Belo Horizonte to have greater latitude in taking initiative. Discussions centered on an analysis of issues such as nationalism, education, worker's concerns and university politics. The JUC encouraged Catholic students to reflect deeply on their responsibility as Christians to participate in seeking solutions to these problems. ${ }^{17}$

Brazil was in the midst of a population explosion which contributed to large labor migrations between regions and severe social inequalities. By 1960, Brazil's fertility rates were among the highest in the world. The population growth rates strained the Brazilian economy. The urban population grew the most rapidly, rising from thirty percent in 1940 to forty percent in 1950, and contributing to the rapid spread of favelas or urban shantytowns. ${ }^{18}$ Because the fastest growing portion of the urban population was children, education and health care services were severely stretched and under-funded. ${ }^{19}$ Brazilian university students were keenly aware of these growing strains in Brazilian society. Catholic students felt that they had a responsibility to recognize these issues and to seek answers

${ }^{16}$ Souza, A JUC: 83.

17 “La J.E.C. dans le Monde: Le Brésil,” JEC International Bulletin (1956): 7, Bidegain Papers.

${ }^{18}$ Thomas E. Skidmore, Brazil: Five Centuries of Change (Oxford, UK: Oxford University Press, 1999), 138.

${ }^{19}$ Ibid. 
to Brazilian problems as part of their Christian responsibility and in order to have credibility with secular students. The bishops encouraged this sense of responsibility toward social engagement. ${ }^{20}$

The Catholic student movement recognized the challenge of balancing the tension between religion and politics. The 1957 national bulletin for the JUC included an article called "JUC and University Politics" that discussed the importance of gaining Christian (Catholic) influence in the secular academic environment. The author proposed a model of "incarnation" in which Catholic students were to model Christian values and solutions within each academic faculty. ${ }^{21}$ What exactly were these Christian "values" was an area for potential misunderstanding and disagreement between the hierarchy and the students. The traditional Catholic values were prayer, religious devotion, respect for authority, the patriarchal family, ultramontane faith, and a harmonious social order. ${ }^{22}$ Catholic progressives and students gradually began to emphasize a different set of values more in harmony with the social teaching of the church and economic equality. ${ }^{23}$

According to the article in the JUC bulletin, it was through the JUC that the "militant" Catholic student ought to discover the possibility of social action and receive divine motivation for political engagement in the university. It was also in the JUC where the

\footnotetext{
${ }^{20}$ Pius XII, Guiding Principles of the Lay Apostolate, Rome: Second World Congress of the Lay Apostolate October 5, 1957.

21 “JUC e a Política Universitária,” Boletim Nacional, 1957: 5, Bidegain Papers.

${ }^{22}$ Ultramontane was coined in the nineteenth century to describe the view that the Catholic Church must submit to papal authority rather than national bishops or councils. It means "over the mountains."

23 “JUC e a Política Universitária,” Boletim Nacional, 1957: 7, Bidegain Papers.
} 
militant was to develop Christian principles such as loyalty to the common good, social consciousness, charity, fraternity, etc., and should learn to put them into action. The author observed that it was inevitable that a large number of jucistas would eventually become politically militant. The article emphasized the importance of keeping a careful distinction between the JUC as an organization and individual Catholic students acting on political convictions formed by their own conscience. The article also pointed out the importance of remembering that the JUC was not intended to be a political party; if the JUC were to become radically politicized, it could have disastrous consequences for the future of the Catholic student movement. ${ }^{24}$

In addition to Brazilian 'nationalism,' there was also a growing 'third world' internationalist sentiment within the JUC. Luis Alberto Gómes de Souza, a student leader of the Brazilian JUC (quoted at the beginning of this chapter), wrote an article in the 1957 JUC bulletin in which he documented his travels to El Salvador, Central America, via Caracas in July. ${ }^{25}$ He was attending a hemispheric, pan-American meeting of Catholic student leaders who gathered to work together on developing a four-year plan for extending the Catholic university movement throughout Latin America. The Assembly was sponsored by Pax Romana and had originally been planned to meet in Havana but was

${ }^{24}$ Boletim Nacional, 1957: 6.

${ }^{25}$ Luis Alberto Gómes de Souza and his future wife, Lucia Ribeiro, were student leaders of the JUC in the university in Bello Horizonte, Minas Gerais. After serving in a position of national leadership in the JUC, he became the regional (continental) leader for the South America, and, in 1959, was appointed leader of the internatioinal JECI in Paris. He became a sociologist and has written numerous books, one of which, A JUC: Os Estudantes Católicos e a Política, is about the political significance of the JUC. The author of this dissertation interviewed him in his home in Rio de Janeiro in 2005; Luis Alberto Gómes de Souza, “Aventura pelas Americas," Boletim Nacional, 1957: 23. 
moved because of the Cuban Revoltion that was underway. The Pax Romana meeting was not only pan-American, but truly global, including student delegates from Malaysia, Viet-Nam, Celyon and one delegate from the Philippines. Student delegates from a Catholic university in Poland also attended. ${ }^{26}$

After the meeting in El Salvador, Luis Alberto continued on to the United States and Canada. He spent a month in the United States and attended several nation-wide conferences at Newman clubs and the National Federation of Catholic College Students as well as the secular National Students Association, the U.S. equivalent of the Brazilian UNE. He observed that the U.S. form of the JUC, known as the YCS (Young Catholic Students) was very small but practiced an intense spirituality. In Montreal he visited the French-Canadian version of student Catholic Action, the JEC. ${ }^{27}$ In his opinion, the specialized student movements in Quebec were similar to the Brazilian version. Luis Alberto was impressed with the French-Canadian Catholic student movement, their publications and their outreach to secondary schools. ${ }^{28}$

The transnational Catholic university movement was not just a European or PanAmerican phenomenon. The International Catholic Students organization based in Paris (JECI) was active in nations of Africa, Asia and the Middle East which had significant

${ }^{26}$ Boletim Nacional, 1957: 24.

${ }^{27}$ In French speaking countries, the Catholic student organizations were called JEC: Jeunesse Catholique Etudiant (Young Catholic Students) whereas in Brazil and most of Latin America, "JEC" was only used to refer to the work amongst elementary and secondary students and JUC (Juventude Universitaria Catholica) was used to refer to the university organizations. In this dissertation, "JEC" will always be used to refer to secondary and elementary organizations unless specifically referring to organizations in France, Belgium or Quebec. The primary focus here is on the university movements in Cuba and Brazil (JUC).

$$
{ }^{28} \text { Ibid. }
$$


Catholic populations as well as in Latin America and Catholic Europe. In recognition of the transnational nature of the Catholic university movement and the importance of the student movements in the developing world, the 1958 World Session of JECI was held in the western-most point of Africa, at Dakar in Sénegal. The delegation from Brazil included four young women and two male student leaders the High School movement and two more university students from the JUC and the national advisor (Father Dale). During the World Session in Dakar, the Brazilian student leader, Gómez de Souza, was elected to be General Secretary of the international student organization (JECI), further illustrating the increasing influence of the Brazilian JUC within the transnational Catholic university and student movements. ${ }^{29}$ The student movement seemed sensitive to anti-colonial sentiment in the developing world and appeared to be making every effort to move away from a European-centered organizational structure by holding World Sessions in Africa and by electing student leaders from developing nations to positions of international leadership.

The Brazilian Catholic university movement initiated a significant organizational transition at the National Council meeting in 1958. At the same time, there was a generational transition underway. Although the JUC continued to experience rapid growth, some of the older veteran student militants became dissatisfied with the changes. In the view of Brazilian historian, José Oscar Beozzo, this represented a transition from a devout and studious older generation of Catholic students to a younger more energetic co-

\footnotetext{
${ }^{29}$ Padim, interview, May 28, 1990.
} 
hort of students who had been recruited and trained in the secondary school with the training methods of specialized Catholic Action. ${ }^{30}$

Membership in the Brazilian JUC rose exponentially in 1959 leading to further organizational growing pains. The challenge was how to incorporate large numbers of new members effectively into the activist philosophy of the Catholic university movement. Leaders of the student movement had to consider new approaches to negotiating the transition of members from secondary school to the university level and then another significant life transition as they graduated and entered into professional careers. There were efforts to improve communication such as changes in the bulletin format to enhance simplicity and better thematic focus in each issue. ${ }^{31}$

The university movement incorporated a wave of future leaders during this growth period, many of whom rose to key positions of leadership in the early 1960s. Some of these leaders were later interviewed about their Catholic university experiences and these interviews were recorded and stored at the CEDIC center at the Pontifical Catholic University of Sao Paulo. ${ }^{32}$ As part of the research for this dissertation, forty hours of recorded interviews were consulted. Once such student, Darcy Corazza, went to Rome in 1956 to study for the priesthood and returned to Brazil in 1960 to become an advisor to the JUC until 1965. Another former student, Walter Borelli, began working

\footnotetext{
${ }^{30}$ Pope Pius XII, The Lay Apostolate, Its Need Today: An Address of Pope Pius XII to the World Congress of the Lay Apostolate, October 14, 1951., United States Catholic Conference (Washington, DC: National Catholic Welfare Conference, 1951).

${ }^{31}$ JUC boletim nacional, No. 5/1959. Bidegain Papers.

${ }^{32}$ Programa de Historia Oral, Centro de Documentação e Informação Científica (São Paulo, Brazil: Pontíficia Universidade Católica de São Paulo).
} 
with the Catholic university movement in 1959 and continued until the military crackdown in 1964. Also in 1959, 13-year-old Carlos Alberto Libanio Christo, later popularly known as Frei Betto, came into contact with the student movement in middle school through Dominican priests. ${ }^{33} \mathrm{He}$ joined the high school branch of the student movement in Bello Horizonte at age 15. Jose Roberto Correia Soeiro also joined the Catholic student movement in 1959 at age 15 while in high school, and later went to Rio to be part of the National Team of the student movement from 1962 to $1965 .{ }^{34}$ Elisa de Carvalho, became involved with the student movement in a Catholic high school. She later became heavily involved with the JUC at the university level where she met her future husband, José Juliano de Carvalho Filho. ${ }^{35}$ The oral histories of these and other former students served as primary sources for the research for this chapter.

There was a convergence of intellectual and geo-political factors in 1959 that provided a context for the ideological development and radicalization of the Brazilian JUC. A noted Brazilian economist, Celso Furtado, published a book on the economic history of Brazil that emphasized dependency theory and became popular among Catholic university students as an explanation for the economic disadvantages of Brazil and Latin America compared to the United States. ${ }^{36}$ Dependency theory elaborated the idea that

\footnotetext{
${ }^{33}$ Frei Betto became a well known author of liberation theology and is best known for his book about his interview with Fidel Castro: Frei Betto, Fidel Y La Religion: Conversaciones Con Frei Betto Sobre El Marxismo Y La Teologia De La Liberacion (Bogotá, Colombia: Oveja, 1986).

${ }^{34}$ Carlos Alberto Libanio Christo (Frei Betto), interview. Säo Paulo, Brazil, July 8,1997; Jose Roberto Correia Soeiro and Vera Lucia Rossi Soeiro, interview. Säo Paulo, Brazil, Febuary 11,1997.

${ }^{35}$ Elisa de Carvalho and José Juliano de Carvalho Filho, interview, January 3,1990.
} 
since developing nations were primarily exporters of raw materials, and importers of value-added manufactured products, the developing nations would only continue to fall further behind the industrial nations in the race to industrial development. Over time, according to the theory, the cost of manufactured goods would inevitably rise while the cost of raw materials would decline. According to dependency theory as later elaborated by Andre Gunder Frank, Immanuel Wallerstein and the future president of Brazil, Henrique Cardoso, the industrial nations became the "core" of a economic world system and the "peripheral" developing nations of South America, Africa and Asia languished as useful sources of raw materials and cheap labor to be exploited. In effect, it was viewed as a zero-sum game in which the prosperity of the core nations of industrialized Europe and North America came at the expense of the poorer nations. Although recent scholarship has come to view dependency theory as being overly simplistic, it was just coming into vogue during the rise of the Catholic student movements and seemed to provide a clear explanation for poverty and injustice in Latin America that dovetailed nicely with nationalist and anti-imperialist sentiments. ${ }^{37}$

A team of Catholic student militants from the economics department at the University of Belo Horizonte, in the capital city of the Brazilian state of Minas Gerais, began

\footnotetext{
${ }^{36}$ Celso Furtado, The Economic Growth of Brazil, originally published in 1959 in Portuguese as Formação Econômica do Brasil, Cambridge Latin American Studies (Cambridge, England: Cambridge University Press, 1965).

${ }^{37}$ For more on dependency theory see: Stanley Stein and Barbara H. Stein, The Colonial Heritage of Latin America: Essays on Economic Dependence in Perspective (Oxford: Oxford University Press, 1970); Immanuel Wallerstein, The Modern World System: Capitalist Agriculture and the Origins of the European World Economy in the Sixteenth Century (New York: Academic Press, 1974); Fernando Henrique Cardoso and Enzo Faletto, Dependency and Development in Latin America, Marjory Mattingly Urquidi (Berkeley: University of California Press, 1979); Tulio Halperín Donghi, “"Dependency Theory'
} 
discussing the need for structural economic reforms. At the annual council meeting in Campinas in 1958, these Mineiro jucistas were severely critical of the direction of the Catholic university movement, proposing more serious engagement of the JUC to effect structural social change. These young Catholic economics students also continued to exercise significant influence at the National Council meeting of the JUC when it was held in Belo Horizonte in 1959. They advocated a firm commitment to address poverty, dependency, underdevelopment and concrete structural reforms for Brazilian social problems. ${ }^{38}$

Geo-political factors in 1959 contributed to changing dynamics for students. The success of the Cuban Revolution, supported by many progressive-left priests and militant Catholic students, made daily headlines in Brazil. The Correio do Povo of Rio de Janeiro carried daily front-page articles about the Cuban Revolution—often even two or three articles on the same day. ${ }^{39}$ The Cuban Revolution seemed to hold promise for charting a non-capitalist course of development and agrarian reform and was not yet seen as antagonistic toward Catholicism. The example of the revolution seemed to stir liberationist breezes and new hopes of overthrowing dictatorships everywhere in Latin America. A former member of the JUC, Jose Roberto Correia Soeiro, recalled in an interview the influence of Cuban Revolution and the atmosphere of the Cold War on student perspectives. According to Correia Soeiro's perspective, "We were fomenting a social revolution

and Latin American Historiography," Latin American Research Review, Vol. 17, No. 1 17, no. 1 (1982); Octavio Ianni, O Labirinto Latino Americano (Petrópolis: Editora Vozes, 1995).

${ }^{38}$ Beozzo, Cristãos, 59.

${ }^{39}$ Correio Do Povo, Porto Alegre: January 22, 1960: (Gainesville: Latin American Collection and University of Florida). 
in Brazil. Under the influence of the Cuban Revolution in 1959, there was a revolutionary social move toward egalitarianism which made the church uncomfortable and created conflicts between the movements and the local bishops. ${ }^{, 40}$ Frei Betto, a student militant from his teen years, was also deeply influenced by the Cuban Revolution and traveled Cuba to talk with Che Guevara and later interviewed Fidel for a book on Castro's views about religion. ${ }^{41}$

This was a time of revolutionary ferment in all of Latin America and there was a general desire to rid the hemisphere of corrupt dictators. Revolution seemed to be in the atmosphere. Numerous newspaper items told of attempts to overthrow General Alfredo Stroessner in Paraguay. ${ }^{42}$ The dictatorships of Anastasio Somoza in Nicaragua and Rafael Trujillo in the Dominican Republic were also threatened with rumors of the invasion by Cuban troops. ${ }^{43}$ Frequent articles appeared in the Brazilian press expressing criticism of the aging dictatorships of António de Oliveira Salazar in Portugal and Francisco Franco in Spain. ${ }^{44}$ The Catholic university movement in Brazil and the rest of Latin America flourished in a geo-political context that appeared to favor revolution.

Not only did the revolutionary movements emanating out of Cuba dominate the headlines, but there were also a discussion in Brazilian newspapers of potentially revolu-

\footnotetext{
${ }^{40}$ Jose Roberto Correia Soeiro and Vera Lucia Rossi Soeiro, interview, Feburary 11, 1997.

${ }^{41}$ Betto, interview, July 8,1997.

42 "Quinze Mil Exilados Na Argentina Procuram Obter Armas e Dinheiro para a Revolta Contra Stroessner," Correio Do Povo, Porto Alegre, March 13, 1959, Latin American Collection.

43 "Fidel Castro Contra Todas as Ditaduras," Correio Do Povo, Porto Alegre, April 21, 1959, Latin American Collection,
} 
tionary changes going on in the Catholic Church. In January 1959, the new pope, John XXIII, called for an ecumenical council to be held in Rome. ${ }^{45}$ Few observers foresaw the far reaching and complex changes that would take place in the Second Vatican Council. Although the changes actually initiated in Vatican II were more moderate than radical, it can be argued that they destabilized weak structures inherited from traditional nineteenthcentury Catholicism. The unintended consequence of these changes resulted in the loss of "rule-making" moral authority of the church hierarchy and the flourishing of significant dissent among Catholics on issues about rules for moral conduct, sacramental and communal traditions. ${ }^{46}$

At the National Council of the JUC in Belo Horizonte in 1959, Padre Almeri Bezerra gave a series of talks about the "Historical Ideal" (Ideal Histórico). The concrete historical ideal was a concept of an ideal social essence that was possible to actualize in a given historical period, and representing a relative level of social and political perfection. Jacques Maritain, introduced previously, first articulated the concept of the concrete historical ideal as a realistic alternative to theoretical and unachievable utopias. Marx had criticized both the historical ideal and utopianism without distinguishing between them. ${ }^{47}$

44 “The People of Portugal Are Growing Tired of Oliveira Salazar," Correio Do Povo, Porto Alegre, January 17, 1959, Latin American Collection.

45 "No se convocará al Concilio Ecuménico antes de 2 años,” Diario de la Marina, Feburary 5, 1959; “Al margen del XX Concilio Ecuménico” Diario de la Marina, Feburary 14, 1959; Interesa la celebración del Concilio Ecumenico en Roma: Recibe buena acogida el llamamiento hecho por Su Santidad el Papa hace algunas semanas" Diario de la Marina, Feburary 18, 1959.

${ }^{46}$ Andrew M. Greeley, The Catholic Revolution: New Wine, Old Wineskins, and the Second Vatican Council (Berkeley, Calif.: University of California Press, 2004) 33.

\footnotetext{
${ }^{47}$ Maritain, Integral Humanism, 130.
} 
Maritain sought to correct this by emphasizing the possibility of practical realization of a potential historic ideal for a given historical epoch. ${ }^{48}$

As mentioned above, the Catholic militants from the university in Belo Horizonte presented new ideas about the core problems of development and nationalism and they attempted to elaborate a vision of an historical ideal for Brazil from a socialist perspective. The group from Belo Horizonte continued to be very influential in 1960 in the tenyear anniversary Congress of the JUC. They eventually participated in the formation of a radical left, non-confessional political party called the Ação Popular (AP). ${ }^{49}$

The Brazilian JUC continued its rise to regional and international prominence in 1959. Luiz Alberto Gómez de Souza of the national JUC team moved to Paris to be installed as the Secretary General of International Catholic Student (JECI) organization. The Brazilian student organizations--the secondary school JEC and the university JUCtook a leading role in spearheading regional coordination of specialized Catholic Action groups in Latin America. At a regional meeting in 1959 in Rosario, Argentina, the Brazilian delegation proposed stronger networking and coordination among Latin American university organizations..$^{50}$

\footnotetext{
${ }^{48}$ For more on the concept of a concrete historical ideal see Jacques Maritain in Integral Humanism, first published in French in 1936 and later developed by Emmanuel Mounier in his Personalist Manifesto also published in French in 1938: see Joseph Amato, Mounier and Maritain: A French Catholic Understanding of the Modern World (The University of Alabama Press, 1975), 144; Jacques Maritain, True Humanism, Translated by Margot Adamson (New York: Scribner's, 1938), 121.

${ }^{49}$ In this context, the author uses "non-confessional" to mean that the AP was not affiliated with the Catholic Church, although it was made up largely of former Catholic students. Beozzo, Cristãos,42-43, 59 .

${ }^{50}$ Luiz Alberto Gómez de Souza to Dom Carlos Alfaro, CELAM. Bogotá, Colombia (Paris, France, 1960), 1, Bidegain Papers.
} 
Not long after the meeting in Rosario, a continent-wide Secretariat for the JUC in Latin American was formed under Brazilian leadership. The Catholic university movement in Brazil progressively gained a prominent international leadership role without neglecting its continued focus on Brazilian social problems. As reflected in the quote from Gómez de Souza at the beginning of this chapter, the Brazilian JUC realized that Brazilian problems were not isolated from Latin American problems and that the best chance of initiating change required some degree of international solidarity between Brazilian students and Catholic students from Spanish speaking countries. The Brazilian students began aggressively exporting their vision for social change in an effort to awaken university students from other countries in Latin America to their Christian responsibility for the development of just social structures in their respective societies. ${ }^{51}$

The Brazilian Catholic university movement was now in a prominent leadership role within the transnational Catholic student movements. Gómez de Souza communicated with the Latin American Bishops Conference (CELAM) reporting on the activities of the newly formed regional Secretariat for South America. ${ }^{52}$ According to the letter, Cosme Alves Ferriera Neto and Elsa Figueredo, former student members of the Brazilian JUC, traveled extensively throughout Argentina, Uruguay and Colombia in June of 1959, promoting the formation of new national chapters of the JUC. Another student militant, Celso José Mendes Guinaraes, the ex-national director of the Brazilian JUC, traveled in September of the same year on a world tour to Venezuela, Haiti, the Dominican Repub-

\footnotetext{
${ }^{51}$ Beozzo, Cristãos, 56.

${ }^{52}$ Conferencia Episcopal para Latino-America, with headquarters in Bogotá, Colombia.
} 
lic, Cuba, Mexico City, Honduras, El Salvador, Nicaragua, Costa Rica, Panama, Colombia, Ecuador, Peru, Chile, Paraguay and finally back to Rio de Janeiro as part of an effort to expand the work of the JUC in Latin America. His travel costs were covered by a grant from the United Nations Educational, Scientific and Cultural Organization (UNESCO) ${ }^{53}$

Gómez de Souza outlined plans for the coming year, which included a possible international meeting of Catholic students at a congress of Catholic Action in Mexico, additional promotional and organizational trips by members of the South American Secretariat to the Southern Cone (Argentina, Chile, Bolivia and Uruguay), plans to encourage as many Catholic student as possible to attend a World Student Session in Germany in August of 1961, and plans for a Central American student session sponsored by JECI that had originally been scheduled for Havana but was forced to relocate because of the tense political situation in Cuba. ${ }^{54}$

The 1959 JUC bulletin included an example of the new ideological influences in the Catholic student movement. There was a brief bio of Emmanuel Mounier, a French Catholic philosopher and activist, along with a review of his most recent book. Mounier was critical of the heavy emphasis on individualism in Western capitalism and called for dialogue between Christians and Marxists. The bulletin reviewed the first Portuguese language translation of Mounier's book, La Petite Peur Du XXe Siècle (Shadow of fear in the Twentieth Century). Published in Brazil in 1958, the book was based on a series of

\footnotetext{
${ }^{53}$ Souza, letter (1960): 2.

${ }^{54}$ Ibid., 3.
} 
three lectures given by Mounier in Paris in 1946-1948. ${ }^{55}$ Mounier was also the editor of an influential French Catholic journal called Esprit, which examined current social issues from a Catholic-left perspective and provided a consistent Catholic voice for reform and went as far as advocating a humanist revolution. ${ }^{56}$

Brazil entered into a year of new confidence and surging optimism in 1960, including some international cultural celebrity through its innovative artistic and musical movement known as Tropicália. Also from 1958 through 1962, Brazil was in the middle of its golden era of world soccer championships with the star player Edson Arantes do Nascimento (Pelé). Juscelino Kubitschek had initiated building a new city, Brasilia, in the interior to serve as Brazil's capital. Construction of Brasilia was completed in April 1960 and the new capital was officially inaugurated by President Kubitschek. Finally, presidential elections were held in 1960 leading to the peaceful assumption of power of a new president, Janio Quadros. In terms of the economy, in 1960 Brazil was relatively prosperous with a fairly diversified industrial structure. The balance of payments problems caused by import substitution strategy did not become apparent until after 1962. Thus, despite chronic rural poverty and income inequality Brazil seemed to be on the ascendency on the world stage. ${ }^{57}$

Several former members of the JUC recalled the Catholic student movement of the early 1960s in interviews carried out almost two decades later. One former student

\footnotetext{
${ }^{55}$ Paul Ricoeur, History and Truth, trans. Charles A. Kelbley, Northwestern University Studies in Phenomenology \& Existential Philosophy (Evanston, IL: Northwestern University Press, 1965) 148.

${ }^{56}$ Amato, Joseph Amato, Mounier and Maritain: A French Catholic Understanding of the Modern World (The U of Alabama P, 1975) 158.
} 
militant, Luis Eduardo Wanderly, became a member of the national team of the JUC in 1960. His responsibility with the national team required extensive traveling around Brazil. He recalled observing rapid changes in the JUC in 1960. He was put in charge of an area that included the state of Minas Gerais and was shocked that the group in capital city of Belo Horizonte was critical of the more conservative São Paulo chapter. In his recollections, the affinity toward Marxism was growing in 1959 and 1960 and consequently conflicts with some of the conservative clerical advisors increased. ${ }^{58}$

Also during this time Walter Borelli, another student leader who was interviewed in 1990, joined the JUC when he entered the faculty of Economics at the University of São Paulo. He worked with the JUC from 1959 through 1964 as part of the "Pilot Team" in Economics and in the Political Team as the representative of São Paulo. In 1961 he was invited to give a presentation with a focus on economics at the 10 -year anniversary celebration. Borelli observed that there were significant ideological differences between the politicized JUC chapter in Minas Gerais and the more conservative JUC group in São Paulo. The São Paulo chapter was much more oriented around a religious vision. According to Borelli, this was shortly before the period of Vatican II, and most people who went to church did so for reasons of piety. Many student members of the JUC did not participate in the religious activity of the church. Rather, they were drawn to the opportunity for social activism. ${ }^{59}$

\footnotetext{
${ }^{57}$ Skidmore, Politics in Brazil, 167.

${ }^{58}$ Wanderly Interview, September 27, 1988.

${ }^{59}$ Walter Borelli, interview. January 26, 1990.
} 
After Walter left the Regional Team, things began to change rapidly. In his opinion, it was more and more difficult to engage in political action from within a Catholic organization. Walter began working with the radical Ação Popular party (AP) in this period. AP arose to provide space for direct partisan political action which was very awkward from within the Catholic Action movements because of the tension it generated with the clergy. Borelli recalled that there was often a "double militancy of members of JUC and AP in the beginning. ${ }^{.60}$ During this period things happened very fast. Brazilian social and political realities could change totally in the two to four years that one was studying in the university. After he left Ação Popular, Borelli experienced a profound political disillusionment; he no longer belonged to any political group. He avoided political commitments and instead sought out professional groups, especially economists. He did not get involved again politically until the election of former union acitivist and leader of the workers party, Inacio Lula da Silva to the Brazilian presidency in 2002. ${ }^{61}$

Joseph Nagamine, another former member of JUC, recalled the emergence of radical communist parties in the 1960s, such as the Trotskyite Communist Party. It was in this radicalized political context that the National Student Union (UNE) had a series of presidents who were Catholic and former members of the JUC. In Nagamine's view, which coincided with the recollections of many others, the Ação Popular was born directly out of the Catholic student JUC. Nagamine recalled the intense discussions among top level JUC activists during a series of meetings including the UNE Congresses in 1960

\footnotetext{
${ }^{60}$ Borelli, interview. January 26, 1990.

${ }^{61}$ Ibid.
} 
and 1962 and the JUC Congress of 1961 (the 10-year anniversary of JUC) in which a consensus developed among the Catholic student leaders that the formation of a separate, non-confessional political organization was necessary. Based on the initial results at these preliminary meetings, several organizational meetings were held in São Paulo and Belo Horizonte. $^{62}$

Wanderly was of the opinion that there was a very strong radical leftist orientation emerging during this period within the JUC, especially in the chapters in Belo Horizonte and Rio de Janeiro. This led to conflicts within many of the JUC teams who were ambivalent about the trend toward a synthesis of progressive Catholicism and socialism. Wanderley stated that around 1959 the JUC started to become more politically radical with the intellectual influence of Emmanuel Mounier. According to his recollections, the JUC engaged in a great debate with the Partido Comunista (communist party). Wandederly also recalled having Mounier's journal "Espirit” sent to him from France. The articles in the journal often advocated seeking to engage in dialogue and even making common cause with Marxism. ${ }^{63}$ Walter Borelli's memory coincided with Wanderley's perceptions: "We in the JUC began to develop relationships with the communists.",64

In Wanderly's opinion, the Second Vatican Council, which opened in October of 1962, sought self-contradictory aims. The Council bishops sought to be anti-communist at the same time as they were trying to encourage change of unjust social structures. It

\footnotetext{
${ }^{62}$ Joseph Nagamine, interview, November 3, 1988.

${ }^{63}$ Wanderly, interview. September 27, 1988.

${ }^{64}$ Borelli, interview, January 26, 1990.
} 
was toward the latter end of this period of intense radicalization, that many militant members of JUC opted to become involved in the rural literacy campaigns and the base education initiative, or MEB, (movimento da educação de base) of the Catholic Church as a tangible expression of their faith and social commitment. Wanderley's own personal involvement with the MEB movement took place between the years of 1962 and $1964 .{ }^{65}$

In July of 1960, a commemorative Congress of the tenth anniversary of the Brazilian JUC was held in Rio de Janeiro with five hundred participants representing twenty different Brazilian states in addition to student representatives from Argentina, Uruguay and Colombia. The theme of the Congress was the "Historical Ideal," and was obviously inspired by the influence of Maritain and Mounier. There were a number of workshops and presentations around the theological and biblical aspects of the historic ideal and pedagogy, practical applications for Brazil, implications for economics, national development, university politics and the role of women in the university. Perhaps the most potentially controversial topic of the 1960 National Council meeting was the theme of university reform in Brazil. University reform became the primary focal point of struggle for change in the university student movement over the next few years. ${ }^{66}$

Gómez de Souza observed in an article in the JUC bulletin in 1960 that the JUC helped students learn to act in reality (actuar en la realidad) through the See-Judge-Act method. There was always a pervasive concern for action in the world (ação no meio) as

${ }^{65}$ Wanderly, interview, September 27, 1988.

${ }^{66}$ The university autonomy (co-gobierno) of the 1918 Córdoba University Reform movement spread through Latin America but never reached Brazil. See Beozzo, Cristãos, 43-44. 
part of the process of spiritual and political formation in the students. Gómez de Souza also discussed issues related to student politics. In his view, opening the possibility of a genuine Brazilian revolution to students was an effective way to increase interest in direct action on social structures. Jucistas had an obligation to participate in the leadership of university movements such as UNE in order to bring Catholic influence to bear on the Brazilian society. In his view, in a young and underdeveloped country like Brazil, a heavy burden of responsibility rested upon the shoulders of the youth and students. ${ }^{67}$ Reform or Revolution: 1961-1964

In the 1960s, profound political changes were taking place in Brazil and shaking established institutions. The Catholic university movement became politically radicalized. As noted above, the trend within the Catholic JUC was toward collaboration with socialists and communists in order to bring about social change. On June 17, 1961 the national leadership of the Catholic university movement released a manifesto to this effect which caused considerable controversy within liberal and conservative Catholic circles. $^{68}$

In August 1961, Brazil began a descent into a serious political crisis. The rather eccentric president, Janio Quadros, resigned in what was probably intended as an illadvised power grab. He was eventually replaced by populist Vice-President João Goulart despite the strong misgivings of the military and traditional Brazilian elite. In an attempt to build his own political power base, Goulart swung far to the left and courted the sup-

\footnotetext{
${ }^{67}$ Luis Alberto Gómez de Souza, “JUC, Movimento Pedagógico," working document, 2-4, Bidegain Papers.

${ }^{68}$ Therry, "Dominant Power Components," 33.
} 
port of Brazilian nationalist groups. Goulart attempted to pursue an independent foreign policy by withdrawing Brazil from political-military blocs, courting Cuba and welcoming a Chinese trade mission to Rio de Janeiro. ${ }^{69}$

The Catholic university movement was affected by the political climate and also experienced a process of radicalization. Some students and clerical advisors began to question traditional Catholic views on family and gender issues in the early 1960s. Luis Alberto Gómez de Souza, in his letter to the Latin American Bishops Conference (CELAM), called attention to the need for the JUC reconsider the situation of women. ${ }^{70}$ Father Romeu Dale resigned from his post as national advisor to JUC at the end of 1961. Before he resigned, however, Dale prepared a talk about gender roles. Dale talked about the need for a social revolution in family life in the area of ideas and aspirations in the life of women. He spoke of the need to "break the patriarchal regime within the Brazilian family," and substituting for it a communitarian regime. ${ }^{71}$ Dale was critical of the "patriarchal form of the bourgeois family and conditions that cause women to limit themselves to household administration, laundry, cooking, and cleaning., ${ }^{, 72}$ Dale deplored the fact that most women, after graduating from secondary school, only felt free to consider pursuing a university degree if they did not have a boyfriend. Marriage was often the only real career for women in this "antiquated mentality.",73

\footnotetext{
${ }^{69}$ E. Bradford Burns, A History of Brazil (New York: Columbia University Press, 1980) 492.

${ }^{70}$ Souza, “JUC, Movimento Pedagógico,” 2-4, Bidegain Papers.

${ }^{71}$ Romeu Dale, “Qual o Papel Da Mulher?” unpublished essay (1961): 1, Bidegain Papers.

${ }^{72}$ Ibid.
} 
Dom Cândido Padim, auxiliary bishop of Rio de Janeiro, was appointed to replace Dale as the new national advisor for the JUC in August of 1962. This was the first time that a bishop was given the responsibility to advise the student movement. Padim had himself been a student member of the Catholic student movement in the 1930s before he became a priest. Dom Padim systematically began to visit all of the JUC centers in the country. Although he was initially greeted with suspicion and cynicism, his openness to dialogue and engaging manner soon earned the confidence of the student leaders. ${ }^{74}$

In 1962, the student movement began to excersize significant influence on the political life of the country. The leaders of the secular student union, UNE, had direct access to President João Goulart. In 1962 there were only about one hundred thousand students in a country of fifty million inhabitants. ${ }^{75}$ Nevertheless, the prestige of the Brazilian university movement was much greater than its numbers would warrant. This was owing to the long tradition in Latin America of university students bearing a certain level of social responsibility as intellectual elites. It was also in part caused by to the vocal strength of the growing student movement in the increasingly delicate political situation. ${ }^{76}$

It was precisely at this time that the Catholic student movement obtained a prominent role of leadership within the secular national student union. Vinicius Caldeira Brant,

${ }^{73}$ Ibid.

${ }^{74}$ Sousa, A JUC, 203.

${ }^{75}$ According to K. H. Silvert, in the mid-1950s there were in all Latin America only about 350,000 registered students in institutions of higher learning, both state and private. About 40 percent were in Argentina. Despite some disagreement about counting theological schools or fine arts institutes, the highest number, in Silvert's opinion, could not exceed 550,000 for 1960 compared to 4 million students in the United States. K. H. Silvert, "The University Student," Continuity and Change in Latin America, Ed. John J. Johnson (Stanford, Calif.: Stand; Stanford University Press, 1964), 11; 
a former Catholic student leader (JUC) from Belo Horizonte, was elected as the first Catholic student President of UNE in July by 800 student delegates at the UNE Congress in Petrópolis. His election was secured by a strategic alliance between Catholic and communist students. ${ }^{77}$ This alliance between Catholic and communist students caused no small consternation among conservative and traditional Catholics.

In October 1962, the historic Second Vatican Council opened in Rome. Some scholars have described Vatican II as a revolution within Catholicism. ${ }^{78}$ Pope John XXIII was keenly aware that the Church was had grown out of touch with the times and desperately needed to come to grips with modernity. The fathers of the Council agreed with the Pope that change was necessary. Although there was a consensus in favor of the need for change, it proved impssible to anticipate the destabilizing effects on the structures of the church. In the opinion of some, the traditional pre-Vatican II Church had crystallized into a hardened structure of Catholic "rules" of doctrine and moral behavior that were designed to resist the effects of the Enlightenment and French Revolution. ${ }^{79}$ As one scholar notes, Vatican II represented a practical revolution of global Catholicism despite the fact that the bishops only proposed moderate changes in Catholic doctrine and practice. The critical issue in this Catholic revolution was the Church's authority to make "rules" that faithful Catholics were required to obey. ${ }^{80}$

\footnotetext{
${ }^{76}$ Souza, A JUC, 84.

${ }^{77}$ Souza, A JUC, 201.

${ }^{78}$ Greeley, Catholic Revolution, 9.

${ }^{79}$ Ibid.

${ }^{80}$ Ibid., 12-13.
} 
As noted previously, a radical political movement was launched in Brazil during 1962 by Catholic university students. This new party was called Ação Popular (Popular Action or AP) and had immediate electoral success, expanding throughout Brazil at a pace which surprised even the most optimistic militants. National membership was estimated to be between 2000 and 3000 active members. The new party rapidly came to dominate most of Brazil's academic institutions and the National Union of Students. ${ }^{81}$ The AP was open to alliances with other anti-capitalist and anti-imperialist forces, including the Communist Party and Trotskyite groups. Although the new party's beliefs were humanistic, they were also somewhat ill-defined. Ação Popular rejected capitalism and considered the third world's role essential for the defeat of global exploitation. The AP moved away from the purely nationalistic politics and toward class struggle and socialist mobilization. Emphasis was given to implanting the organization among peasants and workers. According to journalist and congressman Marcio Moreira Alves, Ação Popular functioned as an intellectual bridge enabling Catholics cross over toward socialism without entirely losing their faith. ${ }^{82}$

In 1962 the AP released its first ideological statement, entitled Esboço Ideológico (Ideological notes). In March 1963, in Bahia, at a meeting in which top leadership was present, a 16-page foundational ideological document (Documento Base) was developed and $A c ̧ a \tilde{o}$ Popular was formally created. ${ }^{83}$ With the formation of $A c ̧ a \tilde{o}$ Popular the JUC

\footnotetext{
${ }^{81}$ Therry, "Dominant Power Components," 35.

${ }^{82}$ Alves, Grain of Mustard Seed, 120.

${ }^{83}$ Therry, "Dominant Power," 34.
} 
began to diminish as a direct actor in the political arena. Former JUC supporters in university politics simply changed hats and now supported the AP.

Many members of the JUC became involved with the literacy campaign inspired by the educational methods of Paulo Freire and co-sponsored under the auspices of the Catholic Church and the Brazilian government. ${ }^{84}$ The Catholic hierarchy started the aforementioned Base Education Movement, or MEB, as a literacy campaign designed to help educate and raise the social consciousness of the popular classes. Although it was instituted by the bishops, it became effectively controlled by the Catholic Left, principally the JUC, until $1964{ }^{85}$

Luis Edwardo Wanderly recalled strident criticism of JUC by the conservative clergy for its radical politicization in 1962 and 1963. According to Wanderly, during that period of time, progressive and left-leaning clerical advisors gained much influence within the student movement. Within the church hierarchy, a general anxiety about the apparent radicalization of the Catholic student movement resulted in one group of bishops opening an investigation of the JUC. Nevertheless, many of the bishops gradually became more liberal under the pressures of the student movement, military repression and Vatican II. The National Brazilian Bishops Council decided to work for literacy among the deplorably poor of the Brazilian North East, another sign of transition to a more progressive church. ${ }^{86}$

\footnotetext{
${ }^{84}$ Wanderly, interview, September 27, 1988.

${ }^{85}$ Mainwaring, “A JOC,” 42.

${ }^{86}$ Wanderly, interview, September 27, 1988.
} 
Two factors began to modify the role of JUC in university politics: first, a growing desire on the part of the more radical student militants to be independent of church control and second, a growing reaction from the church hierarchy against the political positions being adopted by the JUC. These twin pressures further facilitated the exodus of many Catholic students from the JUC to work directly with the literacy campaign or with the Ação Popular ${ }^{87}$ Jose Roberto Correia Soeiro e Vera Lucia Rossi Soeiro recalls this as a period of fantastic vitality in the midst of a national crisis. The students believed they were fomenting a social revolution in Brazil inspired by influence of the Cuban Revolution. There was a revolutionary social move toward egalitarianism. ${ }^{88}$

The social and political atmosphere in Brazil became increasingly tense in 1963, including the religious tension of a divided church in the Vatican Council. The Brazilian bishops also reacted to the rapid growth of Pentecostalism with a sense of crisis of Catholicism and developed what was known as "emergency plan" in order to attempt to regain its traditionally privileged position in Brazilian society. ${ }^{89}$ Part of the response to this crisis was the increasing involvement of the church in social issues through the MEB literacy and education effort. Increasingly urgent calls were made for agrarian reform which resulted in a growing leadership role of the JUC in left-oriented university politics at the national level. ${ }^{90}$

\footnotetext{
${ }^{87}$ Nagamine, interview. November 3, 1988.

${ }^{88}$ Jose Roberto Correia Soeiro e Vera Lucia Rossi Soeiro, interview, February 11, 1997).

${ }^{89}$ Bruneau, Church in Brazil, 49.

${ }^{90}$ Della Cava, "Catholicism": 32; Souza, A JUC, 201.
} 
Frei Carlos Josaphat started the radical Catholic journal, Brasil Urgente, in São Paulo during this time of popular ferment. The first issue in March of 1963 carried an editorial explaining that the purpose of the Brasil Urgente was the urgent need to struggle for social justice in Brazil. ${ }^{91}$ There was also an article relating the communication between the daughter of Nikita Khruschev (1894-1971), the head of the Soviet Union, and Pope John XXIII during a brief visit to the Vatican. The author was hopeful that this was a sign of the world entering in an era of dialogue and leaving behind the polemic of the Cold War. Another possible sign of increasing disposition to dialogue, according to Brasil Urgente, was beginning of the Second Vatican Council in a climate of intense dialogue between religious leaders from all of the continents and nearly all theological and political perspectives. The author pointed out that the first declaration of the council to the world was that the church was not against any adversary. "It was not anticommunist. It was not anti-protestant. The declaration was an appeal to the world for peace and a denunciation of poverty.",92

There was also an article in Brasil Urgente proposing an alliance between the secular student union, UNE, and the working class. Vinicius Caldeira Brant, the newly elected president of the UNE, spoke with a reporter from Brasil Urgente. Brant, age twenty-two, was a student at the economics department at the university in Belo Horizonte in the Brazilian state of Minas Gerais (according to Luis Edwardo Wanderly, the most radical chapter of the Brazilian JUC) and a former Catholic student leader with

\footnotetext{
${ }^{91}$ Brasil Urgente, March 17, 1963, 3.

92 “Dialogo por cima dos muros,” Brasil Urgente, March 17, 1963, 9.
} 
the JUC. ${ }^{93}$ Brant affirmed that the Brazilian news media was afraid to print clearly the positions of the UNE because of the obvious inclination toward revolution. ${ }^{94}$ The Marxist-leaning Brazilian student union held its annual congress in August $1963 .{ }^{95}$ To the surprise of many, the UNE nominated John XXIII for the Nobel peace prize for his letter on global peace. Although the president of UNE was Vinicius Caldeira Brant, a former Catholic student and member of the Catholic university movement, the JUC issued a clarification distinguishing itself from any political movements. ${ }^{96}$

Frei Carlos wrote an article in June describing accusations against Brasil Urgente by conservative politician Adhemar de Barros, who claimed to uncover a communist conspiracy in Brazil using the Pope's encyclical, Pacem in Terris, as its inspiration and led by Frei Carlos Josaphat himself. The encyclical Pacem in Terris was released in April of 1963, at least in part as a response to the Cuban Missle Crisis of the previous October. Brasil Urgente carried a center spread article with photos about John XXIII and his influence on world peace. Pacem in Terris was the last encyclical written by John XXIII, just two months before he died of cancer. The letter was unique among papal encyclicals in that it was addressed to "all men of good will" rather than to Catholics only. ${ }^{97}$ The letter deals with human rights, the role of the state and the need for greater equity and harmo-

\footnotetext{
${ }^{93}$ Wanderly, interview. September 27, 1988.

94 “UNE: student-people alliance,” Brasil Urgente, March 17, 1963, 17.

${ }^{95}$ Brasil Urgente, August 4, 1963.

96 “Esclarecimiento da JUC do Brasil a Nação,” Brasil Uregente, April 28, 1963, 3.

${ }^{97}$ John XXIII, Encyclical letter "On establishing universal peace in truth, charity and liberty," Pacem in Terris (Vatican Web site, 1963): Http://www.papalencyclicals.net/.
} 
nious relations among nations. Barros accused progressive governor Miguel Arraes of being involved with the Catholic-communist conspiracy. According to Barros, the Bolshevik conspiracy was centered in Sao Paulo. Barros also accused the pope of writing "Peace on Earth" to confuse humanity. ${ }^{98}$

The growing sense of crisis was reflected in the topics presented at the annual National Council meeting of the JUC in the summer of 1963, Father Henrique de Lima Vaz spoke to the Catholic student leaders on such topics as the "Ideological Polarization in Contemporary Culture" and "Christianity and Historical Conscience." "99 The distinction between Christianity as faith or political ideology was discussed. Student leaders attempted to define the Catholic university movement as a space for openness and dialogue, allowing members to choose their own specific ideological and political options. Pacem in Terris, (Peace on earth) was also examined and discussed at this conference. ${ }^{100}$ The encyclical opened the possibility for cooperation between Catholics and members of historical movements of non-Christian inspiration: "Catholics who, in order to achieve some external good, collaborate with unbelievers or with those who through error lack the fullness of faith in Christ, may possibly provide the occasion or even the incentive for their conversion to the truth." 101

98 "Fogo, na igreja e no mundo." Brasil Urgente, June 9, 1963, 2.

99 "Reflexões sobre o sentido do Movimento" working document. 1963. Bidgain Papers.

${ }^{100}$ JUC, “Boletim Informativo,” Boletim Nacional (1963): Bidegain Papers; Beozzo, Cristãos, 4647.

${ }^{101}$ John XXIII, “Pacem in Terris," \#157-8. 
In each issue of Brasil Urgente, the discourse in favor of Christian "social revolution" and against "counter-revolution" was ubiquitous. ${ }^{102}$ There were also frequent rumors of conspiracies. In September the Catholic journal carried an interview with Paulo de Tarso, the Brazilian minister of Education. Tarso quoted the Catholic philosopher, Jacques Maritain, about the need for a Christian social conscience. Tarso expressed his profound confidence in the student youth of Brazil and discussed the need for a "social revolution" and "fundamental reforms" (reformas de base) ${ }^{103} \mathrm{He}$ further observed that social transformation was not just the work of a few small groups but would only be effective with the growing support of a wide base of the people. ${ }^{104}$

At the end of September, the Catholic journal reported that two students from Cuba visited the Brasil Urgente offices to discuss agrarian reform in Cuba as a possible model for Brazil. ${ }^{105}$ Undoubtedly, their presence added fuel to the fires of the conspiratorial imagination of Adhemar de Barros and other conservatives. Despite the problems that Cuban Catholic students were having in Cuba with Castro's regime, the Cuban Revolution was providing inspiration for social revolution to progressive Catholics elsewhere such as in Brazil. In the same issue, a group of Evangelical university students from the U.S. were interviewed for Brasil Urgente. They were

${ }^{102}$ Brasil Urgente, September 1 and September 7, 1963.

${ }^{103}$ Brasil Urgente, September 7, 1963, 10.

${ }^{104}$ Ibid.

${ }^{105}$ Brasil Urgente, September 15, 1963, 8. 
members of the Christian Womens's Association. They were in Brazil to study the "Socio-Economic Revolution in Latin America."

The October 1963 issue of Brasil Urgente carried a full page article with French Catholic Emmanuel Mounier, examining his philosophy of Christian social Personalism and its implications for human rights. ${ }^{107}$ The article enumerated human and social rights and discussed their Judeo-Christian sources and the role of the church and state in preserving such rights. It concluded with a discussion of the importance of fundamental education to raise popular consciousness regarding these fundamental human rights and to guard against the rise of economic or political totalitarianism. ${ }^{108}$

In November, the language of social reform, revolution, counter-revolution and real or imaginary conspiracies continued to appear in the pages of Brasil Urgente culminating with the sudden assassination of U.S. President John F. Kennedy on November 22, 1963 in Dallas, Texas. His assassination was interpreted through the filter of the political crisis in Brazil. The following issue of Brasil Urgente suggested that his death represented a right-wing coup in the United States by forces who were opposed to his efforts to "arrive at an understanding with underdeveloped countries and with coexistence with the Soviet Union." ${ }^{109}$ Kennedy's death increased the intensity of the rhetoric of crisis in Brasil Urgente: "Brazil is living through the longest and gravest political crisis in all of the history of the republic... the people want reforms. They

\footnotetext{
${ }^{106}$ Ibid., 10.

${ }^{107}$ Brasil Urgente, October 27, 1963, 12.

${ }^{108}$ Ibid., 12.
} 
demand reforms. They are in the streets crying out for fundamental reforms (reformas de base). They want an agrarian reform, urban reform, constitutional reform and university reform. The people want a revolution not a coup. The word of order of the people condemns any attempt at coups, and buries the criminal neo-fascist Right of Brazil: Reforms yes! Coup de etat, no!" ${ }^{110}$ The discourse of political reform and social revolution had become shrill.

Frei Carlos apparently went too far in his unrelenting criticism of the existing order in Brazil and in December 1963 was ordered by his Dominican superiors to leave Brazil. The editorial directors of Brasil Urgente explained the departure into exile of Frei Carlos in terms that were severely critical of the church hierarchy. According to the editorial, the Catholic Church (in the middle of Vatican II) had yielded to intimidation and had backed off in the face of the power of money and political prestige. According to the author, Dorian Jorge Freire, the exile of Frei Carlos was "extremely discouraging... the Dominican theologian became hated because of his preaching of Christianity. He was intolerable for the powerful and had the bravery of an apostle." 111 According to Freire, Josaphat was ordered to leave Brazil by the Dominican Order because he was causing too much trouble. The author continued to opine that removal and expulsion of Frei Carlos represented "a sad capitulation" of the Dominicans in the face of organized pressure. The new director of Brasil Urgente was Jose Reinaldo, who was described by Freire as "representative of the functionaries." Frei Carlos was not understood by "comfortable

109 “Morte de Kennedy foi Golpe de Estado" Brasil Urgente, December 1, 1963, 2. 
Christians. $" 112$ The strains within various sectors of the Catholic Church, as well as within Brazilian society at large, seemed to have reached a breaking point. Crisis and Military Reaction: 1964-1966.

As Brazil entered 1964, the tension between opposing political orientations reached an irreconcilable impasse. Violent disturbances occurred in the streets of Belo Horizonte between members of Catholic Action and conservative Catholic Integralists. ${ }^{113}$ At a massive demonstration of public support in Rio de Janeiro in March, President Goulart urgently called for needed reforms. In response, more than a million people turned out for a conservative counter-demonstration four days later in São Paulo. The sense of political stalemate and crisis had reached a breaking point. ${ }^{114}$

On April 1, 1964, the military finally carried out a coup d'etat, which it euphemistically called a "revolution," in order to end the political crisis. ${ }^{115}$ The journal Brasil Urgente in São Paulo was closed down, the offices of the UNE in Rio were ransacked, and numerous militants of the JUC and MEB (the Base Education Movement for literacy) were imprisoned. Catholics turned on one another as conservatives denounced com-

${ }^{110}$ Ibid.

111 “Frei Carlos foi Exiliado,” Brasil Urgente, December 22, 1963, 5.

${ }^{112}$ Ibid.

${ }^{113}$ Catholic integralism was a corporatist political philosopy that before World War II was in vogue and may be considered proto-fascist in some cases. It fell out of favor within Catholic Action in the postwar period: Robert M. Levine, Father of the Poor? Vargas and His Era (Cambridge: Cambridge University Press, 1998).

${ }^{114}$ Da Veiga, "Reform of the Brazilian University," 2, 21. 
munist infiltration within the Dominican order and helped the police arrest priests in the Dominican convent. ${ }^{116}$

At the peak of radicalization and rapid growth of the Catholic student movement, democracy in Brazil was suspended in favor of military rule. The military had become convinced the existence of a pending communist social revolution and had acted preemptively to forestall such a possibility. This period of military dictatorship coincided with one of the most profound periods of change in the Brazilian Catholic Church, which eventually became a primary source of opposition to the military regime, and for a time provided the only voice for human rights and the rights of the poor in Brazil. ${ }^{117}$

Although the bishops initially provided moral support for the military coup of April 1964, it was nevertheless the beginning of an inevitable slide toward conflict and rupture in the historical relationship between the Brazilian church and the Brazilian state. Kenneth Serbin notes that "cross and sword" entered into conflict in $1964 .{ }^{118}$ While the church of the Second Vatican Council stressed social justice, the Brazilian military fought communism and subversion. ${ }^{119}$ During the period from 1964 to 1966 the Brazilian Bishops National Council attempted to restrain Catholic political radicalism and keep open channels of dialogue with the military regime. Nevertheless, growing human rights

\footnotetext{
${ }^{115}$ Alistair Hennessy, "University Students in National Politics," The Politics of Conformity in Latin America, Ed. Claudio Veliz (London and Oxford: Oxford University Press, 1970) 149.

${ }^{116}$ Beozzo, Cristãos, 49.

${ }^{117}$ Mainwaring, Catholic Church, 104.

${ }^{118}$ Serbin, Secret Dialogues, 221.

${ }^{119}$ Serbin, Secret Dialogues, 221.
} 
abuses and especially abuses against Catholic priests and lay workers had begun to force the Church into a position of firm opposition to the State by $1969 .{ }^{120}$

The suspension of democracy and the imposition of military rule brought intense repression of student movements, both Marxist and Catholic alike. The headquarters of the National Student Union (UNE) in Rio de Janeiro was set on fire in April of 1964. The repression of student leaders began almost immediately afterwards. Isa Guerra, a former member of the JUC, and her fiancée Cosme, were arrested by the police in June and detained for months. Isa was a social worker and had been one of the chief organizers of the Ministry of Education's popular education program under Goulart. When the military coup occurred she had just spent a year in a favela working on behalf of prostitutes. Although she herself was not tortured (the torture of women would come later) she was forced to listen for several months to the groans and screams of her fiancée and other student militants who were being tortured. ${ }^{121}$ One of the first confirmed cases of torture involved a frail student called Dorremi at Rio's agricultural school, who carried scars from torture from electrical shocks. He was arrested by the political police along with several dozen other students who were watching a film just before going to bed on May 26, 1964. ${ }^{122}$ Incidents such as these caused the student leadership UNE to become ever more

${ }^{120}$ Ibid.

${ }^{121}$ Alves, Grain of Mustard Seed, 118-119.

${ }^{122}$ The political police was called Departamento de Ordem Politica e Social, or DOPS. DOPS was a state political police force in the state of Rio de Janeiro. See Thomas E. Skidmore, The Politics of Military Rule in Brazil 1964-85 (Oxford: Oxford University Press, 1988), 17, 25 and 26. 
radicalized. The student movement eventually opted for popular insurrectionary struggle against the military regime. ${ }^{123}$

The military regime began to crack down on the political sphere. A former member the JUC, Joseph Nagamine, recalled that the various left-wing movements could not maintain their unity in the face of the military coup of $1964 .^{124}$ Another former student militant, José Juliano de Carvalho Filho, recalled that with the beginning of the military regime in 1964, political action was repressed and an even greater and more violent repression came in 1968 from the military government. ${ }^{125}$ Walter Borelli also recalled that after the military intervention in 1964 there was very little room for political activity on the university campus. ${ }^{126}$

In 1965, the military regime continued to repress the JUC and the Ação Popular. This led to disorganization in the activities of both entities and paralysis of political, cultural and social action. After the initial phase in which spending time in prison was a cause for pride among some jucistas, the military repression began to take its toll through the intimidation, the interruption of studies, the loss of employment, interrogations and the constant sense of insecurity. In the middle of these political pressures, the church hierarchy attempted to regain control of the student movement. Many of the more radical clerical advisors, such as Padre Sena and Padre Almeri Bezerra of the JUC, who had en-

${ }^{123}$ Souza, A JUC, 84.

${ }^{124}$ Nagamine interview. November 3, 1988.

${ }^{125}$ Elisa de Carvalho and José Juliano de Carvalho Filho, interview. Programa de Documentação Oral (Säo Paulo, Brazil: C.E.D.I.C., January 23, 1990).

${ }^{126}$ Borelli, interview. January 26, 1990. 
couraged the radicalization of the movement, were forced to leave the country and go into exile. Almost all of the other advisors were removed from their positions with the JUC by the bishops because of the general distrust of the bishops toward the movement. ${ }^{127}$

Marcio Moreira Alves was a liberal reporter for the Rio de Janeiro newspaper, Correio da Manhã (Morning mail), at the time of the military takeover in 1964. In his capacity with the press, he spent extended periods of time visiting imprisoned Catholic student militants, many of whom were tortured. Although he was a non-practicing Catholic, the courageous political stand of these Catholic militants caused him to rethink his own faith and to make a deeper level of religious commitment. Alves was later elected to Congress were he took a principled stand in opposition to the military. In his 1970s book, A Grain of Mustard Seed, he described his conversion to faith and affirmed that it was the experience of witnessing the torture of Catholic students that caused him to re-examine his cynicism toward Catholicism and living Chritian faith. ${ }^{128}$

Despite his admiration and eventual conversion, Alves considered the students to be politically naïve in the early phase of the resistance to the military. He recalled that some students treated police vigilance as a youthful sport before 1968, an attitude which was later to claim a high price, when students grew overconfident with disastrous results. ${ }^{129}$ A prominent historian of Brazil agreed with the assessment of Moreira Alves that the Catholic students of the JUC were idealistic political amateurs. ${ }^{130}$

\footnotetext{
${ }^{127}$ Beozzo, Cristãos, 50.

${ }^{128}$ Alves, Grain of Mustard Seed, 96-97, 146.

${ }^{129}$ Ibid., 125.

${ }^{130}$ Skidmore, Politics of Military 1964-85, 16.
} 
The provocative stance of the student movements and the alliance between Catholic and communist students placed Brazil's bishops in an extremely awkward position just as they were attempting to negotiate their way through the vertiginous changes happening in Rome at the Second Vatican Council. In September of 1965, a group of Brazilian bishops participating in the Second Vatican Council in Rome met to discuss what to do about the increasing radicalization of Brazilian Catholic Action and in particular the university movement. After several meetings in Rome and extensive discussions they decided to develop a new set of statutes for Brazilian Catholic Action in the light of the papal document, Lumen Gentium. ${ }^{131}$ In this discussion, several bishops criticized the politicization of the JUC. Dom Cândido Padim, national chaplain of the JUC, responded in defense of the students by pointing out the inherently contradictory nature of the mission the bishops had given the JUC. On the one hand, the bishops had demanded of the students that they attempt to sacralize secular society. On the other hand, they wanted to impede the same students and lay workers from effectively realizing their goals as lay people. $^{132}$

By the end of the Council, the Brazilian bishops had a new five-year pastoral plan for Brazilian Catholic Action. Since these plans were developed without any consultation with representatives of Catholic Action or the youth or student movements, and over the objections of Dom Padim, they indicated a rupture between the lay movements and the

${ }^{131}$ Paul VI, Lumen Gentium, Dogmatic Constitution on Th e Church (Rome: November 21, 1964), Http://www.vatican.va/archive/hist_councils/ii_vatican_council/documents/vat-ii_const_19641121_lumengentium_en.html.

\footnotetext{
${ }^{132}$ Beozzo, Cristãos, 50.
} 
Catholic hierarchy. In January 1966, Dom Cândido Padim was removed as the national advisor to the JUC and moved to bishopric near Sao Paulo and no one was named to replace him. ${ }^{133}$

In 1966, the Central Commission of the Brazilian National Bishops Conference, chaired by Dom Vicente Scherer, met in Rio de Janeiro. After some discussion, Scherer proposed that some of the movements of Catholic Action including JUC be restructured on a regional rather than a national basis to allow the bishops to maintain closer oversight. Shortly after, Dom Scherer convoked the various movements of Catholic Action to a meeting. An appeal written collectively by all of the specialized Catholic Action movements was of no avail. Several more appeals were written by the JUC. Finally, the JUC announced that it no longer considered itself part of Catholic Action nor part of any other form of organization that defined itself as an extension of the apostolic hierarchy. The decision to separate itself from Catholic Action basically represented an act of rebellion against the church hierarchy. Dom Scherer expressed his regret at their decision to separate themselves from Catholic Action and invited them to reconsider. He reminded them of the definition of Catholic Action given by Pius XI in $1935 .{ }^{134}$ By November 1966, the National Secretariat of the Lay Apostolate communicated the dissolution of the specialized student teams including the JUC and the secondary school JEC. ${ }^{135}$ As one scholar has noted, the actions of the hierarchy drove some these young people away

\footnotetext{
${ }^{133}$ Ibid., 51.

134 "The Sharing (or participation) of the Laity in the apostolate of the hierarchy." Pius XI, "Quamvis Nostra de Actione Catholica," Encyclical (Rome: Vatican, 1935) 160-16; Anderson, Pope Pius XI: 69 .
} 
from all organized religion. Others lost faith in the authority of clerical hierarchy and either turned back to the scriptures for guidance or lost their faith entirely and turned to secular political ideologies. ${ }^{136}$

Under pressure by the military regime, the leadership of Catholic-inspired, $A c ̧ a \tilde{o}$ Popular, decided to declare itself Maoist in ideology in 1966, despite the fact that there were already numerous existing Marxist-Leninist parties of Soviet, Cuban and Chinese persuasions. This choice effectively removed the bridge between the Catholic Left and the socialists, and led to the conflict and disarray within the AP. ${ }^{137}$ Post-JUC: Persecution and Resistance1967-68.

The National Council of the JUC met to discuss whether or not they should attempt to continue as a "church" group, given that most of their organized activity was now focused in the political and social dimensions. The old discussion regarding the difference between Christian faith and ideology continued, and many of the members of the JUC came to consensus that Christianity should not be turned into a political ideology. After two years without spiritual advisors, the entire movement felt the need to return to some kind of theological reflection. A priest named Frei Bernardo Catao offered to help informally as a friend during the regional meeting in Sao Paulo. ${ }^{138}$

The military regime began to harden its repression with increasing numbers of disappearances and tortures. Joseph Nagamine recalled later that it was this hardening of

\footnotetext{
${ }^{135}$ Beozzo, Cristãos, 52.

${ }^{136}$ De Kadt, "Religion,” 211.

${ }^{137}$ Alves, Grain of Mustard Seed, 121.
} 
the military regime in 1967 and 1968 which finally forced the church to begin to oppose the government. ${ }^{139}$ Other former members of the Catholic student movement experienced repression during this final phase of the ideological development of the JUC. Padre Enzo Campoes Gusso was persecuted by the military for his opposition to the dictatorship. Carlos Alberto Libanio Christo, also known as Frei Betto, had been arrested, tortured, and imprisoned for 15 days in June of 1964. At the time, he had been traveling around Brazil working extensively with both the JUC and with communists. ${ }^{140}$ Frei Betto was deeply influenced by the Cuban Revolution. After he was arrested and tortured, he became a Dominican priest and began to work clandestinely on the border between Brazil and Uruguay helping Brazilians escape from Brazil. Eventually the police caught up with him again. He was imprisoned for four more years along with twelve other Dominican priests. ${ }^{141}$ Although arrests and torture continued into the early 1970 s against all sectors of Brazilian civil society, the violence against former Catholic students culminated on May 26 of 1969, with the torture and murder of Dom Helder Câmara's young assistant, Father Henrique Pereira Neto, a priest who had been the advisor to the Catholic student movements in Recife. ${ }^{142}$

After 1966, the JUC no longer existed in Brazil as a student lay-organization affiliated with the Catholic Church. It is ironic that shortly after the closure of the Second

\footnotetext{
${ }^{138}$ Beozzo, Cristãos, 53.

${ }^{139}$ Nagamine, interview, October 14, 1988.

${ }^{140}$ Betto, interview, July 8, 1997.

${ }^{141}$ Ibid.

${ }^{142}$ Alves, Grain of Mustard Seed,159.
} 
Vatican Council with much of the transnational Catholic hierarchy apparently willing to embrace progressive views of social justice issues, economic equity and democracy, that the bishops would bring a pioneering social force such as the JUC to an end. It is also ironic that just as the Brazilian church hierarchy began to move into a stance of moral opposition to the Brazilian military regime, they also sought to reign in the radical Catholic student movement. What is to account for the demise of the Juventude Catolica Universitaria at the precise moment that Catholic Church appeared to be opening up to a more progressive vision of faith? A further bit of irony is that the closure of the JUC came almost simultaneously with the first stirrings of liberation theology in Latin America. $^{143}$

The answer is found in the very success of the JUC. As early as 1922, Pope Pius was calling for Catholic lay people to carry Catholic beliefs and values across the sacredsecular cultural divide to influence secular and professional spheres. ${ }^{144}$ The whole concept behind Catholic Action was the work of Catholic lay people to incarnate Catholic social teaching and Catholic values in their respective social classes and professional spheres. Catholic Action attempted to influence all secular spheres of society: women, men, youth, academia, workers, rural agricultural communities, elementary schools and high schools through the grass-roots mobilization of Catholic lay people. Specialized Catholic Action, influenced by the French Catholic philosophy, was especially distin-

\footnotetext{
${ }^{143}$ As noted earlier, the Brazilian JUC came to an end in early 1967. The Cuban student movement was mostly driven into exile by 1963 . The Catholic university movement in Spain came to an end in 1966. For Spain see Monteiro Garcia, La Acción Católica, 56.

${ }^{144}$ Pope Pius XI, Encyclical letter “Ubi Arcano Dei Concilio,” (Vatican Web site, 1922), \#58.
} 
guished by its overriding vision to encourage catholic youths to become militant crusading missionaries in their respective professions and secular occupations and demographic groups.

The Catholic hierarchy was not prepared for the unintended consequences of transculturation. Cuban scholar Fernando Ortiz coined the term "transculturation" rather than "acculturation" in order to suggest the idea that cross-cultural engagement flows in a bi-directional fashion. ${ }^{145}$ As the militants of the JUC began to engage fully with other student activists and to enter into dialogue with sectors of the university adhering to dependency theory, modern sociology and Marxist political theory, not only did they bring Catholic thinking to bear on issues of economic and social justice, they also respectfully listened to Marxist and socialist political thinking on these same issues. With the encouragement of thinkers and activists such as Emmanuel Mounier and progressive clerical advisors such as Father Romeu Dale and Monseignor Cândido Padim, young Catholic intellectuals in Brazil began to talk with communists, Marxists and student members of secular ideologies about the social inequities in Brazil. It was not long before the JUC began to make common cause with the secular and radical student groups, much to the chagrin of the Catholic bishops. As the bishops originally intended, some secular young people and Brazilian Marxists came to faith through the influence of these Catholic militants, such as was the case of Marcio Moreira Alves. Alves, who at first was highly critical of Catholicism, was profoundly influenced by deeply committed members of the JUC 1995) 5.

\footnotetext{
${ }^{145}$ Fernando Ortiz, Cuban Counterpoint: Tobacco and Sugar (London: Duke University Press,
} 
who were being persecuted and often even tortured by the military government for their political commitment. ${ }^{146}$ Nevertheless, the Church grew uncomfortable with contrary cases such as Frei Betto who closely associated with communists and sought to emulate Che Guevara. Many other Catholic students participated in the formation of the radical Ação Popular and in the process became committed to Marxist political struggle and even armed insurrection. Devout young Catholics moved through progressive steps toward embracing some form of Marxism as a theoretical framework for social and economic analysis and practical political engagement. ${ }^{147}$

The bishops wanted to use the students to project Catholic social values into secular society. Indeed the student militants did project Catholic values into the student movement, but in the process, their own traditional values changed. In the course of the early 1960s, Brazilian Catholic students experienced a significant paradigm shift--indeed, one might be tempted to say a "revolution"--from the traditional Catholic values of respect for authority, the patriarchal family, prayer and private devotion to a whole new set of spiritual values drawn from the Sermon on the Mount, the liberating example of Jesus and the social teaching of the church. The values in 1964 were no longer the same values of the early 1950s.

The Catholic student movement succeeded in its task of incarnating a new set of Christian values in the political, academic and social arenas in Brazil after a half of a century of activism. Thousands of bright young Catholics were trained to apply their Catholic ethical criteria to discern unjust social structures and to act in practical ways to change

${ }^{146}$ Alves, Grain of Mustard Seed, 145-146. 
Brazilian society. In the tense context of Cold War and the Cuban Revolution, the Catholic student movement went well beyond the evangelizing work originally envisioned by the Catholic bishops and began to challenge economic and social structures and increasingly forced the bishops to choose between a preferential option for Brazil's poor and disadvantaged or continued alliance with the status quo. It seems clear that the Catholic student movement in Brazil was successful in challenging the barriers between faith and politics, the sacred and the secular and in challenging the hegemonic class structure of Brazil to its own eventual detriment.

Like many countries in Latin America that have traditionally vacillated between reform and revolution, Brazil also gyrated between these options from 1961 to 1964 but eventually settled into reaction and military repression with democratic reforms put on hold until the mid-1980s. During the Cold War between the United States and the Soviet Union, from 1956 to 1966, the young Catholic university movement pioneered serious engagement with the social teaching of the church, the opening of the church to the modern world in Vatican II, and many aspects of liberation theology. ${ }^{148}$

The Catholic Left exercised a profound influence on the Brazilian church in helping create a new vision of faith, a faith that is connected to commitment to social change. Many of the concepts that later were systematized in the theology of liberation were practiced for the first time in the Catholic Left. From the ranks of the JUC emerged many lay

${ }^{147}$ Souza, $A J U C, 23,25$.

${ }^{148}$ Christian Smith, The Emergence of Liberation Theology: Radical Religion and Social Movement Theory (Chicago: The University of Chicago Press, 1991), 192; Bidegain, "From Catholic Action to Liberation," 18 and 21. 
leaders that two decades later continued to maintain key positions of leadership within the church. ${ }^{149}$

${ }^{149}$ Scott Mainwaring, “A JOC,” 42. 


\section{CHAPTER VI}

\section{THE INFLUENCE OF THE CATHOLIC UNIVERSITY MOVEMENT}

"Conclusion: politics has a close dialectical relation with religion. Their mutual centrality is not surprising. Politics, after all, deals at the most general level with the organizing principles and symbols of the entire society. Religion, in turn, provides values which give meaning to human life, placing any given set of social or political events in a broader framework of significance. In Latin America today, religion is a problem for politics and politics no less a problem for religion."

My dissertation has examined the Catholic university student movements from the 1920 s through the 1960s in several different countries and continents. The question yet remains unanswered; what was the social significance of the Catholic university movement? What was its overall impact? Did the Catholic university movements exert more influence on the church or on their respective societies? Or, on the contrary, in what ways were the Catholic university movements influenced in turn by the unique social problems and political upheavals in their respective societies?

John A. Coleman draws together the Sociology of Religion of Max Weber with the concept of a "concrete historical ideal" articulated by French philosopher Jacques Maritain to develop a theoretical framework for understanding how a church might mobilize its members for a world transformative mission. Drawing upon Max Weber's analysis of the necessary conditions for a "Church with a worldly vocation," Coleman identifies three essential elements for the mobilization of a religious movement that is capable of producing sustained social and cultural change. ${ }^{2}$

\footnotetext{
${ }^{1}$ Daniel H. Levine, Churches and Politics in Latin America (Beverly Hills, CA: Sage Publications, 1980), 35.

${ }^{2}$ H.H. Gerth and C Wright Mills, eds., From Max Weber: Essays in Sociology (Oxford: Oxford University Press, 1958), 325.
} 
First, there must be an underlying and irresolvable tension between a compelling vision for an ideal social order based on mutuality, community and justice, and the need to accommodate such a vision to the mundane world as it exists. Such a religious movement must not take flight from the world, nor can it fully accommodate itself with the world. It must be in the world but stand in prophetic opposition to it as it points to a potential higher order of society (in traditional Christian thinking this is represented as the "kingdom of God on earth"). ${ }^{3}$

Second, a church with a worldly vocation must develop a pastoral strategy to effectively mobilize its constituency into a high level of commitment to view the world and their work as an arena of highest priority for religious action. It is not sufficient for the religious hierarchy to make moral pronouncements regarding the social order. The laity must be solidly convinced to act decisively and consistently to promote religious values within the secular spheres of society. The religious hierarchy must elicit this commitment from the laity and empower them to carry out their 'worldly vocation' without overriding or limiting their autonomy. The third and final condition is the effective and sustained mobilization of lay energies around practical action to influence the social order by infusing religious values into the "secular realm" in the attempt to move the existing social order towards a "concrete historical ideal."4

Here, Coleman drew from the philosophy of Jacques Maritain (1882 - 1973) who was a French philosopher raised as a Protestant and converted to Catholicism in 1906. In his seminal work, Integral Humanism, Maritain proposed the concept of a "concrete his-

\footnotetext{
${ }^{3}$ Coleman, Strategic Theology, 39.
} 
torical ideal" as a realistic alternative to the forever unattainable ideal of utopia. ${ }^{5}$ Maritain's concrete historical ideal is a specific social possibility in any given historical epoch, with corresponding and historically determined limits and potentialities. Coleman pointed to Alexis de Tocqueville's study of democracy in the United States in the nineteenth century as an example of the delineation of a concrete historical ideal. ${ }^{6}$

According to Maritain, utopia is something that is constructed ens rationis (a "being of reason") ahistorically and conforming to an absolute social and political ideal. As an alternative, Maritain proposes a concrete historical ideal which is not abstract, but which represents an ideal essence which is historically achievable, but with obvious limitations and imperfections. Maritain intends that the concrete historical ideal be "an essence capable of existing in a given historical climate" with a relative level of social and political perfection that may serve as a "frame-work and a rough draft which may later be determinative of a future reality.", This would create a possibility for a "Christian philosophy of culture to prepare future temporal realizations by exempting it from the need to pass through a utopian phase." ${ }^{8}$

Coleman takes Maritain's concept of the concrete historical ideal, and places it in conjunction with Weber's idea of a "church with a worldly vocation" in order to deter-

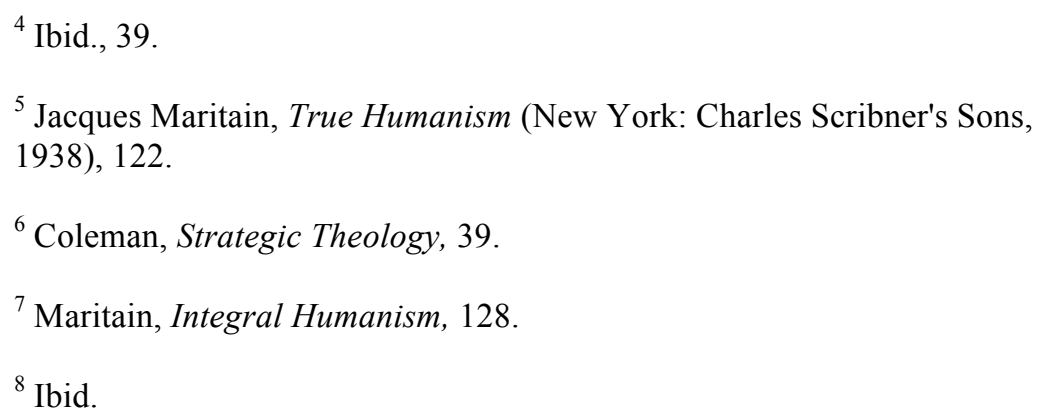


mine what factors may be necessary for such a church to effectively pursue a "worldtransforming mission." 9 Such a transformative mission is to be carried out by the influence of the laity in secular spheres of society at the grass-roots level. This social transformation is accomplished through the incarnational and prophetic action of highly committed lay people in their respective secular venues of work, community and social class. $^{10}$

Weber used the term "acosmic love," as a key characteristic of religions of salvation, or religions of brotherly love. Acosmic love is drawn from a difficult to translate German word, Liebesakosmismus, which can also be roughly rendered "world-denying love" and is exemplified by the examples of the Buddha, Jesus of Nazareth and St. Francis of Assis, and more recently in Mohandas Gandhi, Martin Luther King, Jr. and Mother Teresa. ${ }^{11}$ Acosmic love is an impersonal, universal love that is extended beyond the tribe, family or kinship group to all of humanity and all of creation (and ultimately even to enemies) and provides the theological underpinnings of an "ethic of brotherly love."12 The ethic of brotherly love arose in many of the prophetic movements that resulted in the great world religions in the axial period of the first millennium before Christ. The Catholic Action impulse from the 1920s through the middle of the 1960s was ostensibly to carry "Catholic" social values into the secular sphere. At a deeper level, the mission of spe-

\footnotetext{
${ }^{9}$ Coleman, Strategic Theology, 39.

${ }^{10}$ Ibid.

${ }^{11}$ Robert Bellah, "Max Weber and World-Denying love: A look at the Historical Sociology of Religion," Journal of the American Academy of Religion, Vol. 67, No. 2 (June 1999), 278.

${ }^{12}$ H.H. Gerth and C Wright Mills, eds., From Max Weber: Essays in Sociology (Oxford: Oxford University Press, 1958), 329.
} 
cialized Catholic Action was to inject the ethic of universal brotherly love into the "Iron Cage" of Western modernity which had developed an unloving and impersonal ethic of instrumental rationality in every sphere, but especially in the economic and political spheres. ${ }^{13}$ One of the great dilemmas of the church in the twentieth century was how to accomplish the social humanization of Western capitalistic society without succumbing to Marxist totalitarianism.

In order to analyze the significance of the Catholic student movements that developed in the twentieth century in Europe, Quebec and eventually in Brazil and Cuba, one must consider a series of dichotomies relating to the role of the church in society. These factors include the sacred-secular duality, the clergy-layperson distinction, and the perennial tension between religion and politics. Within the area of religion and politics, there are other contrasting elements such as the tension between faith and ideology, and between progressive and conservative theological and political currents within the Catholic Church. ${ }^{14}$

In addition to these issues, in a comparative study such as this, there are also contrasting cases. In the first place, this dissertation has analyzed two different sources of lay and student mobilization within modern Catholicism: general Catholic action with its origins in Fascist Italy, and specialized Catholic Action originating in a Franco-Belgian

${ }^{13}$ The "Iron Cage" is a reference to Weber's description of the dilemma of modern man, trapped in an ever increasing "rational bureaucracy" that was ever more efficient at the same time as it was alienating. Max Weber, The Protestant Ethic and the Spirit of Capitalism, trans. Talcott Parsons (New York: Scribner's, 1958) 123.

${ }^{14}$ Eva Bellin, "Faith in Politics: New Trends in the Study of Religion and Politics," World Politics 60.2 (Jan 2008): 332; Peter L. Berger, ed., The Desecularization of the World: Resurgent Religion and World Politics (Grand Rapids, MI: Eerdmans Publishing Co., 1999), 15. 
working class context. Both of these forms of Catholic lay movements radiated out from Europe in a missionary thrust that extended to Latin America with different effects and results. ${ }^{15}$ Specifically, this study has examined the influence of Catholic Action student movements in Brazil and Cuba and their various social and political roles in a period of turbulent change in their respective countries.

Overall, global Catholicism, despite local, regional and ideological differences, harkened back to a common medieval heritage of hegemonic theocratic influence in a feudal civilization. ${ }^{16}$ Under a unique set of historical factors in the medieval period, the church achieved a relatively unified Christian civilization under the leadership of the Pope. Medieval Catholicism provided a so-called "Sacred Canopy" as a moral consensus or "plausibility structure" for the emerging Western Civilization. ${ }^{17}$ According to the classic sociological analysis of Christian social teaching by Ernst Troeltsch early in the twentieth century, the fundamental basis of the medieval Catholic ethic and the corresponding ecclesiastical theocracy lasted into the modern era and the Catholicism of the early twentieth century looked back upon the "social reality of the Middle Ages, in its main features, as the expression of reason." with secular modernity. ${ }^{19}$

${ }^{15}$ Bidegain, Participación y Protagonismo, 41-47.

${ }^{16}$ Ernst Troeltsch, The Social Teaching of the Christian Churches, vol. 1, trans. Olive Wyon (Louisville, London: Westminster John Knox Press, 1931, reprint 1992), 246; Casanova, Public Religions, 61.

\footnotetext{
${ }^{17}$ Peter L. Berger, The Sacred Canopy: Elements of a Sociological Theory of Religion (New York: Doubleday and Co., Inc., 1967), 17.

${ }^{18}$ Troeltsch, Social Teaching, vol. 1, 270.
} 
Since the fragmentation of the "Sacred Canopy" or what Max Weber called the "disenchantment" of society, church and society have faced an intractable problem. ${ }^{20}$ For the church, the problem is how to offer normative moral influence to secularized society. For society, the problem has been how to construct a social consensus around a fundamental ethical code without an established church or religion. This is the "sacred/secular" dichotomy that the Catholic Church attempted to resolve in the twentieth century by encouraging the growth of the lay-people's movement, Catholic Action, and the corresponding student movements within Catholic Action.

Closed Catholicism, 1920-1960

The most active period of Catholic Action was from the early 1920s through the mid-1960s. The period of Catholic activism corresponds to the rise of the Catholic workers movement as well as the student and university movements. One scholar defined the Catholicism of Europe from 1920 through 1960 as 'closed' Catholicism. According to John Henry Whyte, this forty year-period of closed Catholicism had three components: the existence of Catholic political parties; the existence of Catholic social organizations; and pervasive political guidance of the clergy. ${ }^{21}$ In continental Europe, the origins of closed Catholicism lay in the nineteenth century when continental liberals became increasingly militant and anti-clerical resulting in a assumption of a defensive posture by Catholics in a pan-conservative alliance (including Monarchists). When the disad-

\footnotetext{
${ }^{19}$ Alvarez Junco, "Formation of Spanish Identity," 26, 34.

${ }^{20}$ Berger, Sacred Canopy, 17.

${ }^{21}$ John Henry Whyte, Catholics in Western Democracies: A Study in Political Behaviour (Dublin: Gill and Macmillan, 1981), 125.
} 
vantages to this alliance with the ancién regime royalists became obvious, Catholics tried to distance themselves by organizing themselves exclusively along confessional lines. ${ }^{22}$

Since religion was no longer allowed to impose itself upon the secular sphere in the modern world, how was the church to influence secular society with sacred values? The Protestant churches eventually solved this dilemma by participating in a religious "free market" where each denomination was a producer of spiritual goods and services and the church member or attender was a consumer of religious products. ${ }^{23}$ The upside was that intense competition forced Protestant and Evangelical churches to continually upgrade their performance (in providing a religious 'product' or service) in such a way as to attract religious consumers. ${ }^{24}$ In the second half of the twentieth century, Pentecostal, Independent and Evangelical churches outperformed the historical mainline Protestant churches leading to the rapid growth of the former and precipitous decline of the later. ${ }^{25}$ The downside is that the religious faithful were often turned into consumers of religious products rotating through the revolving door of multiple churches rather than committed disciples of faith. ${ }^{26}$

${ }^{22}$ Whyte, Catholics in Western Democracies, 125.

${ }^{23}$ Chesnut, Competitive Spirits, 10; Christian Smith and Joshua Prokopy, eds., Latin American Religion in Motion (New York: Routledge, 1999), 2.

${ }^{24}$ See books on the religious free market. Andrew Chesnut on Brazil and Rodney Stark.

${ }^{25}$ David Martin, Tongues of Fire: The Explosion of Protestantism in Latin America (Cambridge, MA: Blackwell, 1990), 49.

${ }^{26}$ Chesnut, Competitive Spirits, 1. 
It would be an understatement to say that the Catholic Church has never been very comfortable with liberal capitalism. ${ }^{27}$ The Medieval Catholic ideal was an organic collective life based on the monastic ideal of love. Importance was attached to personal relationships and a sense of solidarity and community feeling, "expressed in mutual help and interdependence in which all of the people living in one place became a kind of united body, based on a spirit of mutual protection and mutual service. ${ }^{28}$ During the late nineteenth century, Pius IX condemned liberalism and representative democracy as modern heresies. ${ }^{29}$ It was only with the rise of Marxism and working class social movements in the twentieth century that the papacy began to overcome its reluctance to embrace modern liberal capitalism in face of the greater perceived threat of anti-clerical socialism. Nevertheless, even as late as the 1960 s, the church sought to chart a third way of some kind of humanistic socialism as an alternative to both liberal capitalism and atheistic communism. $^{30}$

Despite the Catholicism's critical stance toward Protestant and capitalistic western society, the church was forced to adapt to some aspects of Protestantism in order to avoid losing even larger numbers of adherents to Protestant competition. The apparent answer to the "sacred/secular" division in the 1920 s was conceived by Pius XI, to be the lay-led and lay-mobilized Catholic Action and a variety of lay-oriented movements within Catholic Action including the Catholic student movements. One might view this de-

\footnotetext{
${ }^{27}$ See the papel encyclicals Rerum Novarum (1891) and Quadreggissmo Ano (1931).

${ }^{28}$ Troeltsch, Social Teaching, 249.

${ }^{29}$ Lakeland, Liberation of the Laity, 18.
} 
velopment within Catholicism as an attempt to bring some degree of accommodation with modernity within Catholicism without serious departure from Catholic tradition and without embracing the Enlightenment. ${ }^{31}$ Catholicism has long been able to incorporate numerous and often opposing tendencies within its fold without the more extreme forms of division and fragmentation that has characterized Protestantism. ${ }^{32}$

In the middle of the twentieth century a new theology (known as the "nouvelle théologie") arose among a group of French Jesuits, Dominicans and transcendental Thomists which emphasized that there is only one history, that the church is a worldly reality and the desire to know God is a natural expression of the human being as created by God. These theologians, the previously mentioned Marc Chenu, Yves Congar, Henri de Lubac, and Jean Danielou, collectively arrived at the conclusion that the "humanization of the world, whether conducted by a Christian, Buddhist, or an atheist is the world growing into the plan of God. ${ }^{33}$ Yves Congar was particularly noted for his theological work on the importance of the laity. He described the layperson as one for whom the substance of things in themselves is real and interesting, or in his words "...the sacredness of the autonomy of the secular. ${ }^{\prime 34}$ The new theology's emphasis on the layperson and on the importance of mundane or everyday reality was congruent with the pragmatic emphasis on

${ }^{30}$ Claude Geffré and Jean-Pierre Jossua, eds., The Debate on Modernity (London: SCM Press, 1992) 15; Curtis, "Modernity": 76.

${ }^{31}$ Clark and Kaiser, Culture Wars, 44.

${ }^{32}$ Troeltsch, Social Teaching, vol 1, 355-8.

${ }^{33}$ See footnote \#66 on page 53; Lakeland, Liberation of the Laity, 151.

${ }^{34}$ Lakeland, Liberation of the Laity, 156. 
praxis and concrete action among young students and workers within specialized Catholic Action. ${ }^{35}$

As Coleman points out, Christian social teaching is not a defined dogma, but represents an evolving body of thinking which reflects the evolving social process. Catholic Action was an attempt by the Catholic Church to launch social transformation to humanize Western society and to provide an alternative to communism in the context of World War and the ensuing Cold War. In Weber's theoretical framework, a key factor in any transformative movement must be a highly motivated and committed constituency of lay people. While priests and bishops can make moral pronouncements and provide logistical support, it is only the lay people who can act as incarnational missionaries carrying the ethic of brotherly love into their respective spheres of work and life. According to Coleman, the task of developing a theology of culture leading to a concrete historical ideal ought to belong to lay people, rather than the clerical hierarchy. It is the laity that has the unique experience in the practical realities of marriage, family, neighborhood, secular work and politics. A compelling concrete historical ideal could only emerge out of real lived experience and lead to the appropriate Christian response. ${ }^{36}$

The role of student movements and Catholic Action suggests another historical tension which has existed between clergy and laity. Since the institutionalization of the Catholic Church as the organizational glue of the collapsing Roman Empire in the fifth and sixth centuries, the cleavage between the dominant role of the church clergy and the

\footnotetext{
${ }^{35}$ Souza, “JUC, Movimento Pedagógico,” 2, Bidegain Papers.

${ }^{36}$ Coleman, Strategic Theology, 39.
} 
subordinate role of the vast number of laity has been sharply defined. ${ }^{37}$ This distinction began to be challenged by the Protestant Reformation but was largely ignored by traditional Catholicism until the late nineteenth century.

With the development of Catholic Action, the popes and the church hierarchy began to work toward a more modern understanding of the important and participatory role of the Catholic layperson. Initially, the role of the layperson in Catholic Action was defined as "participation in the apostolate of the bishops." ${ }^{, 38}$ Lay activists were kept clearly subordinate to the clergy, especially in Italy where there was constant competitive pressure from fascism. In Spain, as well, the Catholic Church remained very conservative and authoritarian in the face of anticlerical persecution during the Spanish Republic and the Spanish Civil War. The Spanish and the Italian clergy were predominant among the foreign missionaries and regular clergy active in Cuba and thus exercised a correspondingly pervasive and conservative influence upon the Catholic Church in Cuba. ${ }^{39}$

Nouvelle Théologie

In France and Belgium, simultaneously with the development of the Jeunesse Chretiane Catholique and its brand of specialized Catholic Action, the aforementioned nouvelle théologie became an influential theological movement with Catholicism. Belgian and French theologians began to urge a reexamination of fourteenth and fifteenth

${ }^{37}$ Troeltsch, Social Teaching, 99.

${ }^{38}$ Misner, “Catholic Labor,” 18; Poggi, Catholic Action, 23.

${ }^{39}$ Yaremko, Missions in Cuba, 42; Yolanda Portuondo, Guillermo Sardiñas, Sacerdote Commandante - Testimonio (La Habana, Cuba: Editorial Cultura Popular, 1988), 51. 
century Catholic scholasticism by way of a return to the sources (ressourcement) including a critical reevaluation of St. Thomas himself and a more historicized study of the New Testament and the Patristic fathers. These Catholic scholars felt that Neoscholasticism created a "tightly fitting straightjacket" that was not open to reality and history. Neo-scholasticism had arisen partially in reaction to the "Modernist crisis" in France in the early twentieth century and gradually became exclusive and all-pervading in the Catholic Church. ${ }^{40}$

The Modernist position focused on introducing an historical perspective into theology (for example the historical-critical method or the study of the historical evolution of dogma). Both of these elements continued to be influential from around 1935 through Vatican II: "the Modernists set out to bring Catholic thought up to date, while the magisterium considered it its duty to condemn any mindset that posed a threat to the continued existence of the doctrine of the church. ${ }^{, 41}$ The new theologians of the period 1935-42 reacted against neo-scholasticism by insisting on a return to the historical Thomas, an emphasis that fitted well within the emerging historical interest in the middle ages.

Another theological development of nouvelle théologie encouraged increased emphasis on concrete, everyday life. This was often expressed by the use of the word "reality.” Christianity's `social action' became visible, as illustrated in Cardijn's Jeunesse Ouvriere Chretienne (JOC). ${ }^{42}$ Henri Godin, Y. Daniel and G. Guerin wrote a book called

\footnotetext{
${ }^{40}$ Jurgen Mettepenningen, Nouvelle Thologie - New Theology: Inheritor of Modernism, Precursor of Vatican II, Kindle Edition. (New York \& London: T. \& T. Clark International), 10, 11-12.

${ }^{41}$ Mettepenningen, Nouvelle Thologie, 21-22.

${ }^{42}$ Ibid., 28.
} 
France, pays du mission ${ }^{43}$ which was inspired by their daily contacts with the JOC. The JOC form of reflection and analysis based on the "see-judge-act" trilogy contributed significantly to the methodology of liberation theology's CEBS. ${ }^{44}$

Pope Pius XII acted against the nouvelle théologie in 1950 with the publication of Humani generis. This was Rome's last ditch defense of neo-scholasticism as a definitive theoretical framework for orthodox theology. Although Humani generis did not specifically mention the nouvelle théologie, it condemned thirteen new theological positions. The Pope attacked historicism as dangerous to the foundations of the universal truth of faith. $^{45}$

After 1942 through the eve of the Second Vatican Council, roughly paralleling the spread of specialized Catholic Action, the ideas emphasized in the nouvelle théologie became internationalized and traveled to other countries such as the Netherlands and the German-speaking world. The emphasis of the new theology also found its way to parts of Latin America especially through the Catholic students and university movement. In French Canada the student members of the JEC received and read copies of Mounier's Catholic philosophical journal Espirit. ${ }^{46}$ In Brazil, the university JUC's newsletters, pamphlets, and other publications contain frequent references to several of the representatives of nouvelle théologie as well as the concepts espoused by them such as "historical reali-

${ }^{43}$ Godin, H., Y. Daniel and G. Guerin, La France, pays de mission? (Paris: Cerf. French, 1943).

${ }^{44}$ Lakeland, Liberation of the Laity, 26.

${ }^{45}$ Mettepenningen, Nouvelle Thologie, 35.

${ }^{46}$ Gerard Pelletier, Years of Impatience: 1950-1960, Alan Brown (Toronto: Methuen, 1984), 102. 
ty" (la realidad), the need for an incarnational faith, and the need for the church to use modern social science tools to engage reality in new and innovative ways. ${ }^{47}$

Not all areas of the Catholic portion of western "Atlantic" civilization received the new theology enthusiastically. Italy and Spain, in particular, and other conservative Catholic nations such as Colombia and Cuba were cautious about welcoming the tenants of neouvelle théologie. Brazilian Catholicism was more accommodating to the new theology and specialized Catholic Action. Numerous Brazilian Dominicans were sent to Europe, to Belgium in particular, where they were exposed to new theological currents. ${ }^{48}$

The Second Vatican Council ultimately appropriated the central features of the nouvelle théologie. Many of the pioneers of the new theology, such as Henri de Lubac, Yves Congar and Hans Urs von Balthasar, played prominent roles in forming some of the great theological themes of Vatican II, as did future theologians of liberation such as Gustavo Gutierrez. ${ }^{49}$ The process of opening to the modern world undertaken by the Second Vatican Council was significantly influenced by nouvelle theologians who helped lead French Catholics out of a Neo-Scholastic and intellectual ghetto in the 1930s and 1940 s. $^{50}$

${ }^{47}$ Romeu Dale, “Uma Mistica Para a J.U.C,” unpublished essay (1959) 2, Bidegain Papers; Emanuel Mounier, "O Temporal Sacramento do Reino do Deus", JUC boletim nacional, No. 5/1959: 20, Bidegain Papers. Josaphat.

${ }^{48}$ Two of Brazilian Dominicans studied in Francophone Europe: Fr. Romeu Dale and Frei Carlos

${ }^{49}$ Mettepenningen, Nouvelle Thologie, 35-36.

${ }^{50}$ Michael Kelly, "Catholicism and the Left in Twentieth-Century France," Catholicism, Politics, and Society in Twentieth-Century France, Ed. Kay Chadwick (Liverpool, U.K.: Liverpool University Press, 2000) 159. 
As discussed at the beginning of this chapter, the active presence of a highly committed laity is an essential element in a transformative religious movement. The division between the clergy and the laity has presented a perennial problem for traditional Catholicism. Yves Congar (1904-1995) was the new theologian most interested in the problem of the division between the clergy and the laity. Congar lived through two World Wars and spent time as a prisoner of war during the second. In November 1925, he entered the Dominican order. He eventually encountered difficulties with the Vatican authorities over his support for the nouvelle théologie, as well as his openness towards ecumenism and history. ${ }^{51}$ His key work on the clergy-laity problems was published in 1953 as Jalons pour une théologie du laïcat (English title: "Lay People in the Church") and damaged his relationship with the magisterium. ${ }^{52}$ Congar's work attempted to create a bridge between the clergy and the laity and between the two widely separated spheres of theology and life. Congar insisted that the central reason behind the growth in secularization was the rupture between faith and life. ${ }^{53}$

Another nouvelle theologian to influence the development of the specialized Catholic Action was the Dominican Marcel Chenu (1895-1990). ${ }^{54}$ Chenu actively focused on the social life of the Church. His efforts to create an opening for the full integration of the laity included his participation in the young Christian workers movement

${ }^{51}$ Lakeland, Liberation of the Laity, 28.

${ }^{52}$ Yves Congar, Jalons Pour un Théologie Du Laicat, English: Lay People in the Church (Paris: Cerf, 1953).

\footnotetext{
${ }^{53}$ Mettepenningen, Nouvelle Thologie, 45.

${ }^{54}$ Ibid., 48.
} 
(JOC). Chenu introduced the vision of Joseph Cardijn to the Dominican authorities, who in turn offered the JOC their support. Chenu also encouraged the priesthood to open up to the reality of everyday life by promoting the worker-priests who took jobs as laborers and evangelized alongside their lay counterparts. Chenu wrote that the JOC has taken the lead in returning to the sources through its development of the See-Judge-Act method. ${ }^{55}$

The theologians who participated in the development of the new theology were forced to rethink theology in order to achieve their goal of reconnecting Catholic theology with modern realities. This required a departure from Neo-Scholasticism's reductionism of faith to abstract concepts. Despite the fact that the new theologians were obligated to start with Roman Neo-Scholasticism, they abandoned the scholastic 'system thinking' and pioneered a fresh theology focusing on "historical reality" using St. Thomas in his historical context of the thirteenth-century. This emphasis on historical reality included using empirical sources and scholarly criteria. The renewed connection between the Bible and theology was reaffirmed during Vatican II by the Council Fathers. These French Dominican and Jesuits theologians had a significant influence on Vatican II. They knew that if the church was to evangelize the French working class, it had to break out of its antimodernist, bourgeois and aristocratic mindset and reach out to a new audience with a fresh theology based on modern realities. ${ }^{56}$

Paul Lakeland observed that the layperson is the vanguard of the church's mission and has a paradoxical responsibility to humanize as well as to evangelize. In a pluralistic

\footnotetext{
${ }^{55}$ Mettepenningen, Nouvelle Thologie, 50-53.

${ }^{56}$ Lakeland, Liberation of the Laity, 24.
} 
world, an open and responsible dialogical relationship is necessary in order to offer transforming influence. The insertion into the secular world must open lay people to the demands of pluralism and to the elimination of structural oppressions ${ }^{57}$ Nevertheless, Lakeland concluded that the clergy, for all its good intentions, remained trapped in a clericalized view of the church. ${ }^{58}$

The Catholic university student movements successfully entered into the responsible "dialogial relationship" that Lakeland referred to, especially in Brazil. ${ }^{59}$ However, other than a few enlightened priests, most of church hierarchy became uncomfortable with the political radicalization of the student laity, eventually leading to the restructuring of the university movement in Brazil in 1966, just after the close of Vatican II and the decision of the JUC to disassociate from the church and the authority of the hierarchy. ${ }^{60}$

\section{Religion and Politics}

There has always been a right to left spectrum of political views within the Church. Since the French Revolution, the Church leadership has been primarily conservative, defending Catholic tradition and the power of the Papacy against the onslaught of revolutionary liberalism and anti-clericalism. Nevertheless, there were many of the lower priests in the early nineteenth century who represented liberal voices within the Church and advocated social and religious reform. As the battle between Enlightenment modernity and Catholic traditionalism intensified during the course of the nineteenth century, the

\footnotetext{
${ }^{57}$ Ibid., 100.

${ }^{58}$ Ibid., 108.

${ }^{59}$ Ibid., 100.
} 
Vatican hardened its conservative views under the banner of papal infallibility and issued the Syllabus of Errors in 1870 under Pope Pius IX. With Pope Leo X, the Vatican attempted to combat the "subjectivity" of Kantian philosophy by reaffirming scholastic Thomism as the required philosophical framework for Catholicism. ${ }^{61}$ Leo recognized the need for the Church to address the growing class conflict between capital and the labor movement in his encyclical Rerum Novarum which was titled "The Rights and Duties of Capital and Labor." (1891). ${ }^{62}$ Despite the Vatican's constant battle with the "error of modernism" in the early twentieth century, the social teaching represented in Leo's encyclical provided intellectual space for Catholic leaders who were concerned about social issues and the growing dechristianization of the working class. It was out of the fertile soil of Catholic social teaching that the early movements of Catholic Action sprang. ${ }^{63}$

The social classes and class tension that exist within industrial society also exist within the church, to the extent that the church is made up of people from every strata of society. Max Weber analyzed the political potential of religion in his Sociology of Religion. Weber was one of the first to point out that the social class divisions of society also exist within the Church. Whenever the members of the Church look to religion to legitimize their position in the social hierarchy, religio.n serves an inherently conservative social role, that of legitimization of the ruling order. Weber calls this a "religion of adapta-

${ }^{60}$ Beozzo, Cristãos, 50.

${ }^{61}$ Mettepenningen, Nouvelle Thologie, 19.

${ }^{62}$ Leo XIII, "On Capital and Labor," Rerum Novarum, Encyclical of Pope Leo XIII (Vatican Web site, May 15, 1891), Http://www.papalencyclicals.net/Leo13/113rerum.htm.

${ }^{63}$ Bidegain, Participación y Protagonismo, 28-31. 
tion to the world." ${ }^{64}$ However, when the poor and underclasses look to religion as a source of salvation, there is potential for religious faith to provide impetus for social activism, or even revolution. ${ }^{65}$

The hierarchy intended to use the youth sections of Catholic Action as missionary instruments of the church to project Catholic influence into secular venues and to recruit secular young people to Catholicism. ${ }^{66}$ However, as university students, trained by the See-Judge-Act method, began to evaluate their social milieus with scripture and with modern tools of social science, they became aware of the plight of the underclasses in their respective nations. Elite Brazilian and Cuban university students began to interact with Catholic working class youth. Thus, some Catholic university students began to shift their religious view from Weber's "religion of adaptation" to a religion of salvation and moved toward more progressive political views and affiliations. ${ }^{67}$ Eventually, the former Catholic student members of the JUC started Ação Popular, a radical Marxist political party. ${ }^{68}$

The Catholic students involved in the university movements in Brazil and Cuba is many cases underwent ideological transformations from conservative Catholic worldviews to progressive and even socialist political ideologies. ${ }^{69}$ This was a direct

\footnotetext{
${ }^{64}$ Max Weber, The Sociology of Religion (Boston: Beacon Press, 4th ed. 1991) 89, 97 and 107.

${ }^{65}$ Weber, Religion, 100, 106.

${ }^{66}$ Bidegain, "From Catholic Action to Liberation Theology," 5.

${ }^{67}$ Wanderly interview, September 27, 1988.

${ }^{68}$ Betto interview. July 8,1997. Nagamine $2^{\text {nd }}$ interview. November 3, 1988.

${ }^{69}$ Ibid.
} 
consequence of their involvement with radical non-Catholic students and of the application of critical thinking (in the form of See-Judge-Act method) to their country's social problems. ${ }^{70}$ It has been previously noted that the opening up of Catholic students to other ideological perspectives outside of the traditional Catholicism was encouraged by intellectual influences in the form of Franco-Belgian specialized Catholic Action and European nouvelle théologie to a greater extent in Brazil than in Cuba. In Cuba, as noted in chapter 4, the primary ideological influences in the church, apart from the progressive Franciscan journal La Quincena, was the anti-communist international organization Pax Romana, and of course the heavy predominance of Spanish clergy. ${ }^{71}$

The modern concept of ideology has been much debated and much studied. There is a vast literature on the history and varied meanings of the concept. ${ }^{72}$ Although there is not complete agreement as to the significance of the term, 'ideology,' there is a generally accepted consensus about some of the features common to ideologies. The concept of ‘ideology' can be seen to some extent in Francis Bacon's theory in Novum Organum of the "idola" which were preconceptions of error that served as obstacles in the path to true knowledge. The basic idea was that society and tradition may become sources of error. ${ }^{73}$

${ }^{70}$ Romeu Dale $2^{\text {nd }}$ interview, April 13, 1993.

${ }^{71}$ Portuondo, Sardiñas, 51.

72 John Gerring, “A Definitional Analysis,” Political Research Quarterly 50.4 (Dec 1997): 962.

${ }^{73}$ Karl Manheim, Ideology and Utopia: An Introduction to the Sociology of Knowledge, First published in German in 1929 as Ideologie und Utopie, translated by Louis Wirth and Edward Shils (New York \& London: A Harvest Book, 1985), 61-62. 
Napoleon used the word "ideologues" in a derisive sense of "doctrinaire" to designate those liberal philosophers who opposed his imperial ambitions. ${ }^{74}$

From Napoleon, it was only a short period before Karl Marx wrote his essay on The German Ideology (1845) in which morality, myth and religion are forms of ideology which serve a negative, mystifying function, as a tool of the dominant class to deceive the working class into a false consciousness regarding their subordinate status within society. In the Marxist sense, ideology is almost always pejorative-a tool of oppression. In classic Marxist theory ideology is a function of class position. ${ }^{75}$ In the late nineteenth century and the early twentieth century, a number of competing political ideologies arose during the period of rapid social change that accompanied the modernizing processes of industrialization and urbanization. ${ }^{76}$ Some authors have described these political ideologies as secular religions, with many of the same universalizing and totalizing features that characterize religious belief, such as obstinacy in the face of facts, counterarguments, and opposition. Ideology serves a social function similar to that of religion by providing to people symbolic systems of meaning. ${ }^{77}$

In the twentieth century, it became apparent that there were not only ideologies of the right, serving as tools for social control for ruling elites, but there were also

\footnotetext{
${ }^{74}$ Bernard Susser, Political Ideology in the Modern World (Boston \& London: Allyn, 1995) 17. Manheim, Ideology and Utopia: 72; Gerring, "Analysis": 963.

${ }^{75}$ David M. Minar, "Ideology and Political Behavior," Midwest Journal of Political Science 5.4 (Nov 1961): 325; Manheim, Ideology and Utopia, 73.

${ }^{76}$ Kenneth N. Walker, "A Comparison of University Reform Movements in Argentina and Colombia," Comparative Education Review 10, no. 2, Special Issue on Student Politics (June 1966): 260.
} 
ideologies of the left, seeking to overthrow the established order. The word, 'ideology,' gradually began to take on a broader definition as an integrated set of beliefs with economic and political implications, similar to terms like political culture, belief system, world-view, or the German Weltanschauung. ${ }^{78}$ Peter Berger, reflecting the emerging 'constructivist' theoretical framework, used the term plausibility structure. ${ }^{79}$

Nevertheless, ‘ideology’ often contains a more specifically political implication.

Karl Mannheim wrote his classic work, Ideology and Utopia, in 1929 just as ideological tensions were coming to a head in Europe. Mannheim moved away from the pejorative Marxist view of ideology as a tool of the dominant elite to a more universal view of ideology as "sociology of knowledge" or a "world-view" that everyone partakes in and that enables people to make cognitive sense of the world around them. In the Mannheimian sense, everyone has an ideology, just as every group, nation or society has ideologies. Mannheim also distinguished between ideology, which was held by the ruling class and was used to maintain social stability in the status quo, and 'utopia', which was a sort of ideology of the left, a belief system devoted to changing the status quo. Both utopia as well as ideology functioned in a similar manner of distorting reality in order to give a coherent and reassuring belief system for the respective groups, which nevertheless may create idola, or obstacles to true knowledge.$^{80}$ Mannheim also made a

${ }^{77}$ Gramsci, Prison Notebooks, 326, 328; John Gerring, “A Definitional Analysis,” Political Research Quarterly 50.4 (December 1997): 978.

${ }^{78}$ Manheim, Ideology and Utopia, 88; Minar, “Ideology,” 323.

${ }^{79}$ Peter L. Berger and Thomas Luckmann, The Social Construction of Reality: A Treatise in the Sociology of Knowledge (New York: Anchor Books, 1966), 154.

${ }^{80}$ Manheim, Ideology and Utopia, 40, 62. 
clear distinction between two conceptual categories of the significance of the term, 'ideology.' The first was what he called the 'particular' meaning, in the Marxist sense of the ideology of a ruling class designed to create a false consciousness in the subordinate classes. The second, was the total conception of ideology, which lies closer to the meaning of such words as world-view or belief system, and describe a mentality or way of thinking not necessarily designed for deception or for domination but simply socially constructed in order to help people make cultural sense out of reality. ${ }^{81}$

Political ideology can be defined as a set of ideas, beliefs, opinions, and values that (1) exhibit a recurring pattern and (2) are held by significant groups, (3) compete over providing and controlling plans for public policy, and (4) do so with the aim of justifying, contesting, or changing the social and political arrangements and processes of a political community. ${ }^{82} \mathrm{~A}$ common definition of religion is "symbolic systems of meaning. ${ }^{, 83}$ In an essay in the Journal of Religion, Tyler Roberts asserts that religions are "totalized systems of meaning." Roberts goes on to say that "Religion is an ideological metasystem that allows access to and is particularly effective at shoring up other ideological systems. ${ }^{, 84}$ In Roberts’ view, similar to Marx, religion often serves as a tool of false consciousness, impeding social revolution and under-girding false ideologies: "refusing to recognize that they are products of human construction, religions close

${ }^{81}$ Ibid., 56-57.

${ }^{82}$ Michael Freeden, Ideology, A Very Short Introduction (Oxford: Oxford UP, 2003), 32.

${ }^{83}$ Clifford Geertz, The Interpretation of Cultures (Princeton, NJ: Basic, 1973), 89-90.

${ }^{84}$ Tyler Roberts, "Rhetorics of Ideology and Criticism in the Study of Religion," The Journal of Religion 85.3 (July 2005): 372. 
themselves off from critical revolutionary questioning; it is this closure that makes it possible for religions to protect and stabilize ideological systems." ${ }^{, 85}$

Through mystification, religions may function ideologically to reproduce specific social values as if they were universal. There is a clear difference between theoretical discourse and ideological discourse: theoretical discourse concedes its historical and social particularity and fallibility. On the other hand, ideological discourse obscures the historical and social process by which human beings, in both religious and non-religious ways, construct normative visions of reality. ${ }^{86}$ Many in the ruling elites use religion as a support of their own political beliefs and to impose political order. ${ }^{87}$ Roberts describes ideology as an idealism that masks the true conditions of human life. ${ }^{88}$

Ideology is a particular type of cultural belief system, focused specifically on the political aspect of society. Ideology is held by people within a culture and is distinct from the culture only in that it specifically addresses the political sphere. In this sense, ideology bears striking resemblance to "religion" or "common-sense" - as aspects of the construction of meaning within the cultural system. Geertz believed that ideologies were more likely to arise during times of cultural crisis. When the traditional patterns of meaning (in the political field) are inadequate for providing an interpretive framework for making sense of the world, ideologies are a cultural response. According to Williams,

\footnotetext{
${ }^{85}$ Ibid.

${ }^{86}$ Ibid., 376.

${ }^{87}$ Freeden, Ideology, 88.

${ }^{88}$ Roberts, "Rhetorics of Ideology." 370.
} 
ideologies emerge as comprehensive systems of meaning at times when current cultural systems seem unable to handle social change. ${ }^{89}$

Ideology is a set of symbolic objects. In the same way that a human group cannot be without culture, people cannot act politically without an ideology. In one sense any set of political attitudes, beliefs, or values, could be designated as part of an ideology. Religion can also serve as an ideology. Social movements often use religious or moral arguments to press their claims for political action. In a variety of combinations of religion, race, and gender, political challengers may use the cultural power of religious symbols to force their issues onto the public agenda. ${ }^{90}$

Ideology also contains a reactive element which develops it's self-identity in opposition to an oppressive 'other'. In Cuba, Catholic students initially defined their ideology in a critical stance against the corruption and brutality of the Batista regime. Hundreds of Catholic students joined the student Directorio Revolucionario (revolutionary directory) or the 26 of July movement. La Quincena magazine served as a voice for the progressive wing of the Catholic Church calling for a return to honest elections and agrarian reform. The Catholic social teaching of Leo XXIII and Pius XI served as a foundation for a Catholic communitarian ideal. ${ }^{91}$ Once the United States began attempting to undermine the Cuban revolution and Castro began to move toward a strategic alliance with the Soviet Union, the perceived enemy changed. The repressive

\footnotetext{
${ }^{89}$ Williams, "Religion: Culture or Ideology?" 370.

${ }^{90}$ Ibid., 375.
} 
'other' was no longer Batista's regime but now was Castro and the revolutionary regime. Some students and priests continued to support the revolution, however most began to shift to the anti-communist right in opposition. In Brazil, Catholic students moved toward the political left in conscious opposition to entrenched political elites and business interests. For a time, the Catholic student movement maintained influence with the populist administration of João Goulart. However, a right-wing military coup in April 1964 began to take repressive measures against the student movements and eventually against the church itself. It is no surprise that the Brazilian Catholic students accelerated in their left-ward radicalization in opposition to the threat of military reprisal and torture. $^{92}$

How can religious ideology be distinguished from religious faith? Ideology contains certainties; faith contains mysteries. Ideology promotes militancy; faith promotes humility. Ideology must be implemented with energetic human force; faith rests in the providence of God. Ideology produces antagonism between opposing parties; faith produces love for one's enemy that bridges opposition.

The Second Vatican Council, initiated by Pope John XXIII and lasting from 1962 to 1965 , unleashed another revolution of a different kind in the 1960s, alongside the $\mathrm{Cu}$ ban Revolution (1959) and the so-called conservative Brazilian 'revolution' (1964). ${ }^{93}$

${ }^{91}$ The "Social Teaching" of the church usually refers to Leo XIII's Rerum Novarum (1891) and Pius XI's Quadragesimo Anno (Latin for "In the 40th Year") in which the Pope's recognized the legitimate rights of the working class and the poor.

${ }^{92}$ Wanderly interview, September 27, 1988; Betto interview, July 81997 ; Nagamine $2^{\text {nd }}$ interview, November 3, 1988.

${ }^{93}$ The Brazilian military leaders who carried out the coup d'estat of April 1964, referred to their action euphemistically as a "revolution." 
Catholic sociologist Andrew Greely described the significant changes in Catholicism as a revolution which resulted in fundamental changes in attitudes and practices of the faithful Catholic laity. ${ }^{94}$ The bishops who participated in the Council were in full agreement with John XXIII that reform was necessary (while the Vatican curia disagreed). Nevertheless, they badly underestimated how destabilizing the effects of attempted reform would be on the structures of the church. ${ }^{95}$

Vatican II was an attempt at reform. The crucial issue in the attempted reform was the Church's right to make moral "rules" and require the obedience of the laity to these rules. All reforms usually require someone to yield power, and, in the case of the Church, the Vatican curia and higher bishops stood to lose power. According to Greeley, once reforms were attempted, a type of revolutionary sentiment spread within Catholicism resulting in a chaos that alarmed many Church leaders. By the mid-1970s, the right of the Church to legislate obedience to moral rules of sexual behavior had been challenged. The student unrest that erupted in much of Western civilization in the late 1960s also alarmed the bishops. They quickly clamped down on the reform movement as they had earlier shut down the Catholic Action student movements. ${ }^{96}$

Brazil and Cuba

In this dissertation, Catholic Action university movements in Brazil and Cuba have been examined and compared. A comparative study of Brazil and Cuba offers fertile

\footnotetext{
${ }^{94}$ Greeley, Catholic Revolution, 12.

${ }^{95}$ Ibid., 15.
} 
ground for scholarly inquiry because of their rich similarities: the historical influence of Iberian Catholicism, colonialism, the long enduring institutions of slavery, the existence of extreme poverty and pressing social crises in the 1950s. Nearly as interesting are their contrasts: Spanish versus Portuguese Catholicism, island versus sub-continent, and most importantly for our purposes, general Catholic Action versus specialized Catholic Action.

Both Cuba and Brazil experienced lively Catholic Action movements beginning in the 1930s and accelerating in growth and social influence in the postwar 1950s. Both Catholic student movements were patronized and promoted by their respective clerical hierarchies. Both student movements were composed of highly committed youth and lay people -- often called "militants" - attempting to infuse Catholic social values (the ethic of brotherly love) into their respective secular arenas, particularly at the university level. Both Catholic Action student movements pursued the vision of a concrete historical ideal in the form of a more just and communitarian society based on Catholic concepts of brotherly love and social justice. Both student movements were active in a time of excessive social upheaval in their respective countries, culminating in one case in a social revolution, and in the other, a conservative military coup that turned into a repressive, 24year military dictatorship. In both student movements there was a great deal of youthful idealism and there were casualties and martyrs on the behalf of their desired ideal of an ethic of brotherly love. ${ }^{97}$

${ }^{96}$ Greeley, Catholic Revolution: 13-15. Greely cites the London Tablet as describing the reaction of the curia as having "aborted the reform."

${ }^{97}$ As previously mentioned, Weber developed the idea of acosmic love, or the religious ethic of brotherly love. Jacques Maritain developed the concept of the 'concrete historical ideal' as an alternative to unattainable utopia. 
In the middle of the twentieth century, Brazil and Cuba passed through similar periods of development. Despite the vast differences in size, language, and geography both Brazil and Cuba had been slave societies until late in the nineteenth century and both countries shared a colonial Catholic heritage. With the arrival of modernity in the twentieth century, as elsewhere in Latin America, both countries experienced a rapidly expanding need for an educated work force and professional training which translated into a growing student population. ${ }^{98}$

The Catholic Church in both countries was institutionally weak in the nineteenth and early twentieth century, although the Brazilian church had experienced a period of revival of influence described as "neo-Christendom" during the Vargas regime in the 1930s under the strong leadership of Archbishop Sebastião Leme da Silveira Cintra. ${ }^{99}$ After the First World War, the Catholic episcopal hierarchies in both countries followed the lead of the Catholic Church in Europe in placing greater emphasis on the recruitment, training and mobilization of youth as part of a strategy of "rechristianization" of their respective societies. The effort was channeled primarily through general Catholic Action, following the lead of the Italian model of lay activism. In Cuba, a French priest, Hermano Victorino established the Cuban Catholic Youth movement in 1927. In Brazil, under

\footnotetext{
${ }^{98}$ Brazilian Ministry of Education and Culture as cited in Souza: $A J U C, 75$.

${ }^{99}$ Dom Sebastião Leme da Silveira Cintra (1882-1942) was successively Archbishop of Olina, Recife and Rio de Janeiro and was named a Cardinal in 1930 a few months before he played a key role in resolving the Brazilian Revolution of 1930 by persuading the President, Washington Luis to resign. His role opening the way for the administration of Gétulio Vargas made him influential with the Brazilian government and allowed the Church to regain some of its lost prestige: Skidmore, Politics in Brazil 1930-
} 1964, 10. 
Archishop Sebastião Leme in the 1930s, the Brazilian Catholic Youth was established as one of the four branches (Ramas in Spanish) of general Catholic Action.

Catholic organizations focusing on university youth soon followed. In Cuba, the ACU (Agrupación Católica Universitaria) was founded by the Jesuits in the 1930s and largely operated under the umbrella of general Catholic Action as an affiliated organization. The JUC, representing the Franco-Belgian specialized Catholic Action, began in Cuba after World War II, but only in a restricted fashion. In Brazil, the JUC was formed in the 1930s as a lay-led organization within Catholic Action and largely influenced by Dominican priests. Several of the key clerical leaders of the Brazilian JUC were themselves trained within the ranks of the university movement during the interwar period; among them Fr. Romeu Dale and Dom Cândido Padim, both of whom had a significant formative role in the postwar development of Catholic student movements in Brazil. ${ }^{100}$

After the Second World War, the demand for higher education grew rapidly, and along with it, the numbers of university students. From 1950 to 1970, the numbers of university students enrolled in Brazilian universities grew an average of eleven percent per year, beginning in 1950 with a total of slightly more than 52,000 college students and expanding to just under half a million students by $1970 .{ }^{101}$ Along with the growth in sheer numbers of university students, the political influence of university students also increased at the national level. ${ }^{102}$ In Cuba, there was a tradition of university political ac-

\footnotetext{
${ }^{100}$ Dale interview April, 13, 1993; Padim interview, May 28, 1990;

${ }^{101}$ See Appendix for a graphic representation. Brazilian Ministry of Education and Culture cited in Souza, 1984:7.

102 Therry, “Dominant Power Components," 29.
} 
tivism dating back to the student revolution of $1933 .{ }^{103}$ University students in Latin America were normally children of the ruling elites, and as such exercised a social influence beyond their demographic or professional status. ${ }^{104}$

As mentioned previously, the ideas and methods of specialized Catholic Action began to arrive in Cuba in the postwar period, through the JOC, or Young Christian Workers. However, Hermano Victorino, the founder of the JCC, or the Young Cuban Catholics movement, expressed caution about utilizing the tools of specialized Catholic Action. He was concerned about a rupture between the Catholic lay students and the church hierarchy and urged that the SCA be modified and adopted piecemeal into the Cuban Catholic youth movement. Chapters of the JUC (university) and the JEC (high school) were begun in Cuba in the postwar period and existed alongside of the older and more traditional ACU, but were not allowed the same degree of autonomy or influence as the Brazilian JUC. As has been previously discussed, the Catholic university and student movements were heavily involved in the insurrection against Batista, but began to be alienated from the Cuban Revolution as Castro began to realign himself with the Soviet Union.

In Brazil, the Catholic University student movement was central to the social ferment of the early 1960s. Of course, there was a wide diversity of views among the bishops. The statements of the bishops were likely influenced by the overall atmosphere of radicalization. Some of the bishops vacillating between opposing views and were

\footnotetext{
${ }^{103}$ Suchlicki, University Students, 12.

${ }^{104}$ Altbach, "Student Politics," 638.
} 
reluctant to express more conservative views. After the military coup in April 1964, the bishops became more cautious. Dom Helder Câmara was removed as secretary of the Bishops Conference as an attempt to moderate the church's position. The climate of openness to change from the Vatican Council may have strengthened the progressives temporarily. However, probably only 10-20 percent of Brazil's bishops were outspoken progressives. $^{105}$

The coup d'etat of April 1964 greatly restricted the radical Catholic students' options for activism. Many radical Catholic university students, such as Frei Betto, suffered torture and imprisonment under the repressive military regime. ${ }^{106}$ They were forced by the coup to re-examine the connection between political ideologies and their Catholic faith. Some observers believed that there had been too much naïve idealism prevalent in the student movement. ${ }^{107}$ The students eventually realized their need to strengthen the spiritual side of their social consciousness and to exercise more caution in the political sphere. Nevetheless, Catholic university students who had been trained with the See-Judge-Act method of specialized Catholic Action played a key role as critics of the military repression and advocated a return to democracy in Brazil. Some church leaders attempted to warn the students of the danger of naïve political engagement, but offered few pragmatic suggestions. The bishops expounded on the social teaching of the church, but often in an abstract and theoretical way that was not connected to reality. ${ }^{108}$

\footnotetext{
${ }^{105}$ De Kadt, "Religion": 208.

${ }^{106}$ Betto interview, July 8, 1997.

${ }^{107}$ Borelli interview, January 26, 1990; Alves, Grain of Mustard Seed: 125.
} 


\section{CONCLUSION}

How does one evaluate the effort of two generations of Catholic students to engage the problems of their societies on the basis of their faith and their Catholic values? The students examined in this dissertation were active during the Great Depression, World War II, the Cold War and finally the turbulent years of the Cuban Revolution and the suspension of democracy in Brazil. The forty-year period of work of Catholic Action among university students culminated with major global events such as the Cuban Missile Crisis and the convening of the Second Vatican Council. By the 1970s, most of the specialized Catholic Action university movements had been closed down in their respective countries, or folded into Pax Romana's more conservative student ministry. $^{109}$

As pointed out earlier, John A. Coleman used Weberian theory to suggest three requirements for the church to undertake an effective transformative societal mission. The first condition is sustained and irresolvable tension between a vision for an ideal social order based on mutuality, community and justice, and the need to accommodate such a vision to the practical demands of the real world. Coleman observed that Christianity is unique among world religions precisely because the paradoxical doctrine of the incarnation in which Christ is viewed as fully divine and at the same time fully human. ${ }^{110}$ Two dominant tendencies of most religions are to accommodate to the structures of society (for example in this study, social hierarchy) or to flee engagement

\footnotetext{
${ }^{108}$ De Kadt, "Religion,” 212.

${ }^{109}$ Bidegain, "From Catholic Action to Liberation Theology," 5.
} 
with current society in rejection of the world. According to Coleman, the belief in the paradoxical mystery of the incarnation is the "radical source of the Christian refusal" to retreat into a religious ghetto on the one hand, or on the other, to follow a path of worldly accommodation to such degree that it loses its prophetic-critical edge and activist ethods. $^{111}$

Students who were members of the Catholic university movements walked the keen edge of the incarnational paradox. During the period of "closed Catholicism" the church attempted to isolate itself from dangers and ills of secular society. ${ }^{112}$ At the same time, however, the church called upon its lay people, particularly the youth, to participate in the 'apostolate' of the hierarchy. In Catholic terminology, the apostolate is the outward, missionizing thrust of the church toward world transformation and redemption. According to Dom Cândido Padim, national advisor to the Brazilian university movement from 1961 to 1965 , the church hierarchy put the students in an impossible situation. ${ }^{113}$ On the one hand, the bishops had demanded of the students that they attempt to sacralize secular society. On the other hand, they restricted the same students and lay workers from effectively realizing their goals as lay people. ${ }^{114}$

${ }^{110}$ The Council of Chalcedon, $451 \mathrm{CE}$, http://www.dailycatholic.org/history/4ecumen2.htm

${ }^{111}$ Coleman, Strategic Theology, 40.

112 John Henry Whyte, Catholics in Western Democracie: A Study in Political Behaviour (Dublin: Gill and Macmillan, 1981), 75.

${ }^{113}$ Padim interview, May 28, 1990.

${ }^{114}$ Beozzo, Cristãos: 50. 
The second element that Coleman puts forth as a condition for a church movement to have a transforming social influence is a "consistent pastoral strategy aimed at eliciting solid motivational commitments among the laity such that they see the world and their life of work as an arena of meaningful religious action." This study has outlined the pastoral strategy of encouraging and mobilizing the Catholic laity, in particular the youth, through Catholic Action beginning in the early twenties with Pius XI in Italy and Joseph Cardijn in Belgium. By-and-large, church officials continued a consistent pastoral strategy to encourage the laity to be involved in the apostolate of the hierarchy through outreach into their respective social milieu; although, as presented above, there were significant differences between the Roman-style general Catholic Action and Franco-Belgian specialized Catholic Action. With some variations from country to country, this pastoral strategy continued for forty years until the close of the Second Vatican Council.

Coleman's third condition moves beyond the pastoral strategy to the actual energetic lay commitment to concrete action in order to infuse religious values into the secular realm. ${ }^{115}$ In this area, the work of specialized Catholic Action in French Catholic countries and Brazil is notable. In areas where the Franco-Belgian specialized Catholic Action model predominated among university students, tremendous lay energies were released in recruitment, training and the growth of the student movements. In Brazil, the JUC became an influential voice within the overall secular university student union (UNE), and after 1961, the elected national presidents of the UNE were Catholic student

${ }^{115}$ Coleman, Strategic Theology, 39. 
leaders from the JUC and had a national voice with the Presidential administration of Goulart. ${ }^{116}$ The JUC was also involved in advocating social reform and was active in the literacy campaign. After 1964, Catholic students were actively involved in the resistance to the military dictatorship and many were imprisoned and tortured for their convictions. Many Non-Catholic leftists such as Marcio Alves were deeply impressed with the Catholic students and their commitment to social justice and subsequently embraced the Catholic faith. Many of the principles of social justice that were later to be articulated by theologians of liberation were first worked out in practice by the young Catholic jucistas.

As discussed previously, generalized Catholic Action was forced to become largely apolitical in Fascist Italy in the late 1920s and early 30s in order to survive under Mussolini. Also, the twin effects of Pius XI's authoritarianism and the need to keep a tight rein on Catholic Action in Italy in order to accommodate Fascism caused general Catholic Action to lose a significant amount of lay autonomy as overall control was squarely in the hands of the bishops. The upshot of these factors was that general Catholic Action youth movements were often largely oriented around the diocese and focused primarily on the internal life of the church in areas of piety, doctrine and liturgy. In Cuba, the dominant form of Catholic Action was the Italian-style general Catholic Action. The Catholic Church in Cuba was dominated by foreign priests, especially from Spain and Italy. The Catholic Action youth movement begun in the 1930s was led by a conservative French priest who endeavored to maintain a clear focus on personal morality and spiritual devotion among the youth. The original Catholic

${ }^{116}$ União Nacional de Estudantes (Brazilian National Student Union). 
university movement in Cuba, the ACU, was Jesuit-led and was not influenced by specialized Catholic Action until after World War II and then in only a cursory fashion. When the Franco-Belgian form of specialized Catholic Action did arrive in Cuba in 1947, Hermano Victorino advised the church hierarchy to avoid the full implementation of the specialized method in order to avoid fragmentation and disunity. A new university student organization called the JUC was begun under the oversight of the Franciscan order cautiously incorporating some aspects of the specialized method. ${ }^{117}$

In Cuba, the Franciscans represented a progressive wing of Cuban Catholicism. Father Inacio Baian was a Basque Franciscan and editor of the Catholic journal, $\mathrm{La}$ Quincena which supported the Cuban Revolution (although not Soviet Marxism) until its closure in 1961. Although the general Catholic Action youth movement under Hermano Victorino had grown rapidly during the Second World War, the specialized university movement, the JUC, was still rather small by the time of the first stirrings of the Cuban civil war in 1955. According to the records of the Diocesan Assembly, from 1955 to 1957 there were only six university groups in Havana representing the JUC, and of the High School JEC, there were only 16 in Havana. ${ }^{118}$ These were turbulent years for Cuba. The University of Havana was closed due to student unrest almost as much as it was open. The Cuban Revolution was already beginning and Batista's regime was suppressing any signs of resistance. There was no time for students to mount peaceful advocacy for social reforms in Cuba. The only viable option for idealistic students to attempt to initiate change in Cuba was to become involved in the efforts to remove

${ }^{117}$ Hermano Victorino to Cardinal Arteaga, October 1950. 
Batista or to become apolitical. Many Catholic students as well as priests decided to join the Cuban Revolution in the hopes that by removing Batista from power, social reforms might be possible under a new administration.

Returning to Coleman's second point, the national clergy overseeing Catholic Action in Cuba adopted a pastoral strategy designed to limit lay autonomy and to guard against any dangers of sectarianism. Between late arrival of specialized Catholic Action in Cuba, the cautious attitude of the church authorities and the rapid dissolution of political and social institutions during the Cuban Revolution, the Catholic university students never really had a chance to try to put the methods of specialized Catholic Action to work. By the time they gained organizational momentum, their only realistic options were to join the insurrection or withdraw into apolitical passivity. After Castro realigned the Revolution with the Soviet Union in the Cold War in 1961, only a very few former students and priests continued to support the Revolution. Most went to exile in Miami and began to work for a counter-revolution.

The highly energized lay efforts of the students in Brazil were infused into Brazilian society during the turbulent period of the 1960s. Despite the growing national influence of the Catholic student movement, their efforts for peaceful social reform came to a halt in 1964 with the assumption of power by the military. In 1965, the Brazilian bishops, gathered in Rome at the Second Vatican Council, crafted a plan to organizationally restructure the JUC and imposed their plan without consultation with the student leaders of the JUC. As a consequence, the JUC decided to separate themselves from the Catholic hierarchy. The "sustained pastoral strategy" for the mobilization of lay

118 “Memoria,” 1955-1957, FJFACC. Diocesan Assembly VIII. Archbishop's Archives. 
energies came to an end in Brazil in 1966. Although the JUC attempted to continue to function as a political movement, they had lost the fine balance of the incarnational paradox. They were were now a fully politicized secular entity and had lost the spiritual balance that, according to Coleman, was needed to become a transformative movement.

Chapter one of this dissertation presented Antonio Gramsci's theoretical analysis of the so-called "war of position" in his attempt to draw lessons from Italian Catholicism, particularly Italian Catholic Action. As stated earlier, Gramsci was pessimistic about the prospects for a violent overthrow of the ruling order. In his day, Soviet-style MarxistLeninism believed that a vanguard party must seize the monopoly of force of the state in order to impose new economic structures upon society. Gramsci did not believe that this "war of maneuver" had a high chance for success in the context of Italian fascism. He proposed an alternative, which he described as a "war of position;" a gradual process of education of the popular masses in order to inculcate a social consciousness into them; thus building up popular support at the grass roots level for social change. ${ }^{119}$ Gramsci believed that the ideological 'war of position,' or that is, a gradual process of consciousness raising must first take place in the minds of the people before a more literal 'war of maneuver' could lead to an abrupt and radical change in economic and social structures could take place. ${ }^{120}$

Beginning in Belgium with young workers in the mid-1920s, specialized Catholic Action actually did carry out a spiritual 'war of position' with a sustained pastoral

\footnotetext{
${ }^{119}$ Gramsci, Prison Notebooks, 12-13, 182.

${ }^{120}$ Gramsci, Prison Notebooks, 88, 120, 229. 366-7.
} 
strategy and the mobilization of tens of thousands of young workers and students, from Belgium to France to Quebec and to Brazil among other nations of Latin America. The social consciousness of multitudes of young people were raised through the See-JudgeAct method of critical awareness. Even after their involvement with the church and the university movements ended, many of these young people went on to become national leaders in their respective countries such as former Canadian premier Pierre Elliott Trudeau (1919-2000) and former journalist and Ambassador Gerard Pelletier (19191997). In Italy, former Catholic student members of the FUCI came to power through the Christian Democrats such as Aldo Moro (1916-1978) and Giulio Andreotti (1919-2013) who both at one time or another became Premier of Italy. A number of Catholic student leaders in Brazil and Cuba rose to prominent international positions of leadership within their respective organizations such as Souza (JECI) of Brazil and Raul Gonzalez Simon (Pax Romana) of Cuba. ${ }^{121}$

What were some of the factors that kept Catholic Action from having a greater impact in social transformation? First, there was too much clerical control and not enough empowerment for the laity. This was particularly true in Italy and later in Cuba. Pius XI commissioned the Catholic Action laity to "participate in the apostolate of the bishops" in 1922, but effectively shackled the lay leaders to diocesan and clerical control in order to avoid disturbing the uneasy truce that existed between the fascists and the church. There was a sustained pastoral strategy to recruit the laity, and there was a commitment on the

${ }^{121}$ Roger Pochon and Ramon Sugranyes de Franch, "Pax Romana, 1921-1961: Pax Romana Down the Years," unpublished manuscript (Friburg, Switzerland, 1961) 14, http://www.icmicamiic.org/en/. 
part of the laity to carry out the apostolate in practical ways. However, they were largely reined in by the hierarchy in the attempt to prevent them from becoming too political. Something similar happened to Catholic Action in Spain leading to its demise in 1966 and the disillusionment of many former members of Spanish Catholic Action. ${ }^{122}$ In Cuba, the church authorities failed to offer resistance or criticism of the corruption of the Batista regime and hesitated to take a clear stand on social and political issues confronting the nation. Catholic students were left to make their own choices from a number of possible options regarding the Cuban Revolution. ${ }^{123}$

Second, in those areas where the laity and the students were given ample autonomy, the university movement grew rapidly, were energetically involved in the life of the nation, but eventually became highly politicized and lost their spiritual balance. The prime example of this is found in Brazil. The student movements eventually became virtually the same as secular political movements and lost their sacred component. Eventually, the Brazilian bishops, under the pressure of the military dictatorship felt it necessary to bring to an end the mandate of the JUC. A similar process occurred in numerous nations of Latin America and Europe. In country after country, Catholic Action university student movements were closed down by their respective bishops during or by the end of the Second Vatican Council.

Did Catholic Action play a part in the Second Vatican Council and the subsequent Catholic Revolution? Many of the themes that were dear to the leaders of specialized

${ }^{122}$ Monteiro Garcia, La Acción Católica y el Franquismo, 55.

${ }^{123}$ John M. Kirk, Between God and the Party: Religion and Politics in Revolutionary Cuba (Tampa: University of South Florida Press, 1989), 44-46. 
Catholic Action were woven into the deliberation at the Second Vatican Council. In an interview Dom Cândido Padim discussed the directives of Vatican II and offered the opinion that "all of the tendencies of Catholic Action were confirmed and recognized by Vatican II." $" 124$

This dissertation does not have enough evidence to posit a solid causal link between the political liberalization of specialized Catholic Action and the progressive initiatives of the bishops of the Council, but it seems reasonable to assume that the progressive theological and ideological developments in Catholic Action, especially with the university students, corresponded and possibly contributed in some measure to an overall progressive trend among many of the Council bishops ultimately leading to the opening to modernity. It also seems likely that as the bishops sensed the "revolutionary effervesces" within Global Catholicism spinning out of control after the close of the Council, that they may have begun closing down the specialized Catholic Action youth movements in country after country out of fear of losing control of the church, particularly the laity.

What would have happened if the bishops had continued to give their unconditional support to the multitude of Catholic lay people who were actively committed to redemptive engagement in their respective societies? How might things have turned out differently if the bishops had trusted the Catholic laity with their full support for acting in the world to bring about Maritain's concrete historical ideal, founded on the "ethic of

\footnotetext{
${ }^{124}$ Padim interview, May 28, 1990; Bidegain, "Catholic Action to Liberation Theology," 17.
} 
brotherly love?" ${ }^{\prime 25}$ Could the young people of Catholic Action have iniated a new Christian social order infused with values of justice, pluralism, equality and commitment to the common good? Was there the potential for a world transformative socio-religious movement such as is delineated in Troeltsch's study of Catholicis in the Middle Ages and the Ascetic Protestantism of the early modern period? ${ }^{126}$ One cannot safely generalize from the available data or speculate on what 'might have been.' One can only conclude that two generations of Catholic youth heroically committed their energies to resolving the tensions between western capitalism and eastern Marxism and between secular modernity and sacred tradition.

${ }^{125}$ Coleman, Strategic Theology, 39; Bellah, 278; H.H. Gerth and C Wright Mills, 329; Troeltsch, Social Teaching, vol. 1, 288, 301.

126 Troeltsch, Social Teaching, vol. 1, 306-7; vol. 2, 815-20; 
APPENDICES 


\section{APPENDIX 1}

\section{LIST OF ABREVIATIONS AND ACRONYMS}

\begin{tabular}{|c|c|}
\hline B. & zilian Catholic Action \\
\hline ACI.. & Italian Catholic Action \\
\hline ACE. & .Spanish Catholic Action \\
\hline AIB. & Ação Integralista Brasileira (Brazilian Integral Action) \\
\hline ANEC. & Asociación nacional de Empleados Católicos \\
\hline AP. & Ação Popular (Popular Action) \\
\hline CR. & Catholic Charistmatic Renewal \\
\hline EBs... & Comunidades eclesiais de base (Eclesial Base Communities) \\
\hline CEDECOL. & Evangelical Council of Colombia \\
\hline CELAM...................... & Latin American Bishops Conference \\
\hline IDI... & International Center for Information and Documentation (Paris) \\
\hline NBB... & National Brazilian Bishops Council \\
\hline ECCLA. & Catholic Charismatic Encounters Latin America (Bogotá) \\
\hline ELN.. & National Army of Liberation \\
\hline FUCI.. & Federation of Italian Catholic University students \\
\hline SC. & International Student Conference \\
\hline JS.. & International Union of Students \\
\hline EC. & Juventude Estudiantil Catolica (Young Catholic Students) \\
\hline ECF.. & Young Catholic Student Women \\
\hline CI.. & Jeunesse Étudiant Catholique Internationale \\
\hline UC.. & Juventude Universitaria Catolica (Catholic Unive \\
\hline JOC. & Young Catholic Workers \\
\hline MIIC. & $\begin{array}{l}\text { International Catholic Movement for Intellectual and Cultural Af- } \\
\text { fairs, the intellectual branch of Pax Romana }\end{array}$ \\
\hline MIEC. & $\begin{array}{l}\text { International Catholic Movement for Intellectual and Student Af- } \\
\text { fairs, the student branch of Pax Romana. }\end{array}$ \\
\hline MEB.. & The base education movement in Brazil. \\
\hline PCB... & Partido Comunista Brasileira (Brazilian Communist Party). \\
\hline $70 \mathrm{P}$ & Partido Comunista do Brazil (Maoist Comunist Party of Brazil). \\
\hline .......... & Partido Liberal (Liberal Party). \\
\hline & Partido Trabalhador (Workers Party). \\
\hline PUC. & Pontificia Universidade Católico (Pontifical Catholic University). \\
\hline CA. & Specialized Catholic Action. \\
\hline NE. & União Nacional de Estudantes $(\mathrm{Na}$ \\
\hline & United Nations Educational, Scientific and $\mathrm{Cl}$ \\
\hline
\end{tabular}




\section{APPENDIX 2}

\section{GLOSSARY}

Ação Popular.................... A political offshoot of Catholic Action

Acción Católica......................Spanish-Catholic Action

Aggiornimento.................... Vatican II was characterized as an "opening"

(Italian - aggiornimento) to modernity."

Banca evangélica...................Portuguese-Evangelical caucus.

Christendom......................A Christian theocracy, a government devoted to the enforcement of Christian values.

Circoli Universitari Cattolici.......... Catholic university circles. Precursor (1874) to the Italian Catholic university movement.

Continuismo........................(Continuance) The tendency of authoritarian political leaders to want to remain in power.

De Rerum Novarum................. (Of New Things) Leo XIII's encyclical of 1891 dealing with the conditions of the working classes.

El Yocismo....................... The Catholic Youth Workers (JOC) movement

Evangélico........................ The generic term used in Latin America and Brazil for non-Catholic Protestant Christians.

Federazione Universitaria Cattolica Italiana: The Federation of Italian Catholic University students founded in 1896.

Federación Estudiantil Universitaria The Cuban Federation of University Students.

Gioventù Cattolica.................."CatholicYouth," the general Catholic Youth branch of Italian Catholic Action.

Gioventù Universitaria Fascista..... The Fascist University Youth

Jeunesse Etudiant Catholique.......... Young Catholic Students.

Jeunesse Universitaire Catholique.... Catholic University Youth.

Juventud Católica Cubana (JCC)... Cuban Catholic Youth (1928)

Movimento da Educação de Base...... The base education movement started in Brazil (1961) based on the pedagogy of Paulo Freire.

Movimiento de Liberación Radical....Founded by members of the JAC (1953) with the intent of opposing Batista.

Neo-Christendom................... An ideology of Catholic religious monopoly. Neo-Christendom flourished in Brazil (1930s).

Opera dei Congressi...................."work of the Congress" (see footnote \#24), a term used to describe the various Catholic lay organizations in the late nineteenth century before they were called "Catholic Action."

Padres Operários.................. Working priests

Pax Romana.................... An international organization of Catholic intellectu-als promoting peace, located in Swizterland.

Ultramontane (Beyond the mountains) A doctrine supporting Papal supremacy over diocesan authority. 


\section{APENDIX 3}

UNIVERSITY ATTENDANCE IN BRAZIL (1950-70)

\begin{tabular}{|r|r|r|}
\hline Years & Total Students & \multicolumn{2}{l|}{$\begin{array}{l}\text { Annual Growth } \\
(\%)\end{array}$} \\
1950 & $(1,000)$ & \\
1951 & 52.6 & \\
1952 & 58.8 & 11.8 \\
1953 & 66.6 & 13.3 \\
1954 & 67.5 & 1.3 \\
1955 & 61.4 & -9 \\
1956 & 72.6 & 18.2 \\
1957 & 78.6 & 8.3 \\
1958 & 79.5 & 1.1 \\
1959 & 84.5 & 6.2 \\
1960 & 89.6 & 6 \\
1961 & 93.2 & 4 \\
1962 & 98.9 & 6.1 \\
1963 & 107.3 & 8.5 \\
1964 & 124.2 & 15.8 \\
1965 & 142.4 & 14.6 \\
1966 & 155.8 & 9.4 \\
1967 & 180.1 & 15.6 \\
1968 & 212.9 & 18.2 \\
1969 & 278.3 & 30.7 \\
1970 & 342.8 & 23.2 \\
\hline
\end{tabular}

Source: Brazilian Ministry of Education and Culture as cited in Souza, 1984:75. 


\section{References}

Archival and Primary Sources

ABC (Madrid) periodical. Miami, FL: University of Miami.

Arteaga, Manuel. “Hogar Catolico Universitaria.” Folder Acción Católica, Hermano Victorino. Havana: Arcebispado, 1950.

Boletim Nacional (1957). Miami: Florida International University, Department of Religion, Bidegain Papers.

Boletin de la Dirigente, Año IX, no. 103-104 (July-August 1957): Havana: Arcebispado.

Bulletin International 1948. Miami: Florida International University, Department of Religion, Bidegain Papers.

Josaphat, Frei Carlos, ed. Brasil Urgente, Sáo Paulo [Microfilm] 1, no. 48 (9 February 1964). Gainesville, Latin American Collection, University of Florida.

Correio Do Povo, Porto Alegre [Microfilm] (1959-1961). Gainesville, Latin American Collection, University of Florida.

Encyclical letters. Vatican Web site, 1922-63. Http://www.papalencyclicals.net/.

Fascisi. "Periodicals.” Il Garibaldino : Giornale Della Brigata Garibaldi (1938). Periodicals. [S.1. : Brigata Garibaldi], Wolfsonian, 1938.

Gioventù Fascista, (1935-36). Periodicals. Rome.

Legioni e Falangi: Revista d'Italia e Di Spagna (1940-43). Periodicals. Roma (Milano : Tipografia Garzanti): Unione Pubblicitá Italiana. Wolfsonian.

L'Osservatore Romano (1946-65). Florida International University, Green Library Sound and Image Resources Desk - 5th Fl. CDROM -- BX805.O82: (Vatican City : 1861 : Weekly editions).

JEC International Bulletin. 1946-1964. Miami: Florida International University, Department of Religion,. Bidegain Papers.

Memorandum, 1950. Folder Juventud Femenina y Masculina. Havana: Arcebispado, 1950.

Newsweek (1933-64).

New York Times (1953-70). New York: Florida International University, Green Library General Coll. Microfilm Area - 2nd Fl. (Government Documents). 
Partito Nazionale Fascista. Collegio Littorio Della G.I.L. : Numero 2, Partito Nazionale Fascista, Gioventù Italiana del Littorio, Roma, Foro.. Pamphlets. Rome, 1942.

Pax Romana-MIEC. "Documentos.” II Asamblea Interamericana de Universitarios Católicos. Bidegain Papers. Lima, Peru, 1946.

------. "Memoria de la II Reunion." Regional Meeting for Mexico, Central America and the Antilles. Bidegain Papers. Havana, Cuba: Editorial Echevarria, 1955.

------. "Reuniones Nacionales.” Boletín Interamericano de Información. Bidegain Papers. Havana, Cuba: Editorial Echevarria, 1957.

"Photo-History, 1 : War in Spain." Photo-History Magazine, Modern Age Book. (1937). Periodicals. New York City (Concord, N.H. : Concord Press).

La Quincena (Havana: 1955-1960). Cuban Heritage Collection. Richter Library, the University of Miami.

Oral histories and interviews

Oral history sources were used extensively for the research for this dissertation. The Center for Documentation and Scientific Information at the Pontifical Catholic University of São Paulo carried out an extensive program of oral history documentation from the late 1980s through 2000. The interviews were conducted with former members of the Brazilian university and student movements of Brazilian Catholic Action roughly thirty years after the events documented in this dissertation. All of the interviews utilized for Brazil were accessed in Portuguese on cassette tape recordings in the CEDIC center at the Pontifícia Universidade Católica in São Paulo, Brazil during the summer of 2010.

Alda Andrade, and Teófilo Ribeiro de Andrade. October 20, 1988.

Paulo de Aroucha Cotrin, January 24, 1990.

Arselina Ribeiro de Araújo. July 26, 1990.

Walter Borelli. January 26, 1990

Padre Enzo Campoes Gusso. Sept. 1989

Elisa de, Carvalho and José Juliano de Carvalho Filho. January 23, 1990.

Darcy Corazza, August 29, 1988, 
Jose Roberto Correia Soeiro and Vera Lucia Rossi Soeiro., 1997.

Carlos Alberto Libanio Christo (Frei Betto). 1997.

Frei Romeu Dale. November 13, 1987; April 13, 1993.

Frei Carlos Josaphat. March 12 and 19, 1997

José Nagamine. October 14, and November 3, 1988.

Dom Cândido Padim. May 28, 1990

Darcy Passos. October 18, 1988.

Luis Edwardo Waldemarin Wanderly. September 27, 1988.

Oral history sources for the Cuban university movement were harder to obtain. Some personal interviews were conducted by the author with several Cuban exiles living in Miami. Some additional oral history resources were consulted at the University of Miami with the Luis J. Botifoll Oral History Project during a Cuban Heritage Collection followship in the summer of $2012 .{ }^{127}$

Juan M. Clark.

Juan Manuel Salvat.

Monsignor Agustín A. Roman

Sor Hilda Alonso.

Uva de Aragó

${ }^{127}$ Video recordings are available online: http://merrick.library.miami.edu/cdm/search/collection/chc5212 
Secondary Sources

Acción Católica Cubana. "Juventudes de Acción Católica Cubana : Bodas de Plata, 19281953." San Juan, Puerto Rico: Ramallo, 1978.

Agrupación Católica Universitaria. in Lumen. Cuban Heritage Collection, University of Miami: Agrupación Católica Universitaria, Buró de Información y Propaganda, 1947.

Alonso, Arthur. Catholic Action and the Laity. Translated by Cornelius J. Crowley. St. Louis: B. Herder Book Co., 1961.

Altbach, Philip G. Student Politics in America: A Historical Analysis. New York: McGraw-Hill [1973, c1974], 1989.

-----. "Student Politics in the Third World." Higher Education 13, no. 6 (December 1984): 635-55.

------. "Students and Politics." In Students and Politics, edited by Seymour Martin Lipset. New York: Basic Books, 1967.

------. "The International Student Movement." Journal of Contemporary History 5, no. 1, Generations in Conflict (1970): 156-74.

Alvarez Junco, Jose. "The Formation of Spanish Identity and Its Adaptation to the Age of Nations." History \& Memory 13, no. 1/2 (Fall 2002): 13-36.

-----. Mater Dolorosa : La Idea De España En El Siglo XIX. Madrid: Taurus, 2001.

Alves, Marcio Moreira. A Grain of Mustard Seed: The Awakening of the Brazilian Revolution. New York City: Anchor Books., 1973.

Amato, Joseph. Mounier and Maritain: A French Catholic Understanding of the Modern World. The University of Alabama Press, 1975.

Anderson, Robin. Between Two Wars: The Story of Pope Pius XI (Achille Ratti, 19221939). Chicago: Franciscan Herald Press, 1977.

La Persecución de la Iglesia Católica en Cuba. Quito, Ecuador: Directorio Revolucionario Estudiantil de Cuba, no date.

Arendt, Hannah. On Revolution. New York,: Viking Press, 1965.

-----. The Origins of Totalitarianism. San Diego, California: Harcourt Brace Jovanovich, Inc., 1979. 
Bakewell, Peter. A History of Latin America. 2, ed. Oxford, UK: Blackwell Publishing, 2004.

Bakke, E. Wight. "Roots and Soil of Student Activism." In Students and Politics, edited by Seymour Martin Lipset. New York: Basic Books, 1967.

Bayart, Pierre. I'Action Catholique Spécialisée, Paris: A.N.S.C.A. Publications Department, 1935.

Bellah, Robert. "Max Weber and World-Denying love: A look at the Historical Sociology of Religion." Journal of the American Academy of Religion 67, no. 2 (June 1999): 277-304.

Bellin, Eva. "Faith in Politics: New Trends in the Study of Religion and Politics." World Politics 60.2 (Jan 2008).

Beozzo, José Oscar. Cristãos Na Universidade e Na Política. Petrópolis: Editora Vozes, 1984.

Berger, Peter L., ed. The Desecularization of the World: Resurgent Religion and World Politics. Grand Rapids, MI: Eerdmans Publishing Co., 1999.

------. The Sacred Canopy: Elements of a Sociological Theory of Religion. New York: Doubleday and Co., Inc., 1967.

Berger, Peter L., and Thomas Luckmann. The Social Construction of Reality: A Treatise in the Sociology of Knowledge. New York: Anchor Books, 1966.

Berkouwer, G. C. The Second Vatican Council and the New Catholicism. Grand Rapids, Mich.: Willim B. Eerdmans, 1965.

Betto, Frei. Batismo de Sangue a Luta Clandestina Contra a Ditadura Militar, Dossies Carlos Marighella e Frei Tito. Rio de Janeiro: Civilização Brasileira, 1982.

------. Fidel Y La Religion: Conversaciones Con Frei Betto Sobre El Marxismo Y La Teología De La Liberación. Bogotá, Colombia: Editorial La Oveja Negra, 1986.

Bidegain, Ana María. "From Catholic Action to Liberation Theology: The Historical Process of Laity in Latin America in the Twentieth Century." Working paper. Notre Dame, IN, 1985.

-----. "Influencia De La Guerra Fría En El Movimiento De Universitarios De Acción Católica." Unpublished paper. Bogota: Universidad Nacional de Colombia.

-----. Participacio'n y Protagonismo de las Mujeres en la Historia del Catolicismo Latinoamericano. Ciudad Autonoma de Buenos Aires: San Benito, 2009. 
Bienvenue, Louise. Quand la Jeunesse Entre en Scene: L'Action Catholique Avant la Revolution Tranquille. Montreal: Les Editions du Boreal, 2003.

Bruneau, Thomas C. The Political Transformation of the Brazilian Catholic Church. Cambridge, UK: Cambridge University Press, 1972.

------. The Church in Brazil: The Politics of Religion. Austin: The University of Texas Press, 1982.

Burdick, John. Looking for God in Brazil: The Progressive Catholic Church in Urban Brazil's Religious Arena. Berkeley: University of California Press, 1993.

Burkholder, Mark A., and Lyman L. Johnson, eds. Colonial Latin America. Oxford and New York: Oxford University Press, 2004.

Bushnell, David. The Making of Modern Colombia: A Nation in Spite of Itself. Berkeley: University of California Press, 1993.

Butler, Matthew. 'God's 'Campesinos?' Mexico's Revolutionary Church in the Countryside.” Bulletin of Latin American Research 28, no. 2 (April 2009): 20.

------. Popular Piety and Political Identity in Mexico's Cristero Rebellion : Michoacán, 1927-29. Oxford: New York: Oxford University Press, 2004.

Cardoso, Fernando Henrique, and Enzo Faletto. Dependency and Development in Latin America. Marjory Mattingly Urquidi. Berkeley: University of California Press, 1979.

Carlen, Claudia, ed. The Papal Encyclicals. Ann Arbor, Mich.: Pierian Press, 1990.

Casanova, José. Public Religions in the Modern World. Chicago, IL: The University of Chicago Press, 1994.

Chadwick, Kay, ed. Catholicism, Politics, and Society in Twentieth-Century France. Liverpool, U.K.: Liverpool University Press, 2000.

Chesnut, Andrew. 1997. Born Again in Brazil: The Pentecostal Boom and the Pathogens of Poverty. New Brunswick, NJ: Rutgers University Press.

-----. Competitive Spirits: Latin America's New Religious Economy. Oxford, UK: Oxford University Press, 2003.

Civardi, Luigi. Compendio Di Storia Dell'azione Cattolica Italiana. Roma: Coletti Editore Roma, 1956. 
Clark, Christopher and Wolfram Kaiser, eds., Culture Wars: Secular-Catholic Conflict in Nineteenth-Century Europe. Cambridge: Cambridge University Press, 2003.

Cleary, Edward L. Crisis and Change: The Church in Latin American Today. Maryknoll, NY: Orbis Books, 1985.

Clews, John. Students Unite: The IUS and Its Work. Paris: Congress for Cultural Freedom, 1952.

Cole-Arnal, Oscar. "Shaping Young Proletarians Into Militant Christians: The Pioneer Phase of the JOC in France and Quebec." Journal of Contemporary History 32, no. 4 (October 1997): 509-26.

Congar, Yves. Jalons Pour un Théologie Du Laicat. English: Lay People in the Church. Paris: Cerf, 1953.

Cornell, Richard. Youth and Communism: An Historical Analysis of International Communist Youth Movements, 1965.

Coutrot, Aline. "Youth Movements in France in The1930s." Journal of Contemporary History 5, no. 1, Generations in Conflict (1970): 23-35.

Cuplinskas, Indre. "Guns and Rosaries: The Use of Military Imagery in the FrenchCanadian Catholic Student Newspaper JEC.” Historical Studies 71 (2005): 7-28.

Cuplinskas, Indre Marija. "From Soldier to Citizen to Prophet: A Study of the Spirituality of the Jeunesse Etudiante Catholique's Newspaper 'JEC/Vie Etudiante' (1935-1964).” Ph.D. diss. Canada: University of St. Michael's College, 2006.

Curtis, David. "The French Popular Front and the Catholic Discovery of Marx.” Hull: University of Hull Press, 1997.

------. "True and False Modernity: Catholicism and Communist Marxism in 1930s France." In Catholicism, Politics, and Society in Twentieth-Century France, edited by Kay Chadwick. Liverpool, U.K.: Liverpool University Press, 2000.

Da Veiga, Laura. "Reform of the Brazilian University: The University and the Question of Hegemony (1954-1968).” Diss. Palo Alto, California: Stanford University, 1981.

Dansette, Adrien, and James A. Corbett. "The Rejuvenation of French Politics: Marc Sangnier's Sillon.” The Review of Politics 15, no. 1 (January 1953): 34-52.

De Jesus, Carolina Maria. Child of the Dark. Quarto de Despejo [1960]. David St. Clair. New York: Mentor Books, 1962. 
De Kadt, Emanuel. "Religion, the Church, and Social Change in Brazil." In The Politics of Conformity in Latin America, edited by Claudio. Veliz. London and Oxford: Oxford University Press, 1970.

De La Bedoyere, Michael. The Cardijn Story. Milwaukee, Wisconsin: The Bruce Publishing Co., 1958.

Della Cava, Ralph. "Catholicism And Society In Twentieth-Century Brazil." Latin American Research Review 11, no. 2 (1976): 7-50.

Delmaire, Danielle. "Antisémitisme Des Catholiques Au Vingtième Siècle: De la Revendication Au Refus." In Catholicism, Politics, and Society in TwentiethCentury France, edited by Kay Chadwick. Liverpool, U.K.: Liverpool University Press, 2000.

Dewart, Leslie. Christianity and Revolution, the lesson of Cuba. New York: Herder and Herder, 1963.

Diaz, J, comp. Victorino: Hermano de la Salle: Fundador de la Juventud Catolica. Hermanos de la Salle, nd.

Downs, Laura Lee. Childhood in the Promised Land: Working-Class Movements and the Colonies de Vacances in France, 1880-1960. Durham and London: Duke University Press, 2002.

Eakin, Marshall C. The History Of Latin America: Collision of Cultures. New York: Palgrave Macmillan Publishing Co., Inc., 2007.

Eisenstadt, S. N. "Contemporary Student Rebellions: Intellectual Rebellion and Generational Conflict.” Acta Sociologica 14, no. 3 (1971): 169-82.

Emmerson, Donald K. Students and Politics in Developing Nations. London: Pall Mall Press, 1968.

Errazuriz, Manuel Larrain Mons. La Hora de la Acción Católica. Santiago de Chile: Editorial del Pacifico, 1956.

Farber, Samuel. The Origins of the Cuban Revolution Reconsidered. Chapel Hill: University of North Carolina Press, 2006.

Feldman, Christian. Pope John XXIII: A Spiritual Biography. Translated by Peter Heinegg. New York: Crossroad Publishing Company, 2000.

Fernández Santalices, Manuel. Cuba: Catolicismo y Sociedad en un Siglo de Independencia. Caracas, Venezuela: ODCA, 1996. 
Fernández Soneira, Teresa. Con la Estrella y la Cruz : Historia de la Federación de la Juventudes de Acción Católica Cubana. Miami: Ediciones Universal, 2002.

Fogarty, Michael P. Christian Democracy in Western Europe, 1880-1953. London: Routledge \& Kegan Paul Ltd, 1957.

Freeden, Michael. Ideology, A Very Short Introduction. Oxford: Oxford University Press, 2003.

Frie Betto. Batismo de Sangue a Luta Clandestina Contra a Ditadura Militar, Dossies Carlos Marighella e Frei Tito. Rio de Janeiro: Civilização Brasileira, 1982, 1982.

------. Cartas Da Prisao. Rio de Janeiro, RJ: Editora Civilização Brasileira, 1977.

Freire, Paulo. Pedagogy of the Oppressed. New York: Continuum, 2000.

Furtado, Celso. The Economic Growth of Brazil. Originally published in 1959 in Portuguese as Formação Econômica do Brasil. Cambridge, England: Cambridge University Press, 1965.

Gauvreau, Michael. The Catholic Origins of Quebec's Quiet Revolution, 1931-1970. Quebec: McGill-Queens University Press, 2005.

Gerth, H.H., and C Wright Mills, eds. From Max Weber: Essays in Sociology. Oxford: Oxford University Press, 1958.

Godin, H., and G. Guerin. La France, Pays de Mission? Paris: Cerf, 1943.

Gomez Treto, Raúl. La Iglesia Católica Durante la Construcción de Socialismo en Cuba. San José, Costa Rica:: DEI: Departamento Ecuménico de Investigaciones, 1987.

Gramsci, Antonio. Selections from the Prison Notebooks. Reprinted in 2005. New York: International Publishers, 1971.

Greeley, Andrew M. The Catholic Revolution : New Wine, Old Wineskins, and the Second Vatican Council. Berkeley: University of California Press, 2004.

Griffin, Roger, ed. Fascism. Oxford: New York: Oxford University Press, 1995.

Haber, Stephen. How Latin America Fell Behind. Stanford: Stanford University Press, 1997.

Halperín Donghi, Tulio. "'Dependency Theory" and Latin American Historiography." Latin American Research Review, 17, no. 1 (1982): 115-30.

Hanson, Eric O. The Catholic Church in World Politics. Princeton: Princeton University Press, 1987. 
Hennessy, Alistair. "University Students in National Politics." In The Politics of Conformity in Latin America, edited by Claudio Veliz. London and Oxford: Oxford University Press, 1970.

Holbrook, Joseph. "Church, State and Political Culture in Brazil and Colombia." Masters thesis. Miami: Florida International University, 2006.

Horn, Gerd-Rainer. Western European Liberation Theology: The First Wave (19241959). Oxford, New York: Oxford University Press, 2008.

Horn, Gerd-Rainer, and Emmanuel Gerard. Left Catholicism 1943-1955: Catholics and Society in Western Europe at the Point of Liberation, 1943 - 1955. Brussels: Leuven Univ. Press, 2001.

Hughes, Emmet John. Report from Spain. Port Washington, N.Y.: Kennikat Press, 1947.

Hughes, Everett C. French Canada in Transition. Quebec: Oxford University Press, 2005.

Ianni, Octavio. O Labirinto Latino Americano. Petrópolis: Editora Vozes, 1995.

Jedin, Hubert, Roger Aubert, and John Dolan. The Church Between Revolution \& Restoration. Translated by Peter Becker. New York: Crossroad, 1981.

J.O.C. Comité national. Cardijn, Père de la J.O.C. Mondiale. Montrèal: Éditions ouvrières, 1947.

Jordan, David C. Revolutionary Cuba and the End of the Cold War. Lanham, MD: University Press of America, 1993.

Kellner, Douglas. "Review of Ideology and Modern Culture by John Thomspon." The American Journal of Sociology 97, no. 4 (January 1992): 1184-86.

Kelly, Michael. "Catholicism and the Left in Twentieth-Century France." In Catholicism, Politics, and Society in Twentieth-Century France, edited by Kay Chadwick. Liverpool, U.K.: Liverpool University Press, 2000.

Kirk, John M. Between God and the Party: Religion and Politics in Revolutionary Cuba. Tampa, FL: University of South Florida Press, 1989.

Kurt H. Wolff. From Karl Mannheim. With an introduction by Volker Meja and David Kettler. New Brunwick, N.J.: Transaction Publishers, 1993.

Küng, Hans. Structures of the Church. London: Burns \& Oates, 1965.

Lakeland, Paul. The Liberation of the Laity: In Search of an Accountable Church. New York: Continuum, 2003. 
Lebret, L. J. Homenaje a L. J. Lebret. Lima: Editorial Universo, 1969.

Levine, Daniel H. Religion and Politics in Latin America: The Catholic Church in Venezuela and Colombia. Princeton: Princeton University Press, 1981.

Levine, Robert M. Father of the Poor? Vargas and His Era. Cambridge: Cambridge University Press, 1998.

Lipset, Seymour Martin. Students and Politics. New York: Basic Books, 1967.

------. "University Students and Politics in Underdeveloped Countries." In Students and Politics, edited by Seymour Martin Lipset. New York: Basic Books, 1967.

Löwy, Michael. The War of the Gods: Religion and Politics in Latin America. London: Verso, 1996.

MacLean, Iain S. Reconciliation, Nations and Churches in Latin America. Aldershot: Ashgate, 2006.

Mainwaring, Scott. The Catholic Church and Politics in Brazil, 1916-1985. Stanford, CA: Stanford University Press, 1986.

------. “A JOC e o Surgimento Da Igreja Na Base (1958-1970).” Revista Eclesiástica Brasileira 43, no. 169 (March 1983): 29-92.

Maritain, Jacques. Integral Humanism; Temporal and Spiritual Problems of a New Christendom. Translated by Joseph W. Evans. Notre Dame: University of Notre Dame Press, 1975.

------. True Humanism. Translated by Margot Adamson. New York: Charles Scribner's Sons, 1938.

Martin, David. A General Theory of Secularization. New York: Harper \& Row, 1978.

-----. Tongues of Fire : The Explosion of Protestantism in Latin America. Cambridge, MA: Blackwell, 1990.

Maynes, Mary Jo. "Age as a Category of Historical Analysis. History, Agency, and Narratives of Childhood." The Journal of the History of Childhood and Youth 1, no. 1 (January 2008): 114-24.

Melloni, Albert, ed. 'Movements' in the Church. London: SCM Press, 2003.

Mesa-Lago, Carmelo. Revolutionary Change in Cuba. Pittsburg, Pa.: The University of Pittsburgh Press, 1971. 
Meyer, John W., and Richard Rubinson. "Structural Determinants of Student Political Activity: A Comparative Interpretation.” Sociology of Education 45, no. 1 (Winter 1972): 23-46.

Mintz, Steven. Huck's Raft: A History of American Childhood. London and Cambridge: Harvard University Press, 2004.

------. "Reflections on Age as a Category of Historical Analysis." The Journal of the History of Childhood and Youth 1, no. 1 (January 2008): 91-94.

Misner, Paul. "Catholic Labor and Catholic Action: The Italian Context of Quadragesimo Anno." The Catholic Historical Review 90, no. 4 (October 2004): 650.

------. Social Catholicism in Europe: From the Onset of Industrialization to the First World War. New York: Crossroad, 1991.

Monteiro Garcia, Feliciano. La Acción Católica y el Franquismo. Auge y Crisis de la Acción Católica Especializada. Madrid: UNED Ediciones, 2000.

Morcillo, Aurora G. True Catholic Womanhood, Gender Ideology in Franco's Spain. DeKalb: Northern Illinois University Press, 2000.

Mounier, Emmanuel. Personalism. Translated by Philip Mairet. Notre Dame: University of Notre Dame Press, 2005.

------. Personalist Manifesto. London ; New York: Longmans, Green, 1938.

------. Sombras de Mêdo Sôbre o Século XX. Translated from La petite peur du XXe siècle (1948). Rio de Janeiro: Agir Editora, 1959.

Ortiz, Fernando. Cuban Counterpoint: Tobacco and Sugar. London: Duke University Press, 1995.

Paiva, Angela Randolpho. Católico, Protestante, Cidadão : Uma Comparação Entre Brasil e Estados Unidos. Belo Horizonte, Brazil: Editora UFMG, 2003.

Payne, Stanley G. Spanish Catholicism: An Historical Overview. Madison: University of Wisconsin Press, 1984.

Pelletier, Gerard. Years of Impatience: 1950-1960. Alan Brown. Toronto: Methuen \& Co., Ltd, 1984.

Peña, Milagros. "Liberation Theology in Peru: An Analysis of the Role of Intellectuals in Social Movements." Journal for the Scientific Study of Religion 33, no. 1 (March 1994): 34-45. 
Petito, Fabio, and Pavlos Hatzopoulous. Religion in International Relations: The Return from Exile. New York: Palgrave MacMillan, 2003.

Pérez, Jr., Louis A. Cuba: Between Reform \& Revolution. Oxford: Oxford University Press, 1995.

------. On Becoming Cuban: Identity, Nationality, \& Culture. New York: Ecco Press, 1999.

Pius XII. The Lay Apostolate, Its Need Today: An Address of Pope Pius XII to the World Congress of the Lay Apostolate. United States Catholic Conference. Washington, DC: National Catholic Welfare Conference, October 14, 1951.

Pochon, Roger, and Ramon Sugranyes de Franch. "Pax Romana, 1921-1961: Pax Romana Down the Years.” Unpublished manuscript. Friburg, Switzerland, 1961. Http://www.icmica-miic.org/en/.

Poggi, Gianfranco. Catholic Action in Italy. Stanford: Stanford University Press, 1967.

Portuondo, Yolanda. Guillermo Sardiñas, Sacerdote Commandante - Testimonio. La Habana: Editorial Cultura Popular, 1988.

Poulat, Emile. "The Great Adventure of the Catholic Movement in France." In 'Movements' in the Church, edited by Albert Melloni. London: SCM Press, 2003.

Poyo, Gerald E. Cuban Catholics in the United States, 1960-1980 : Exile and Integration. Latino Perspectives Series. Notre Dame: University of Notre Dame Press, 2007.

Rhodes, Anthony. The Vatican in the Age of the Dictators, 1922-1945. London: Hodder and Stoughton, 1973.

Ricoeur, Paul. History and Truth. Translated by Charles A. Kelbley. Evanston, IL: Northwestern University Press, 1965.

Roberts, Colin. "Secularisation and the (Re)Formulation of French Catholic Identity." In Catholicism, Politics, and Society in Twentieth-Century France, edited by Kay Chadwick. Liverpool: Liverpool University Press, 2000.

Safford, Frank, and Marco Palacios. Colombia: Fragmented Land, Divided Society. Oxford: Oxford University Press, 2002.

Scott, James C. Weapons of the Weak: Everyday Forms of Peasant Resistance. Reprint ed. New Haven and London: Yale University Press, 1987.

La Voz de la Iglesia en Cuba, 100 Documentos Episcopales. México, D.F.: Conferencia de Obispos Católicos de Cuba, 1995. 
Serbin, Kenneth P. "Church-State Reciprocity in Contemporary Brazil: The Convening of the International Eucharistic Congress of 1955 in Rio de Janeiro." The Hispanic American Historical Review 76, no. 4 (November 1996): 721-51.

------. Needs of the Heart: A Social and Cultural History of Brazil's Clergy and Seminaries. Notre Dame: University of Notre Dame Press, 2006.

-----. Secret Dialogues: Church-State Relations, Torture, and Social Justice in Authoritarian Brazil. Pittsburgh, PA: University of Pittsburgh Press, 2000.

Silvert, K. H. "The University Student." In Continuity and Change in Latin America, edited by John J. Johnson, 206-27. Stanford: Stanford University Press, 1964.

Simon, Roger. Gramsci's Political Thought, An Introduction. Reprinted in 2005. London: Lawrence \& Wishart, 1982.

Skidmore, Thomas E. Brazil: Five Centuries of Change. Oxford: Oxford University Press, 1999.

------. Politics in Brazil 1930-1964 : An Experiment in Democracy. Oxford: Oxford University Press, 1967.

-----. The Politics of Military Rule in Brazil 1964-85. Oxford: Oxford University Press, 1988.

Smith, Christian. The Emergence of Liberation Theology: Radical Religion and Social Movement Theory. Chicago: The University of Chicago Press, 1991.

Souza, Luiz Alberto Gómez de. A JUC: Os Estudantes Católicos e a Política. Petrópolis: Vozes, 1984.

Souza, Luiz Alberto Gómez de. Do Vaticano II a Um Novo Concílio? O Olhar de Um Cristão Sobre a Igreja. São Paulo: Edições Loyola, 2004.

Stein, Stanley, and Barbara H. Stein. The Colonial Heritage of Latin America: Essays on Economic Dependence in Perspective. Oxford: Oxford University Press, 1970.

Stern, Steve J. "Feudalism, Capitalism, and the World-System in the Perspective of Latin America and the Caribbean." The American Historical Review 93, no. 4 (October 1988): 829-72.

Strauss, William, and Neil Howe. Generations: The History of America's Future, 1584 to 2069. New York: William Morrow and Co., 1991.

Suchlicki, Jaime. University Students and Revolution in Cuba, 1920-1968. Coral Gables: University of Miami Press, 1969. 
Susser, Bernard. Political Ideology in the Modern World. Boston \& London: Allyn and Bacon, Inc., 1995.

Szulc, Tad. Fidel: A Critical Portrait. New York: William Morrow and Company, 1986.

The Benedictine Monks of Solesmes, comp. and ed. The Lay Apostolate, Papal Teachings. Boston: Daughters of St. Paul, 1961.

Therry, Leonard D. "Dominant Power Components in the Brazilian University Student Movement Prior to April, 1964." Journal of Inter-American Studies 7, no. 1 (January 1965): 27-48.

Thompson, E. P. "The Moral Economy of the English Crowd in the Eighteenth Century." Past and Present, no. 50 (February 1971): 76-136.

Thompson, John B. Ideology and the Modern World. Berkeley \& Los Angeles: University of California Press, 1991.

------. Studies in the Theory of Ideology. Berkeley \& Los Angeles: University of California Press, 1984.

Thompson, Michael, Richard Ellis, and Aaron Wildavsky. Cultural Theory. Boulder: Westview Press, 1990.

Thorp, Rosemary. Progress, Poverty and Exclusion: An Economic History of Latin America in the 20th Century. Washington: Johns Hopkins University Press, 1998.

Troeltsch, Ernst. The Social Teaching of the Christian Churches. Vol. 1. Translated by Olive Wyon. Louisville, London: Westminster John Knox Press, 1931, reprint 1992.

-----. The Social Teaching of the Christian Churches. Vol. 2. Translated by Olive Wyon. Louisville, London: Westminster John Knox Press, 1931, reprint 1992.

Tucker, Robert C. The Marx-Engles Reader. New York: W. W. Norton \& Company, 1978.

Vallier, Ivan. Catholicism, Social Control, and Modernization in Latin America. Englewood Cliffs, NJ: Prentice, 1970.

van Akin, Mark J. "University Reform Before Cordóba.” The Hispanic American Historical Review 51, no. 3 (August 1971): 447-62.

Vásquez, Manuel A. The Brazilian Popular Church and the Crisis of Modernity. Cambridge: Cambridge University Press, 1998. 
Walker, Kenneth N. "A Comparison of University Reform Movements in Argentina and Colombia." Comparative Education Review 10, no. 2, Special Issue on Student Politics (June 1966): 257-72.

Wallerstein, Immanuel. The Modern World System: Capitalist Agriculture and the Origins of the European World Economy in the Sixteenth Century. New York: Academic Press, 1974.

Weber, Max. "Politics as a Vocation." In The Vocation Lectures, edited by David Owen and Tracy B. Strong, translated by Rodney Livingston. Indianapolis: Hackett Publishing Co., 2004.

------. The Protestant Ethic and the Spirit of Capitalism. Translated by Talcott Parsons. New York: Charles Scribner's Sons, 1958.

------. The Sociology of Religion. Originally published in 1922 as Religionssoziologie from Wirtschaft and Gesellschaft. Translated by Ephraim Fischoff. Boston: Beacon Press, 4th ed. 1991.

White, Mark J. Missiles in Cuba: Kennedy, Khrushchev, Castro and the 1962 Crisis. Chicago: Ivan R. Dee, Inc., 1997.

Whitney, Susan B. Mobilizing Youth: Communists and Catholics in Interwar France. Durham: Duke University Press, 2009.

Whyte, John Henry. Catholics in Western Democracies: A Study in Political Behaviour. Dublin: Gill and Macmillan, 1981.

Wilde, Alexander. Conversaciones de Caballeros: La Quiebra de la Democracia en Colombia. Bogotá: Ediciones Tercer Mundo, 1982.

Wohl, Robert. The Generation of 1914. Cambridge, Mass.: Harvard University Press, 1979.

Wright, Gordon. France in Modern Times. 4th ed. New York \& London: W. W. Norton \& Company, 1981. 
VITA

\section{JOSEPH HOLBROOK}

$\begin{array}{ll}\text { April 28, } 1951 & \text { Born, Columbus, Ohio } \\ 1989 & \begin{array}{l}\text { B.A., Modern Languages. } \\ \text { Ohio State University } \\ \text { Columbus, Ohio }\end{array} \\ \text { 1989-1999 } & \text { Pastor, Miami Florida } \\ 2000-2004 & \begin{array}{l}\text { Director/founder } \\ \text { NGO, Miami, Florida }\end{array} \\ 2004-2005 & \begin{array}{l}\text { M.A., Latin American and Caribbean } \\ \text { Studies } \\ \text { Florida International University } \\ \text { Miami, Florida }\end{array} \\ 2006-2013 & \begin{array}{l}\text { Doctorate in History } \\ \text { Florida International University } \\ \text { Miami, Florida }\end{array}\end{array}$

PUBLICATIONS AND PRESENTATIONS

Transnational Catholic Student Movements, 1946 to 1966. The Atlantic Millennium, A Graduate Journal on Atlantic Civilization 10 (2011):2335.

The Catholic Church in Cuba, 1959-62: The clash of ideologies. International Journal of Cuba Studies 2, no. 3-4 (Autumn/Winter 2010):264-75.

"Student Movements in Brazil and Cuba." Presented at the Miami-Dade Council for the Social Studies (MDCSS) Teachers Conference on November 6, 2012.

"Transnational influences on the Catholic Church in Cuba, 1946 - 1962." Paper presented at the Cuban Research Institute, FIU in February, 2010.

"The Catholic Church in Cuba, 1959 - 1962: The Clash of Ideologies." Paper presented at the American Historical Society, New York in January, 2009. 